DOE /NASA CONTRACTOR REPORT

DOE/NASA CR-150784

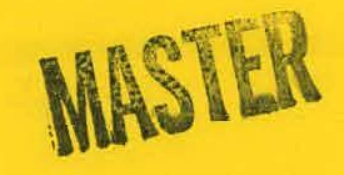

\title{
CERTIFICATION AND VERIFICATION FOR CALMAC FLAT PLATE SOLAR COLLECTOR
}

Prepared from documents furnished by

Calmac Manufacturing Company

150 S. Van Brunt Street

Englewood, New Jersey 07631

Under Contract NAS8-32253 with

National Aeronautics and Space Administration

George C. Marshall Space Flight Center, Alabama 35812

For the U. S. Department of Energy

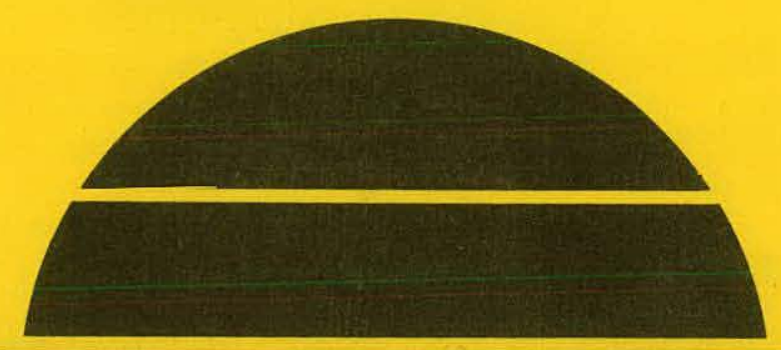

\section{U.S. Department of Energy}

Solar Energy 


\section{DISCLAIMER}

This report was prepared as an account of work sponsored by an agency of the United States Government. Neither the United States Government nor any agency Thereof, nor any of their employees, makes any warranty, express or implied, or assumes any legal liability or responsibility for the accuracy, completeness, or usefulness of any information, apparatus, product, or process disclosed, or represents that its use would not infringe privately owned rights. Reference herein to any specific commercial product, process, or service by trade name, trademark, manufacturer, or otherwise does not necessarily constitute or imply its endorsement, recommendation, or favoring by the United States Government or any agency thereof. The views and opinions of authors expressed herein do not necessarily state or reflect those of the United States Government or any agency thereof. 


\section{DISCLAIMER}

Portions of this document may be illegible in electronic image products. Images are produced from the best available original document. 
This report was prepared to document work sponsored by the United States Government. Nelther the United States nor 1ts agents the United States Department of Energy, the Unfted States National Aeroraut1cs and Space Administration, nor any federal employees, nor any of their contractors, subcontractors or the1r employees, make any warranty, express or implied, or assume any legal liability or responsibility for the accuracy, completeness, or usefulness of any information, apparatus, product or process disclosed, or represent that its use would not Infinge privately owned rights. 


\begin{tabular}{|c|c|}
\hline $\begin{array}{l}\text { 1. REPORT NO. } \\
\text { DOE/NASA CR-150784 }\end{array}$ & \multirow{2}{*}{$\begin{array}{l}\text { 3. RECIPIENT'S CATALOG NO. } \\
\text { 5. REPORT DATE } \\
\text { September } 1978\end{array}$} \\
\hline \multirow{2}{*}{$\begin{array}{l}\text { 4. TITLE AND SUBTITLE } \\
\text { Certification and Verification for Calmac Flat Plate Solar } \\
\text { Collector }\end{array}$} & \\
\hline & 6. PERFORMING ORGANIZATION CCIDE \\
\hline 7. AUTHOR(S) & $\begin{array}{l}\text { B. PERFORMING ORGANIZATION REPORT \# } \\
77 \text { S } 1111\end{array}$ \\
\hline \multirow{3}{*}{$\begin{array}{l}\text { 9. PERFORMING ORGANIZATION NAME AND ADDRESS } \\
\text { Calmac Manufacturing Company } \\
150 \mathrm{~S} \text {. Van Brunt Street } \\
\text { Englewood, New Jersey } 07631\end{array}$} & 10. WORK UNIT NO. \\
\hline & $\begin{array}{l}\text { 11. CONTRACT OR GRANT NO. } \\
\text { NAS8-32253 }\end{array}$ \\
\hline & \multirow{2}{*}{$\begin{array}{l}\text { 13. TYPE OF REPORT \& PERIOD COVERED } \\
\text { Contractor Report }\end{array}$} \\
\hline $\begin{array}{l}\text { 12. SPONSORING AGENCY NAME AND ADORESS } \\
\text { National Aeronautics and Space Administration }\end{array}$ & \\
\hline Washington, D. C. 20546 & 14. SPONSORING AGENCY CODE \\
\hline
\end{tabular}

This work was done under the technical management of Mr. John Caudle, George C. Marshall Space Flight Center, Alabama.

16. ABSTRACT

This document contains information used in the certification and verification of the Calmac Flat Plate Collector. Contained are such items as test procedures and results, information on materials used, Installation, Operation, and Maintenance Manuals, and other information pertaining to the verification and certification.

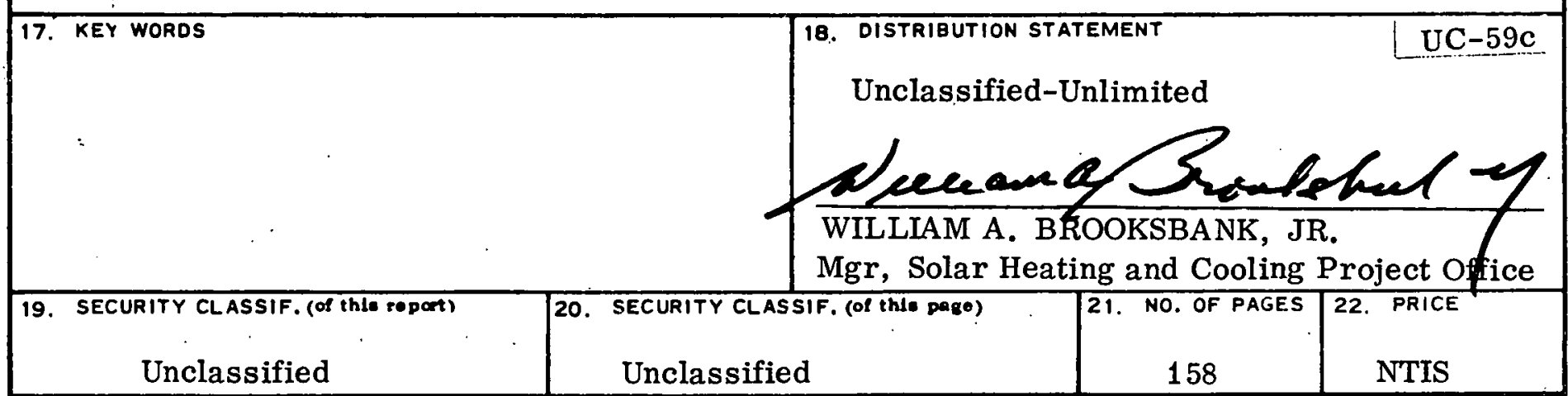


THIS PAGE

\section{WAS INTENTIONALLY}

LEFT BLANK 
TABLE OF CONTENTS

Page

Section $1 \quad$ Certification Report

Section 2 Verification Report

Appendix A Materials

Appendix B Collector Installation, Operation \& Service Manual

Appendix C Field-Assembled Solar Collector

Installation, Operation \& Service Manual

NOTICE MN ONLY

PORTIONS OF THIS REPORT ARE ILLEGIBLE. It has been ressoduced from the best available cspy to permit the broadest possible avail ability.

This report was prepared as an account of work sponsored by the United States Govermment. Neither the United States nor the United States Department of Energy, nor any of their employees, nor any of their contractors, subcontractors, of their employees, makes any warranty, express or implied, of assumes any legal liability or responsibility for the accuracy, completeness or usefulness of any information, apparatus, product or
process disclosed, or represents that its use would not infringe privately owned rights. 


\author{
SECTION 1 \\ CERTIFICATION REPORT \\ TO \\ MARSHALL SPACE FLIGHT CENTER \\ FOR
}

NATIONAL AERONAUTICS AND SPACE ADMINISTRATION

THE SUNMAT LIQUID FLAT PLATE COLLECTOR

CALMAC Mfg. Corp. $150 \mathrm{~S}$. Van Brunt St. Englewood, NJ 07631 
The SUNMAT's compliance with the IPC was reviewed and confirmed by Engineering Testing Laboratories, and their analysis is included with this report. The report also includes test results from Desert Sunshine Exposure Tests confirming the SUNMAT's compliance with thermal perforance and efficiency specifications.

\footnotetext{
$\frac{\text { Whan M. Acreturg, ViP, Pinget Manegen }}{\text { CALMAC Manufacturing Corp. }}$ $4 / 20 / 78$
} 


\section{DESERT SUNSHINE EXPOSURE TESTS, INC. \\ We Test Anything Under the Sun \\ BOX $185 \cdot$ BLACK CANYON STAGE \\ PHOENIX, ARIZONA 85020 \\ (602) 465.7525}

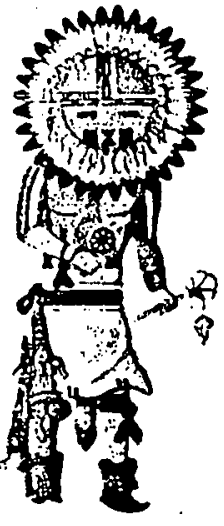

TAWA.

THE SUN KACHINA
April 14, 1978

Mr. John Armstrong

CAIMAC MANUFACTURING CORPORATION

150 South Van Brunt Street

Englewood, New Jexsey 07631

Subject: Test Sequence of Sunmat Collector to Conform to 1975 IPC and HUD/HWI

Dear Mr. Armstrong:

Desert Sunshine Exposure Tests, Inc. performed an ASHRAE 93-77 thermal performance, a 30-day stagnation and a thermal performance retest in accordance with the HUD requirements for the Hot Water Initiative. The data and results of these tests are presented in DSET Report No. 77SIIIIA. ASHRAE 93-77 is the test standard that is generally accepted, industry-wise, as the standard for thermal performance testing of solar collectors. On the basis of the DSET tests, the collector is judged to meet the HUD/HWI requirement that no more than a 10 percent change be observed for the values of $F_{R} \alpha \tau$ (the

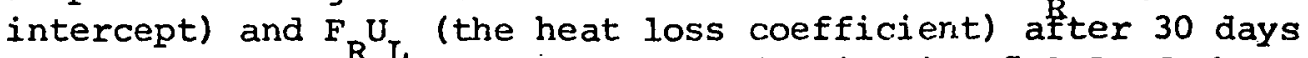
of stagnation. Thus, paragraph $b$ of Criterion 5.1 .1 of the 1975 Interim Performance Criteria is also judged to be met.

Other criteria applicable to the 1975 IPC were evaluated by Engineers Testing Laboratories, Inc. Their letter report is attached to this summary.

Respectfully submitted,

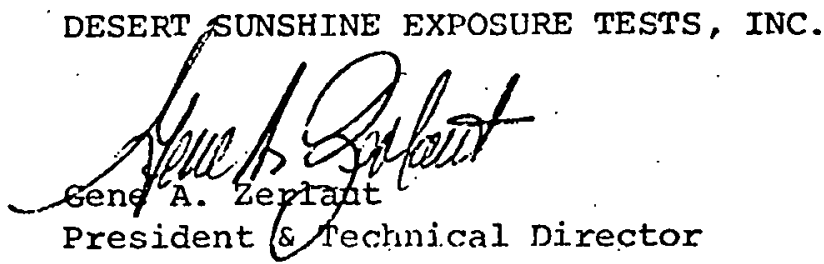

GAZ: If

Enclosures 
Report No. 77S1111

DSET No. 184715

SOLAR COLLECTOR PERFORMANCE TEST

For:

Mr. Cal MacCracken

President

CALMAC MANUFACTURING CORP. 150 South Van Brunt Street

Englewood, New Jersey 07631

From:

Desert Sunshine Exposure Tests, Inc. Box 185 Black Canyon Stage

Phoenix, Arizona 85020

By:

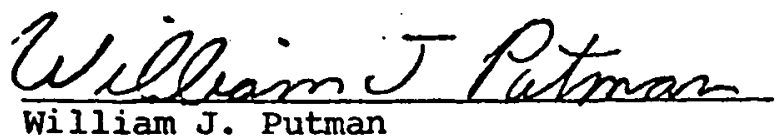
William J. Putman Research Engineer

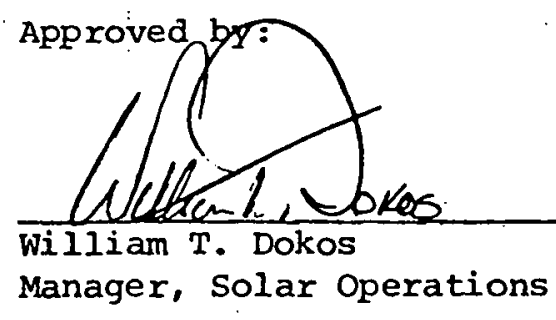


This test report contains only findings and results arrived at after employing the specific test procedures and standards listed. It does not constitute a recommendation for, or endorsement of, or certification of the product or material tested. Desert Sunshine Exposure Tests, Inc. makes no warranty, expreised or implied, except that the analysis has been made, and a report prepared, based upon the sample or samples furnished by the client. Any extrapolation of data from the sample or samples relating to the batch or lot from which it was obtained may not correlate and should be interpreted accordingly with extreme caution. We assume no responsibility for variations in qualj.ty, composition, appearance, performance, or other feature of similar subject matter produced by persons or under conditions over which we have no control. 
INTRODUCTION

A program has been instituted by the United States Department of Housing and Urban Development to encourage homeowners to install solar hot water systems. This program, commonly referred to as the HUD solar Hot water Initiative (SHWI), requires manufacturers of solar equipment, who wish to qualify their products for this program, to meet certification requirements set forth by the HUD Intermediate Standards for Solar Domestic Hot Water Systems/HUD Initiative.

Desert Sunshine Exposure Tests, Inc. (DSET) has been approved to perform the "Thermal stability" test which is part of the certification requirements. DEET, Inc. conducts the thermal stability test in accordance with the procedure outlined by the HUD Intermediate Minimim Property Standards Supplement (ILPS 4930.2, Sec. 5-515-2.1.2).

The thermal stability test consists of three parts:

A. Initial ASHRAE 93-77 thermal performance test.

B. 30-day stagnation exposure test.

c. Final modified ASHRAE 93-77.

\section{A. INITIAL ASKRAE 93-77}

The initial ASHRAE 93-77 thermal performance test consists of four separate parts: (1) Preconditioning, (2) Determination of the collector's time constant, (3) Instantaneous efficiency performance tests, and (4) Determination of the incident angle modifier for the collector.

\section{Preconditioning}

In preparation for the preconditioning test, the collector is filled with water and the inlet sealed. The panel is then placed in a nonoperational stagnation mode in which the water is allowed to evapoxate out during exposure. The collector is exposed for three days in a stagnation mode during which the cumulative incident solar radiation in the plane of the collector is at least $1500 \mathrm{BTU} / \mathrm{ft}^{2} / \mathrm{day}$. 


\section{Time Constant}

The time constant is an indication of the transient response of the collector to a step change in insolation and is utilized to determine the proper data intervals for the instantaneous efficiency tests.

The test to determine the "Time constant" is performed in accordance with ASHRAE 93-77 (Section 8.3.1, Method (1)). A.SHRAE 93-77 defines the time constant as the time required for the outlet fluid temperature to attain 63.2 percent of its steady state value after the collector has been shaded with a cover to provide a step change in insolation.

\section{Instantaneous Efficiency Test}

The instantaneous efficiency tests are conducted to determine the efficiency of the collector as a function of the incident solar radiation, ambient temperature, and collector fluid inlet temperature.

ASHRAE 93-77 defines the solar collector efficiency as the amount of useful energy extracted from the collector divided by the amount of incident solar energy intercepted by the gross area of the collector.

At least sixteen (16) efficiency "data points" are abtained during the test in order that a governing "efficiency curve" can be generated.

All instantaneous efficiency testing is conducted in accordance with ASHRAE 93-77 and DSET Specification 75-SE2, appended herewith, utilizing a sun-tracking altazimuth mount which maintains the collector at normal incidence during the test periods.

Analysis of the effeiciency data is performed by employing a 2nd order least squares polynomial resulting in an efficiency equation given as a function of the inlet parameter, $\left(T_{i}-T_{a} / q_{i}\right)$.

Procedures and instrumentation employed for this test are described in DSET Specification 75-SE2 with the following exception: standard pressure gauges were used for pressure measurements. The pressure gauges used were not considered highly accurate; therefore, caution is advised in forming any conclusions based upon these measurements.

\section{Incident Angle Modifier}

in order to predict the collector efficiency at incident angles other than zero, the incident angle modifier, $\mathrm{K}_{\alpha \tau^{\prime}}$ is determined for the collector... The incident angle modifier is a factor used to modify the performance 
curve (determined at normal incidence) to account for the changes in performance due to the sun's incident angle.

The test is conducted by adjusting the altazimuth mount such that incident angles to the collector are $30^{\circ}, 45^{\circ}$, and $60^{\circ}$. Data are taken in each of the incident angle positions and the efficiency is calculated. For an incident angle of $0^{\circ}$, data from the instantaneous efficiency test are used.

The data from the incident angle modifier test are analyzed to determine the equation that describes $k_{\alpha \tau}$ as a function of $\frac{1}{\cos \theta}-1$, where $\theta$ is the incident angle of the sun.

\section{B. 30-DAY STAGNATION EXPOSURE TEST}

The 30-day stagnation exposure test is designed to identify potential problems associated with the collector's materials and/or construction. The test is conducted by the method outlined in the HUD Intermediate Minimum Property Standards Supplement (MPS 4930.2, Sec. 5-515-2.1.2 A-D).

Pre-exposure preparation for the collector consists of filling the collector with tap water and sealing the inlet. A pressure relief valve is placed on the outlet for those collectors that operate under pressure. The relief valve is set to a value within 10 percent of the manufactorer's recomended maximum value.

The exposure test requires the collector to undergo 30 days of cumulative exposure to a minimum daily incident solar radiation ot at least 1500 $\mathrm{BTU} / \mathrm{ft}^{2} /$ day as measured in the plane of the collector aperture. During this test the collector is exposed for at least one consecutive four-hour period with a minimum flux of $300 \mathrm{BTU} / \mathrm{ft}^{2} / \mathrm{hr}$ after "boilout" of the water has occurred.

Appropriate data records, such as insolation, ambient temperature, wind velocity, and precipitation are obtained for each day of stagnation. During the 300. BTU/ft ${ }^{2} \mathrm{hr}$ period, these data are recorded every 30 minutes. Obser vations of the physical appearance of the collector are recorded during weekly visual inspections. 


\section{c. FINAL ASHRAE 93-77}

The final modified ASHRAE 93-77 test differs from the initial ASHRAE 93-77 test in that the preconditioning, determination of the time constant, and the determination of the incident angle modifier are eliminated.

The final test requires a shortened instantaneous efficiency test. This shortened test requires 12 efficiency "data points" compared with a minimum of 16 from the first test.

An efficiency curve is generated from these data and the $F_{R} \alpha \tau$ and $F_{R} U_{L}$ values are found for the collector.

A composite graph is provided in the following report which shows the instantaneous efficiency data and analysis results for both initial and final tests.

\section{SPECIAL TEST}

A special test is also reported along with the results of the final ASHRAE 93-77 test. Four instantaneous efficiency points were taken at approximately the same collector fluid inlet temperatures with the glazing of the collector removed. This test was performed to determine indirectly the losses through the cover at the collector under the imposed operating parameters. 


\section{EXPERIMENTAL}

This section of the report presents the data and results of the thermal performance and stagnation test performed on the Calmac Manufacturing Corporation's "Sunmat" solar collector:

The collector's design incorporated the use of plastic absorber tubes connected to a copper header, with a single plastic cover.

A. INITIAL ASHRAE 93-77

The data and results for this test have been previously reported in Report No. 77silll of January 27, 1978. 
B. 30-DAY STAGNATION EXPOSURE TEST

Fifty (50) days were required to achieve 30 days of exposure representing $1500 \mathrm{BTU} / \mathrm{ft}^{2}$. day in the plane of the collector. This exposure period was unusually extended due to uncharacteristic winter weather experienced at the test site. All relevant data, including visual inspection information, are presented in the following tables (Tables 1 and 2). 
Desert Sunshine Exposure Tests, Inc.

Box 135, Black Canyon Stage

Phoenix, Arizona 85020

\section{D A Y S T A G NA T I O N}

Company: CALMAC MANUFACTURING CORPORATION

OSET No: 18471S

Collector: Sunmat

Pressure Rating: 25 psi
Rack \#: 160

Angle: $45^{\circ}$ South

Start Dare: January 18, 1978' 3:50 p.m.

\begin{tabular}{|c|c|c|c|c|c|c|c|}
\hline zays & Date & $\mathrm{BTU} / \mathrm{Ft}^{2}$ & $\begin{array}{c}\text { Cummulated } \\
\mathrm{BTU} / \mathrm{Ft}^{2}\end{array}$ & $\begin{array}{c}\text { Ambient } \\
\text { High }\end{array}$ & $\begin{array}{c}\text { Tenperature } \\
\text { L Low } \\
\end{array}$ & $\begin{array}{l}\text { Wind } \\
\text { Velocity }\end{array}$ & Precipitation \\
\hline 1 & $1 / 19 / 78$ & 166 & 166 & 52 & 46 & 7 & 0.12 \\
\hline $2^{i}$ & $1 / 20 / 78$ & 273 & $439 !:$ & 50 & 40 & Calm & 0.9 .3 \\
\hline 3 & $1 / 21 / 78$ & 2155 & 2,594 & 58 & 38 & 5 & \\
\hline 4 & $1 / 22 / 78$ & 2063 & 4.657 & 61 & 40 & 8 & \\
\hline 5 & $1 / 23 / 78$ & 1834 & 6,491 & 57 & 39 & 1.3 & $\checkmark$ \\
\hline 6 & $1 / 24 / 78$ & 2033 & 8,524 & 57 & 35 & 10 & \\
\hline 7 & $1 / 25 / 78$ & 2125 & 10,649 & 56 & 33 & 7 & \\
\hline 8 & $1 / 26 / 78$ & 2232 & 12,881 & 61 & 35 & 6 & \\
\hline$\underline{9}$ & $1 / 27 / 78$ & 1557 & 14,438 & 68 & 41 & 8 & \\
\hline 10 & $1 / 28 / 78$ & 1841 & 16,279 & 76 & 50 & 10 & \\
\hline 11 & $1 / 29 / 78$ & 1974 & 18,253 & 74 & 50 & 7 & $\therefore$ \\
\hline 12 & $1 / 30 / 78$ & 177 & 18,430 & 56 & 48 & 16 & 0.42 \\
\hline 83 & $1 / 31 / 78$ & 269 & 18,699 & 53 & 47 & 4 & 0.14 \\
\hline 19 & $2 / 1 / 78$ & 1719 & 20,418 & 64 & 46 & 7 & $\cdot$ \\
\hline 15 & $2 / 2 / 78$ & 2184 & 22,602 & 71 & 47 & 9 & \\
\hline 86 & $2 / 3 / 78$ & 2277 & 24,879 & 71 & 48 & 12 & \\
\hline 17 & $2 / 4 / 78$ & 889 & 25,768 & 69 & 50 & 18 & \\
\hline 18 & $2 / 5 / 78$ & 616 & 26,384 & 71 & 51 & 6 & \\
\hline 19 & $2 / 6 / 78$ & 568 & 26,952 & 61 & 49 & Calm & 0.55 \\
\hline 20 & $2 / 7 / 78$ & 1738 & 28,690 & 64 & 44 & 5 & 0.12 \\
\hline 21 & $2 / 8 / 78$ & 1701 & 30,391 & 64 & $46^{\circ}$ & 8 & \\
\hline 22 & $2 / 9 / 78$ & 1731 & 32.122 & 68 & 49 & 8 & \\
\hline 23 & $2 / 10 / 78$ & 295 & 32,417 & 58 & 46 & 14 & 0.80 \\
\hline 29 & $2 / 11 / 78$ & 1077 & 33,494 & 52 & 41 & 12 & 0.54 \\
\hline 25 & $2 / 22 / 78$ & 1255 & 34,749 & 54 & 40 & 5 & \\
\hline 26 & $2713 / 78$ & 299. & $35,048^{i}$ & 51 & 39 & 3 & 1.07 \\
\hline 27 & $2 / 24 / 78$ & 491 & 35,539 & 50 & 36 & 5 & 0.08 \\
\hline
\end{tabular}

These do not meet $1500 \mathrm{BTU} / \mathrm{Ft}^{2}$, minimum requixements 
Desert Sunshine Exposure Tests, Inc.

Box 185, Black Canyon Stage

Phoenix, Arizona 85020

$\begin{array}{llllllllllllll}3 & 0 & \text { D A Y } & \text { S T A G N A T I } & 0 & N\end{array}$

Company: CALMAC MANUFACTURING CORPORATION (p. 2) r Rack :

DSET No:

Arigle:

Collector:

Start Date:

Pressure Rating:

\begin{tabular}{|c|c|c|c|c|c|c|c|}
\hline Days & Date & $\mathrm{BTU} / \mathrm{Ft}^{2}$ & $\begin{array}{c}\text { Cummulated } \\
\text { BTU/Ft }\end{array}$ & $\begin{array}{c}\text { Ambient } \\
\text { High }\end{array}$ & $\begin{array}{c}\text { Temperature } \\
1 \quad \text { Low }\end{array}$ & $\begin{array}{c}\text { Wind } \\
\text { Velocity }\end{array}$ & Precipitation \\
\hline 28 & $2 / 15 / 78$ & 1343 & 36,882 & 54 & 40 & 6 & . \\
\hline 29 & $2 / 16 / 78$ & 2395 & $39,277^{\circ}:$ & 57 & 36 & 8 & \\
\hline 30 & $2 / 17 / 78$ & 2244 & 41,521 & 59 & 36 & 6 & \\
\hline 31 & $2 / 18 / 78$ & 2428 & 43,949 & 62. & 39 & 18 & \\
\hline 32 & $2 / 19 / 78$ & 2413 & 46,362 & 62 & 40 & 15 & \\
\hline 33 & $2 / 20 / 78$ & 2365 & 48,727 & 61 & 38 & 9 & \\
\hline 34 & $2 / 21 / 78$ & 2402 & 51,129 & 74 & 42 & 12 & 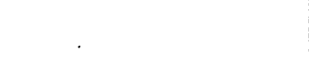 \\
\hline 35 & $2 / 22 / 78$ & 2421 & 53,550 & 73 & 47 & 7 & \\
\hline 36 & $2 / 23 / 78$ & 2406 & 55,956 & 73 & 49 & 11 & \\
\hline 37 & $2 / 24 / 78$ & 2317 & 58,273 & 70 & 43 & 12 & . \\
\hline 38 & $2 / 25 / 78$ & 2125 & 60,398 & 68 & 43 & 9 & \\
\hline 39 & $2 / 26 / 78$ & 1029 & 61,527 & 67 & 47 & 7 & 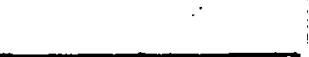 \\
\hline 40 & $2 / 27 / 78$ & 480 & 62,007 & 56 & 49 & 5 & 0.98 \\
\hline 41 & $2 / 28 / 78$ & 786 & 62,793 & 59 & 51 & 7 & 0.79 \\
\hline 42 & $3 / 1 / 78$ & 801 & 63,594 & 63 & 51. & 14 & 1.00 \\
\hline 43 & $3 / 2 / 78$ & 542 & 64,136 & 56 & 51 & 12 & 1.35 \\
\hline 44 & $3 / 3 / 78$ & $2410^{\circ}$ & 66,546 & 64 & 48 & 14 & \\
\hline 45 & $3 / 4 / 78$ & 686 & 67,232 & 65 & 47 & 10 & \\
\hline 46 & $3 / 5 / 78$ & 207 & 67,439 & 55 & 46 & 10 & 0.27 \\
\hline 47 & $3 / 6 / 78$ & 1845 & 69,284 & 62 & 46 & 15 & 0.07 \\
\hline 48 & $3 / 7 / 78$ & 2395 & 71,679 & 69 & 43 & 10 & \\
\hline 49 & $3 / 8 / 78$ & 2771 & 74,450 & 71 & 48 & 8 & \\
\hline 50 & $3 / 9 / 78$ & 2162 & 76,612 . & 73 & 48 & 9 & \\
\hline & $\begin{array}{l}: \\
\vdots \\
\vdots\end{array}$ & . & : & $\therefore$ & & & \\
\hline
\end{tabular}

These do not meet $1500 \mathrm{BTU} / \mathrm{Ft}^{2}$, minimum requirements 
TABLE 2.

4-HOUR STAGNATION PERIOD*

Company: CALMAC MANUFACTURING

DSET No.: 184715
Collector: SUNMAT:-

Date: MARCH 17, 1978

\begin{tabular}{ccc} 
Solar Time & $\begin{array}{c}\mathrm{T}_{\mathrm{a}} \\
\left({ }^{\circ} \mathrm{F}\right)\end{array}$ & $\underline{\mathrm{BTU} / \mathrm{ft}^{2} / \mathrm{h}}$ \\
\hline 1000 & 72.5 & 349.50 \\
1030 & 74.1 & 355.03 \\
1100 & 76.9 & 347.28 \\
1130 & 78.1 & 347.28 \\
1200 & 81.0 & 349.50 \\
1230 & 82.9 & 356.13 \\
1300 & 82.8 & 356.13 \\
1330 & 81.1 & 356.13 \\
1400 & 82.2 & 352.81
\end{tabular}

*Test was conducted with the collector mounted on an EEK (follow-the-sun) mount. 


\section{c. FINAL ASHRAE 93-77}

The data (Table $3 a, b, c)$, and the efficiency graph (Figure 1) are attached at the end of this section. Also attached is a graph (Figure 2) which compares the initial and final instantaneous efficiency results (reference is again made to the fact that the initial data were furnished previously).

Analysis of the efficiency data resulted in the following second order equation:

$$
n=0.633-1.014\left[\frac{T_{i}-T_{a}}{q_{i}}\right]-0.165\left[\frac{T_{i}-T_{a}}{q_{i}}\right]^{2}
$$

The $F_{R}$ at product for this test is equal to $0.633(63.38)$.

The overall heat loss equation is presented below along with its evaluation at three parameters.

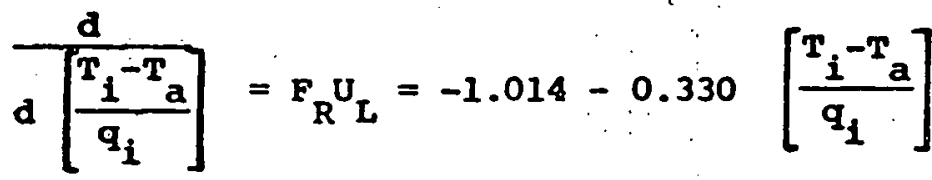

$$
\begin{aligned}
& \text { Inlet Parameter:* } 0.00 \quad 0.15 \quad 0.30 \\
& { }^{F_{R} U_{L}: * *} \quad-1.014 \quad-1.064 \quad-1.113
\end{aligned}
$$

${ }^{\circ} \mathrm{F} / \mathrm{BTU} / \mathrm{ft} \mathrm{t}^{2} \mathrm{hr}$

$\star \star \mathrm{BTU} / \mathrm{ft} \mathrm{t}^{2} \cdot \mathrm{hr} /{ }^{\circ} \mathrm{F}$, negative sign denotes loss 


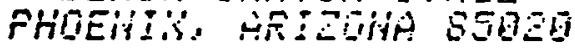

SOLAR COLLECTOR TEST DATH

COATAIYY: CAILATC

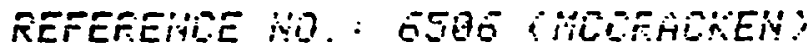

DSET TYiT. : 1 S4TIS

REFORT IUD: : FOBIIIAH

TEST DHTE: OTOAOPB
COLEETTER: SLIUHAT:

COWER: PIHETIO, GIVIEL

AFERTUER AFEA: QS. QO SD.FT.

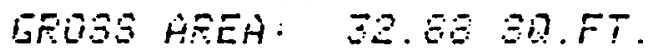

TRAIVEFER FLUID: WHERE.

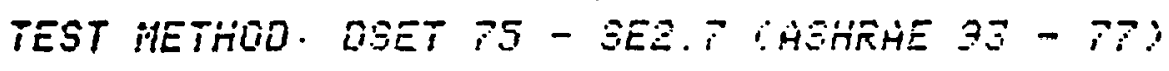

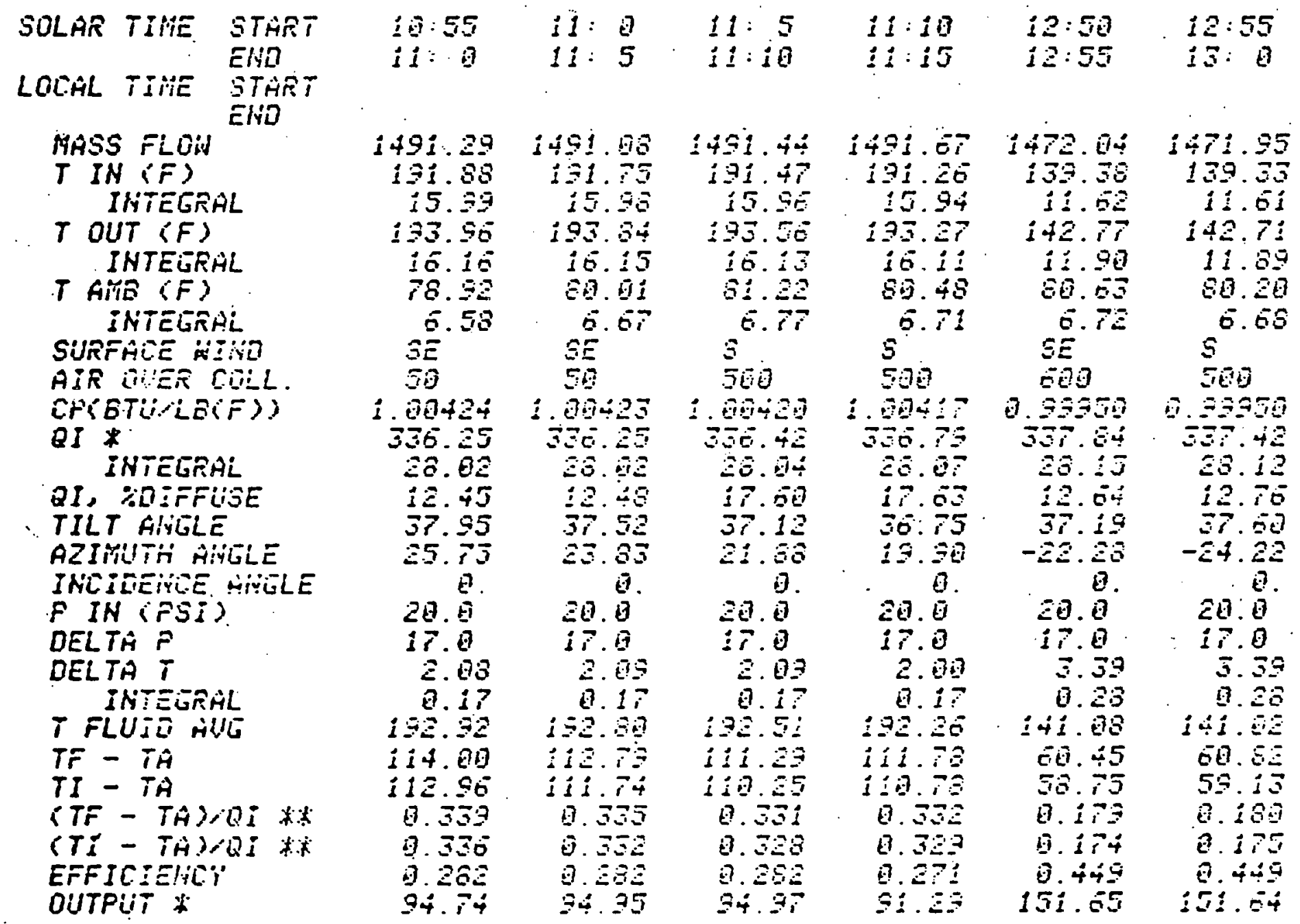


LABLE DS.

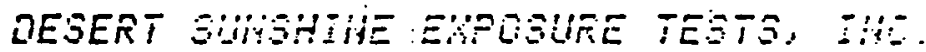
6006 is:

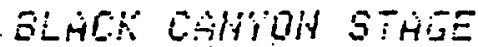

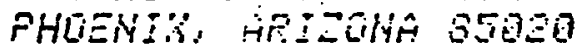

SOLAR COLLETTOR TEST DHTA

CoTPFiY'S: CHiLAMi:

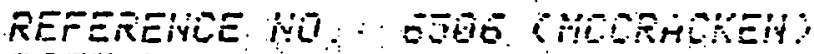

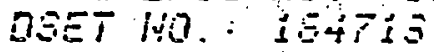

REFORT HUT. : POSIIAH

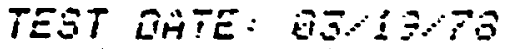

COLLELTOR: SUMHUTT

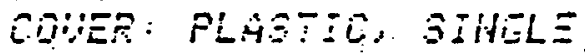

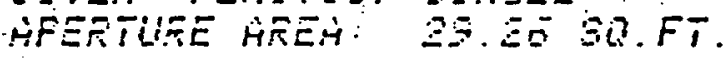

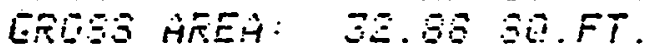

TRिHAFEF FL:TD: WHTER

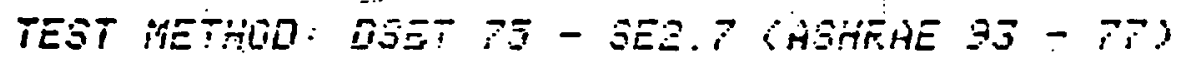

SOLAR TIHE START
LOCAL TIHE EIHD
BTART

HASS FLOW

T IH (F)

SUTEGRAL

$T$ OUTT $(F)$ IUTEGRAL

$T$ ATIS (F) INTEERALL

SUTFFATE HITLO

AiR UUER CGLL.

APCOTLLERT:

ini *

INTEGRAL

QT, 泟FFUEE

TIIT MiYGLE

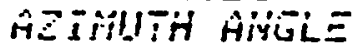

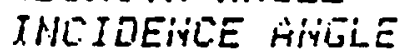

PIH (PSI)

MEITAP

TIELTAT $T$

THTEERATL

$T$ FIiTD AUE

$T F-T A$

$T I-T A$

(TF - THMQI W

(TI - TA) GI

EFFIEIETYCY

OUTFUT *

13: 1 is: 5

$43: 5$ i3:19

14: 45

34.50

if : 50

$14: 55$

i4:55

is:

i5: 8

i5: 5

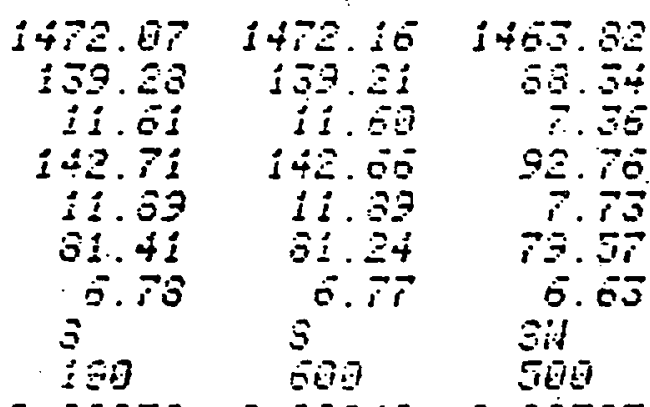

ه. 5530

337.63

2.

i.. 33

53.95

$-5.33$

$2 \stackrel{3}{\circ}$

i. 3

5.45

0.3

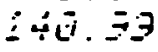

53.50

$\therefore i$

i.

a. is

i.

153.53

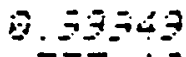

35.2

28.0

12. 70

30. 35

$-2.5$

i.

20.

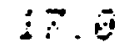

3.45

i. $\equiv$

140.5

53.0

5.97

बi.

จ. 17

Q. 459

1 34.5 a. 3975

320.

27.10

i4. 95

52.7

- $5 \overline{1}$

$2 \frac{6}{5}$

3.3

4.

$\overline{3} \overrightarrow{3}$

$5 \%$

4.93

a. $\overrightarrow{0}$

0. 1.04

a.

i. 5

ise. 4
1463.81

80.38

$\overrightarrow{3} \overrightarrow{3}$

Fe.

7.73

Qivi.i4

6.68

5

807

Ei. $9 \div 7 \div$

ज小ञ

$25.5 \overline{5}$

15. 13

53.0

$-50.35$

20.5 .

1. 0

บั. 48

i]. 37

$=0.50$

30. 44

ㄱ.

i.

C. $7=5$

3. 04

i. $=50$
1463.77

60.42

7. 37

S. $\mathrm{Ai}$

$\vec{i} \overrightarrow{3}$

60.05

0.67

3

600

a. 35958

315.75

20.0

15. 3

54.51

$-53.5$

i.

20.5

30.

4.57

$\overrightarrow{3 i}$

$=0.5$

i. 0.5

B. 37

i7. $0 \div 3$

6.

Q7. $=3$

i $=5$
1463.75

60.49

7.37

92.53

$\vec{i} \cdot \overrightarrow{i t}$

79.78

6. 54 s

400

$0.59750^{\circ}$

$\$ 20.30$

20.08

15.

55.4

$-00.45$

20.5

i3.

4. $\bar{\therefore}$ !

B.

$=0$.

10.5

농

E.

o. 3

i. 6

$\therefore=80$ 
TABLE 3c.

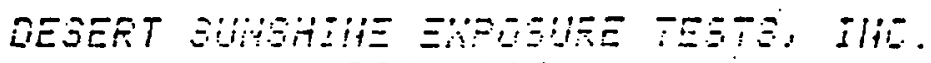
60i 100

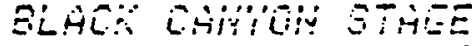

priogin,

SOLAR COLLECTER TEOT GHTH

J COMPAIYT BALHAC

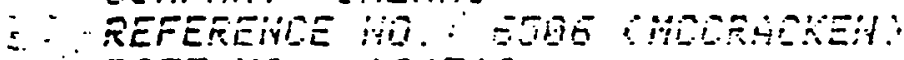

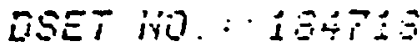

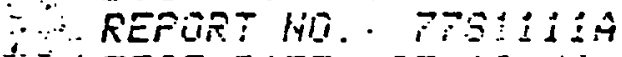

TEST LUTE: BSAOHO

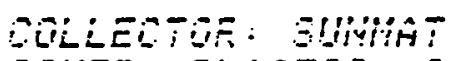

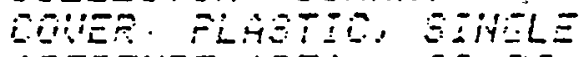

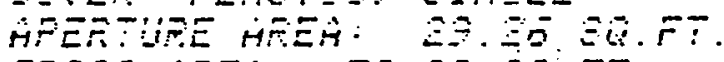

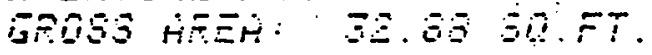

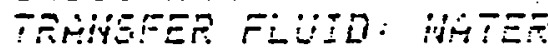

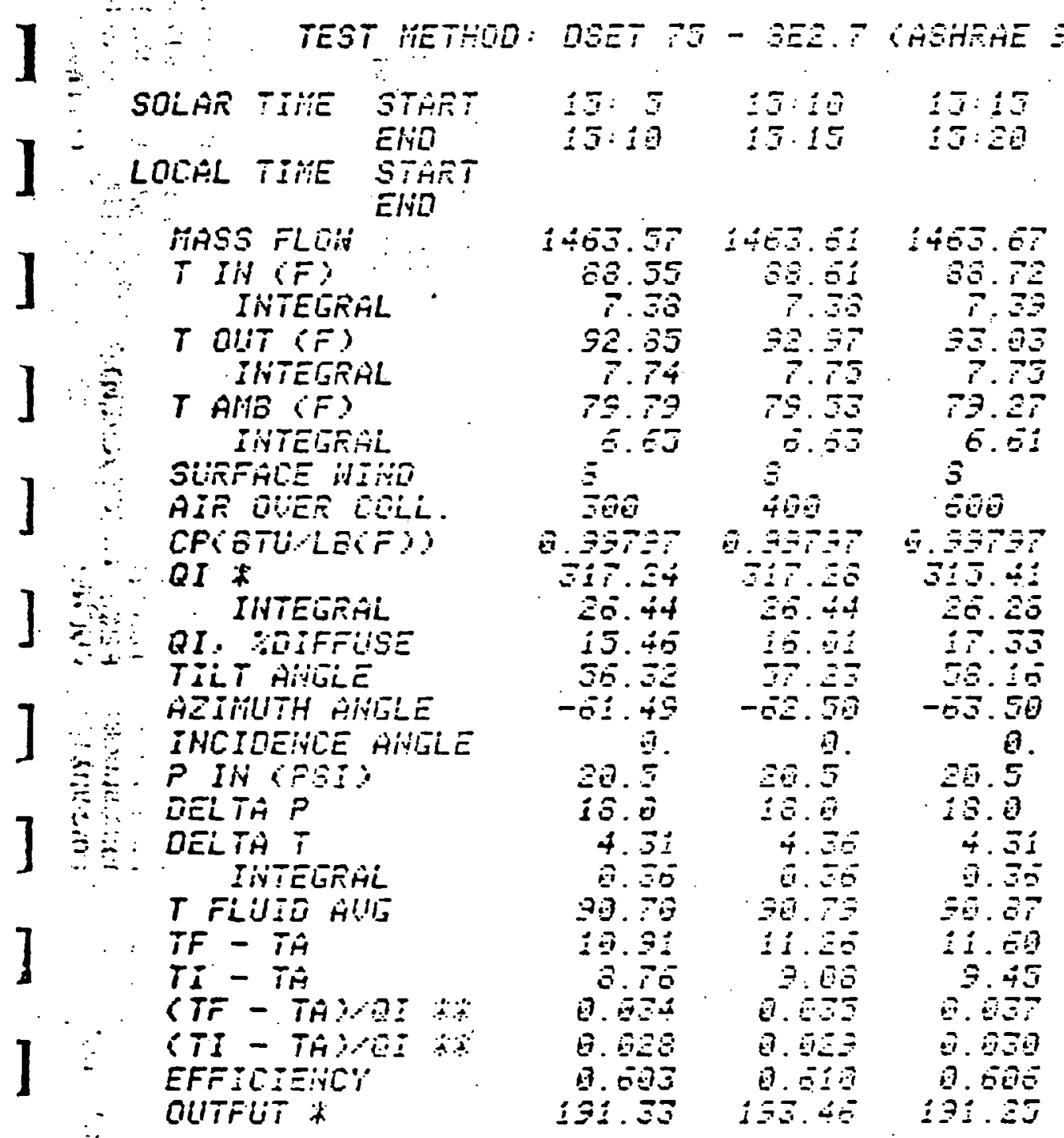


DESEAT SUASHINE EROSURE TESTS, INC. Box 185 Black Canyon Stage

Phoenix, Arizona 85020
CORDATY:

REFERENCE! G5OS (MCCRACKEN) DSET NO.:

REPORT NO.8

DATE:
TEST METHOD, DSET 75-SE2. 7 (ASHRAE 93-77)

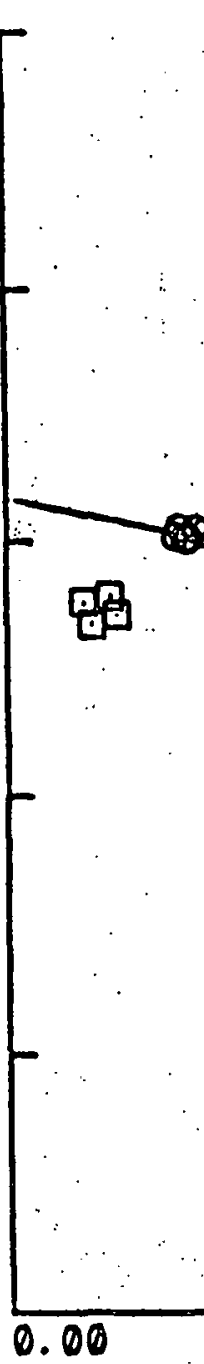

.

COLIECTOR: - SUNMAT

COVER: PLASTIC SINGLE AVG FLOW RATE: $N / A$. AVG AMBIENT TEMP: $N / A$. AVG INSOLATION: $N / A$. COLLECTOR AREA: N / A.
1.00

0.60

N

0.40

0.20

0.00

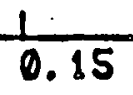

$\frac{1}{0.20}$

- Field Data

( Special Test Data

- Analysis

PARAMETER (TI-TA) / QI

Figure 1. 

D. SPECIAL TEST

The four instantaneous efficiency values obtained at an inlet fluid parameter of approximately 0.015 is presented in Table 4 and on Figure 1 (these data are designated by squares). 


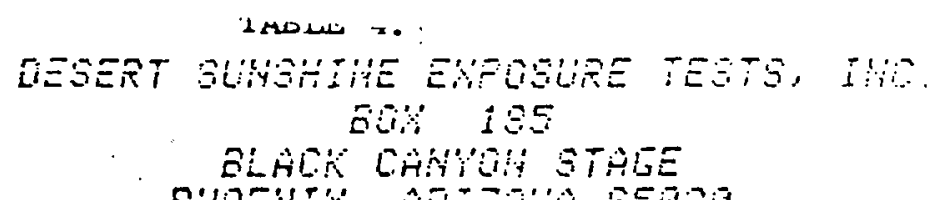

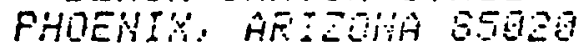

GULAR̂ COULELTLR TEST GHAH

COUAPAMU: CALHAC

REFEREHEE [YI]. : ESBE HOLRACKEN?

DSET NO. : $184 T \mathrm{~B}$

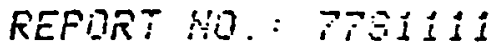

TEST GATE : QOZZZTS

COLLECTTR: SHHHAT

COUER: HOHE

AFERTURE AREA: 29.25 SR.FT. GRDSE AREA: 32.08 SOFT.

TRAHIOFER FLLITD: WHTEF

\section{TEST HETHOD: DEET PJ - SEZ.P (AGHREE 93 - TT)}

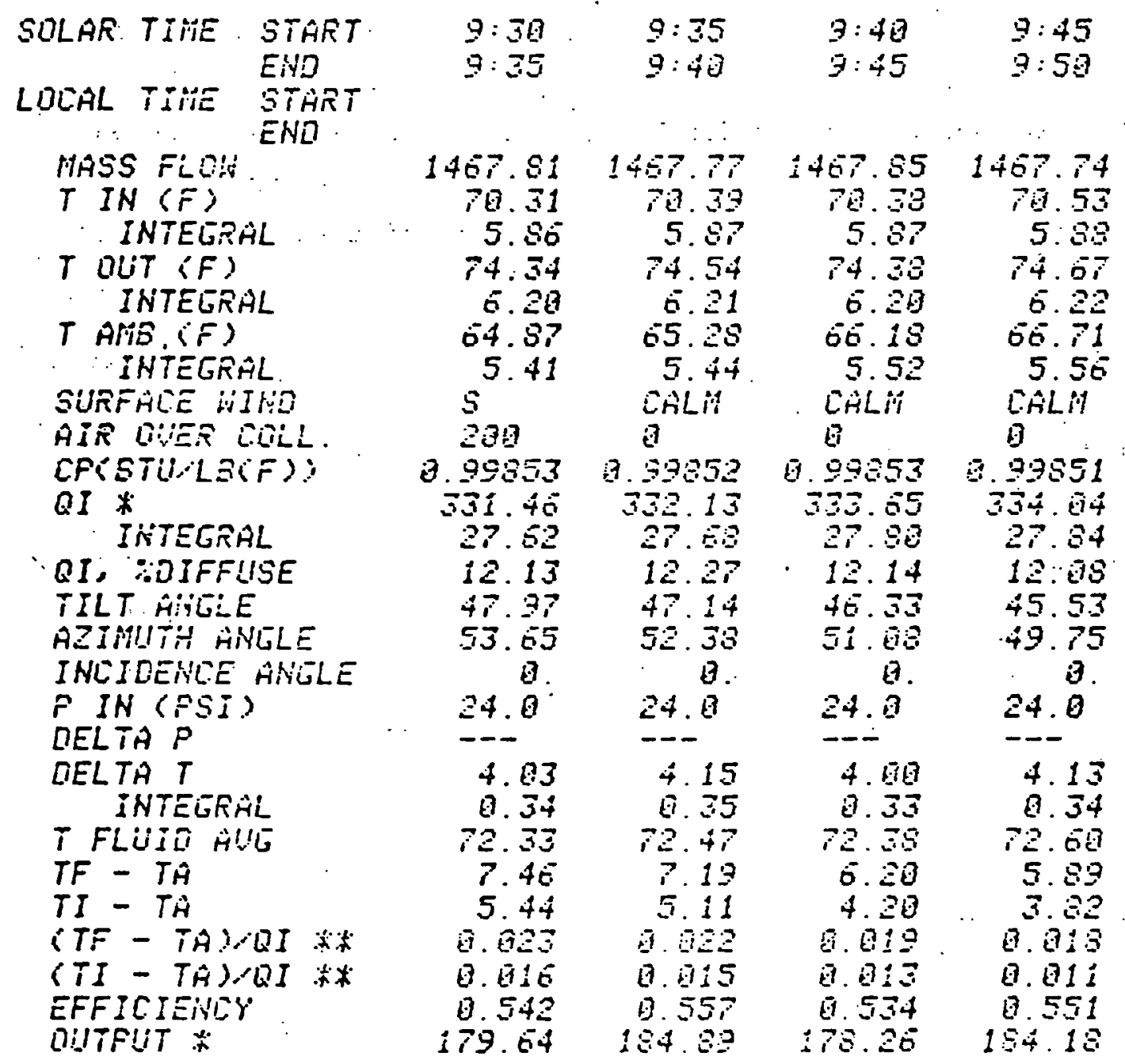


30-Day Stagnation and ASHRAE 93-77 Retest

The visual changes that occurred in the collector during stagnation were substantial. Moisture entered the collector during stagnation. Severe outgassing occurred and accumulated predominantly on the inner surface of the transparent cover. As shown in Figure 2, the thermal performance was not seriousiy affected as a result of these observed changes. This is attributed to the general nature of the collector -- since plastic/plastic thermal bond result in lower $F_{R}$ values than would be experienced by metal/metal (thermally) bonded plates. Thus, this type of collector is judged to be less sensitive to these types of changes than might be expected. No predictions of durability can be made for stagnation periods of greater than that employed in this test.

Special Test

The lower efficiency values obtained when the glazing was removed (Table 4) - - compared to the efficiency of the glazed (covered) collector, is expected for collectors having characteristically low $F_{R}$ values (heat removal efficiency factor). The greater energy incident on the plate resulting from removal of the glazing was overshadowed by increased thermal losses lotherwise contained by the glazing) due to higher plate temperatures that result ficon a low $F_{R}$ value.

\section{CONCLUSION}

The Sunmat liquid collector was tested in accordance with ASHRAE 93-77 and the subsequent 30-day stagnation and ASHRAE Standard 93-77 retest were performed in conjunction with both the HUD requirements for the Hot water Initiative and applicable sections of the January 1, 1975 Interim Performance Criteria. ASHRAE 93-77 is the generally accepted, industry-wise standäd for testing the thermal performance of solar collectors. 
Desert Sunshine Exposure Tests, Inc. Box 185, Black Canyon Stage

Phoenix, Arizona 85020

Attention: Mr. Bill Putman
1. E. Warno. If.PE

1. C. Bentrits. Pt.

iN. L Mirrs, PE

o. I Hams. P.E.

C. K. Copplandi. $\mathrm{P}$

F. G. Lursm.Pr

E Mankuluh P'
I I Dinumkki,p F:

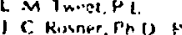

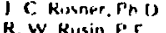
R. W Rusin, F' $\mathrm{E}$ $M K$ Hathm, $P$ : $K$ L Recher.if

E H Lewis. r.

C. Hothinsein Pi

Re: Evaluation of Field-Assembled

Sunmat Liquid Flat Plate collector

In accordance with your request, we have evaluated the submitted Sunmat liquid flat plate collector. This evaluation was completed. at E.T.L., Inc. by the undersigned on 2-21-78.

* The collector plate was disassembled and the individual components of the apparatus were examined and compared with the Interim Performance criteria, the construction drawings and Installation, operation and Service Manual. The enclosed list enumerates each of the construction drawings and the discrepancy found.

${ }^{*}$ Conclusion: There was no divergence from the Irterim Performance Criteria, the construction drawings, or service manual that would appreciably effect the installation, operation, ox efficiency of the device.

If any questions should arise concerning this evaluation, please contact us at your convenience.

Respectfully submi.ted,

ENGINEERS TESTING LABORATORIES, INC.

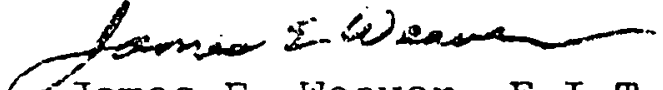

James E. Weaver, E.I.T. bd 
Desert Sunshine Exposure Tests, Inc. Evaluation of Field-Assembled Sunmat Liquid Flat Plate Collector Invoice/Lab No. 221-0051

Page-2

The following list enumerates each of the construction arawings and the deviation found. Some of the variations listed below are required by service manual for the field-assembled model and are noted as such.

Drawing No. A-S126

A-SI09-A

A-S 115

$A-\operatorname{Sl} 14$

A-S106

$A-5119$

A-130P-B

A-SIII

$A-\operatorname{Sil} 7$

$A-\sin 3-A$

$A-\operatorname{S1} 18$

A-S 108

B-ST277-D

\section{Discrepancy}

The collector panel was mounted on a 4' $x$ 8' X 1" thick plywood base for stability: The glazing panel was glued around it's perimeter, and the top and bottom trim strips were eliminated as shown in the service manual for field assembled collectors.

Constructed as shown.

Constructed as shown.

Constructed as shown.

This item not included on field assembled collectors.

Constructed as shown.

Constructed as shown.

Constructed as shown.

Constructed as shown.

Constructed as shown.

Constructed as shown.

The drawing indicates an 8", $\frac{1}{4} "$ dia. copper tube with 1/8" dia. holes in the condenser dryer. The bill of materials specifies a 6" copper tube and the dryer sample had a 2" copper tube.

Both header pipes were 45" in length with 30 take offs spaced over $391 / 16^{\prime \prime}$. The drawing indicates the header pipes to be 44 " in length with 30 take offs on $15 / 16^{\prime \prime}$ centers for $381 / 16^{\prime \prime}$. 
Desert Sunshine Exposure Tests, Inc. Evaluation of Field-Assembled Sunmat Liquid Flat Plate collector Invoice/Lab No. 221-005l

Page-3

Drawing No.

$$
\begin{aligned}
& B-5127 \\
& C-156 P-C \\
& C-S 125-B
\end{aligned}
$$

Discrepancy

This item not included with submitted panel.

Constructed as shown.

constructed as shown except as previously noted. 


\section{SECTION 2}

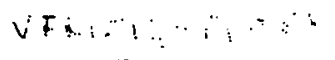

VERIFICATION REPORT

TO

NATIONAL AERONAUTICS AND SPACE ADMINISTRATION

MARSHALL SPACE FLIGHT CENTER

FOR

THE SUNMAT LIQUID FLAT PLATE COLLECTOR

CALMAC Mfg. Corp. 150 S. Van Brunt st. Englewood, NJ 07631 


\section{VERIFICATION SUMMAR Y}

The report includes an item-by-item breakdown of the applicable IPC, together with the appropriate verification based on analy sis, similarity, inspection or testing. The IPC, prepared in 1975 by the National Bureau of Standards, is generally considered to be among the first set of nationally recognized standards and codes for solar heating and cooling.

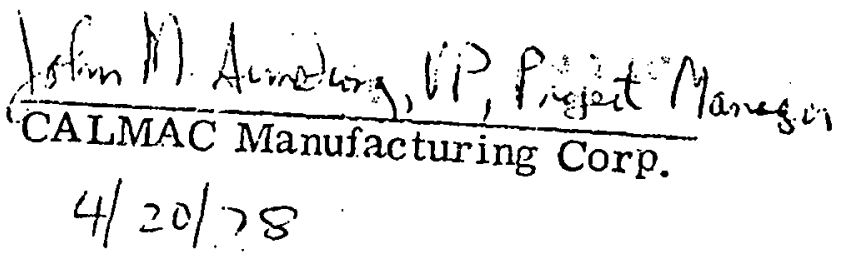


1.2.4 Crtterton Operactonal Impairment. The functional capability of the oHh ayotem/
ouboyocen ahali not be impasred to a greater extent. than conventional oyotems when syotem repalrs or modiflcations are belng made.

Fvaluation Englnecring review of spectefcations and drawings.

Conmentary Thio criterson is intended to ensure that the shutdown for repals or modsflcation of solar powered portions (e.g. the collector gubsystem) of the DHW system/subsystem w111 not Impalt the function of the DHW syotem/suboyocem for perlods of time longer than those expected for conventionol hot water equipment.

The duplication of components such as heat exchangers, controls and pumps 18 dependent upon the degree of integration of the auxtlisty energy subayatem and the avallability of replacement parta.

1. The collector is designed for use in systems having conventional systems for backup. In the event of shutdown for repair the backup system will bale over. Nothing in the SUMMAT subsytem influences the operation of the
backup system.

2. Several features of the SUNAT design facilitate repair and minimize down time. The zipper lock on the plastic frame alloys easy access to the absorber for repaii. Leaks in the tubing can be repaired on site with the use of splicer tribes.

1.3 Requirement Collector performance. The solar collector shali absorb and convert Incidene oolar energy into useful thermal energy. The collector ahall be capable of diosiparing thermal energy, where this function is included in the design.

1.3.1 Criterion collector efflclency. The collector subsystem (Including reflectors Where applicable) shall be capable of absorbing and converting Intident solar energy into useful thermal energy at lis designed eqficicncy under operating conditions. For applications enploylng nocturnal radiacion, the collector ghall dissipace thermal energy at the design rate under design operating condictons.

Evaluation Engtricering evaluation of drawlings, analytical calculations and/or test data.

An onialytical model, when used, shall include radiant, convectue and conductive heat transfer, where appropriace.

The deatgn collector thermal efficlency may be experimentally vertSled uedlizing a full-scale test panel or a model. test panel of suffictent size to have equivalent full-scale thermal characteristics.

It so intended that testing be performed only if performance data for the particular collector or one with similar materials and/or conflguration 18 not avallable. Becaube of the Inffluerce of solar rad1ae1on characteriat1es, climatic condtions and ayorem operating requdrements on performance, experimental evaluastong shall friclude hoat cransfer medla flow rates and temperatures constocent with the geographic region and system conditions.

Commentary Some examples of analytical methods and data presentation are shoun In the references [1] [12] [13] [14] [15] [16] [24] [25] [26] [27] [36] [37]. Descriptions of collector test techniques and representative test data are presented in references [13] [28] [29] [30] [31] to 1llustrate methodologies considered to be state-of-the-ort. The use of matertal, fluid and insolation property data avaslable in the open 11terature 18 encouraged.

See results of collector efficiency testing. 
Thermal storage performance. When included in the design, the storage subsystem shall be capable of providing 1ts rated output under design loads.

Storage capac1ty and rate. The storage subsystem shall provide sufficient heat transfer rates and thermal energy capacity to absorb and store energy at the maximum design collection rate and, when fully charged, supply energy for its design time perfod with no solar energy or auxillary energy input.

Engineering review of drawings, calculations and/or test data.

A thermal analysis of the storage subsystem shall be performed to determine the thermal energy storage capacity, heat losses, energy. addition rate and energy extraction rate under operating conditions. For deslgns where adequate calculations are not possible these parameters shall be experimentally determined utilizing a full-scale tes: specimen or a model test speclmen of sufficlent size to have equivalent full-scale thermal characteristics.

\begin{abstract}
Descriptions of storage techniques and representative test data are presented in references [12][13][14][16][32][33][34]. to 111ustrate methodologies considered to be state-of-the-art. The thermal capacity is a function of system dynamic characteristics and may be sized to Include factors such as insolation level, collector area, thermal loads, energy loss, temperature gradients, material thermophysical properties and auxillary energy type and amount.
\end{abstract}

The collector is designed for use in systems both with and without storage systems. Collector efficiency data should be used to determine. the optimum size of the thermal storage sys.tem.

2.1 Requirement System design conditlons. The systems for heating '( $\dot{H})^{\prime}$ and combined heating and cooling $(\mathrm{HC})$ and the domestic hot water (DHW) system/ subsystem shall be capable of functioning at their designed flow rates, pressures and temperatures.

2.1.1 Criterion

Equipment capabilities. Pumps, fans, or other components shall bë slzed to move the heat transfer fluid through the collector, piping and/or ducts at design flow rates: !.

Evaluation Review of drawlings, specifications, historical performance, previous test data, and design calculations. Systems or applications that do not lend themselves to engineering analysis may require prototype tests to demonstrate compliance.

Commentary In order to transfer heat through the system/subsystem, a number of different transfer approaches such as gravity circulation, combined forced and gravity circulation, or forced circulation may be used. 1. The maximum operating temperature and pressure of the collector is $210^{\circ} \mathrm{F}$.
and $20 \mathrm{PSI}$. Maximum al lowable tube temperature is $350^{\circ} \mathrm{F}$ and the burst pressure and 20 PSI. Maximum allowable tube temperature safety margins are allowed between design and maximum allowable.

2. The pressure drop through a 50 -foot mat at $110^{\circ} \mathrm{F}$ is $9 \mathrm{PSI}$, which is well below the maximum design operating pressure of 20 PSI.

3. The minimum flow rate required to force fluid through the furthermost tubes of the mat is 2 GPM. 


\subsubsection{Criterion}

Noise or erosion-corrosion. The piping or ducts and associated fittings shail be sized to carry the heat transfer fluid at design flow rates without excessive nolse, as defined by HUD[1], or erosion-corrosion.

Evaluation Reviev of drawings, spectflcations, historical performance, prevtous test data and design calculations.

Commentary In order to prevent whistling noise in piping and cavitation noise In fittings and valves, 1t is recognized practice to linit veiocities of transfer fluids to $8 \mathrm{fps}[2]$. Lower velocities may he requifed deperding on the linit set by the pipe manufacturer to prevent deteriorarion of their piping materials due to erosion-corrosion. If is comson practice to limft. flow velocitles in small diameter copper tubtng to 4 fps when water having a pH value lower than 6.9 or softened vater is used. A velocity of $4 \mathrm{fps} 1 \mathrm{~s}$ comonly used as the upper limit for hot vater plping with working temperatures above $150^{\circ} \mathrm{F}$ for copper tubing[2]. Sora equipment designs may require higher flow velocities fn order to Inhtbit scale formation. In alr ducts, the velocities normaliy should not exceed recognized values, e.g.; the values listed on U.I. labels.

The velocity of fluid through the header is the limiting factor for this criterion as the cross-section area of the header is smaller than the total cross-section area of the 30 SUNMAT tubes (Header: $(3 / 8)^{2} \times 3.14=$ $.442 \mathrm{in}^{2}$; tubing: $\left.(3 / 32)^{2} \times 3.14 \times 30=.828 \mathrm{jn}^{2}\right)$. The velocity of $4 \mathrm{fps}$ sets a flowrate maximum of about $5 \mathrm{gpm}:(3 / 8)^{2} \times 3.14 \times 4 \mathrm{fps} \times 12^{\prime \prime} / \mathrm{ft}=$. 21.2 in $3 / \mathrm{sec}=.0123 \mathrm{ft} 3 / \mathrm{sec}=.77 \mathrm{pounds} / \mathrm{sec}=.0924 \mathrm{gal} / \mathrm{sec}=5.54 \mathrm{gpm}$. For a 50-foot mat this translates into a difference in temperature between the inlet and outlet of the collector of $19^{\circ} \mathrm{F}$. for fairly extreme conditions:

$$
\frac{200 \mathrm{ft}^{2} \times 300 \text { BTUH } \times 80 \% \text { eff }}{5 \mathrm{GPM} \times 60 \mathrm{~min} / \mathrm{hour} \times 8.33 \# / \mathrm{gal}}=19.2^{\circ}
$$

\subsubsection{Criterion}

Operating cond1tions:- Collectors, space heaters, water heaters, pumps, valves, regulating orifices, pressure regulators and similar components shall be capable of belng operated over the pressure and temperature ranges anticlpated in actual service without breakage, rupture, binding, galling, or significant loss in pressure that could impair their intended function:

Evaluation Review of drawings, speciflcations, historical performance, previous test data and design calculations. Systems or components that do not lend themselves to engineering analysis shall be tested at the maximum and mintmum service temperatures with anticipated fluid precoures. To show compliance with this criterion it is destrable that the design consist of components that are covered by recognized standards, where avallable, and are specified by the manufacturer to be sultable
for the pressure, temperature, and flow application. 


\section{Contract \#NAS8-32253}

Project: Collector

1. Item Being Tested: Ability of collector to operate over anticipated range of temperature and pressure.

$$
2.1 .3
$$

2. Test Objectives: To verify that collector can be operated over the pressure and termperature ranges anticipated in actual service without breakage, rupture, binding, galling, or significant loss in pressure that could impair its functioning.

3. Location of test facilities and scheduled test dates:

CAIMAC Factory, simulatneously with efficiency testing, Mowh 15 . Apuif 15

4. Prerequisites for Passing or Failing:

During and after opeption at different temperatures and pressures within the normal operating range, the collector shall not show any signs of system failure.

5. Test Procedures: This testwill be run simulatneously with the efficiency testing. The collector will be operated at a wide range of temperatures and pressures, up to $2000 \mathrm{~F}$ at $40 \mathrm{psi}$, and observed for any indication of failure of any part of the system.

6. Test Results: The collector was operatsed at nomal operating temperatures and pressures during the period of July and August. During this period the collector was allowed on accasion to stagnate, which brought the temperatures up to $2000 \mathrm{~F}$ and above (see test results of test of fail-safe system). No damage was observed at absorber temperatures of $200^{\circ} \mathrm{F}$. 
Flutd flow in collectors. When an array of collectors is connected by manifolds, provision shall be incorporated in the manifolds and/or collecturs to maintain the design flow rate of the heat cransfer fluid through each collector.

Evaluation

Review of drawings, specifications, historical performance, previous test data, and design calculations or testing to determine that each collector will receive its deslgn flow rate.

Commentary

Because of friction in the manifold, flow rates may be inadequate through collectors remote from the pump or other fluid supply source. This can result in inefficient collector operation: The provision of flow regulating valves is one means of correcting for this problem. Another method is the use of reversed supply and return headers foi parallel arrays of collectors with graduated header sizes as the flow rate in the header changes. Useful design infomation is given in
reference [5].

One collector can be connected to the supply/return plumbing system through the header manifold system of one other collector. This limitation is outlined in the collector manual.

This configuration is subject to the 5 GPM maximum flow rate ceiling set to avoid noise and erosion-corrosion problems. See Criterion 2.1.2. This means that using this configuration the maximum flow rate through each collector is $2.5 \mathrm{GPM}$.

2.1.5 Criterton Encrapped a1r. When liquid heat transfer fluids are used, the system shall provide suitable means for alr removal.

Evaluation Review of drawings and specifications.

Commentary Trapped alr in a piping system can impede the flow of liquids through plping, decrease pumping efficlency and otherwise reduce system efficlency. Possible laing up of exposed fittings is an important conalderation.

An air vent should be installed in the at the inlet header of the collector. Because of the small inside diameter of the tubing in the collector trapped air is readily swept away by circulation of fluid through the system. As a result it is possible to install the collector with the inlet and outlet headers located at the lower end of the installation.

The ease of having air swept out of the tubing has been proven in applications using the ICEMAT, which has a similar size and configuration to the SUMMAT. We have been able to sweep air out of ICEMATs 200 -feet long on . slopes used for refrigerated toboggan slides. 
2.1.6. Criterion Thermal expansion of fluids. Adequate provistong for the thermal expanision of heat crangfer fluids that would occur over the service temperature range shall be incorporated inco the systen designs.

Evaluation Review of drawings, spectflcations and design calculations.

Comentary Water expands about $4 \%$ in volume when heated from $40^{\circ} \mathrm{F}$ to $200^{\circ} \mathrm{F}$. Other heat transfer fluids may have difterent coefficlents of volume expansion. Means should be provided in the system design to contaln this additional fluid volume.without exceeding the operating pressure of the system or resulting in spillage.

An expansion tank is required in the collector loop. See manual.

\subsubsection{Criterion \\ Pressure drops. Pressure drops shall not exceed the limits specifled \\ Evaluation Review of calculations, and detalled plan and elevation drawing layouts. \\ Commentary Since the energy requirements of pumps and fans are a function of the system flow resistance, pressure drops should be kept as low as possible, commensurate with good design. The unnecessary use of fit- tings such as bends, tees, globe valves, reducers, or obstructions to flow should be avoided by careful arrangement of piping runs. Accepted practices for plumbing design are discussed in standard plumbing guides[6] [7].}

See graph showing pressure drop vs. collector length vs. fluid type and temperature. 
CHLMAC

Contract \#NAS8-32253

TEST RECORD

Project: Collector

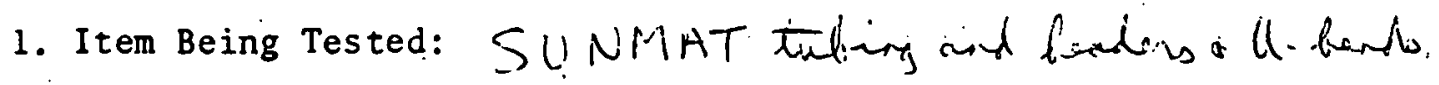
$2,1.7$

2. Test Objectives:

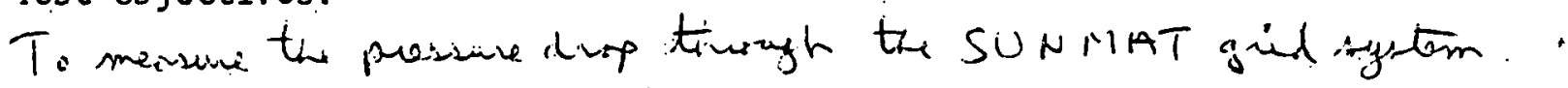

3. Location of test facilities and scheduled test dates:

CAL MAC fairy, Morin 1-30

4. Prerequisites for Passing or Failing:

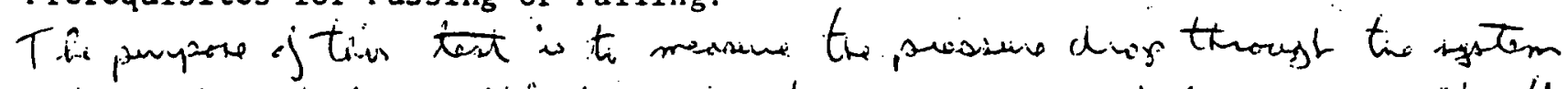

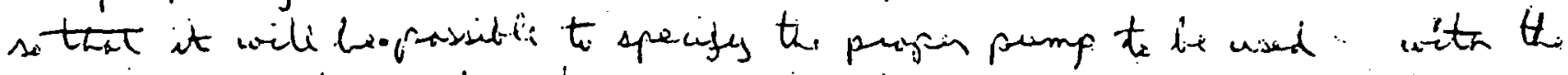

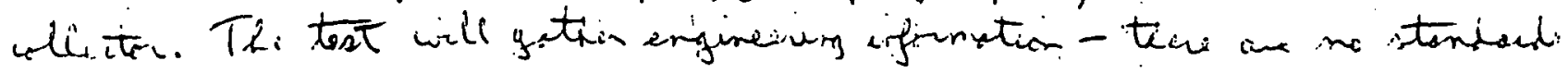
th lo met.

3. Test Procedures:

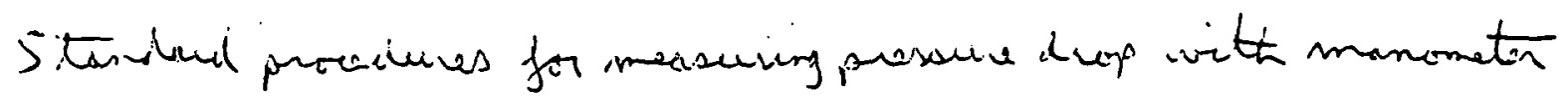

6. Test Results:

See attached Loss us. Flow Chat

36 


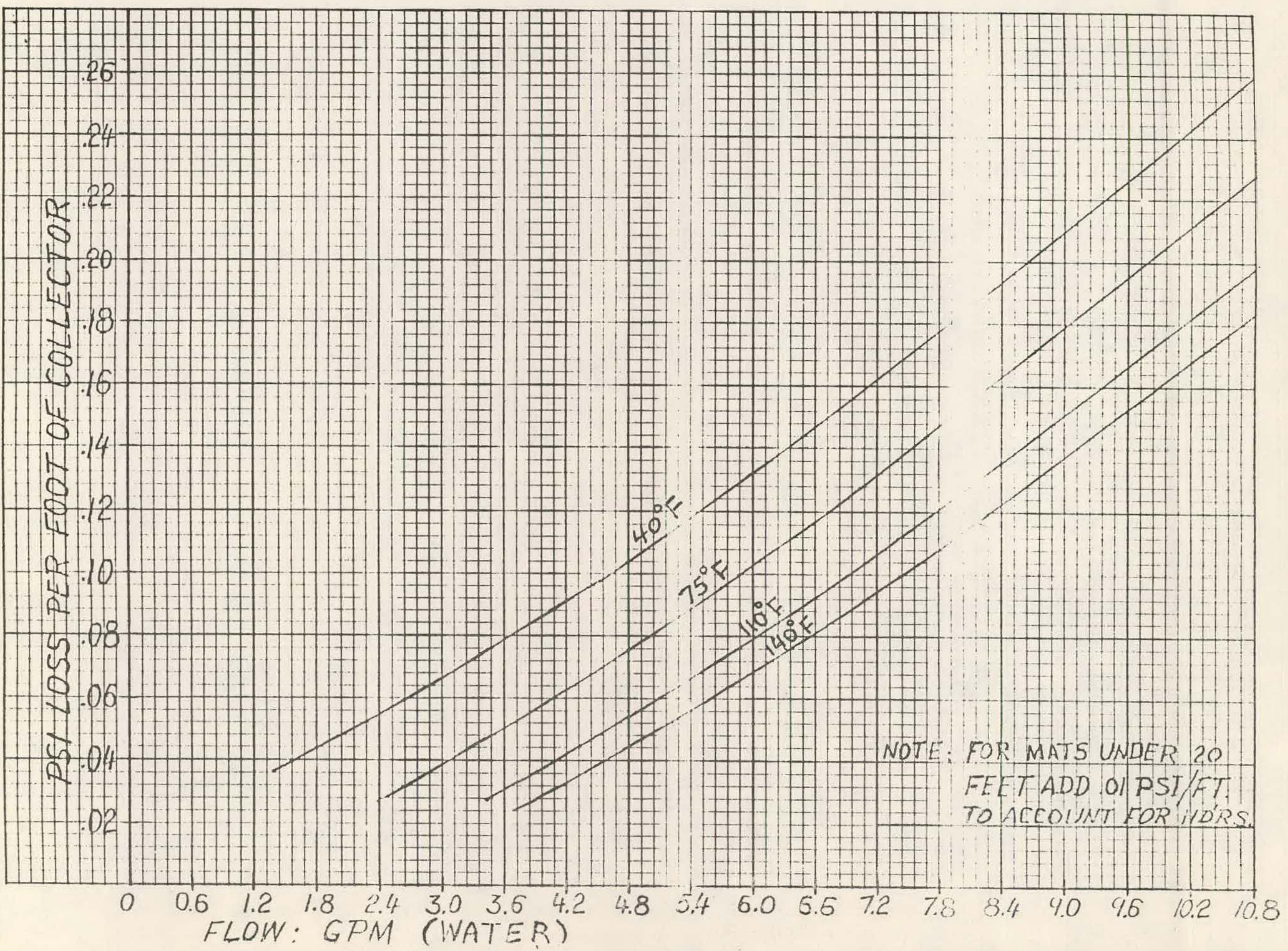



system shall not cause damage or malfunction of the system or Its components.

2.2.1 Criterion Vibration stress levels. Vibrations in piping, ducts, instrumentation I1nes, and control devices shall be controlled to reduce stress levels below those that could cause fatigue and subsequent component damage.

Evaluation Review of drawings, specifications, historical performance, and previous test data for adequate piping and equipment supports.

Commentary Examples of possible vibration sources in piping are as follows:

a. Lengths of piping and connecting equipment that are resonant with pressure pulsation frequency.

b. Vibration resulting from motors, pumps, fans, and compressors which are not properly mounted.

c. Water hammer and quick closing valves.

d. Expansion and contraction of piping on hangers.

e. Wind pulsations on certain lengths and diameters of piping supported by loose hangers or supports. Conventional safeguards in the design and instalition of the system must be
followed.

2.2.2 Criterion Vibration from moving parts. Pumps, fans and compressors or similar equipment shall be balanced and/or mounted in a manner that will avold vibration that could cause damage or excessive nolse as defined by HUD [1].

Evaluation Review of drawings and specifications. P'rototype inspection and testing if deemed necessary. The equipment supporting structure shall not have nacural frequencles within \pm 20 percent ut the operating speeds. The equipment wher mounted and placed in operation should not exceed a self-excited vitiration veloctty of 0.10 inches per'second when measured with a vibration meter on tie bearing caps of the machine in the vertical, horizontal, and axial Jirections or measured at the equipment mounting feet if the bearing caps are concealed[8].

The collector contains no moving parts and is not susceptible to the type of vibration described. 
Vacuum relief protection. Closed sturage ranks and plping located at elevations above the system served shall be suicably protected agalnst collapse by pressure if subjected to a vacuum. Such components shall be designed to withstand such pressures or have vacuum reliet protection.

Evaluation Review of Uruwings ind specifications.

Commentary Possible collapse of large diameter tanks and piping ty atmospher1c pressure is an imporcant design consideration[ll].

The SUMMAT EPDM tubing, the copper U-bends and the copper headers are all of small diameter and can easily withstand a vacuum. Collectors have been subjected to vacuums of 10 PSI with no visible change in the tubing or the copper components.

..............

2.2.5 Criterion Thermal changes. The system components and assemblles shall be designed to allow fur the thermal contraction and expunsion that would occur over the service temperature range.

Evaluation Review of drawings, specifications and calculations.

Conuentary Plping and other components may expertence changes in dimenstons as a result of temperature changes. Such changes can result in excessive stresses within the plping, piping supports, structure, pumps, compressors, and solar collectors if means are not incorporated in the plpling system design to allow for the thermal movement.

Stresses within the collector resulting from thermal expansion and contraction are accomodated by the high degree of flexibility of the materials used in the collector. The EPDM absorber tubing stretches and flexes adequately. to absorb stress in the absorber system. The polyshim glazing seal absorbs stress between the glazing and the frame. The use of elongated holes in the mounting frame allow's for differential expansion between the collector and the supporting structure.

\footnotetext{
2.2.6 Criterion Flexible fulltes. All systems employlug heat transfer fluids shall be designed to be capdble of accomotiating ilexing of plumbing and fictings.

Evaluation Review of drawings illu specifications.
}

Points where the inlet and outlet headers pass through the collector wall and join the supply and return plumbing are sealed with flexible materials to absorb flexing from expantion and contraction and from mechanical stress. Normal precautions in supporting the supply and retum liries must be followed. 


\subsection{Requirement}

2.3.1 Criterion

Cricerson

Evaluation

Commentary
Leakage prevention. System assemblies containing heat transfer fluids shall not leak to an extent greater than that specifled in the design when operated at the design conditions.

Pressure test: nonpotable fluids. Those portions of the $\mathrm{H}, \mathrm{HC}$ and $\mathrm{DHW}$ syotems which contain heat transfer fluids (other than afr) and are not: directly connected to the potable water supply shall not leak when pressures of not less than $1-1 / 2$ times the1r working pressure are imposed for a minimum of 15 minutes.

Review of speciflcations and cesting. The rese pressure shall be applied for a perlud of time necessary to inspect each joint for leakage. The pressure gage would be observed for this perlod to determine that a pressure drop has not occurred.

Varlous building codes differ with regard to pressure tests. One plumbing code requires hydrostatic testing at the working pressure for water supply plping[12]. Another code requires hydrostatic testing at the working pressure or an air pressure test of not less than 50 psi for not less than 15 minutes (13). A third code requires a hydrostatic test of not less than 25 psi above the working pressure [14]. However, plumbing codes do not give guidance concerning solar systems which can contain liquids other than water. In these cases, hydrostatic testing of the system at $1-1 / 2$ times the maximum is considered to be appropriate[15]. "Dead-Weight" Cesters are frequenty used to callbrate pressure gages[16].

The maximum recommended operating pressure is 20 PSI. See attached test results for operation at elevated temperature and pressure. 
CALPAC

TEST RECORD

Contract \#NAS8-32253

Project: Collietratrat

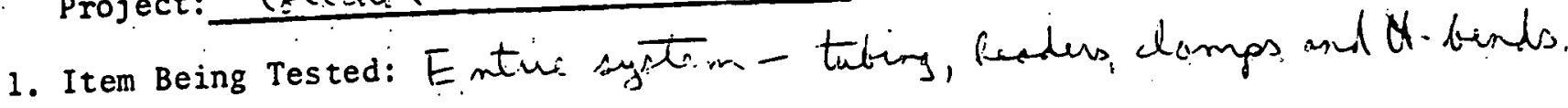
$2.3,1+5,2,4$

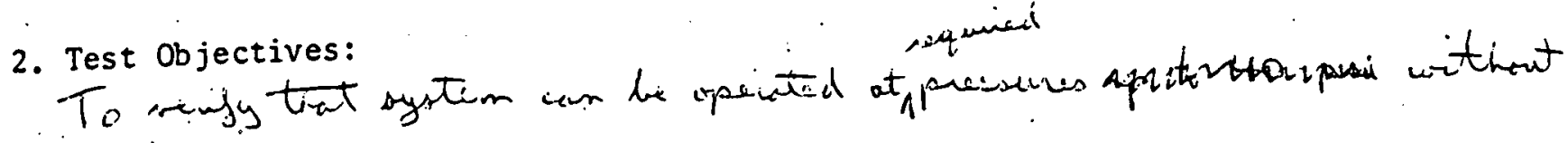
listing.

3. Location of test facilities and schedule .1 test dates:

CithAC Jat in: Mont 2 -Math 30 .

4. Prerequisites for Passing or Failing:

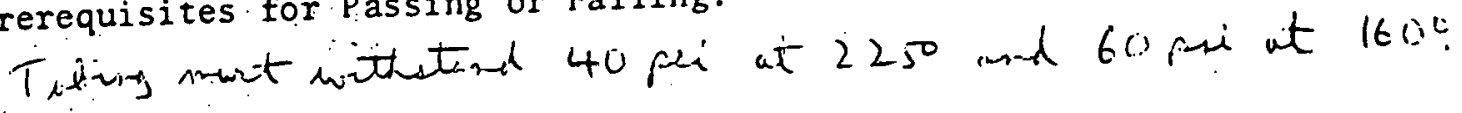

5. Test Procedures:

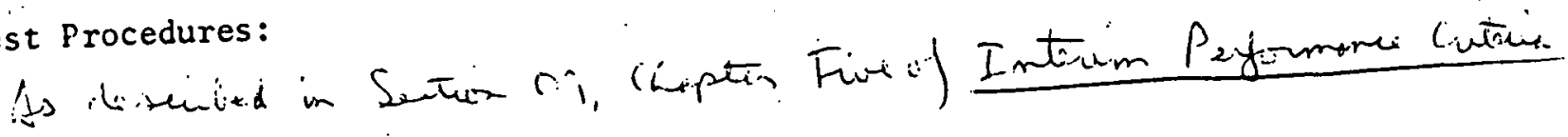

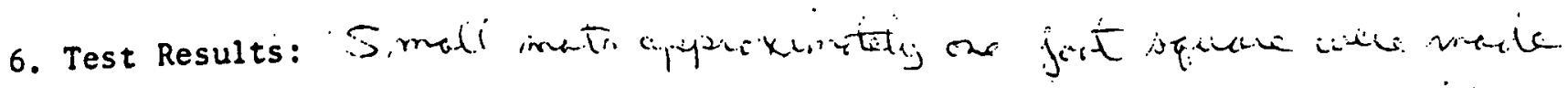

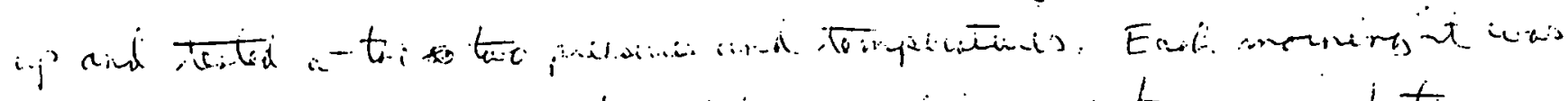

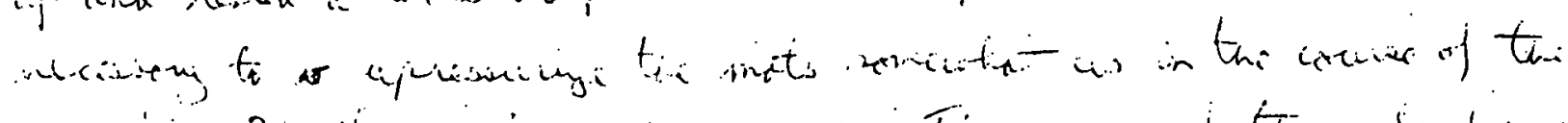

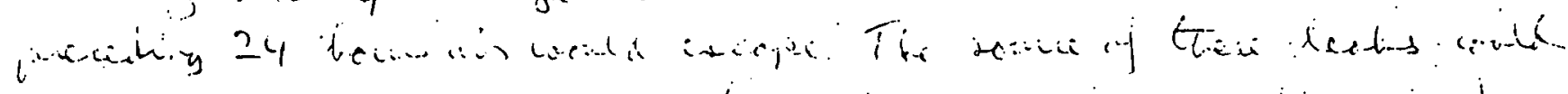

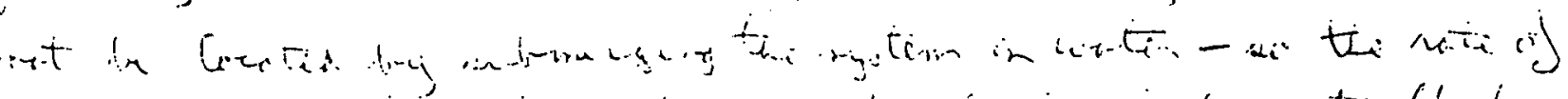

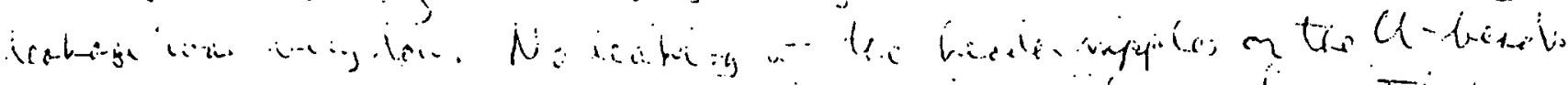

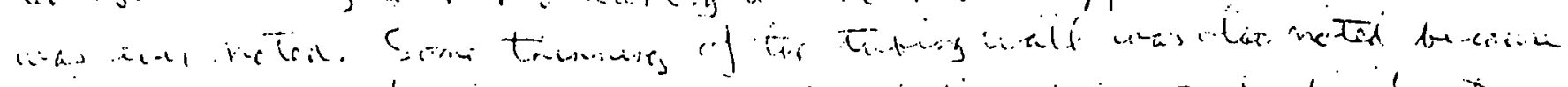

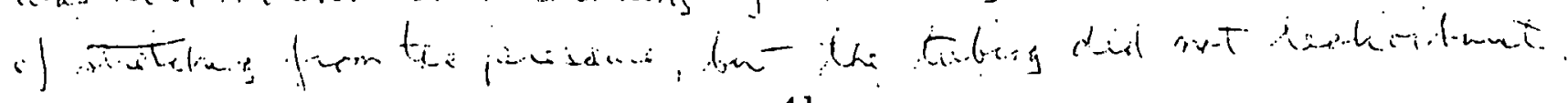

41 
lector adjustments. The collector subsystem shall be capable of

renced, and $t 11$ ted as requlted by clice destin to captur. being located, orlenced, and tilced as renal requiremellts. suffictent solar energy

\subsubsection{Criterion}

taining the design tilt and orientacion.

Evaluation Review of drawings and specifications.

Commentary

alther be flxed, rèquire seasonal adjustment or be Collectors can elther be flxed, requireation cunceruing orientation continuuusly novable. Detailed lntormatiot the intent of this criteriull and $t 11 \mathrm{l}$ is given in ASHRAE[17). It Is noted or cllted after lnitid that the collector necessarlly be $r$ installation.

The collectors must be mounted on some underlying surface--a roof or plywood frame, for example. They are not self-supporting to the extent that a $2 \times 4$ or pipe frame alone could be used to support them.

2.6.4 Criterion Freezing protection. Heat transfer liquids shall be prevented from freezing at the lowest amblent temperatures that w111 be encountered in actual use where such freezing would impair the function of the system.

Evaluation Review of drawings and specifications.

Commentary. The purpose of this criterion is to insure that rupture or other damage to solar collectors and associated piping and equipment will not occur from expansion of water if it freezes. The intent of this criterion is not to restrlct the designer to the use of antifreeze solutions.

The use of glycol antifreezes will not damage the collector in any way. EPDM hose is commonly used in automtive radiator systems. 

system design, combination cemperacuressure reducing valves, and/or oeparate pressure rellef be provided. atmospheric vents shall be Review of drawings and specifications.

Commentary This criterion is intended to prevent safety haza inadequate pressure and temperature procection.

A relief system opening at $210^{\circ} \mathbf{F}$ or 20 PSI is required in the system, and is called for in the Installation Manual.

3.1 Requlrement structural design basis. The structural design of the heating (H), combined heating, and cooling (HC) and domestic hot water (DHW) systems including connections and supporting structural elements shall be in with nationally recognized codes and standards and shall be accordance with nationally recognised codvice life of the systems. based on loads anticipated during the service

\subsubsection{Criterion} Applicable standards. The structural desien and construction of and Dilk systems including connections and

Conventional elcments* shall comply with the provisions of the HUD Minimumeperty Stanclards (MTS)[1] for single family and multifamily Minimum Propers 119.114$]$, In the case of mob1le homes, and such addihousing or ANSI Alla.1Llf, in the case of mapter. Non-conventional tional criteria as specifled in this chapteria stipulated in this chapter. elementsk shall comply with all the criteria stipulaced in this

Evaluation

Review of drawings, spectfications ald structural calculations.

Commentary

In addition to coinplying with the design and construction provisions of the MPS or Ai:S1 A19.1 (for mobilc homes), conventional elements and connections are required to comply with Criteria 3.1 .2 (Service loads), 3.2.2 (Ice loads). 3.2.3 (Vehicular loads), 3.5 .1 (Deston provisions

cutting of structural elements). 3.7 .1 (Hail st
3.9 .1 (Design provislous - ponding conditions).

See $3.1 .2,3.2 .1,3.2 .2,3.2 .4,3.3 .1,3.4 .1,3.7 .1$, and 3.9 .1 

design of conventional and non-converitional elements and connections of $\mathrm{H}, \mathrm{HC}$ and DHW systems:

1. Dead loads (D) shall be the "Destgn Dead Loads" stlpulated In Section 601-3 of the NPS.

2. Live loads (L) shall be all applicable 'Design Live Loads' otipulated in Section 601-4 and "Snow Loads" stlpulared in Section 601-5 of the MPS.

3. Wind loads (W) shall be "Wind Loads" st Ipulated In Section 601-6 of the MPS. In all cases conslderation of local wind conditions shall be assured by compllance with Section 6.3.3 of ANSI A58.1[2].

4. Earthquake loads (E) shall be those st 1pulated in Section 601-9 of the MPS which references the provisions of the Uniform Bullding Code (LBC) [3]. For non-conventional system components and connections, the value of " $C p$ " used in the UBC shall be taken as 2.0 .

1. Dead load equals the system's own weight, which is about 2.5 pounds/
quare foot. $D=2.5$ PSF

2. $L=20$ PSF per section 601-5 of the MPS.

3. $W=1.25 \times 15 \mathrm{PSF}=19 \mathrm{PSF}$ per Section 601-6 of the MPS.

4. $\begin{array}{rlll}E & =2 \times I \times C_{p} \times S \times W_{p} & I=\text { Importance factor }=1 \\ & =1 \times 1 \times 2 \times 1 \times 2.5 & Z=1 \\ & =5.0\end{array}$

$S=1$, where $C_{p}=2$

$W_{p}=2.5$ (Weight per squre foot)

This criterion simply established service load the collector's ability to meet these loads is covereds. Analysis of
criterion. 
5. Constraint loads caused by the envirunment, normal cunctioning of the system and time-dependent changes within the materials of the system shall be taken as the most severe likely tu be encountered during the service life.

6. Constraint loads induced by differentiai ioundation settlement shall be taken as rhose corresponding to a difierencial foundacion setcl. ment of the magnitude stated under Criterion 3.8.1.

7. Ice loads (I) shall be taken as those produced by the accumulation of ice on surfaces exposed to the natural environment. The thickness of ice shall be determined in accordance with Criterion 3.2.2.

8. Hail loads (H) shall be caken as those produced by the impact of hall on surfaces exposed to the natural environment. Hail particle slze and kinetic energy at Impact shall be determined in accordance with Criterion 3.7.1.

9. Vehicular loads on below grade installations shall be determined in accordance with Criterion 3.2.3.

Evaluation

For experimental or analytical evaluation of structural response, the the least margin of alfety to the system but consigtent with 1 to 1nteraction with structural ayatems to which they are atcached. Test loads applied to the bystem components shall result in the most crit $16 a l$ conditions encountered in service. Additional eccentricities of loadIng caused by drift due to lateral loads and anticipated differential foundation betrlements shall be provided for in tests of supporting structural elements of the system. The effects of service history caused by fatigue, sustained load, temperature, molsture, ultraviolet light or other environmental factors, shall be provided for in tests.

Commentary the intenc of the criterion is to state the required reliability of performance and, therefore, the specified loads should have a defined probability of occurrence.

The asoumption 16 made (w1th the exception of wind and snow loads, which are based on statistical analys1s) that the MPS "design loads" are loads anticipated during the service life of the system.

The minimum uniformly distributed live load on relatively flat horizontal and 1 nclined surfaces of the system is taken in accordance with roof loads prescribed by MPS. Snow load is based on ANSI A58.1 and is treated as live load in ileu of the MPS roof load if $1 \mathrm{t}$ produces a more severe loading condition. Th1s is consistent with MPS which UBes ANSI $A 58.1$ by reference.

Earthquake loada are determined by the applicable provisions of the Uniform Bullding Code. It is recognized that for cases lnvolving new materlal application it may be difficult to oclect the appropriate $C_{p}$ factor. The prescribed $C_{p}$ value intended for use withnonconventional elemente and connections is consistent with the values specifled in UBC for connections of exterior panels.

5. Neither the environment, normal functioning of the system or time-dependent changes are expected to exert loads approaching the loads i mposed by. such

6. See 3.8.1.

7. See 3.2.2.

8. See 3.7.1.

9. Vehicular loads do not apply as the collectors will not be installed below grade. 
Fallure loads and load capactiy. The structural elements and connections of the H, HC and DHW systems shall not fall under ultimate loads expected during the service life of the system.

3.2.1 Critertion Uitimate lond comblnations. Non-conventional elements and connectlons shall comply with this criterion. (Conventional elements and connections are deemed to satisfy this criterion.)

Structural components, connections and supporting elements shall be designed for the following ultimate load combinations:
(1) $1.4 \mathrm{D}+1.7 \mathrm{~L}$
(2). $0.9 \mathrm{D}+1.7 \mathrm{~W}$
(3) $0.9 \mathrm{D}+1.45 \mathrm{E}$
(4) $1.1 \mathrm{D}+1.3 \mathrm{~L}+1.7 \mathrm{~W}$
(5) $1.1 \mathrm{D}+1.3 \mathrm{~L}+1.45 \mathrm{E}$

where the mulclpllers are load factors and the letters are the service loads defined in Criterion 3.1.2.

Evaluation Review of structural calculations, specifications and drawings.

Commentary. The intent of the criterion (along with Criterion 3.2.4) 1s to provide a minimum level of safety agalnst loading situations which have a sultably low probability of occurrence during the service life. The load factors represent present-day design practice for building structures and are similar to the load factors used in ACI 318[5]. These factors w11l produce ultimate loads comparable to those presently used in the design of steel structures. Adoption of similar levels of performance requirements for the $\mathrm{H}, \mathrm{HC}$ and $\mathrm{DHW}$ systems will also permit the designer to explore the potential use of system components as structural elements for purposes of providing enclosure or diaphragm rigldity to the supporting structure in addition to their.primary heating and/or cooling function.

(1) $1.4 \times 2.5+1.7 \times 20=37.5$

(2) $.9 \times 2.5+1.7 \times 19=34.6$

(3) $.9 \times 2.5+1.5 \times 5.0=9.5$

(4) $1.1 \times 2.5+1.3 \times 20+1.7 \times 19=61.9$

(5) $1.1 \times 2.5+1.3 \times 20+1.5 \times 5=36.0$ 


\subsubsection{Criterion Ice Loads.}

(8) Above-ground installations of conventional elements for which ultimate design provisions apply, and of all non-conventional elements, including connections and structural supports thereof, shall comply. with Criterton 3.2.1 for load combinations (1) and (4) In which ifve load (L) shall be taken as that produced by the accumulation of Ice on all surfaces exposed to the natural envị ronment.

(b) Above-ground installations of conventional elements for which working stress design provisions apply, including connections and structural supports thereof, shall comply with Criterion $3.2 .2(a)$ with the following modification: load factors in load combinations ( 1 ) and (4) of Criterion 3.2 .1 shall be taken as 1.0 .

The radial thickness of ice around the c1rcumference of exposed wires, plpes, and structural members shall be based on the annual frequency of occurrence of glaze shown in Figure 3.2 .2 (see reference [6]) and shall be computed as follows:

$\begin{array}{lcccc}\begin{array}{l}\text { Mean annual number } \\ \text { of days with glaze }\end{array} & \text { under } 1 & 1-4 & 4-8 & \text { over } 8 \\ \begin{array}{c}\text { Thickness of Ice } \\ \text { (inches) }\end{array} & 0 & 1 / 2 & 3 / 4 & 1.0\end{array}$

Evaluation Review of structural calculations.

Comentary The intent of this critertion is to account for the effect of lce loads primarlly on wires, pipes and other simllar components which are exposed to the natural environment, In recognition of the fact that ice storms have been particularly detrimental to such components In the past.

The map of Figure 3.2.2 with documented information of the accumulation of tce recorded for major lce storms [6] and 1ce loads considered in the design of steel transmission pole structures [7] have been ut 111zed to relate thickness of 1 ce to frequency of occurrence of such storms. This assumption is made in view of a lack of statistical data on accumulation of 1 ce and should result in a generally conservarive practice even though it is recognized that thickness of 1 ce cannot be solely expressed in terms of rate of occurrence.

l" Thickness of ice equals $1 / 12$ of a cubic foot, which weighs 62.4 pounds, so
$1 / 12$ equals 5.2 pounds. $L=5.2$

(1) $1.4 D+1.7 L=1.4 \times 2.5+1.7 \times 5.2=12.3$

(2) $1.1 D+1.3 L+1.7 W=1.1 \times 2.5+1.3 \times 5.2+1.7 \times 19=42$

42 PSF is less than the 75 PSF load tested in Criterion 3.3.1. 
Load Capacity. Non-conventional elements and connectlons shall comply. with this criterion. (Conventional elements are deemed to satisfy this criterion.)

The load capacity, $R$, of the system or a portion thereof shall exceed the required ultimate load, U, In Criterion 3.2.1 and shall be derived from the mean load capacity $R_{m}$ :

$$
U \leq R=R_{m} \emptyset c_{u}
$$

where:

- varlability factor which shall be such that approximately 95\% of the system or portions thereof exceed $R_{m} D$ in resistance. For normal distribution of resistance, $\theta=1-1.65 \mathrm{v}$.

$v$ - coefficient of variation of resistance with respect to $R_{\mathrm{m}}$.

$c_{u}$ - coefflctent for ductility $=(\mu+7) / 12$, but not more than 1.0 for loadings not including earthquake, and equal to 1.0 for loadings including earthquake.

W ductility factor for loading condition $U$, as defined under Evaluation below.

Evaluetion

Where adequate existing cest data on the varlous materlal properties comprising the system are avallable, evaluation will be performed using engineering analygis. Where adequate cest data is unavallable, aygtem elements and subagsemblies will be evaluated in the laboratory using -1mulated static load levela consistent with the specifled load combinat1ons.

The duct1lity factor w1ll be evaluated as follows: For an 1deal elastoplastic (elastic-perfectly plagtic) resistance function (plot of applied load as ordinate and deflection as absc1sas), the ductilleg. factor 19 defined as the racto of ulelmate deflection to yleld deflection $\left(\mu-d_{u} / d_{y_{0}}\right)$. For an actual (nonlinear) function, the duct1l1ty factor shall be computed from an "effective" function (F1g. 3.2.4). The - ffective function consiats of 2 stralghe lines. The first line 18 drawn through the origin and a polnt on the actual function at which the resletance 1860 percent of 1 ts maximum load value $\left(P_{u}\right)$. The becond 110i 18 a hotizontal line ending at the ultimate deflection $\left(d_{u}\right)$, which ohall not exceed that where the resistance function falls below 95 percent of 1 ts maximum load value. The hortzoncal line 1s locaced so that the arsa under the $2 \cdot 11$ nes forming the effective function 18 equal to the area under the actual function up to the point of ultimate daflaction. Effective yleld deflection (dye) shall be taken as the deflection at the polnt of Intersection of the 2 l1neg, which is at a realstance level termed "effective yleld resistance." The ductility factor 1s based on the effective realocance function: $\mu=d_{u} / d_{y e}$.

Commentary The Intent of th1s criterion (along with Criterion 3.2 .1 ) 18 to provide - minimum level of afety against loading altuations which have a ultably low probability of occurrence during service 11 fe.

See 3.2 .1 

DHW systems shall be designed to withstand survice loads without damage of unacceptable magnitude.

3.3.1. Criterion

Evaluation
Resistance to damage. Non-conventional elements and connections shall comply with this criterion. (Conventional elements and connections are deemed to satisfy this criterion.)

Under the effect of deflections caused by loading combinations of (1), (2) and (4) of Criterion 3.2.1, with load factors of 1.0, in addition to the anticipated creep deflections, the system as a whole or any component, connection or support thereof, shall not suffer permanent damage which would require replacement or repair, or which would Impalr its intended function during its service life.

Evaluation of documented data for design, tests, and installation. Evaluation and/or testing of components and elements where deemed essential. Duturmination of compllance with generally accepted standards and englneering and trade practices, where applicable.

The critertion is deemed satisfied if it can be demonstrated that deflections caused by the specifled load combinations can be accommodated by sultable detalls or adequate flexibility.

Commentary The lntent of this criterion is to provide for the proper functioning of the system under service loading conditions without breakdown or permanent impalrment beyond levels comparable to conventional heating and cooling systems.

(1) $\mathrm{D}+\mathrm{L}=2.5 \cdot 20=22.5$

(2) $\mathrm{D}+\mathrm{W}=2.5+19=21.5$

(4) $\mathrm{D} \cdot \mathrm{L}+\mathrm{W}=2.5+20+19=41.5$

9" of sand weighing 100 pounds per cubic foot was loaded onto a horizontal collector was inspected for damage and $2 \times 4 \mathrm{~s}$. After. removing the sand the The effective load on the collector was none was noted. See test results. 
CALPAC

TEST RECORD

Contract \#NAS8-32253

Project: Collector

1. Item Being Tested: Entire allecton

$$
3,3,1
$$

2. Test Objectives:

To verify ruggedness and durability of the collector struative.

3. Location of test facilities and scheduled test dates:

CAL MAC factory, Mach 15- Apis 15"

4. Prerequisites for Passing or Failing:

Part I: Collector should withstand 41.5 psf pressure.

Part II: Residual deflection shall not exceed 25\% of the maximum deflection measured in the first cycle of hood application.

5. Test Procedures:

Pit I: 1) Place a piece of 3/4" plywood 4' $88^{\prime}$ on top of a 4' 8 ' collector.

2) Keep adding weight to te plywood ency across its suffice untie the

- collector begins to collapse.

Pat II: 1) Mount a 2'، 4' collector section upside down.

2) At the custer if thegiazing Attach a weight which will exert a 12.5 pos prolix apcisist the perineth wall:

3) Cycle ti wert up and down once

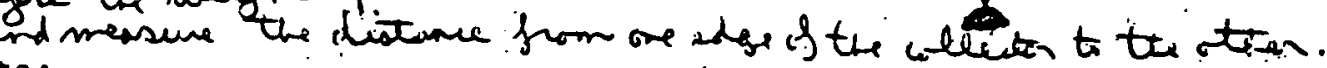

6. Test Results: 4) Cycle the weight 1000 tines and madame tho residual reflection of ton waiting 24 bows.

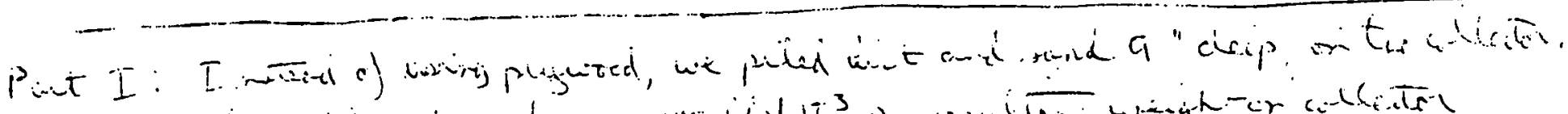

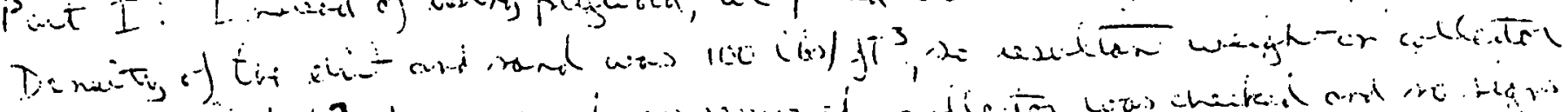

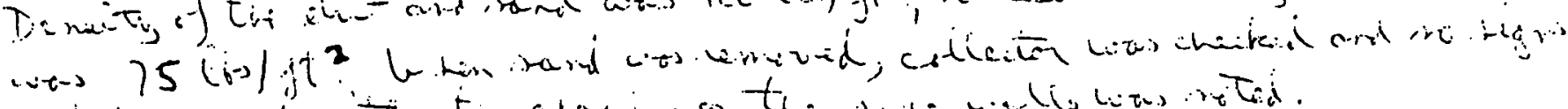

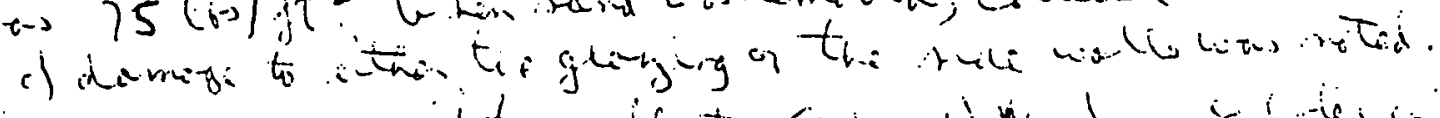

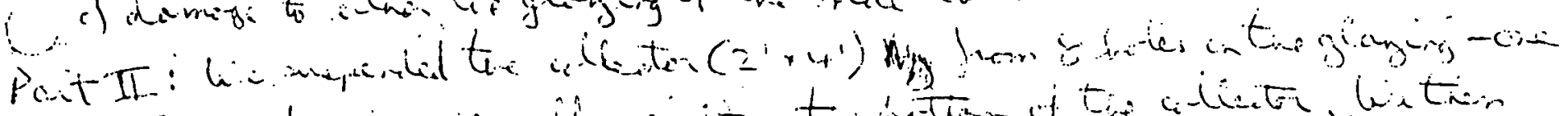

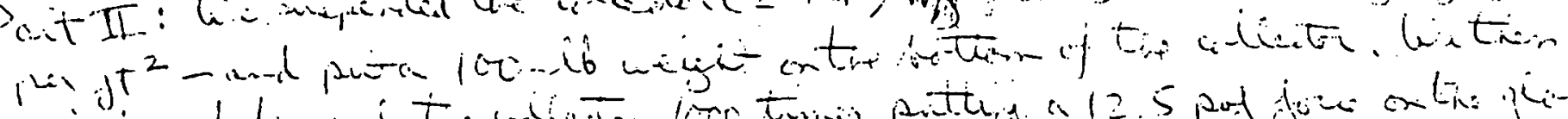

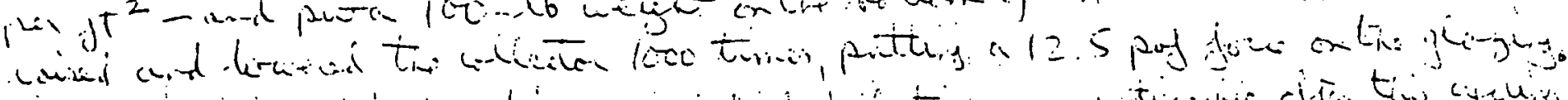

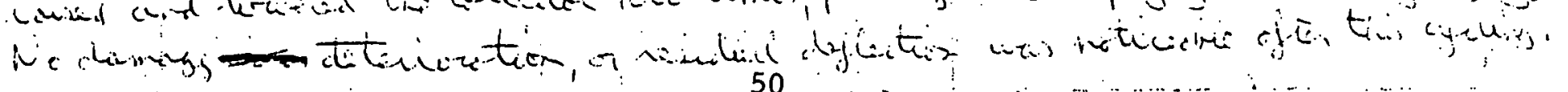


Contract \#NAS8-32253

Projecl: Collector

1. Item Being Tested:

$$
\begin{aligned}
& \text { Entire collector } \\
& \text { 3.3.1 (partial) }
\end{aligned}
$$

2. Test Objectives:

To verify ruggedness and durability of the collector.

3. Location of test facilities and scheduled test dates:

CALMAC Mfg. Corp. May 1-15.

4. Prerequisites for Passing or Failing:

Part I. Collector should withstand 41.5 psf pressure.;

5. Test Procedures:

Part I 1.) Build frame around collector, extending 8" above collector

2.) Build a $5^{\prime \prime}$ layer of sand(density $=100 \mathrm{lbs} . / \mathrm{ft}^{3}$ ) and let sit over night.

3.) Remove sand and check for any change in collector.

6. Test Results:

1.) Collector was loaded gradually up to 9 " of sand (75lbs./ft ${ }^{2}$ )

2.) After removing sand only a slight wave was noticed in collector surface.

3.) All sides walls and adhered areas were checked, with no signa of damage. 
Cyclic loads. The structural elements and connections of $\mathrm{H}, \mathrm{HC}$ and DHW aycters shall not fall under the application of cyclic loads expected during the service life.

3.4.1 Criterion

Deflection limtations. Non-conventional elements and connections shall comply with this criterion. (Conventional elements and connections are deemed to satisfy this criterion.)

Structural components, connectlons and supporting elements shall be capable of resisting the following repeated loads without fallure and without a resldual deflection in excess of 25 percent of the maximum deflection measured in the first cycle of load application:

(1) 100 cycles from $1.0 \mathrm{D}$ to $1.0 \mathrm{D}+0.5 \mathrm{~L}$.

(2) 1000 cycles from $1.0 \mathrm{D}$ to $1.0 \mathrm{D}+0.5 \mathrm{~W}$

\begin{abstract}
Evaluation Physical simulation and testing or analysis based on avallable test data.

The cyclic loading ( 1 ) and (2). shall be assumed to be applled after reducing system slack by the prior application of one preloading cycle of the following loads:

$$
\begin{aligned}
& \text { for (1) from (1D) to }(1 D+1 L) \\
& \text { for (2) from (1D) to }(1 D+1 W)
\end{aligned}
$$

Cyclic loading shall commence only after deflection recovery from the preloading cycle is substantially complete. The residual deflection shall be taken as the difference between the deflection measured 24 hours after removal of the superimposed cyclic load and the residual deflection, If any, not recovered from the preloading cycle.

Commentary Even though the service load history cannot be simulated the 1mposition of the stipulated cyclic loads is intended as a conservative representacion of service conditions. The residual deflection limitation assures preservation of structural integrity under cyclic loading.
\end{abstract}
(1) $D=2.5$
$D+.5 \mathrm{~L}$
$=2.5+.5 \times 20=12.5$
(2) $D=2.5$
$D+.5 W$
$=2.5+.5 \times 19=12.0$

A force of 12.5 PSF was exerted pulling against the glazing of a test collector for a thousand cycles and no damage or measurable residual deflection was noted. See test results.

This test was performed twice, once using a collector without a trim strip with the glazing cemented to the insulation board wall, and the other time using a collector with a trim strip with the glazing held in place with 
3.7.1 Criterion Ha1l size and loading. System components and supporting structural elements that will be exposed to the natural environment in service shall be designed to resist, without excessive damage or major impairment of the functioning of the system, the perpendicular 1mpact of falling hall having a particle dlameter (in lnches) equal to $0.3 \mathrm{~d}$ where $d$ is the mean annual number of days with hall determined on the basis of the hall map shown in Figure 3.7.1 [6].

Evaluation Evaluation will be based on analysis using known structural information on the physical characteristics of the system components or on physical simulation and testing using the NBS hall resistance test described in the NBS Bullding Sclence Series 23[9]. In the absence of physical test data, the portion of the kinetic energy dissipated by system components shall be taken as 50 percent of the kinetic energy at lmpact corresponding to the resultant velocity specified in Table 3.7.1 (reproduced from kef. [10]) for the predetermined hall size.

In cases where protective measures are provided to prevent 1mpact of hail on system components, such as the use of screens or deflectors, these protective measures shall he included in the test specimens.

Comment ary

It is not the intent of this criterion to prevent punching or local cracklng of nonstructural elements such as glass cover plates of collector panels under hall $1 \mathrm{mpact}$, but rather to control damage by keeping it at a level which would not create a major curtailment in the functioning of the system, premature failure or hazards created by excessive shattering of glazed elements.

The correlation of hall size with mean annual number of days with hall is based on studies on the probability of exceedance of a given particle size as a function of frequency of occurrence of hail, a twenty year recurrence Interval reflecting the life expectancy of the system and observations of statistical data (11) Indicating that a representative hallstorm area is generally one order of nagnitude smaller than the regions for which statistical information is complled.

7 The worts condition in the U.S. is 6-8 days/year (mean $=7$ days). $7 \mathrm{x} .3=2.1 "$ From Table 3.7 .1 the kinetic energy at impact for a $21 / 4 "$ ice sphere is 50.96 foot/pounds. $50 \%$ of that is 25.5 . Data from Kalwall shows it takes 25 to 32 foot-pounds to shatter the glazing. Fiberglass reinforced polyester is extremely resistrfat
to this type of stress. 
3.8 Requirement

3.8.1 Criterton

Evaluation

Commentary
Constraint loads. The structural elements and connections of $H, H C$ and DHW systems shall comply with Criterion 3.2 .1 while simultaneously subjected to constraint loads expected during the service $11 f$ e.

Foundation settlement; contraction and expansion. Non-conventional elements and connections shall comply with this criterion. (Conventional elements and connections are deemed to satisfy this criterion.)

System components, connections and supporting elements shall comply with Criterion 3.2.1 while simultaneously subjected to the following constralnt conditions:

1. A differential foundation settlement of 2 inches in any horizontal distance of 50 feet except that in cases where che foundation at a particular site is specifically designed to control differential settlements, the constraint conditlons should be those consistent with the specifled design. Uplift forces caused by a swelling of expanslve solls shall be calculated assuming a level of $0.9 \mathrm{D}$ for gravity loads.

2. Constraint loads arising from thermal expansion and contraction of aystem components and structural elements or from clme-dependent changes within the material.

Analysis and/or physical simulation.

Soll-structure Interaction 1s usually a design function since conatra1nt loads are dependent on the characteristics of the soll es well as the effects of structural framing. Due to economic consideraclons in foundacion design, the assumption is usually made that the superstructure is capable of accommodating a reasonable amount of differential setclement. The requirement in part (1) is consistent with observed perforinance of conventionally designed foundations and represents the threshold at which structural damage occurs. This criterton is relaxed when special precautions are used in foundarion design to control differential settlements.

The raquiraments in part (2) of the criterfon accounc for other types of constralnt loads auch as those introduced by thermal expancion and contraction of system components or creep and shrinkage in supporting otructural elaments.

Stress created by foundation settlement will be absorbed by the ability of the collector to flex to s small degree. The absorber tubing, insulation and frame pieces can all withstand slight bending and flexing.

Stress created by differential expansion between the collector and its supporting structural elements can be absorbed partly by the ability to flex as described above, and also by proper mounting procedures. 
3.9 Requirement

3.9 .1 Criterion

Evaluation

Commentary
Pondlug condition:. Horlzontal surfaces of the H, IIC and DHW systems shall be designeú in a manner that will assure stabllity in service under ponding coiidltions.

Dealgn provisions. Horizontal surfaces exposed to the extertor env. ment shall be designed to have elther sufficlent stiffness to prevent fallure as a result of ponding caused by the accumulation of water or shall be provided with sufficlent slope to permit free dralnage or adequate individual drains to prevent the accumulation of water.

Analysis based on documented strength and stiffuess properties or physical simulation and testing.

Ponding is defined as the recention of water due to the deflection of horizontal surfaces. The lack of sufficient vertical stiffness causcs the surfice to concinuously deflect and accumulate additfonal water unt 11 collapse occurs.

The collector has a design minimum slope requirement of 2 in 12 . This allows water to run off the glazing. A test was performed to insure that at a 2 in 12 slope water would run off. See test results. 
CALPAC

TEST RECORD

Cont rect \#N AS8-32253

Project: Collector

1. Item Being Tested: Slanging and perimeter wall, and fond between the two, and spacer techs. 3.9 .1

2. Test Objectives:

To verify that at a 2 in 12 slope watt will mun off the collector.

3. Location of test facilities and scheduled test dates:

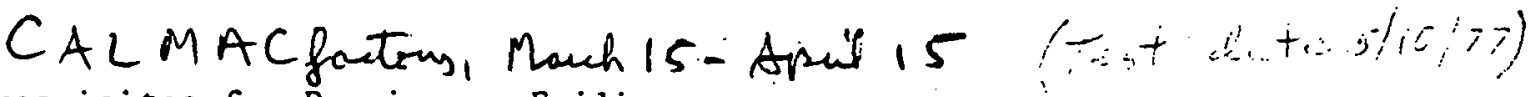

4. Prerequisites for Passing or Failiriz:

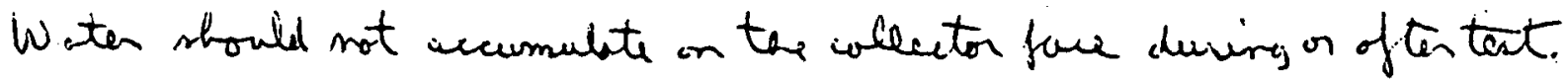

5. Test Procedures:

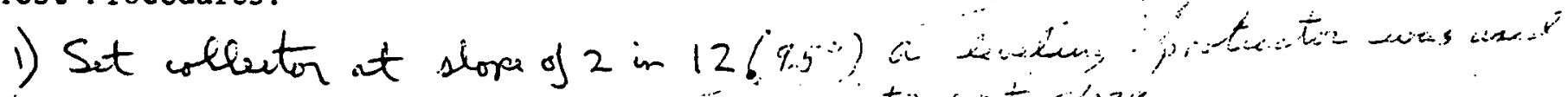

2) Sony vigorowly with wot. to sot

3) Time off watt.

4) Dotscuat Examine for any fording during and of ter spanging of water.

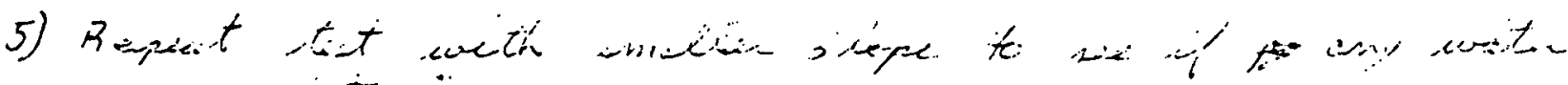
inccunculiti.

6. Test Results:

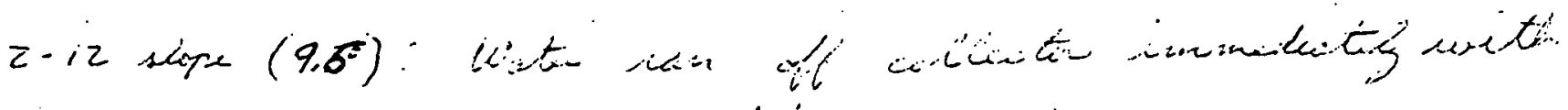

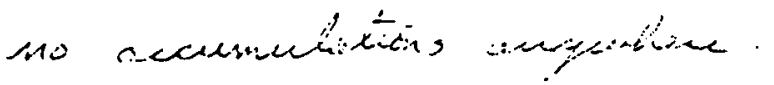

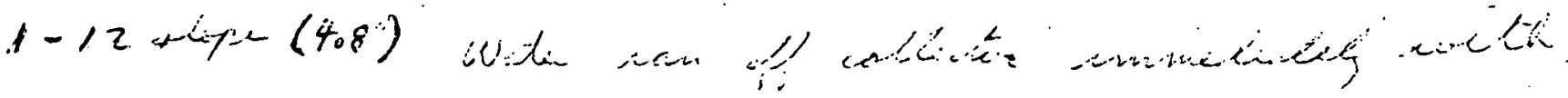

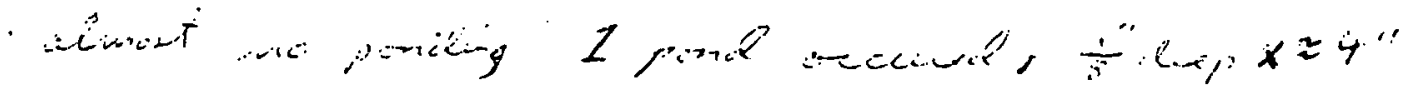

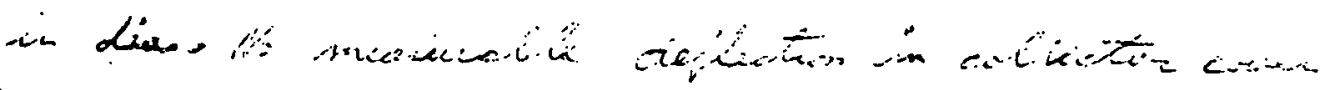

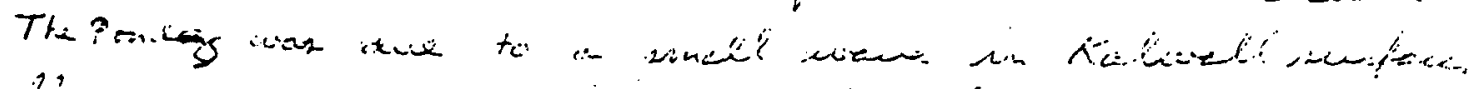

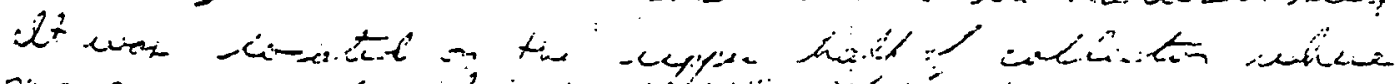

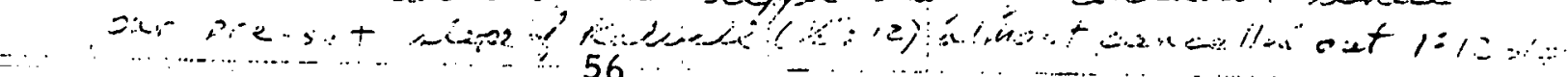


4.1 Requirement Plumbing and electrical installation. The design and 1nstallation of the systems for heating (H), combined heating and cooling (HC) and the domestlc hot water (DHW) system/subsystem and thelr components shall be in accordance: with nationally recognized plumbing and electrical codes and standards: for health and safety, where applicable.

\subsubsection{Criterion Plumbing codes and standards. Plumbing macerials and equipment and} thelr Installation shall be in accordance with Sections 515 and 615 of the MPS (4900.1 and 4910.1)[1] and Part C of ANSI A129.1[2], where applicable.

Evaluation Review of drawings and specifications. Teating to show compliance, where necessary.

Commentary Sultable standards are ava1lable for conventional equipment. Unique Innovative installations may require special consideration.

Al1 plumbing connections are standard. A review of the National Standard Plumbing Code did not indicate any areas where the collector would not be in compliance.

4.2 Requirement

4.2.1 Cricerion

4.2.1 Criterion

Evaluation

Commeneary
Fa1l-safe controls. The H, HC and DHW systems shall be fall-safe in the event of damage to system components or a power fallure.

System fallure prevention. The control subsystem shall be designed so that in the event of a power fallure, or a fallure of any of the com-
ponents in the subsystem, the temperatures and/or pressures developed in the $H, H C$ and DHW systems will not be damaging co any of the components of the systems, and the bullding, or present a danger to the occupants. The safety devices shall meet the requirements of section $515-6.4$ of the MPS $(4900.1$ and 4910.1$)[1]$.

Review of drawings, specifications and design calculations.

Perform test of fall-bafe control tnstallation for all probable faliure events.

The excessive pressures and temperatures that can bulld up in collectors under "no flow" conditions are an important consideration. Consideration should be given to the thermal shock which could occur when cool heat tranafer fluida are introduced inco collectora which have been exposed to oolar radiation under "no flow" conditions.

Fail-safe systems are called for and described in the Installation Manual but are not a part of the collector itself. Fail-safe tests were run using the recommended fail-safe devices. See test results. 
Contract \#NAS8-32253

Project: : Cellector

1. Item Being Tested: Fail-soji system festures $(4,2.1)$

2. Test Objectives: To verify that in the event of a power failure, or failure of any other components of the system, no damagewill result to the other components of the system or to the building and its occupants.

3. Location of test facilities and scheduled test dates: CAIMAC factory, Manch 15 - Ariti 15

4. Prerequisites for Passing or Failing: If the temperature/pressure relief valve opena at the prescribed temperature/pressure, the fail safe system will have passed. The test will be repeated several times for various combinations of temperature or pressure.

5!. Sest Procedures: The temperature/pressure relief valve will be set at 210 and 40 psi. Water pressure will be allowed to increase up to $40 \mathrm{psi}$ and beyond until the valve opens--the point at which it opens will be noted, and the test repeated several times to determine the variance. The same procedure will be repeated with by increasing the water temperature up to $2250 \mathrm{~F}$ and beyond until the valve opens-the point at which 1 opens will be noted, and the test repeated several $t$ imes to determine the variance.

\section{Test Results:}

The collector was allowed to stagnate for I hour (pump off) on a sunny day (insolation 250-270 BTU/hr/ft ${ }^{2}$ ). The pump was then turned on with valve closed at pump outlet and valve slowly opened. Collector outlet thermocouple temperatures adjoining releif valve were observed. Relief valve opened at 2100F. This was repeated for a total of three tests. Pressure relief valve was also tested by adjusting the pressure regulating valve up through 40 PSI from a lower pressure. Relief valve opened at 40 PSI on three separate tests. 


\subsubsection{Criterion}

Automatic pressure rellef valves. Adequately olzed and responsive automatlc pressure rellef valves shall be provided in those parts of the energy. transport subsystem contalning pressurized fluido. than 25 percent in excess valves shall be set to open at not less than 25 percent in excess of working pressure.and at not more than

Eveluation maximum pressure for which the subsystem 1s:designed.

Review of plans and apecifications, and/or devices, and waterials to be used are and/or determination that methods, devices, and waterials to be used are approved by recognized testing
and evaluation agency as being oultable for the proposed use.

See 4.2 .1 and accompanying test reaults.

4.3 Requirement Fire safety. The design and 1nstallation of the $H$, HC and DHW Bystems and thelr components shall provide a minimum level of flre safery conslatant with applicable codes and standards.

$$
\therefore
$$

4.3.1 Criterion Applicable fire standards. Asgemblies and the materlals used in the $\mathrm{H}$, HC and DHW systems shall comply with nationally recognized codes and otandards for flre safery, where applicable.

Evaluation Review of drawings and specifications for conformance with the MPS. ANSI Al19.1, and applicable sections of NFPA 89M[4], NFPA 90A and 90B[5], NFPA 211[6], NFPA 54[7], NFPA 31[8], ASTM E 108[9] and the National Electric Code [10]. Testing to show compliance, when necessary. Potential heat, rate of heat release, ease of 1 gnition, and smoke generation will be considered in assessing potential fire hazards.

Commentary It is the intent of this criterion to (1) prevent the use of materials, equipment and fluios which present a fire hazard significantly greater than that of conventional systems, (2) to provide proper clearances and venting of heat build-up for thosc system components that operate at elevated temperatures, and (3) to give consideration to the combustibility of materials adjacent to high temperature components in determining the clearances that are required. A review of the specifications for the materials used in the collector
indicates compliance with applicable fire standards. 

frated walls, partitions, floors, roofs, etc. shall not reduce the MPS (4900.1 and 4910 the level's specifled in Section 405 of the

Evaluation Review of drawtings and. where necessary.

Comentary

It is the intent of this criturtion (1) to prevent the passage of affecting the fire through fire-rated assemblies from adversely that proper techniques are rating of the astembly, and (z) to ensure so that adequate protection can be provided.

Nothing in the design of the system for mounting the collector affects the fire resistance of penetrations through the roof structure.
4.4 Requirement Toxic and flammable fluids. Heat transfer fluids which require special handling because of toxicity and/or flammabllity shall not be used unless the systems in which they are used are designed to avold exposing the occupants of dwellings to unreasonable hazards.

\subsubsection{Criterion Erovision of catch bas In::. Adequately slzed and protected catch basins shall be provided, when liquids requiring. special handilng are used, to collect and store the overflow from pressure rellef valves, Ilquids drained from the system when it is being serviced. potential leakage, and accidental drainage. \\ Evaluation Review of drawings and spectfications. \\ Commentary The leakage of toxic fluids into the ground could contaminate the ground water.}

Use of a catch basin to hold heat transfer fluids that may vent from the temperature/pressure relief system is called for in the manual for the collector. 

fluids which do not present at ambient temperatures. Heat transfer hazardous at the temperatures developed amblent temperatures may be

The use of a catch basin (4.4.1) provides evidence of overflow from the system. The use of a pressure gauge in the collector loop provides a means of identifying leaks in the system--if a leak develops pressure in the system will drop. The use of a pressure gauge is called for in the collector manual.

Protection of potable water and clrculated a1r. No material, form of conetruction, f1xture, appurtenance or 1tem of equipment shall be employed that w111 Bupport the growth of micro-organismo or introduce toxic oubstances, 1mpurities, bacterla or chemlcals into potable water and alr circulation aystem in quantities oufficlent to cause disease or harmful physiological effects.

4.6.1 Criterion Contamination by materiale. Materialo which come in direct contact with potable water ohall not affect the tasce, odor or physical quality and appearance of the water in an undesirable manner.

Evaluation Review of plans and specifications for compliance with the 1962 Edition of the Public Health Service Drinking Water Standarda [11].

See the attached certification from the tubing supplier. This particular formulation of tubing has been used in food-grade applications such as for the spout in a coffee vending machine.

Early production items, including those manufactured for NASA, were not made from tubing from this supplier and should not be used in potable water systems. A notice to this effect has been included in the manuals delivered with collectors made from non-certified tubing. 
December 6, 1977

\section{CERTIFICATION}

This is to certify that all of the ingredients used in EPDM compound E-809 are within the limitations prescribed by the Food and Drug Administration as listed in the Federal Register under paragraph 121.2562.

PAWLING RUBBER CORPORATION
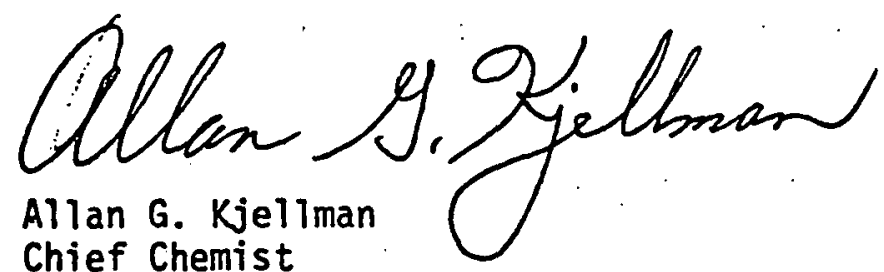

Allan G. Kjellman Chief Chemist 
4.6.3 Criterion Backflow prevention. Backflow of nonpotable heat transfer fluids into the potable water systems shall be prevented.

Evaluat1on

Review of drawings and speclfications. Inspection of assembled systems.

Comnentary

Pollution of the potable water supply can occur by way of backilo: caused by back pressure and/or backsiphonage within a cross conni:ttion between the potable supply and nonpotable fluid in the systrin. The former type of backflow can occur, for example, from elevated tanks, or pumps. The latter can. occur when the potable water silfply system is under vacuum such as might occur with a broken strentirater majin.

Piplng arrangements, backflow prevention devices, and/or alr gaps may be used to prevent contamination of the potable water system.

The use of check valves and double-walled heat exchangers is actively being discussed by HUD and the solar industry, and this topic is not explicitly covered in the collector manual. Nothing in the collector design affects the use of these items.

\subsubsection{Criterion Growth of fung1. Components and matisials used in the H, HC and illw} systems shall not promote the growth of fungi, mold or mildew.

Evaluation

When tested in accordance with Appendix D, Section E of the ITS (4900.1 and 4910.1)[1], there shouid bi no evidence of the growth $\mathrm{cf}$ fung1.

Comencary

Spectal consideration should be given to the presence of fungt in air handling systems since such micro-siganisms are frequently allergenic.

Fungl can feed on some organic materials and generally thrive li: warm, molst environments. They can be killed by sufficiently low wavelength ultraviolet radiation but much of this radiation may be absnrbed $b_{;}$ the earth's atmosphere. It may be posstble for fungt to grow on bisth the interior and exterior of collector components and possibly affect the collector performance.

Material specifications for the fiberglass insulation, where fungi would most likely grow, indicate resistance to this type of growth. Operation of collectors prior to and during the contract showed no evidence of growth of fungi either on the interior or exterior of the collector components. 
4.7 Requirement Excesalve ourface tempeitcures. Temperatures of exterlor surfacea of the H, HC and DHW systime shall not create a hazard.

4.7.1 Criterion Protection from heated components. Subassemblies of the $H$, HC and DliW systems that are accessible, located in areas normally subjected to public traffic. and which are maintalned at elevated temperatures shall elther be Insulated to. maintain the1r surface temperatures at or below $140^{\circ} \mathrm{F}$ at all times during their operation or suitably isolated. Any other exposed areas that are malntalned at hazardous temperatures shall be Identifled with approprlate warning s1gns.

Evaluation Review of drawings and specifications.

The collector is not likely to belocated in areas subjected to public traffic, and the glazing would only approach $140^{\circ}$ under
unusual situations. 
Effects of external environment. The systems for heating (H) and combined heating and cooling (HC) and the domestic hot water (DIiN) combined heattng and thetr various subassemblles shall not be affected by external environmental factors to an extent that will significantly impair their function during their design life.

\subsubsection{Criterion}

Solar degradation. Components or materials that are exposed to sunI1ght ghall not undergo changes in their propertles during their design life that would significantly impair the function of the system.

a. When components or materials are exposed to UV radiation in combination with an intermitcent water spray at their maximum "no-flow" temperature, there shall be no signs of excessive deterioration such as cracking, crazing, embrictlement, etching, loss of adhesion, changes in permeability, loss in flexural strength or any other changes that would significantly affect the performance of the components in the system.

b. The collector shall be capable of providing its rated output after exposure to levels and intensities of solar radiation and temperatures that are equivalent to those that would be expected in actual use over the life of the collector.

Evaluation

Documentation of satisfactory long term performance under in-use conditions or engineering analysis. Where adequate existing information is unavallable, testing using elther the methodology outlined in Section of the Appendix given at the end of this chapter or other methods which can be shown to meet the intent of the criterton w1ll be used.

Comentary

The transmittance, emittance and absorptance data required to estimate the effects of degradation by solar radiation in reducing the collecfficlency are avallable for most materlals currently being used in collectors.

The maximum "no flow" temperature and other in-use temperatures are discussed in detall in Section 01 of the Appendix at the end of this chapter.

Kalwall: See summary of testing done by Kalwall Corp.

EPDM Tubing: Samples were subjected to a four-month accelerated test on DSET's EMMAQUA (Equatorial Mount with Mirrors for Acceleration Plus Water) equipment and showed no signs of cracking, dimensional change, chalking or other deterioration. This test provided the equivalent of about $31 / 3$ years of normal exposure. One sample was under a single glazing of KALWALL.

CAL-ZORB: This particular material is $35 \%$ carbon black by weight, and is made of a base of urethane which has very good resistance to ozone, ultraviolet and heat-aging.

Noryl: See manufacturer's data package.

Complete Collector: See DSET results of testing in accordance with ASHRAE 93-77. 
Alrborne pollutants. Components that are exposed to alrborne pollusale spray, $\mathrm{SO}_{2}, \mathrm{NO}_{x}$, and/or $\mathrm{HCl}$ with or without the presence of molsture shall be resistant to attack by these factors to the extent that these factors shall not slgniflcantly
performance of the components during their design life.

Evaluation

Documentation of satisfactory long cerm performance under in-use conditions or englaeering analysis. Where adholology outlined in Section 1s unavallable, testing using elther the mis chapter or other methods 05 of the Appendix given at the end of this chapcer or ofher bill be used. which can be shown to meet the The maximum pollutant levelo in the area (a) wollutant levels required for Installed shall be used to determine the pols testing. If components are to be used ln areas whet are not applicexposed to any or all of the able need not be conducted.

Comentary

Ozone concentrations in normal dry alr have been reported to range frow 1-5 pphm/volume. However, concentracions of $100 \mathrm{pphm} / \mathrm{volume}$ have been reported during very amoggy conditions. Ozone loknown coterlals come organic mater other than metalo.

The ffecte of solar radiacion in combination with alrborne pollutant may also be an important consideration.

Kalwall glazing: See Manufacturer's data package.

EPDM Tubing: See data package on EPDM.

CAL-Zorb: See data package on Cal-Zorb and urethane.

Nory l: See manufacturer's data package.

Polyshim: See Manufacturer's data. This material is being used exactly as it was engineered to be used. The other materials are being used in non-conventional ways

\subsubsection{Criterion Dirt retention on cover plate ourface. The collector cover plate} surface hall not collect end reteln dirt to an extent that would algnificanty impatr the function of the collector during its design $118 \mathrm{se}$

Evaluation Englneer1ng analys18, documentation of sat1afactory long-term performance under in-use conditions and review of plans and specifications.

Commentary The possible collection and retention of dirt by the cover place and the effect of retalned dirt on the collector performance may be elgnificant. The retention of dirt may depend on the tile angle of the collector. Rainfall and snow melt are generally sufficlent to keep the collector cover plates clean.

The minimum recomended angle of installation is 2 in 12 . This angle alloss rainwater to run off and to keep the glazing clean. This requirement is spelled out in the collector manual. 
5.1.5 Criterion Abrasive wear. The ability of the collector to function at its rated capacity shall not be significantly impalred by the abrasive wear to which 1 to surface will be subjected over 1 ts design life.

Evaluation Engineering analysis, documentation of satisfactory long-term performance under in-use conditions and review of surface hardness opecifications for cover plate materinls.

Comentary Test methods which are currently avallable for measuring abrasion resistance are belleved to be too stringent for testing organic collector cover plates. Abrasive wear is expected to present a possible problem in areas subject to wind driven sand.

Some surface erosion of the Kalwall polyester glazing is expected, and resurfacing of the glazing every five to seven years is called for in the manual. See Kalwall's data package.

S.1.6 Criterion Fluttering by wind. Components that are subject to fluttering by wind shall not degrade under in-use conditions to an extent that their function will be impaired during their design life.

Evaluation Documentarion of satisfactory long-term performance under in-use. conditions, englneering analysis, or testing using an experimental verification procedure which can be shown to meet the intent of the criterion.

Comentary Thin films that increase in brittleness at low temperatures may be particularly susceptible to degradation by fluttering by wind.

Kalwall's resilience over a wide range of temperatures and over long periods of time is documented in the Kalwall data package.

The effect of fluttering on the bond between the Kalwall and the collector has been effectively tested in the testing of the collector's structural strength. See test results for 3.3.1. A 75-mph wind across the face of the collector was also created using a wind tunnel in the factory with no evidence of breakdown. See test results. 
CALPAC

Contract \#NAS8-32253

TEST RECORD

Project: Collection

1. Item Being Tested: Perimeter wall and gluzion and ford between the two. 5.1 .6

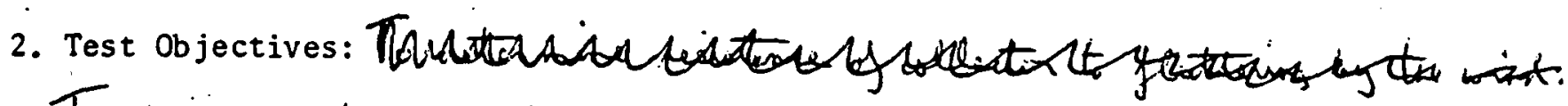
To measure fou e required to rip glairy anon from the insulation toad stuctineand determine esistame to flutteriors by the wind.

3. Location of test facilities and scheduled test dates:

CALMAC fiction, Mach 20-Apin 15

4. Prerequisites for Passing or Failing:

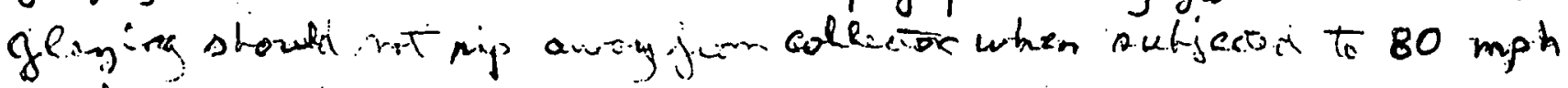
wind - intort sur in aju-Tio.

j. Test Procedures:

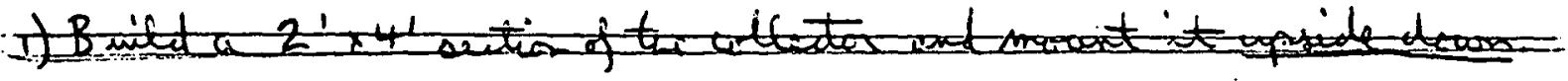

2)

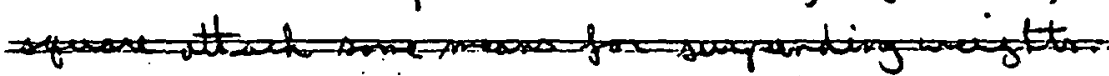

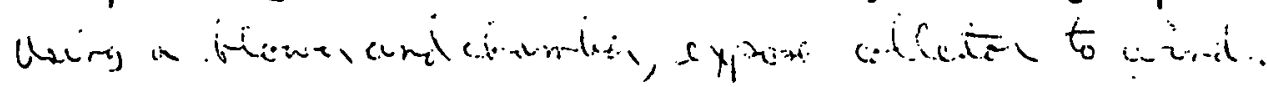

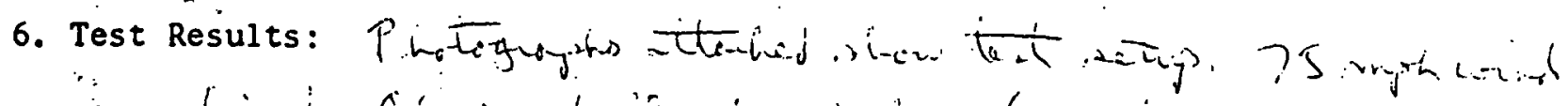

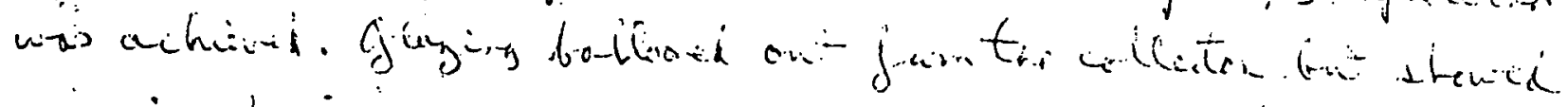

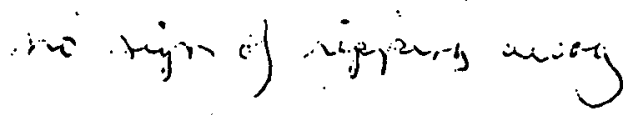

68 

performing their intended function for their design 11 fe when exposed to the temperatures and pressures that can be developed in the system.

.1 Criterion

Thermal degradation. Components shall not thermally degrade to the extent that their function will be reduced below acceptable levels during their design 11 fe when exposed to in-use temperatures.

Evaluation

Documentation of satisfactory long term performance under in-use conditions or engineering analysis. Where adequate existing information is unavailable, testing using either the methodology outlined in Section 06 of the Appendix given at the end of this chapter or other methods which can be shown to meet the intent of the criterion will be used.

Commentary

Some organic components which may be used in the system may be particularly susceptible to thermal degradation under prolonged exposure.

Kalwall glazing: See Kalwall data package.

EPDM: See descriptive data package on EPDM.Also see test results for Criterion 5.2.4.

Cal-Zorb: See data on Cal-Zorb. In addition, collectors using the adhesive have been stagnated at absorber temperatures clese to $300^{\circ} \mathrm{F}$ without deterioration.

Noryl: See descriptive data.

1300 Cement: See product specifications.

Fiberglass insulation: See manufacturer's specifications.

5.2 .2 Criterion

Evaluation
Deterforation of heat transfer flu1ds. Except when such changes are allowed by the design of the system, the heat transfer fluid shall not freeze, give rise to excessive precipitation, otherwise lose its homogene1ty, bo11, change $\mathrm{pH}$ or undergo large changes in viscosity when exposed to 1 to intended service temperature and pressure range.

Documentation of satisfactory long term performance under in-use conditions or engineering analysis. Where adequate existing information is unavallable, testing using either the methodology outlined in Section 07 of the Appendix g1ven at the end of this chapter or other methods which can be shown to meet the intent of the criterion will be used.

Thermal cycling may cause metastable precipitation to occur. Systems may be pressurized to prevent bo1ling.

Maintenance of the heat transfer fluid is called for in the collector manual. 

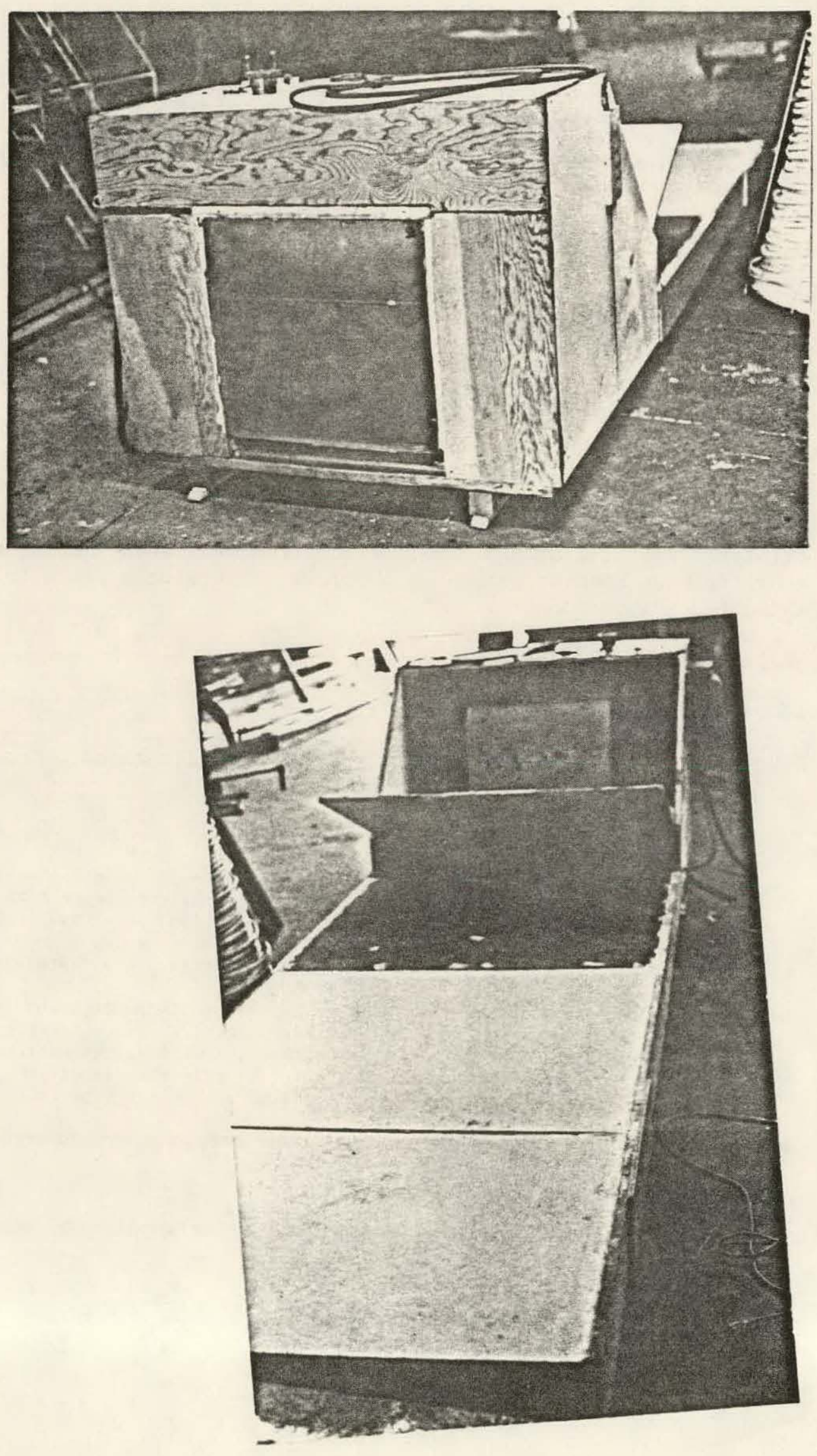


\title{
S.i.3 Critertion
}

Thermsl cycling gtresses. The H, HC and DHW systems and the1r various subassemblies ahall be capable of withotanding the etresses induced by thermal cycling for thelr respective design lives.

Evaluation Documentation of astafactory long term performance under in-use conditions or engineering analyols. Where adequate exiscing information 1s unavallable, testing using elther the methodology outlined in Section 08 of the Appendix given at the end of this chapter or other methods which can be shown to meet the intent of the criterion will be used.

Physical restraincs that w1ll be 1mposed on the aystem in actual use shall be considered when testing is required.

Cotumentary This criterion is intended to identify potential problems that may occur as a result of differential thermal movement. Thermal compat bility is especially critical in the case of collectors which may contaln large expanses of Blizing. Edge flaws in glass may result in cracking of the glass when 10 is under stress.

See $2 \cdot 2.5$

\begin{abstract}
3.2.4 Criterion Leakage. All assemblles or subagsemblies which contain heat tranefer flulds (other than alr) shall. not leak when tested at a pressure equal to $150 \%$ of the working pressure of the system over the entire service temperature range.
\end{abstract}

Evaluation Documentation of artafactory long term performance under in-use conditions or englneering analysis. Where adequate existing information is unavallable, testing using elther the methodology outlined in Section 09 of the Append1x glven at the end of this chapter or other methods whlch can be shown to meet the intent of the criterion will be used.

Commentary This critertion is intended for materials which may creep or become brittle at service temperatures.

See Test results for Criterion 2.3.1.

5.2 .5 Criterion

Detertoration of gaskets and sealants. Gaskets and sealants in direct concact with heat transfer 11quids shall be capable of withstanding repeated cycles consisting of soaking and drying under in-use conditions without significantly lmpalring their ability to function during their design life.

Evaluation Documentation of satisfactory long term performance under in-use conditions or engineering analysis. Where adequate existing information is unavallable, testing using efther the methodology outlined in Section 10 of the Appendix given at the end of this chapter or other methods which can be shown to meet the intent of the criterion w111 be used.

Commentary Gaskets, sealants, and simllar organic materlals frequently swell when exposed to liquids and shrink upon drying, thus losing their ability to function.

No gaskets or sealants other than a cement at the connection between the headers/U-bends and the tubing are used. This cement is an epoxy and does not absorb liquid or swe 11 in use. 
5.2.6 Criterion Trangmission losses due to outgassing. Outgassing of volatiles that will reduce collector performance below specifled design values shall not occur when the collector is exposed to the temperature and pressures that will occur in actual service.

Evaluation

Documentation of satisfactory long term performance under in-use conditions or engineering analysis. Where adequate existing information is unavallable, testing using either the methodology out lined in section 11 of the Appendix given at the end of this chapter or other methods whlch can be shown to meet the intent of the criterion will be used.

Commentary.

outgaseing from components inside the collector could lead to condensation on the underside of the collector.cover plates which may reduce the transmissivity of. the cover plates.

The organic binder in the rigid board fiberglass will vaporize to a certain extent at temperatures the collector might reach during stagnation $\left(250^{\circ} \mathrm{F}+\right)$. This problem was experienced during testing. By outgasing the insulation in an oven at $350^{\circ} \mathrm{F}$ for an hour the organic material that outgases at these temperatures is driven off. Since initiating this practice no problem with outgassing has appeared.

5.3 Requirement

Chemical compatibility of components. Materfals used in the bystems and their varicus subassemblies shal: have sufficient chemical compatibility to prevent corrosive wear and deterforation that would significantly shorten the intended service life of components under inuse conditions.

5.3.1 Criterion Materials/transfer fluld compatibility. Materials designed to be used in contact with heat transfer fluids shall not be corroded by these fluids to the extent that their function will be significantly impalred under in-use conditions during their intended service lives.

Evaluation Vocumentation of sat18factory long term performance under in-use conditions or engineering analysis. Where adequate existing information is unavallable, testing using elther the methodology outlined in Section 12 of the Appendix given at the end of this chapter or other methods which can be shown to meet the intent of the criterion will be used.

Commentary Corrosion, by heat transfer flulds could be a serlous problem in solar energy systems.

The only. two components in contact with the heat transfer fluid are the copper headers/U-bends and the EPDM tubing. Copper is used extensively in the collector field and has been proven to he compatible with water and glycol mixtures. The EPDM tubing is used in the automotive industry as radiator hose where glycol antifreeze is commonly used, and no chemical incompatibility. has been noticed. 
5.3.2 Criterion Corrosion of dissimilar materials. Non-1solated dissimilar matertals with or without corroyion resistant finishes, where used either in with or without cortodich aluld, or without such contact, shall not be corroded to the extent that thels function will be significanty lmpalred under in-use conditions during their intended service lives.

Evaluation

Documentation of satiafactory long term performance under in-use conditions or engineering analyols. Where adequace existing information 18 unavallable testing using elther the methodology outlined in Section 13 of the Appendix given at the end of this chapter or other methods can bhown to meet the incent of the criterion will be used.

Commentary

The use of corroaion Inhibicora or dielectric fittinga that electri100late diasimilar material.s may be desirable. In the caut of plasica, plasticizer migration may le a concern. The presence of pinholes in protective costingo may drastically accelerate corrosive action.

Copper is the only metal used in the collector, so there are no cases of dissimilar metals which might corrode through galvanic action.

All the other materials are plastics and elastomer: which have shown no evidence of corrosion or chemical interaction during the months of testing and use.

The $60 / 40$ solder used in the copper headers is designed specifically for use with copper to avoid corrosion.

\subsubsection{Criterion Corrosion by leachable subatances. Chem1cal subatances that can be leached by moloture from any of the materialo within the system shall not cause corrosive decertoration of any other componencs that would olinificantly impalr the ability of these components to perform their incended function over thelr service lives.}

Evaluation

Documentation of satisfactory long term performance under in-use conditions or englneering analysis. Where adequate existing information is unsvallable, testing using elther the methodology outlined in Section 14 of the Appendix given at the end of this chapcer or other methods which can be shown to meet the intent of the criterion will be used.

Commentary Salts such as those that can be leached by molature from some types of glase fiber and mineral wool insularion or from organic componants may cause cortosion of system components that are in close proximity.

The fiberglass insulation board meets military specification MI 244 for leaching, which allows only an extremely low amoung of leaching. No leaching has been seen during testing or operation.

See Criterion 4.6 .1 for leaching of the EPDM tubing. - 
that are expelled from components under in-use conditions shall nor cliat are expeladation of other components within the system to the extent that it would significantly impair their ability to perform their intended function over their service lives.

Evaluation

Documentation of satisfactory long term performance under in-use conditions or engineering analysis. Where adequate exlsting information is unatloble, resting using either the methodology outlined in Section 15 of the Appendix given at the end of this chapter or other methods which can be shown to meet the intent of the criterion will be used.

Commentary

Some components may yleld degradation products during their service $11 \mathrm{fe}$ without impairing their function or aesthetic properties. These degradation products could significantly impair the performance of other components in the system.

Outgassing from the insulation board did condense on the glazing but did not cause any degrading of any components. The outgassing has been handled by factory outgassing prior to assembly. See Criterion 5.2.6.

In early use the EPDM tubing may tend to give up small pieces of sediment. To remove this sediment, a filter in the line is recommended in the collector manual.

6.1. Requirement Accessib1lity for maintenance and servicing. The systems for heating (H) combined heating and cooling (HC) and the domestic hot water (DHW) gyetem/subsystem shall be designed, constructed, and installed to provide sufficient access for general maintenance, convenient servicing and monftoring of system performance.

Access for system maintenance. All individual ttems of equipment and components of the $H, H C$ and DHW systems which may require periodic examination, adjusting, Gervicing and/or maintenance shall be accesalble for inspection, service, repair, removal or replacement without disman. tling of any adjolning major plece of equipment or subsystem.

Evaluation

Review of drawings and specifications.

Commentary

Accessibility as a function of component life is an important consideration.

Information on access provisions is provided in Reference [1].

Access to the collector absorber system, which is the only component that might require service; is facilitated through the zipper-lock construction of the panel collector. The glazing can be popped off and pulled back easily to allow repair of the tubing. In the field assembled. design the glazing can be cut away from the insulation with a knife and then recemented after repairs are made. 
6:1.2 Criterion Access for system monitoring. Approprlate access for sensors shall be provided for inspecting and checking essential system parameters such as temperature, pressure ind critical voltages.

Evaluation. Review of drawings and spectflcations for the location of test fittings.

Commentary Adequately located test fittings w1ll permit system monitoring and expedite the malntenance and repalr of equipment.

The collector sensor for the differential thermostat can either be inserted in the header or can be clamped onto the header.

\subsubsection{Criterion Draining and f1111ng of 11quids. To fac1l1tate system or subsystem arintenance and repalr, subsystems employlng liquido shall be capable of belng conveniently filled and drained. \\ Evaluation Review of drawings and specifications. \\ Commentary. The potential bulfdup of vapor which could create alr pockets ard thus block or restrict the flow of heat transfer flulds should be consid- ered. (See Critertion 2.1.5)}

Complete draining of the EPDM tubing is difficult because of capillary action. To enpty out the tubing completely air must be pumped through the system. Complete draining, however, is rarely necessary as there is enough flexibility in the tubing to absorb expansion caused by freezing.

\footnotetext{
6.1.4 Criterion Flushing of liquid subsystems. Sultable connections shall be provided

Evaluation Review of drawings and spectifications.

Commentary The recommendations of the system manufacturer for cleaning agents compatible with the materials of the system should be followed.
}

Water is the recommended agent for flushing. See the collector manual.
6.1.5 Cricerion
Flleers. Filters shall be designed and located so that they can be cleaned or replaced with minimum distuption to the system and adjacent equipment. Cleaning frequencies sh:il lie speciffed by the system manufacturer in the maintenance manual.
Evaluation Review of irawings and specifications.

The use of a filter is recommended in the collector manual. See Criterion 5.3.4. 


\subsection{Requirement}

\section{2 .2 Criterion}

Installation, operation and maintenance manual. A manual snatl de provided for the lirisallation, operation and maintenance of the $H$, HC and DHW sysecms.

Installation Instructions. The manual shall include physical, functional and procedural Instructions describing how the subssemblles of the ...., HC and DHW systems are to be installed.

These instructions shall lnclude descriptions of both Interconnections between the system subassemblies and their interfaces and connections with the dwelling and site.

Review of Installation instructions.

\section{See the collector manual.}

\subsubsection{Criterion}

Evaluation
Maintenance and operation instructions. The manual shall completely describe the H, HC and DHW systems, their breakdown into subsystems, their relationstip to external systems and elements, their performance characteristics, and their required, parts and procedures for meeting specifled capabilities.

The manual shall ilst all parta of the systems, by subsystem, describing as necessary for clear understanding of operation, maintenance, repuir and replacement, such characteristics as shapes; dimenslons, materials, welghts, functions and performance characteristics. The manual shall include a tabularion of those specific performance requirements which are dependent upon opecific malntenance procedures. The malntenance procedures, Including ordinary, preventive and minor repa156, shall be crosi-referenced for all subsyatems and organized into a malntenance cycle. The manual ahall fully describe operation procedures for all parts of the system including those required for implementacion of opecified planned changes in mode of operation.

Review of maintenance and operating instructions.

See the collector manual.

\subsubsection{Criterion}

Maintenance plan. The manual shall include a comprehensive plan for maintaining the specifled performance of the $H, H C$ and DHW systems design service lives.

The plan shall include all the necessary ordinary malntenance, preventive maintenance and minor repalr work and projections for equipment replacement.

Evalwation Review of malntenance plan.

Sfe the collector manual. 
6.2.4 Criterion Replacement parts. Parts, components, special tools and test equipuent required for service, repair or replacement shall be comercially avallable or available from the system or subsystem manufacturer or supplier.

Evaluation Revlew of spectflcations : or the avallability of parts.

Commentary Th1s criterion is intended to preclude long periods of system downcime due to the need for the repair or replacement of parts.

A repair kit providing all commonly needed parts for repair will be provided with each collector. Instructions for use of the kit are included in the manual.

6.3 Requirement

Repalr and service personnel. The H, HC and DHW systems shall be designed in such a manner that they can be conventently repalred by qualifled service personnel.

6.3.1 Critertion Maintenance of $H$ and $H C$ systems. The $H$ and HC systems shall be capable of being serviced with a minlmum amount of special equipment by a tralned HVAC service technlcian using a maintenance manual.

Evaluation Review of drawtings, spectfications, and maintenance instructions.

Commentary The complexity and design of certain components may require their removal and replacement for repalr of the system.

See the collector manual and Criterion 6.1.1.

6.3.2 Criterion Maintenance of DHW sygtem. The DHW system shall be capable of being cerviced with a minimum amount of special equipment by a qualified service technictan using a maintenance manual.

Evaluation Review of drawings, spectfications, and maintenance lagtructions.

See the collector manual and Criterion 6.1.1.

8.3 Requitement Mechantcal and electrical functioning of connections. The connections between the $\mathrm{H}, \mathrm{HC}$, and DHW Byotams and the dwelling or alte shell function mechanlcelly or electrically as intended.

8.3.1 Criterion Plumblng connectiona Plumbing connectione between the eolar ouboyotell and weter service or waete dieposal ayoteme oball be In accordance w1th the IPS [3] or ANSI N19.1[4], as appl1cable.

Evaluacton Review of mechanteal drawings and any detallo or epec1ficatione related to plumbing connections.

Comentary Particular attention should be given to making oure that plumbing connections are dimenglonally coordinated, that plpe olzes and threads are compatible, and that changes in direction do not unduly restrict the flow of fluid.

The pipe connections at the inlet and outlet headers are standard $3 / 4^{\prime \prime}$ NPT. 
11.2.1 Criterion Chemlcal corrosion. Solar subsystems shall not cause chemical corrosion of the butlding or site elements to an extent that would significanlly impair theit intended performance.

Evaluation See Evaluition: Criteria 5.3.3 and 5.3.4 In Chapter Five, Systems: and Components.

See Criterion 5.3.3 and 5.3.4.

11.2.2 Criterion

Heat and moisture. Roof mounted solar subsystems shall not cause a bulldup of heat or molsture that would.cause excessive deterloration of the roofing system or other components of the dwelling.

Evaluation Review of architectural plans, specifications and calculations for temperature bulldup caused by solar subsystems.

Commentary. The presence of the collector can cause abnormal heat rises whlch could caise thermal degradation and the bulldup of molsture which could cause rotting.

The collector is designed to be mounted to the roof and $f l$ ashed to prevent moisture from building. up under the collector. The temperature of the roof structure is a function of the absorber temperature, the air temperature underneath the roof; the amount of insulation under the roof and the amount of insulation in the collector, which is fixed by the design of the collector at a $\mathrm{K}$ value of $.115 \mathrm{BTUH} / \mathrm{ft} 2{ }^{\circ} \mathrm{F}$. As suming the collector insulation is twice as effective as insulation in the roof, which is quite conservative given losses through joists and the fact that most attic insulation is on the attic floor and not under the roof, the roof structure temperature would be two-...... thirds between the absorber temperature and the air temperature underneath the roof. Assuming an extreme case of stagnation at $300^{\circ} \mathrm{F}$ and inside air temperature of $90^{\circ} \mathrm{F}$, the roof would be about $160^{\circ} \mathrm{F}$. The SUNMAT Collector has no design features to distinguish it in this respect from other collectors designed for direct mounting on the roof:

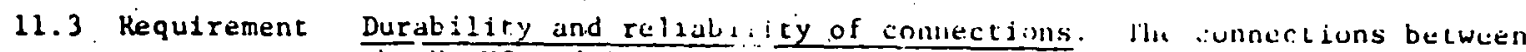
the H, HC and DHW syst ins and the dwelling that are exposed to external eavirulmental factors shall not undergu ihanges that will impair their functiulis.

11.3.1 Criterion Material compatibllity. Connector materials shall be chemically and physically compatible under in-use condicions.

Evaluation See Evaluation: Criterion 5.3.2 in Chapter Five, Systems and Components.

See Criterion 5.3.2. 
APPENDIX A

MATERIALS 


\section{A highly versatile group of Fiberglas insulating boards designed to insulate ductwork, equipment, vessels, and tanks, both thermally and acoustically. For operating temperatures to $+450 F$}

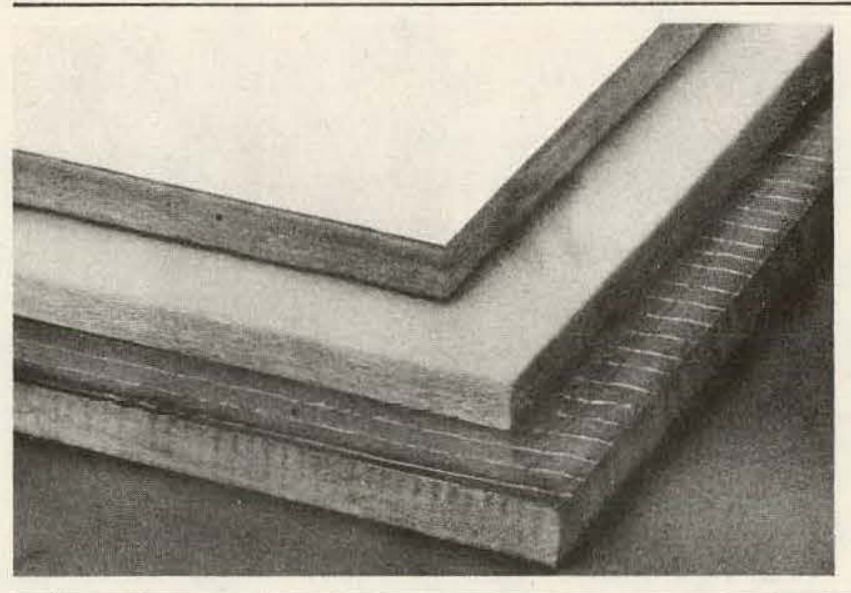

\section{uses}

The 700 series Boards have been designed primarily to insulate heating and air conditioning ducts, ovens, tanks, boilers, hot water generators and other hot equipment.

Type 701-A lightweight resilient insulation, in board form, used on vessels having irregular surfaces where the exterior finish is supported by welded studs, pins, or other mechanical attachments.

Type 703-A semi-rigid board recommended for use on equipment, vessels, and air conditioning ductwork.

Type 705-A rigid board with very high strength characteristics for use on chillers, hot and cold equipment, heating and air conditioning ductwork where greater abuse resistance and good appearance is required.

\section{description}

Fiberglas $* 700$ Series Industrial Insulations are made of inorganic glass fibers pre-formed into semi-rigid to rigid rectangular boards of varying densities. The series consists of Types 701, 703, and 705. Each type has specific thermal and physical characteristics which make it suitable for the uses described. Types 703 and 705 are available with factory-applied FRK-25. Type 705 is available with ASJ-25. Both facings are vapor barriers and provide a neat, finished appearance.

\section{benefits}

Lower operating costs-the exceptional thermal efficiency of Fiberglas 700 Series Insulations lowers operating costs.

End-use tailored-three densities offer a selection of products to meet specific performance and economic requirements.

Lower maintenance costs -700 Series Insulations resist damage, maintain structural integrity and efficiency. Thickness stays uniform.

Wide temperature-use range-applications range from $-60 \mathrm{~F}$ to $+450 \mathrm{~F}$.
Neat finished appearance-the boardlike characteristics of the heavier density Type 703 and 705 products provide neat square corners. The factory-applied facing provides an attractive finished appearance.

Immediate building code approval-Fiberglas 700 Series Insulation (faced and unfaced) has a UL flame spread rating of less than 25 .

Noise control-a versatile group of Fiberglas products that efficiently reduce sound transmission. 


\section{performance characteristics}

Sound absorption characteristics ( 2 " thick, \#6 mounting)

\begin{tabular}{c|ccc}
\hline $\begin{array}{c}\text { Frequency } \\
(\mathrm{Hz})\end{array}$ & \multicolumn{3}{|c}{ Insulation type (unfaced) } \\
\hline 125 & 701 & $\mathbf{7 0 3}$ & $\mathbf{7 0 5}$ \\
\hline 250 & .34 & .32 & .48 \\
500 & .70 & .74 & .82 \\
1000 & .96 & .97 & .97 \\
2000 & .97 & .98 & .99 \\
4000 & .86 & .87 & .90 \\
\hline NRC & .83 & .85 & .86 \\
\hline
\end{tabular}

\section{Size and Density}

\begin{tabular}{l|lll} 
& 701 & 703 & 705 \\
\hline Density (pcf) & 1.58 & 3.00 & 6.00 \\
\hline $\begin{array}{l}\text { Thickness (1/2" } \\
\text { (increments) }\end{array}$ & $11^{\prime \prime} 2^{\prime \prime}-4^{\prime \prime}$ & $1^{\prime \prime}-2^{\prime \prime}$ & $1^{\prime \prime}-2^{\prime \prime}$ \\
\hline $\begin{array}{l}\text { Compressive strength } \\
\text { (psf at 10\% deform.) }\end{array}$ & $4.5^{\prime \prime}$ & 100 & 350 \\
\hline $\begin{array}{l}\text { Standard size } \\
\text { (inches) }\end{array}$ & \multicolumn{3}{l}{$24^{\prime \prime} \times 48^{\prime \prime}$} \\
\hline $\begin{array}{l}\text { Thermal conductivity } \\
\text { at 75F mean temp. }\end{array}$ & 0.242 & 0.230 & 0.220 \\
\hline
\end{tabular}

*After compression packaged

\section{Thermal Conductivity}

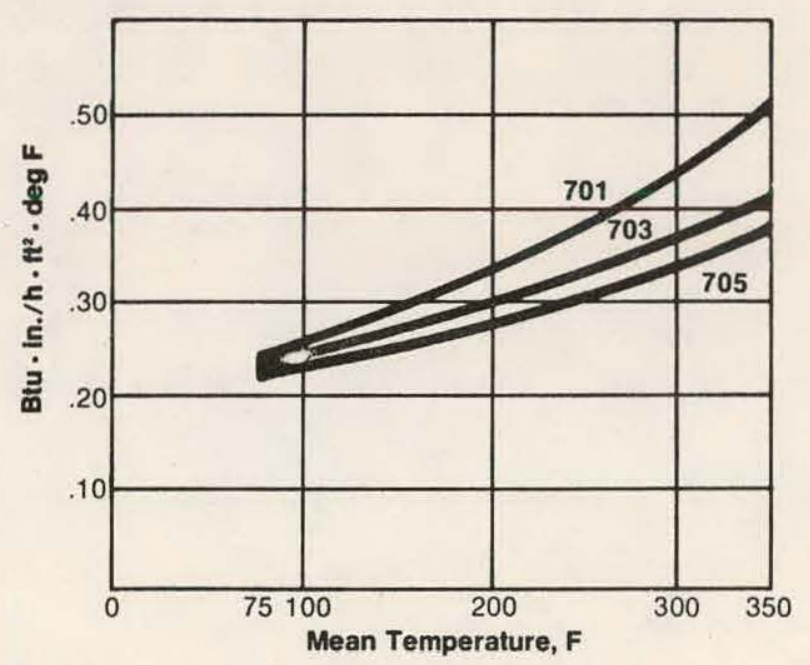

Molsture absorption-less than $2 \%$ by volume Bacteria and fungus resistance-does not breed or promote

Humidity and temperature effect-cycling conditions will not cause spalling or crumbling

Corrosion-does not accelerate corrosion of copper, steel, or aluminum

Fire safety-Fiberglas 700 Series, both faced and unfaced, can be specified and used without danger of contributing to the spread of fire or liberation of excessive smoke.

\section{facings}

Types 703 and 705 are available with the following factory-applied vapor barrier facings, with UL labels available if specified:

FRK-Foil reinforced kraft: 703, 705

ASJ-Embossed white kraft foil laminate: 705 only

Vapor transmission rates: ASJ-25-.02 perms FRK-25-.02 perms

Beach puncture resistance: ASJ-25-50 units FRK-25-25 units

\section{surface burning characteristics}

(unfaced or faced:)

flame spread

fuel contributed

25

smoke developed

50

(compared to untreated Red Oak as 100)

\section{application recommendations}

Type 701-lightweight unfaced flexible insulation in board form for use on vessels having irregular surfaces, where the compressive strength is not a performance criterion.

Types 703 and $705-$ board insulations normally impaled on welded pins on flat surfaces. They are cut in segments and banded in place on irregular surfaces. Unfaced boards are normally finished with reinforced insulating cement or weatherproof mastic. For outdoor application: Types 703 and 705 , faced.

ASJ-25 or FRK-25 faced insulation boards shall be applied using mechanical fasteners such as weld pins or stick clips. Fasteners shall be located not less than $3^{\prime \prime}$ from each edge or corner of the board. Pin spacing along the duct should be no greater than $12^{\prime \prime}$ on centers. Additional pins or clips may be required to hold the insulation tightly against the surface where cross breaking is used for stiffening. Weld pin lengths must be selected to insure tight fit but avoid "oil canning" effect.

Apply only OCF vapor seal ASJ or FRK pressuresensitive patches. Rub hard with the nylon sealing tool to insure a tight bond and a vapor seal.

All insulation edges and butt joints are to be sealed only with OCF pressure-sensitive joint sealing tape to match the jacket. Rub hard with nylon sealing tool. Use 3" wide tapes on flat surfaces, or where edges are shiplapped and stapled. 5 " wide tape can be used in lieu of shiplapping.

Precautlons:

- Keep all contact adhesive surfaces clean.

- Use nylon sealing tool to prevent wrinkles and fishmouths.

- Duct-work or radius may require pre-scoring to allow the board to conform to the surface.

- When painting the facings for indoor applications, use only water base/latex products.

Limitations:

- Pressure-sensitive sealing tapes or patches should only be applied when the ambient temperature is between $+35 \mathrm{~F}$ and $+110 \mathrm{~F}$.

- Maximum insulation surface temperatures in use are limited to $-10 \mathrm{~F}$ to $+150 \mathrm{~F}$.

- Outdoor applications require additional weather protection. 


\section{economic thickness}

Caution: The recommended Economic Thicknesses shown are chosen with respect to cost, thermal performance, and energy conservation. It is possible that heat may be generated from the resinous binder of insulations if ignited by external sources such as welding slag, cutting torches, etc. Care should be taken to avoid direct contact with the insulation by fire or ignition sources.

Selection of an insulation for any specific application should take into consideration the following important criteria: 1. Cost of insulation applied. 2. Cost of heat energy at midlife. 3. Cost of capital. 4. Capital investment in heat production equipment. 5. Temperature differential. 6. Size of the pipe surface. 7. Conductivity of insulation. 8. Depreciation period-insulation and facility. The thicknesses shown in the tables below are based on the following typical conditions:

\section{Commercial (full time):}

Annual fuel price increase: $4 \%$

Initial heat cost: $\$ 2.75 / 1000 \mathrm{lb}$. steam

Heat cost at midlife: $\$ 4.07 / 1000 \mathrm{lb}$. steam

Cost of money: $7 \frac{1}{2} \%$ /year

Capital investment: $\$ 20 / \mathrm{lb}$. steam / hour

Flat insulation cost $\left(1^{\prime \prime}\right)$ : $\$ 3.40 / \mathrm{sq} \mathrm{ft}$

Depreciation time: 20 years

Hours of operation: $8760 /$ year

Economic thickness for heated equipment to $450 \mathrm{~F}$ ( $80 \mathrm{~F}$ ambient, still air, commercial full time)

\begin{tabular}{|c|c|c|c|c|c|c|c|c|c|}
\hline \multirow{2}{*}{$\begin{array}{r}\text { Surface } \\
\text { Temp., F } \\
\end{array}$} & \multicolumn{3}{|c|}{ Type 701} & \multicolumn{3}{|c|}{ Type 703} & \multicolumn{3}{|c|}{ Type 705} \\
\hline & ET & HL & ST & ET & HL & ST & ET & HL & ST \\
\hline 150 & $2^{1 / 2}$ & 5 & 84 & $2^{1 / 2}$ & 5 & 84 & $2 \frac{1}{2}$ & 5 & 84 \\
\hline 200 & $3^{1 / 2}$ & 6 & 86 & $3 \frac{1}{2}$ & 6 & 86 & & * & \\
\hline 300 & $.51 \frac{1}{2}$ & 8 & 87 & & * & & & $*$ & \\
\hline 400 & 7 & 9 & 88 & & * & & & * & \\
\hline 450 & $7 \frac{1}{2}$ & 10 & 89 & & * & & & * & \\
\hline
\end{tabular}

ET = economic thickness, inches *For requirements in this area, contact $\mathrm{HL}=$ heat loss, Btu $/ \mathrm{hr} / \mathrm{sq} \mathrm{ft}$
$\mathrm{ST}$

\section{Commercial (part time):}

Annual fuel price increase: $4 \%$

Initial heat cost: $\$ 3.00 / 1000 \mathrm{lb}$. steam

Heat cost at midlife: $\$ 4.44 / 1000 \mathrm{lb}$. steam

Cost of money: $7 \frac{1}{2} \% /$ year

Capital investment: $\$ 20 / \mathrm{lb}$. steam/hour

Flat insulation cost $\left(1^{\prime \prime}\right): \$ 3.40 / \mathrm{sq} \mathrm{ft}$

Depreciation time: 20 years

Hours of operation: 5400 /year

Economic thickness for heated equipment to $450 \mathrm{~F}$ ( $80 \mathrm{~F}$ ambient, still air, commercial part time)

\begin{tabular}{c|crr|rrr|rrr}
\hline Surface & \multicolumn{3}{|c|}{ Type 701 } & \multicolumn{3}{c|}{ Type 703 } & \multicolumn{3}{c}{ Type 705 } \\
Temp. & ET & HL & ST & ET & HL & ST & ET & HL & ST \\
\hline 150 & 2 & 6 & 86 & 2 & 6 & 85 & 2 & 6 & 85 \\
200 & 3 & 7 & 87 & 3 & 7 & 86 & 3 & 7 & 86 \\
300 & $41 / 2$ & 9 & 88 & 4 & 10 & 89 & & $*$ & \\
400 & $51 / 2$ & 11 & 90 & & $*$ & & & $*$ & \\
450 & 6 & 12 & 91 & & $*$ & & & $*$ \\
\hline
\end{tabular}

ET $=$ economic thickness, inches *For requirements in this area, contact $\mathrm{HL}=$ heat loss, Btu/hr/sq ft $\mathrm{ST}=$ surface temperature, deg $\mathrm{F}$
Thickness to prevent condensation on cold ducts and equipment-faced board

The following chart indicates the recommended thickness for installation on cold air ducts at various temperature differences (duct to air). Also shown are values for heat gain and approximate maximum relative humidity allowable.

\begin{tabular}{cccc}
\hline $\begin{array}{c}\text { Temperature } \\
\text { Differences } \\
\text { deg. F }\end{array}$ & $\begin{array}{c}\text { Recommended } \\
\text { Thickness } \\
\text { (inches) }\end{array}$ & $\begin{array}{c}\text { Heat Gain } \\
\text { Btu/sq ft/hr }\end{array}$ & $\begin{array}{c}\text { Permissible } \\
\text { Relative } \\
\text { Humidity }\end{array}$ \\
\hline 20 & 1 & 4.3 & $90 \%$ \\
25 & 1 & 5.2 & $87 \%$ \\
30 & 1 & 6.1 & $89 \%$ \\
35 & 1 & 7.1 & $88 \%$ \\
40 & $1 \frac{1}{2}$ & 5.7 & $90 \%$ \\
45 & $11 / 2$ & 6.3 & $89 \%$ \\
50 & 2 & 5.4 & $90 \%$ \\
\hline
\end{tabular}

\section{specification compliance}

\begin{tabular}{|c|c|c|c|}
\hline & 701 & $703^{*}$ & 705 \\
\hline $\mathrm{HH}-\mathrm{I}-558 \mathrm{~B}$, Form A, Class 1 & • & • & • \\
\hline $\mathrm{HH}-\mathrm{I}-558 \mathrm{~B}$, Form A, Class 2 & & $\bullet$ & • \\
\hline HH-I-558B, Form B, Type 1, Class 7 & • & & \\
\hline Navy Bureau of Yards \& Docks TS- 15180 & & - & - \\
\hline Corps of Engineers C.E. $-301.08, .11, .12$ & & - & - \\
\hline NFPA $90 A$ & & - & - \\
\hline
\end{tabular}

-Type $703 \mathrm{G}$ is specially produced for contracts where certification of compliance to the above Federal Specification is required. Available plain or faced for use on hot or cold equipment and for air conditioning ductwork. 


\section{Offices of Owens-Corning Fiberglas Corporation}

\begin{tabular}{|c|c|c|c|}
\hline ALABAMA & & INDIANA & \\
\hline Birmingham & $205-786-3461$ & Elkhart & $219-294-3627$ \\
\hline Mobile & $205-471-5465$ & Evansville & $812-425-5124$ \\
\hline ALASKA & & $\begin{array}{l}\text { Fort Wayne } \\
\text { Indianapolis }\end{array}$ & $\begin{array}{l}219-483-9552 \\
317-898-1140\end{array}$ \\
\hline Anchorage & $907-272-6425$ & & \\
\hline $\begin{array}{l}\text { ARIZONA } \\
\text { Phoenix }\end{array}$ & $602-277-6217$ & Des Moines & $515-223-1205$ \\
\hline ARKANSAS & & KANSAS & \\
\hline Little Rock & $501-664-2133$ & $\begin{array}{l}\text { Kansas City } \\
\text { Wichita }\end{array}$ & $\begin{array}{l}913-281-4322 \\
316-265-2522\end{array}$ \\
\hline $\begin{array}{l}\text { CALIFORNIA } \\
\text { Fresno }\end{array}$ & & KENTUCKY & \\
\hline $\begin{array}{l}\text { Fresno } \\
\text { Los Angeles }\end{array}$ & $\begin{array}{l}209-266-4193 \\
213-724-5383\end{array}$ & Louisville & $502-456-4230$ \\
\hline Sacramento & $916-927-1896$ & LOUISIANA & \\
\hline San Bernardino & $714-885-3496$ & New Orleans & $504-837-2902$ \\
\hline San Diego & $\begin{array}{l}714-234-0933 \\
415-873-7950\end{array}$ & Shreveport & $318-222-7100$ \\
\hline Santa Clara & $408-296-2525$ & $\begin{array}{c}\text { MARYLAND } \\
\text { Baltimore }\end{array}$ & $301-730-9300$ \\
\hline $\begin{array}{l}\text { COLORADO } \\
\text { Denver }\end{array}$ & $303-757-6121$ & $\begin{array}{l}\text { MASSACHUSETTS } \\
\text { Boston }\end{array}$ & $617-235-7540$ \\
\hline $\begin{array}{l}\text { CONNECTICUT } \\
\text { East Hartford } \\
\text { Hartford }\end{array}$ & $\begin{array}{l}203-289-6411 \\
203-524-5987\end{array}$ & $\begin{array}{l}\text { MICHIGAN } \\
\text { Detroit } \\
\text { Flint }\end{array}$ & $\begin{array}{l}313-547-8000 \\
313-787-6573\end{array}$ \\
\hline $\begin{array}{c}\text { DISTRICT OF CO } \\
\text { Wash. (Gov't.) }\end{array}$ & $\begin{array}{l}\text { UMBIA } \\
202-296-3296\end{array}$ & $\begin{array}{l}\text { Grand Rapids } \\
\text { Lansing }\end{array}$ & $\begin{array}{l}616-452-8788 \\
517-372-4930\end{array}$ \\
\hline Wash. (Sales) & $301-730-9300$ & MINNESOTA & \\
\hline $\begin{array}{l}\text { FLORIDA } \\
\text { Jacksonville }\end{array}$ & & Minneapolis & $612-884-5375$ \\
\hline Miami & $\begin{array}{l}904-786-5880 \\
305-651-2113\end{array}$ & St. Paul & $612-$ \\
\hline $\begin{array}{l}\text { Orlando } \\
\text { Tampa }\end{array}$ & $\begin{array}{l}305-843-2432 \\
813-877-7516\end{array}$ & $\begin{array}{l}\text { MISSISSIPPI } \\
\text { Jackson }\end{array}$ & $601-982-0810$ \\
\hline $\begin{array}{l}\text { GEORGIA } \\
\text { Albany }\end{array}$ & & $\begin{array}{l}\text { MISSOURI } \\
\text { Kansas City }\end{array}$ & $816-753-7725$ \\
\hline $\begin{array}{l}\text { Albany } \\
\text { Atlanta }\end{array}$ & $\begin{array}{l}912-883-6317 \\
404-352-3566\end{array}$ & St. Louis & $314-991-2640$ \\
\hline $\begin{array}{l}\text { HAWAII } \\
\text { Honolulu }\end{array}$ & $808-537-3832$ & $\begin{array}{l}\text { MONTANA } \\
\text { Billings }\end{array}$ & $406-252-8496$ \\
\hline $\begin{array}{c}\text { IDAHO } \\
\text { Boise }\end{array}$ & $208-342-9311$ & $\begin{array}{l}\text { NEBRASKA } \\
\text { Omaha }\end{array}$ & $402-397-2072$ \\
\hline $\begin{array}{l}\text { ILLINOIS } \\
\text { Chicago } \\
\text { Rock Island }\end{array}$ & $\begin{array}{l}312-583-0100 \\
309-788-6309\end{array}$ & $\begin{array}{l}\text { NEW JERSEY } \\
\text { Berlin } \\
\text { Cherry Hill } \\
\text { Newark }\end{array}$ & $\begin{array}{l}609-767-3300 \\
609-428-8590 \\
201-484-8800\end{array}$ \\
\hline
\end{tabular}

\begin{tabular}{|c|c|}
\hline $\begin{array}{l}\text { NEW MEXICO } \\
\text { Albuquerque }\end{array}$ & $505-294-5511$ \\
\hline $\begin{array}{l}\text { NEW YORK } \\
\text { Albany } \\
\text { Buffalo } \\
\text { Delmar } \\
\text { New York } \\
\text { Rochester } \\
\text { Scarsdale } \\
\text { Syracuse }\end{array}$ & $\begin{array}{l}518-869-0221 \\
716-832-1410 \\
518-439-7651 \\
212-759-3810 \\
716-381-0340 \\
914-472-3400 \\
315-455-1071\end{array}$ \\
\hline $\begin{array}{l}\text { NORTH CAROLIN } \\
\text { Chariotte } \\
\text { Greensboro } \\
\text { Raleigh }\end{array}$ & $\begin{array}{l}704-372-7065 \\
919-273-0528 \\
919-872-0823\end{array}$ \\
\hline $\begin{array}{l}\text { OHIO } \\
\text { Akron } \\
\text { Cincinnati } \\
\text { Cleveland } \\
\text { Columbus } \\
\text { Toledo }\end{array}$ & $\begin{array}{l}216-867-5770 \\
513-563-4270 \\
216-884-9440 \\
614-451-6420 \\
419-259-3031\end{array}$ \\
\hline $\begin{array}{l}\text { OKLAHOMA } \\
\text { Oklahoma City } \\
\text { Tulsa }\end{array}$ & $\begin{array}{l}405-848-6761 \\
918-627-1220\end{array}$ \\
\hline $\begin{array}{l}\text { OREGON } \\
\text { Portland }\end{array}$ & $503-620-1014$ \\
\hline $\begin{array}{l}\text { PENNSYLVANIA } \\
\text { Berwyn } \\
\text { Bethlehem } \\
\text { Harrisburg } \\
\text { Philadelphia } \\
\text { Pittsburgh }\end{array}$ & $\begin{array}{l}215-647-2700 \\
215-865-0427 \\
717-761-0430 \\
215-647-3405 \\
412-563-7766\end{array}$ \\
\hline $\begin{array}{l}\text { RHODE ISLAND } \\
\text { Cumberland } \\
\text { Providence }\end{array}$ & $\begin{array}{l}401-333-6071 \\
401-434-7437\end{array}$ \\
\hline $\begin{array}{l}\text { SOUTH CAROLIN } \\
\text { Columbia } \\
\text { Greenville }\end{array}$ & $\begin{array}{l}803-252-9983 \\
803-271-9331\end{array}$ \\
\hline $\begin{array}{l}\text { TENNESSEE } \\
\text { Knoxville } \\
\text { Memphis } \\
\text { Nashville }\end{array}$ & $\begin{array}{l}615-584-6161 \\
901-362-2010 \\
615-297-9592\end{array}$ \\
\hline
\end{tabular}

TEXAS

Houston

$713-869-9363$

San Antonio $\quad 512-828-0658$

UTAH

Salt Lake City $\quad 801-487-6204$

VIRGINIA

Norfolk

Richmond

804-461-8114

$804-272-5851$

WASHINGTON

Seattle

Spokane

WEST VIRGINIA

Charleston

WISCONSIN

Milwaukee

206-762-4250

509-924-6532

304-744-2291

414-259-0700

INTERNATIONAL GENERAL

OFFICE:

Toledo, Ohio $\quad 419-259-3492$

EXPORT SALES OFFICES

Caparra Hgts., P.R. 809-781-5165

Miami, Florida 305-377-0974

New York, N.Y. $\quad 212-759-3810$

Toledo, Ohio $\quad 419-259-3023$

EUROPEAN HEAD OFFICE:

Brussels, Belgium 02/672.23.26

EUROPEAN SALES OFFICES:

Ascot, Berkshire, Eng. 990/24888 Brussels, Belgium

(Benelux Sales) 02/672.23.26

Milan, Italy

Survilliers, France $\quad 1 / 471-9210$

Wiesbaden, Ger. 06121/562031

SOUTH AMERICAN OFFICES:

Bogota, Colombia 348020

Porto Alegre, Brazil 22/7505

Rio de Janeiro, Brazil 222-0768

Sao Paulo, Brazil $\quad 257-8966$

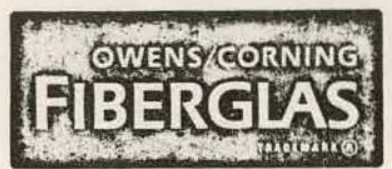

OWENS-CORNING FIBERGLAS CORPORATION

Mechanical Products Division

Fiberglas Tower, Toledo, Ohio 43659 

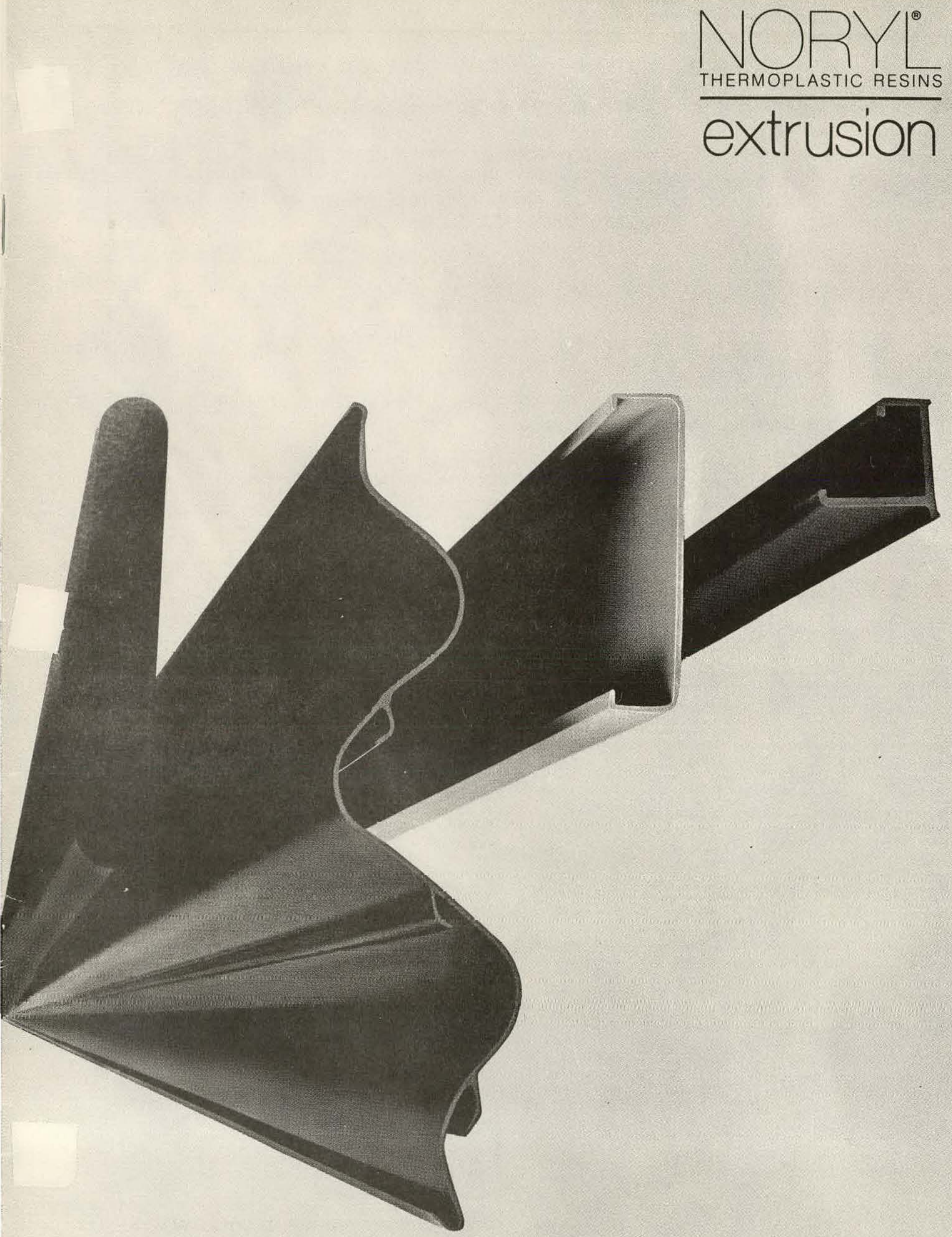


\section{Contents}

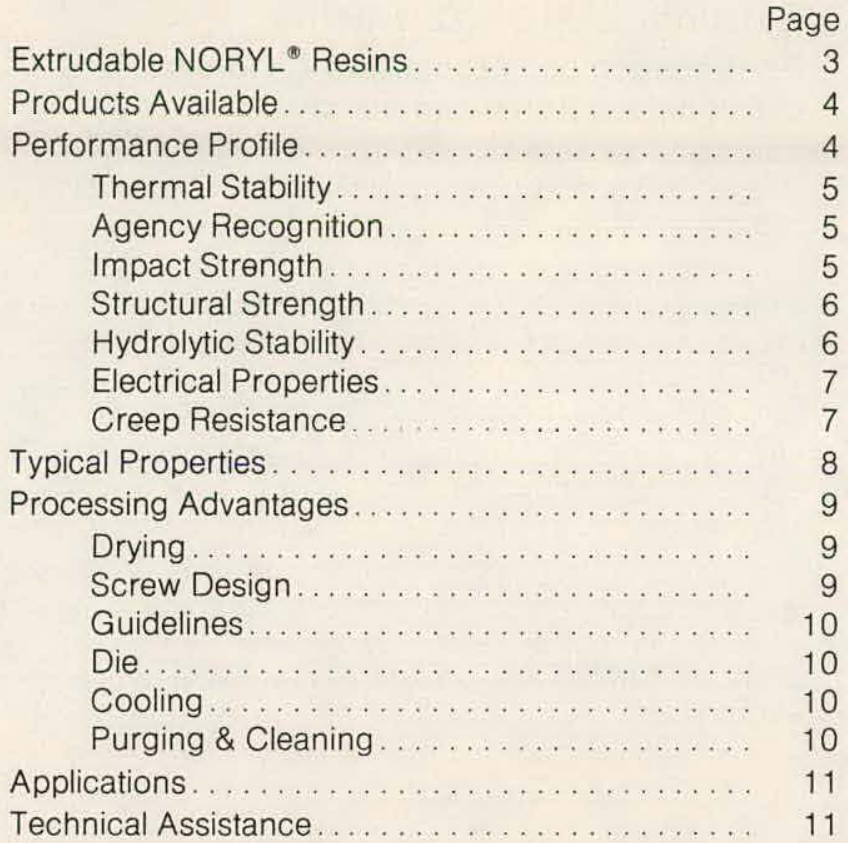




\section{Introduction \\ Extrudable NORYL Resins \\ Performance and processability no other extrudable material can match.}

With their combined properties and processability, extrudable NORYL resins offer advantages to both the designer and the fabricator.

On performance, NORYL resins feature heat resistance under load from $212^{\circ}-265^{\circ} \mathrm{F}$. Combined with this are impact strength of $5.0 \mathrm{ft}-\mathrm{lbs}$. notched Izod, dimensional stability, broad U.L. recognition, excellent electrical properties and extremely low moisture absorption.

From an extrusion standpoint, this family of materials delivers excellent processability, melt strength and stability and high thru-put rates.

Extrudable NORYL resins' combination of performance and processability makes them ideal for a wide range of applications. It also opens new opportunities for the economics of plastics extrusion where metal was once required. 


\section{Products Available}

Extrudable NORYL resins are available in three high performance grades to meet a wide range of engineering requirements efficiently and reliably.

\section{NORYL EN-212}

Heat resistance of $212^{\circ} \mathrm{F}$ at 264 psi, a U.L. $94 \mathrm{~V}-1$ rating and excellent mechanical and electrical properties are all combined in NORYL EN-212. This all-around performance represents a significant step up over FR ABS and PVC, and allows thinner-walled designs for material savings.

\section{NORYL EN-265}

For applications requiring higher heat resistance plus broad U.L. recognition and impact strength, choose NORYL EN-265.

Its heat resistance of $265^{\circ} \mathrm{F}$ under load is coupled with high impact strength, excellent electrical properties and a U.L. $94 \mathrm{~V}-1$ rating. Combined, these properties make it the ideal metal replacement material for extrusions requiring durability, stability and U.L. approval.

\section{NORYL ENG-265}

High performance NORYL ENG-265 offers a property profile quite similar to EN-265, without the U.L. $94 \mathrm{~V}-1$ rating. This general purpose grade is an excellent material for applications requiring high mechanical strength and heat resistance under load.

\section{Performance Profile}

Extrudable NORYL resins answer the need for materials that offer a significant step up in performance over FR ABS and PVC. And with their higher thermal and mechanical properties, extrudable NORYL resins allow the designer to replace more costly metal extrusions for economy without sacrificing performance.

The combined properties of extrudable NORYL resins also mean you can design for thinner walls than are possible with PVC or FR ABS, for a significant savings in material. In fact, one application formerly in commodity plastics has been redesigned in NORYL resins with a $30 \%$ thinner wall. And the parts actually outperformed their predecessors with higher mechanical and thermal properties.

Compare the performance of extrudable NORYL resins to traditional commodity materials. While others may offer one key property, NORYL resins combine all the properties you need for all-around performance and reliability. 


\section{Properties}

\section{Thermal Stability}

With extrudable NORYL resins, you can choose from a range of heat distortion temperatures from $212^{\circ} \mathrm{F}$ to $265^{\circ} \mathrm{F}$ at $264 \mathrm{psi}$. And this heat resistance shows little decrease with increasingly applied stress.

Low thermal conductivity and coefficients of linear thermal expansion add to the heat-related advantages of extrudable NORYL resins.

\section{Agency Recognition}

All three extrudable NORYL resins carry broad U.L. recognition. U.L. continuous-use ratings range from $80^{\circ} \mathrm{C}$ to $110^{\circ} \mathrm{C}$, and two grades meet U.L. $94 \mathrm{~V}-1$ requirements. NORYL resins also carry a strong record of approval for sole-support of current carrying parts, a critical factor in many electrical applications.

\section{Impact Strength}

Unlike CPVC and FR ABS, extrudable NORYL resins combine heat resistance with high impact strength (Fig. 1). And they retain more of their toughness down to $-40^{\circ} \mathrm{F}$ to insure durability at temperature extremes.

\section{Figure 1: Impact Strength}

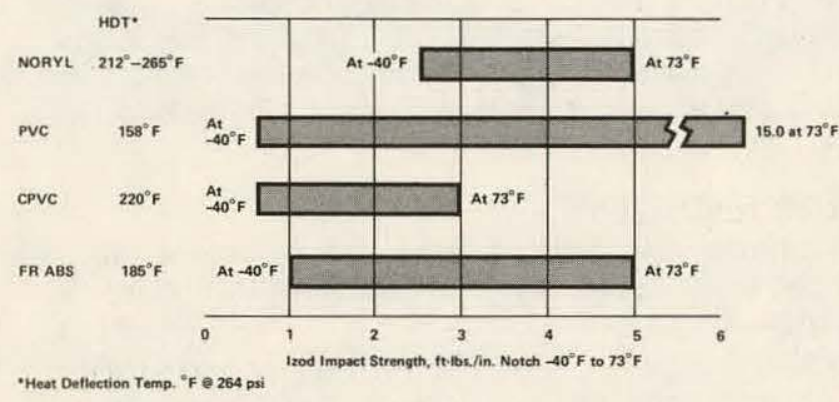

NORYL resin's ability to withstand a $20 \mathrm{KV}$ voltage test, its resistance to an industrial alkaline environment, low creep and U.L. recognition prompted the manufacturer of this bus bar sleeve to use NORYL EN-265. The material also cut the cost of the unit significantly over its fiberglass predecessor.

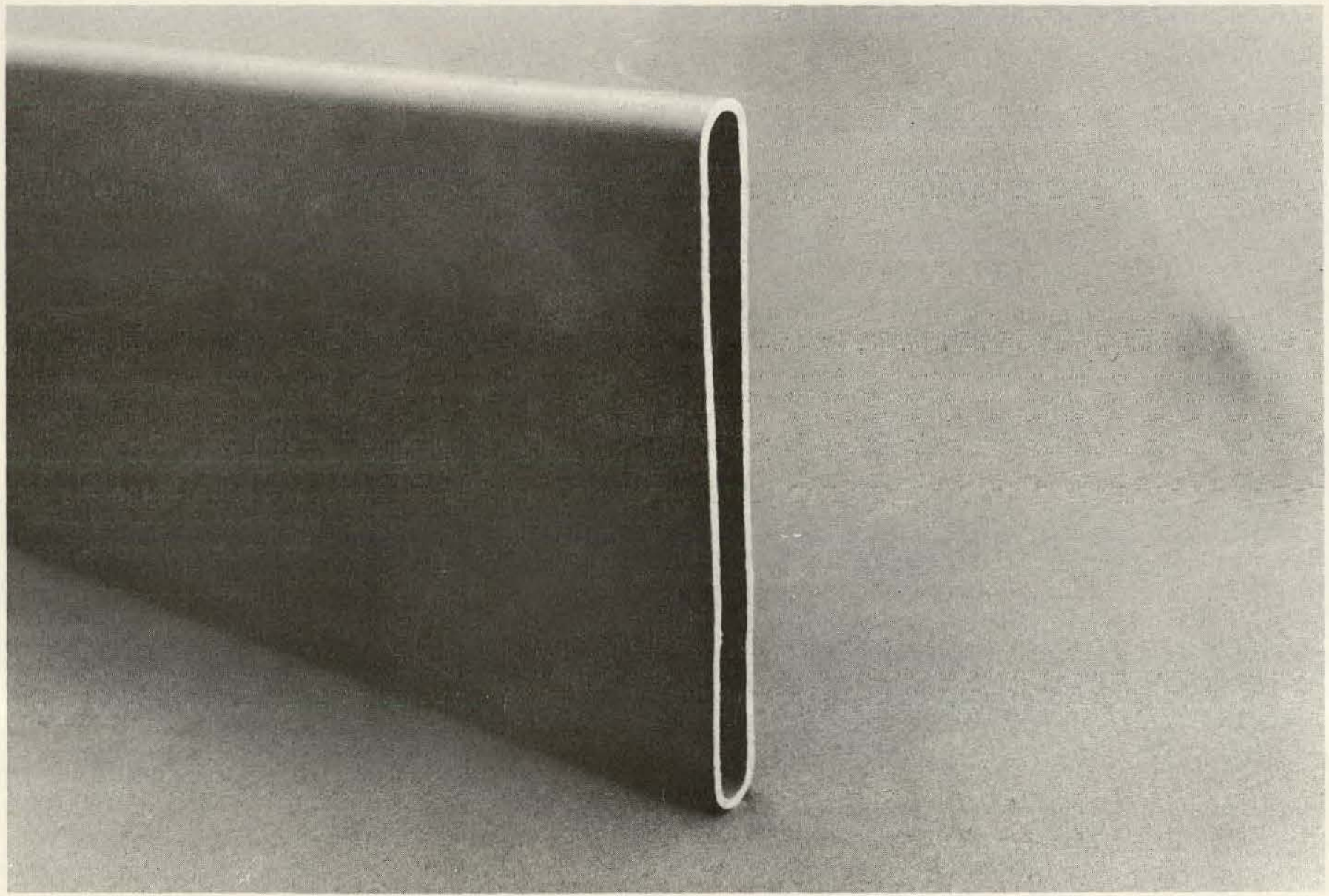




\section{Structural Strength}

Where structural strength counts, extrudable NORYL resins deliver better than FR ABS or PVC (Fig. 2).

Tensile strengths range from 7,800 to 9,600 psi. Flexural modulus ranges from 360,000 to $380,000 \mathrm{psi}$, and is only slightly affected by elevated temperatures.

With this mechanical strength, extrudable NORYL resins are the ideal choice for structural or load bearing applications. They're also ideally suited for functional designs such as snap-fits for mating two extruded parts.

\section{Figure 2: Tensile Strength}

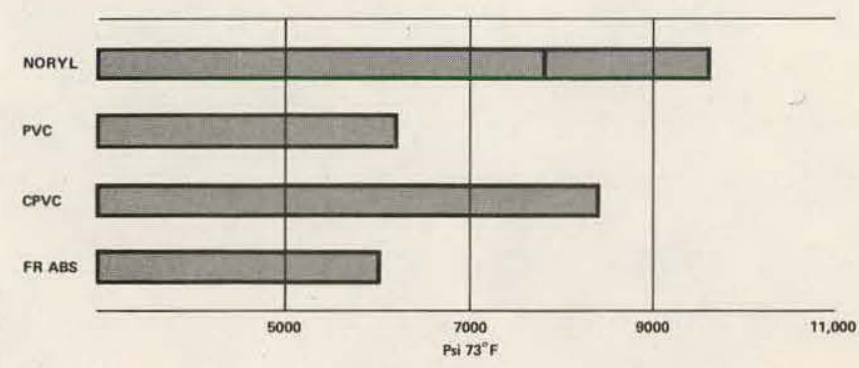

\section{Hydrolytic Stability}

All NORYL resins feature an extremely low water absorption rate at $0.066 \%$ (Fig. 3 ).

What's more, even long term exposure to hot water or steam has minimal effect on their mechanical properties. This characteristic helps insure dimensional stability and long term performance for any application exposed to moisture.

Extrudable NORYL resins are also completely resistant to hydrolysis, and can withstand virtually all acids and bases.

Figure 3: Water Absorption

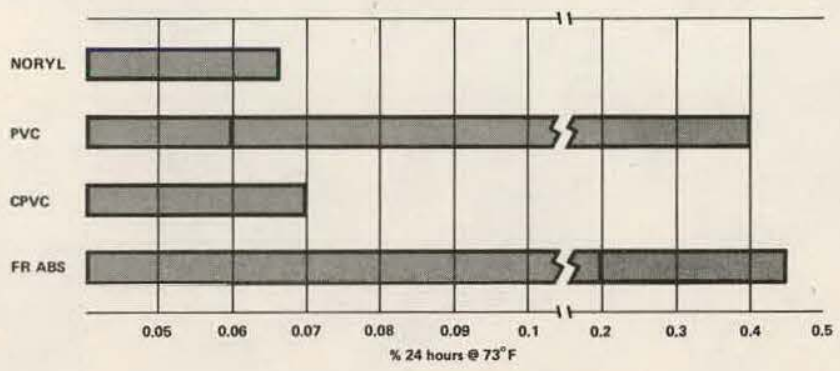

With its excellent hydrolytic stability, low creep, resistance to acid and alkaline solutions, and its processability, NORYL ENG-265 was the choice over PVC for this scrubber vane and mist eliminator used in processing plants and environmental equipment.

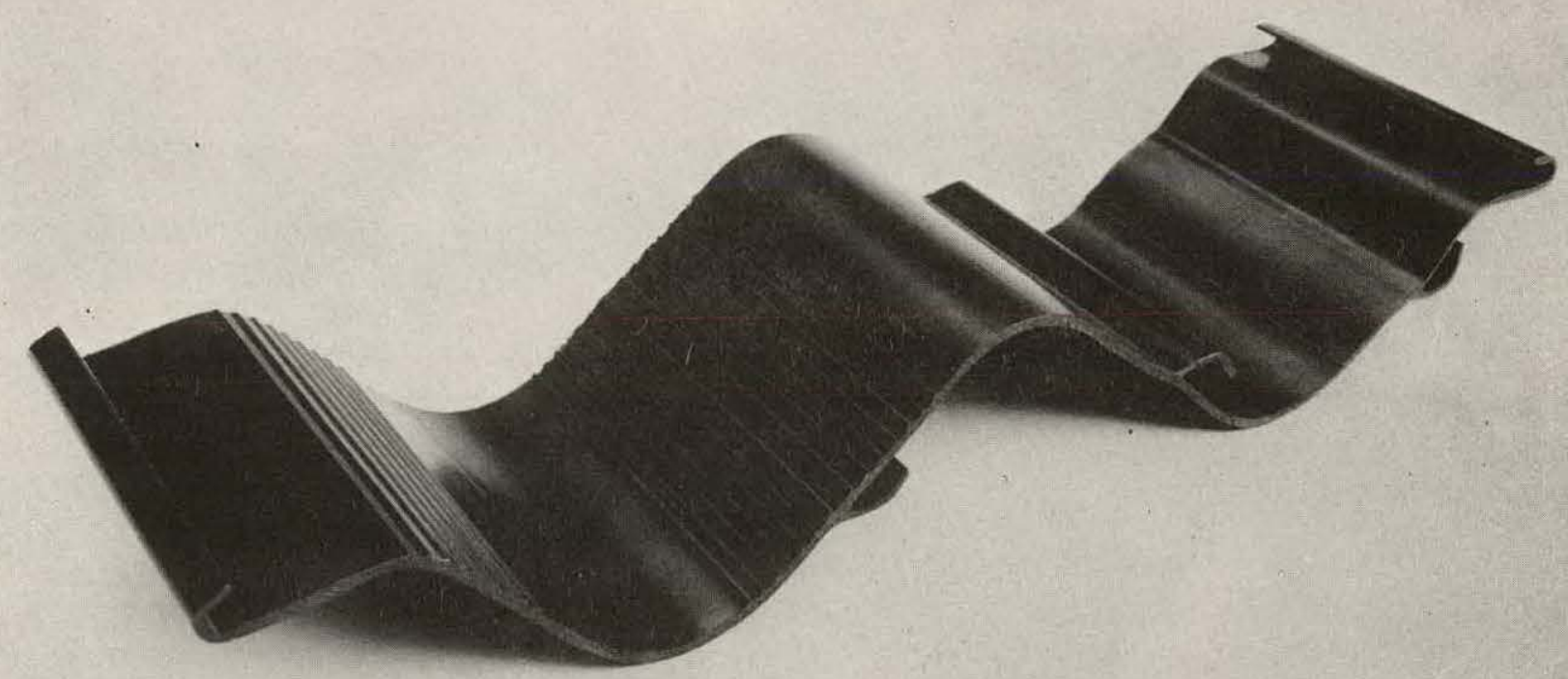




\section{Electrical Properties}

High volume resistivity and dielectric strength make extrudable NORYL resins ideal for a variety of electrical applications. Their low dielectric constants and dissipation factors are virtually unaffected by frequencies from 60 to $10^{6} \mathrm{cps}$, changes in humidity and by high temperatures.

\section{Creep Resistance}

With excellent creep resistance at elevated temperatures extrudable NORYL resins offer high stability and predictable long term performance under load. Their ability to resist deformation under prolonged stress also makes them ideal for metal replacement.

In this interlocking wiring splice cover, NORYL resin offered the high impact strength needed to withstand handling and installation abuse, even in sub-zero tem peratures. NORYL resin also had the processability to allow fast, efficient production of this complex shape.

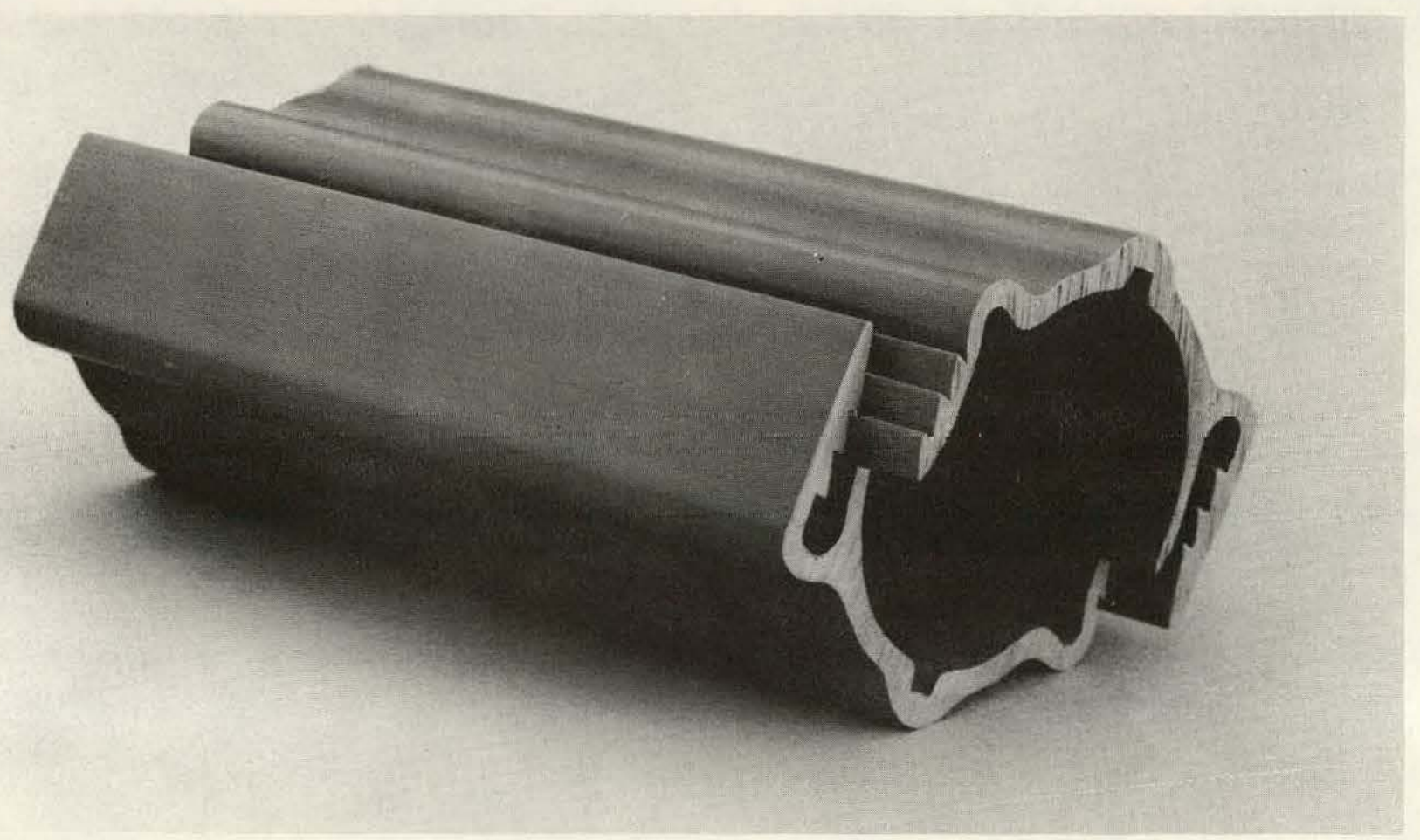




\section{Typical Properties-Extrudable NORYL Resins}

\begin{tabular}{|c|c|c|c|c|}
\hline & ASTM & $\begin{array}{l}\text { NORYL } \\
\text { ENG }-265\end{array}$ & $\begin{array}{l}\text { NORYL } \\
\text { EN-265 }\end{array}$ & $\begin{array}{l}\text { NORYL } \\
\text { EN-212 }\end{array}$ \\
\hline \multicolumn{5}{|l|}{ PHYSICAL } \\
\hline Specific Gravity, $73^{\circ} \mathrm{F}$ & D792 & 1.06 & 1.06 & 1.10 \\
\hline Water Absorption & D570 & 0.066 & 0.066 & 0.07 \\
\hline Tensile Strength, psi at $73^{\circ} \mathrm{F}$ & D638 & 9,600 & 9,600 & 7,800 \\
\hline Elongation at Break, \% . & D638 & 60 & 60 & 50 \\
\hline Tensile modulus, psi at $73^{\circ} \mathrm{F}$ & D638 & 355,000 & 355,000 & 380,000 \\
\hline Flexural Strength, psi at $73^{\circ} \mathrm{F}$ & D790 & 13,500 & 13,500 & 12,800 \\
\hline Flexural Modulus, psi at $73^{\circ} \mathrm{F}$ & D790 & 360,000 & 360,000 & 360,000 \\
\hline Compressive Strength ( $10 \%$ deformation) psi & D695 & 16,400 & 16,400 & 16,000 \\
\hline Shear Strength, psi & D732 & 10,500 & 10,500 & 6,900 \\
\hline Deformation Under Load, $\%$ at $2,000 \mathrm{psi}, 122^{\circ} \mathrm{F}$ & D621 & 0.30 & 0.30 & 0.50 \\
\hline Creep ( $300 \mathrm{hrs} 73^{\circ} \mathrm{F}$ at $2,000 \mathrm{psi}$ ) \% Strain (e) & D674 & 0.63 & 0.63 & 0.80 \\
\hline \multirow{2}{*}{$\begin{array}{r}\text { Izod Impact Strength, } \mathrm{ft} \text { Ibs. in. Notch@ } 73^{\circ} \mathrm{F} \\
\text { @ }-40^{\circ} \mathrm{F}\end{array}$} & D256 & 5.0 & 5.0 & 5.0 \\
\hline & & 2.5 & 2.5 & 2.5 \\
\hline Rockwell Hardness & D785 & R119 & R119 & R115 \\
\hline \multicolumn{5}{|l|}{ THERMAL } \\
\hline Heat Deflection Temperature (264 psi), ${ }^{\circ} \mathrm{F}$ & D648 & 265 & 265 & 212 \\
\hline Thermal Conductivity, Btu $/ \mathrm{hr} / \mathrm{ft}^{2} /{ }^{\circ} \mathrm{F} / \mathrm{in}$ & c177 & 1.5 & 1.5 & 1.1 \\
\hline $\begin{array}{l}\text { Coefficient of Thermal Expansion, in } / \text { in } /{ }^{\circ} \mathrm{F} \\
\left(-20^{\circ} \text { to } 150^{\circ} \mathrm{F}\right)\end{array}$ & D696 & $3.3 \times 10^{-5}$ & $3.3 \times 10^{-5}$ & $3.8 \times 10^{-5}$ \\
\hline \multicolumn{5}{|l|}{ ELECTRICAL } \\
\hline Dielectric Constant ( $50 \% \mathrm{RH}, 73^{\circ} \mathrm{F}$ at $60 \mathrm{cps}$ ) & D150 & 2.64 & 2.69 & 2.65 \\
\hline Dissipation Factor ( $50 \% \mathrm{RH}, 73^{\circ} \mathrm{F}$ at $60 \mathrm{cps}$ ) & D150 & 0.0004 & 0.0007 & 0.0007 \\
\hline Volume Resistivity, dry, ohm, cm.. $73^{\circ} \mathrm{F}$ & D257 & 1017 & 1017 & $10^{16}$ \\
\hline Surface Resistivity, ohm/sq & D257 & 1017 & 1017 & 1016 \\
\hline Dielectric Strength ( $1 / 8^{\prime \prime}$ sample), volts/mil & D149 & 550 & 500 & 400 \\
\hline Arc Resistance (Tungsten), sec. & D495 & 75 & 75 & 70 \\
\hline \multicolumn{5}{|l|}{ U. L. } \\
\hline U. L. Subject 94 & -- & $\mathrm{HB}$ & $94 \mathrm{~V}-1$ & $94 \mathrm{~V}-1$ \\
\hline \multicolumn{5}{|l|}{ U. L. Continuous Use, ${ }^{\circ} \mathrm{C}$} \\
\hline $\begin{array}{l}\text { With Impact } \\
\text { Electrical Without Impact }\end{array}$ & $\overline{--}$ & $\begin{array}{r}90^{\circ} \mathrm{C} \\
105^{\circ} \mathrm{C}\end{array}$ & $105^{\circ} \mathrm{C}$ & $\begin{array}{l}80^{\circ} \mathrm{C} \\
95^{\circ} \mathrm{C}\end{array}$ \\
\hline
\end{tabular}




\section{Processing Advantages}

One of the key advantages of extrudable NORYL resins over FR ABS and PVC lies in processing

NORYL resins have shown up to $30 \%$ faster production rates over PVC in actual applications. This is a product of NORYL resins significantly higher thru-put rate. Drawdown ratios up to $50 \%$ have virtually no effect on properties, unlike materials which are more subject to orientation. Another asset is processing stability. Noryl resins offer a broader range of processing conditions to minimize the problem of degradation during the extrusion process. They also feature excellent melt strength for better sizing ability.

NORYL resins also exhibit excellent regrind stability with little loss of properties after several recycles (Fig. 4) The combination of this processability, plus the performance which often allows thinner wall designs over PVC and ABS makes NORYL resins an economical, higher performance extrusion material.

Extrudable NORYL resins can be processed over a wide range of conditions. Optimum settings should be developed at the extruder according to available equipment, sizing equipment and cooling system

\section{Drying}

While moisture has virtually no effect on the properties of NORYL resins, drying is recommended to remove surface appearance defects which moisture may cause in processing.

Figure 4: Physical Properties of NORYL EN-265 after Repeated $100 \%$ Regrinding

\begin{tabular}{|c|c|c|c|}
\hline \multirow[b]{2}{*}{ Property } & \multirow{2}{*}{$\begin{array}{l}\text { Virgin } \\
\text { NORYL } \\
\text { EN-265 }\end{array}$} & \multicolumn{2}{|c|}{$100 \%$ Regrind } \\
\hline & & 1st Cycle & 3rd Cycle \\
\hline Tensile Strength, psi & 9,500 & 9,600 & 9,750 \\
\hline Flexural Modulus, psi & 360,000 & 360,000 & 365,000 \\
\hline Elongation. \% & 55 & 50 & 50 \\
\hline Notched Izod Impact & 5.0 & 4.7 & 4.5 \\
\hline
\end{tabular}

Although vented extruders are preferred, non-vented extruders have been used successfully with NORYL resins pre-dried in shallow trays, 1 "to $1-1 / 2$ " deep in an air circulating oven, at the following temperatures:

\begin{tabular}{clll}
\multicolumn{3}{l}{ Recommended Drying Times/Temperatures } \\
\hline NORYL & NORYL & NORYL \\
EN-265 & ENG-265 & EN-212 \\
\hline Drying Temp. $220-240^{\circ} \mathrm{F}$ & $220-240^{\circ} \mathrm{F}$ & $200-220^{\circ} \mathrm{F}$ \\
Drying Time & $2-4$ hours & $2-4$ hours & $2-4$ hours \\
& maximum & maximum & maximum \\
\hline
\end{tabular}

\section{Screw Design}

Both single and two-stage screw designs can be used successfully with extrudable NORYL resins (Fig. 5). $L / D$ ratio of 24 to 1 or greater is recommended. Compression ratio of 2.85 to 3.65 has been used very successfully. A long and shallow metering section is recommended for good melt preparation.

A typical two-stage screw is described belcw on a $2-1 / 2$ ", 24/1 L/D ratio extrusion machine:

\begin{tabular}{lcc}
\hline Section & No. Diameters & Depth, Inches \\
\hline Feed & 5 & 0.370 \\
Transition 1 & 3.5 & -- \\
Meter 1 & 6 & 0.110 \\
Vent & 3.5 & 0.350 \\
Transition 2 & 2 & -- \\
Meter 2 & 4 & 0.190 \\
\hline
\end{tabular}

Both CPVC and NORYL EN-265 were considered for this lighting track. NORYL resins came through with better heat resistance, U L. approval and a faster produc tion rate.

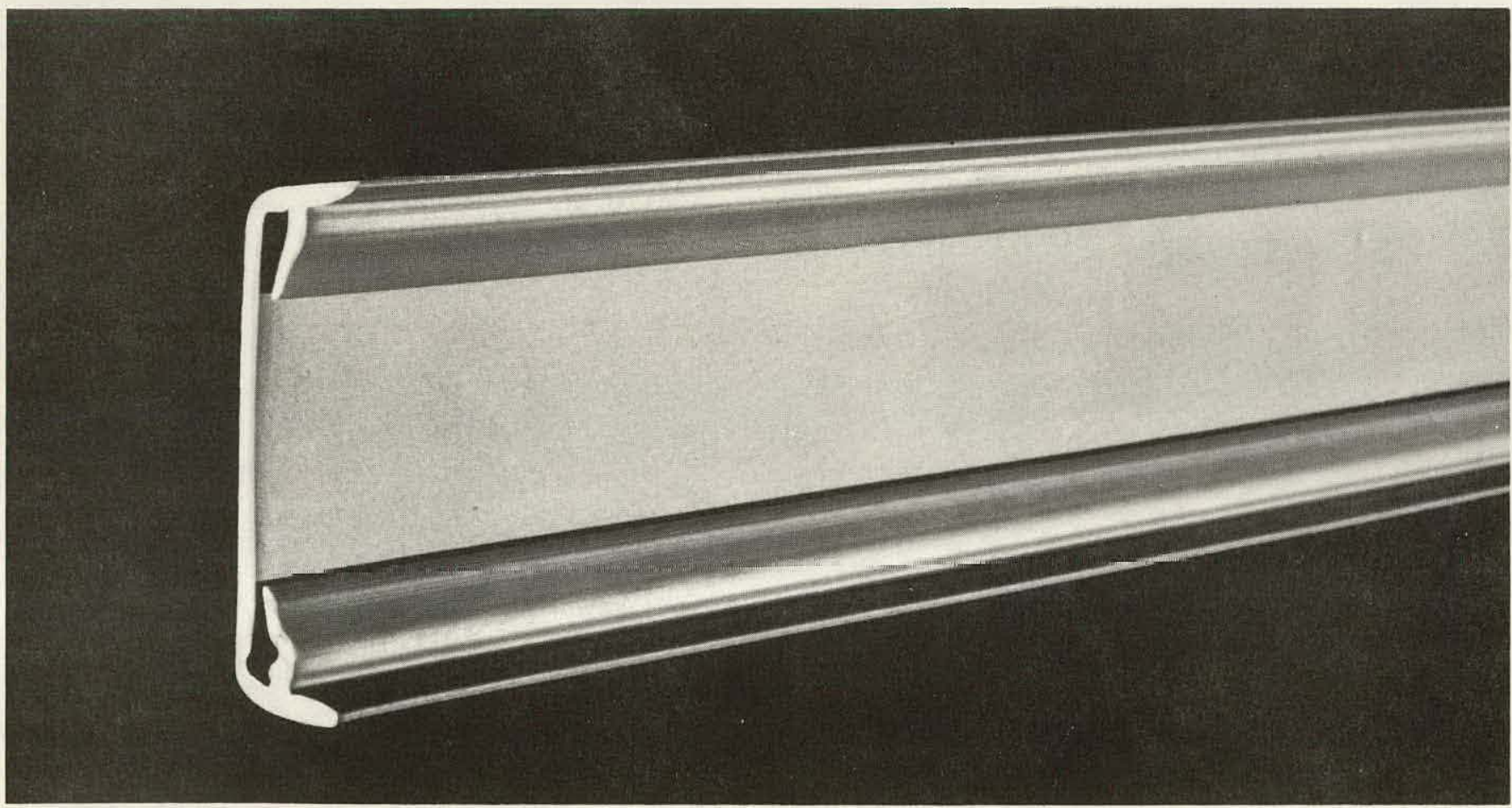


Figure 5: Recommended Screw Designs for Extrudable NORYL Resins (for reference only)

\section{1/2 INCH 24:1 TWO STAGE}

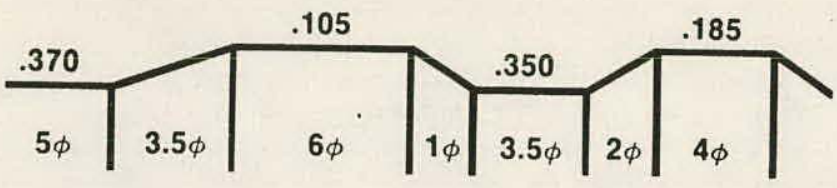

\section{1/2 INCH 24:1 TWO STAGE}

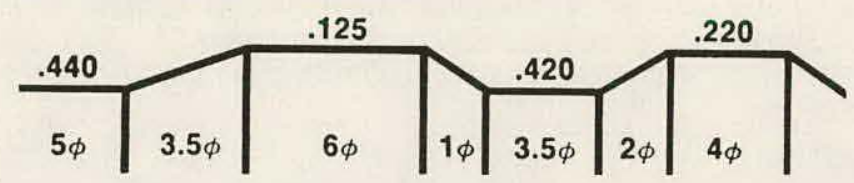

\section{1/2 INCH 24:1 TWO STAGE}

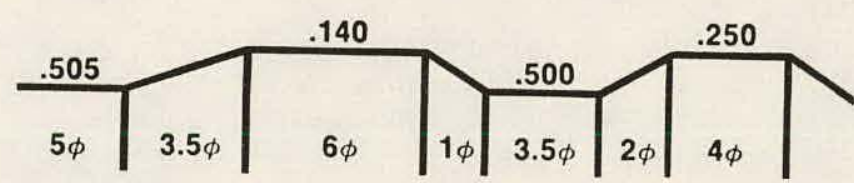

31⁄2 INCH 24:1 SINGLE STAGE

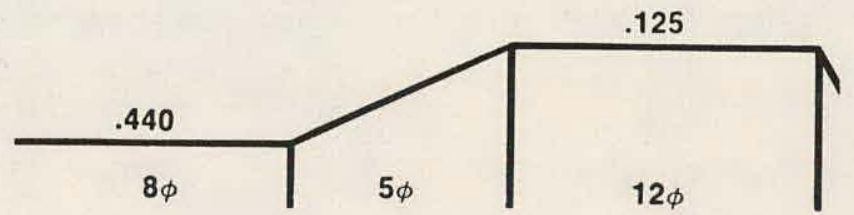

\section{Processing Guidelines}

The screw should not be left idle with melt in the extruder for more than a few minutes, to prevent carbonization and black spots.

- Satisfactory operation has been achieved without screen packs and with sizes as fine as 100 mesh.

Processing Temperatures:

NORYL EN-265 \&

NORYL ENG-265:

$420^{\circ}-500^{\circ} \mathrm{F}$

NORYL EN-212:

$390^{\circ}-450^{\circ} \mathrm{F}$

\section{Die}

Draw down ratios of $20-50 \%$ have been used with no effect on physical properties in the end part.

While NORYL resins do not emit harmful fumes or corrosive by-products, chrome-plating of inner die surfaces is recommended for optimum production rates and appearance.

Polished inner die surfaces are usually sufficient in most applications

- Streamlined dies are preferred, though shear dies are acceptable.

- NORYL resins exhibit die swell characteristics of $30 \%$ under the processing temperatures recommended above.

5. Cooling

Slow cooling of the NORYL resin extrudate is preferable to quick quenching to minimize residual stress

\section{Purging and Cleaning}

- Use conventional cleaning techniques with reground acrylics as the purge material.

- The die may be cleaned in a hot salt bath such as potassium chloride for 15 minutes. Remove all components that might be affected by the cleaner, such as the electrical heater. 


\section{Applications}

With their combination of properties, extrudable NORYL resins can improve the performance of many existing extruded plastic products. In addition, it can open new areas where metal can be replaced in extrusions for greater economy without sacrificing the required performance.

Typical applications include:

\section{Electrical}

Wiring splice devices

Protective shields

Wire enclosures/Conduit

Electrical appliance enclosures, mountings and escutcheons

\section{Utility/Construction}

Cooling tower scrubber vanes \& mist eliminators

Bus bar sleeves

Building products

Protective cable covers

Ground wire covers

\section{Lighting}

Ceiling light housings

Lighting tracks

Enclosures

\section{Technical Assistance}

The NORYL Products Section has qualified technical personnel ready to assist you at every phase of product development, from design through production.

\section{Design}

Capitalize on the high performance of NORYL resins to develop designs using thinner wall sections than are possible with FR ABS or PVC. NORYL design engineers will work with you on the most efficient design that makes the most of the material.

\section{Agency Approval}

All NORYL resins carry broad recognition by Underwriters' Laboratories and the Canadian Standards Association. The agency specialists can help speed your product through the required approvals for fast market introduction.

\section{Extrusion}

Extrusion process specialists can assist you in insuring optimum processing conditons for NORYL resins, to help you maximize the material's productivity.

\section{Finishing}

If your product requires painting or other secondary finishing, you can turn to NORYL Products Section personnel for the latest systems, techniques and suppliers.

For further information, contact:

Extrusion Technical Team

NORYL Products Section

General Electric Plastics

Selkirk, New York 12158 
Inasmuch as General Electric Company has no control over the use to which others may put the material, it does not guarantee that the same results as those described herein will be obtained. Each user of the material should make his own tests to determine the material's suitability for his own particular use. Statements concerning possible or suggested uses of the materials described herein are not to be construed as constituting a license under any General Electric patent covering such use or as recommendations for use of such materials in the infringement of any patent.

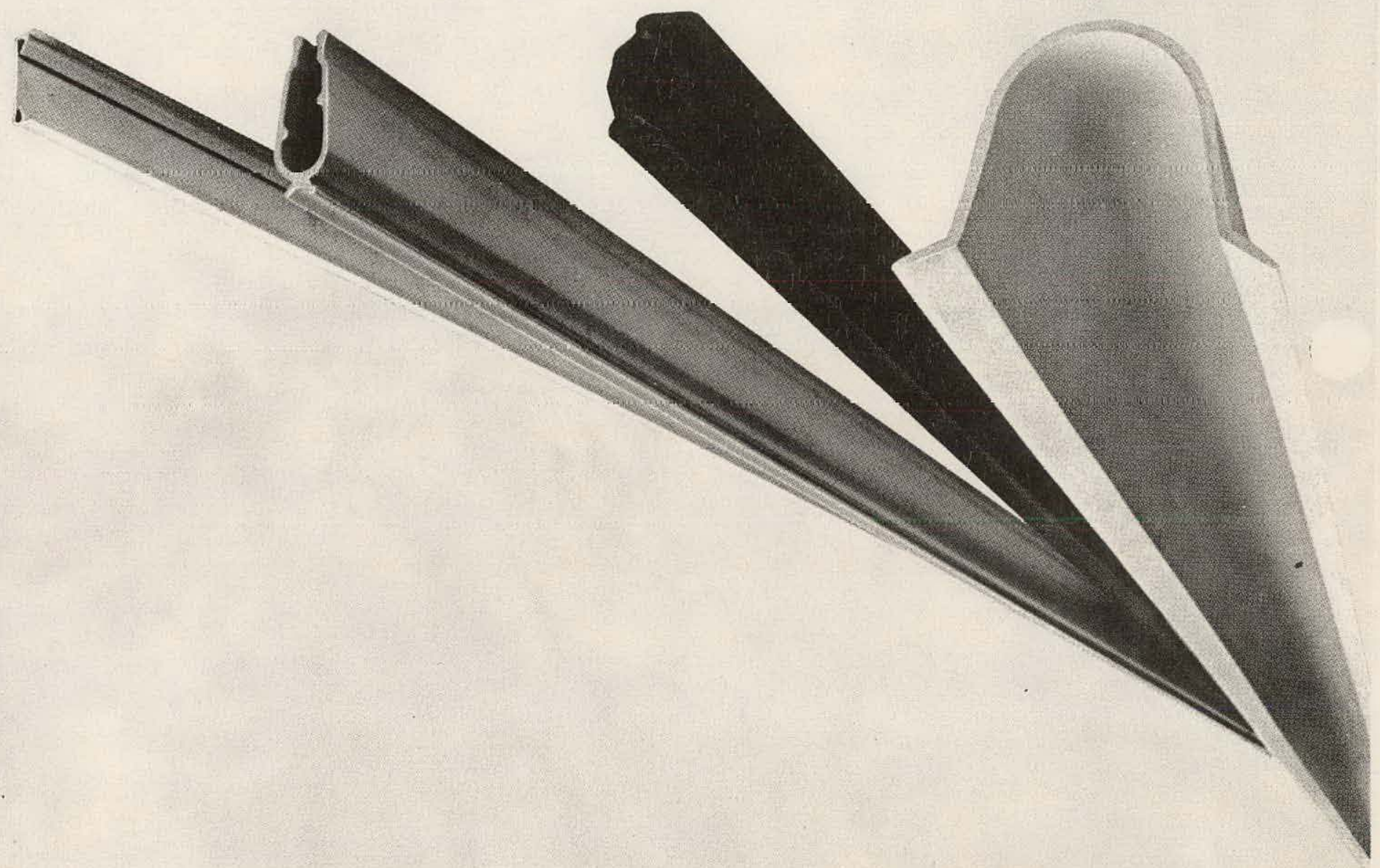

WORLD LEADER IN ENGINEERING PLASTICS

$\angle E X A N{ }^{\oplus}$ NORYL ${ }^{\oplus}$ GENAL ${ }^{\circledast}$ VALOX

\section{GENERAL ELECTRIC}

PLASTICS DEPARTMENT

NORYL AVE., SELKIRK, N. Y. 12158 
These pages contained copyrighted material. For information on Tremco POLYshim TM Tape contact: Tremco, 10701 Shaker Blvd, Cleveland, OH 44104. 


\section{Royalene EPDM "Crackless Rubber."}

For extended service life of rubber products.

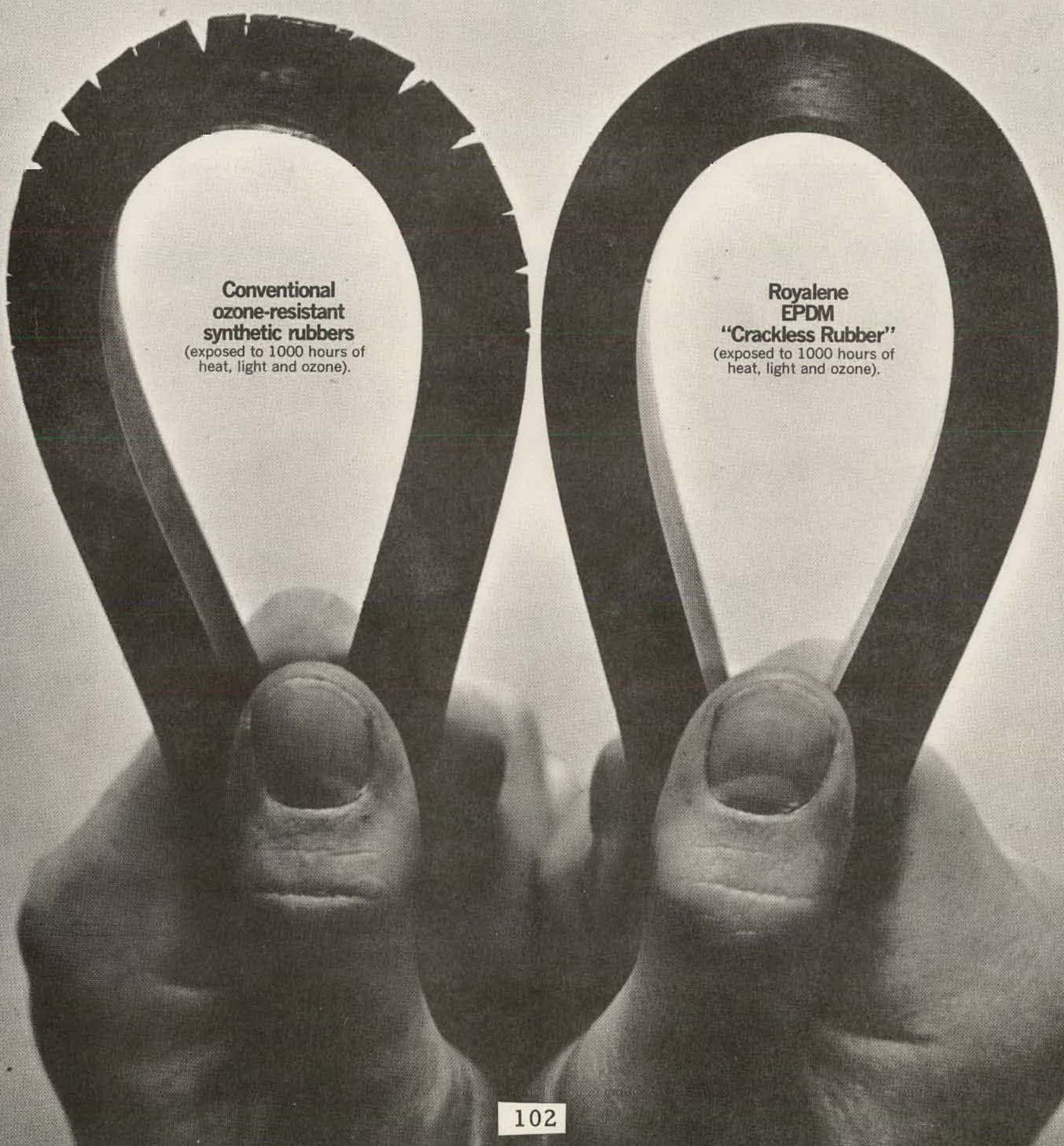




\section{Royalene EPDM is a general-purpose rubber that has many uses.}

Royalene can be used for a wide variety of products.

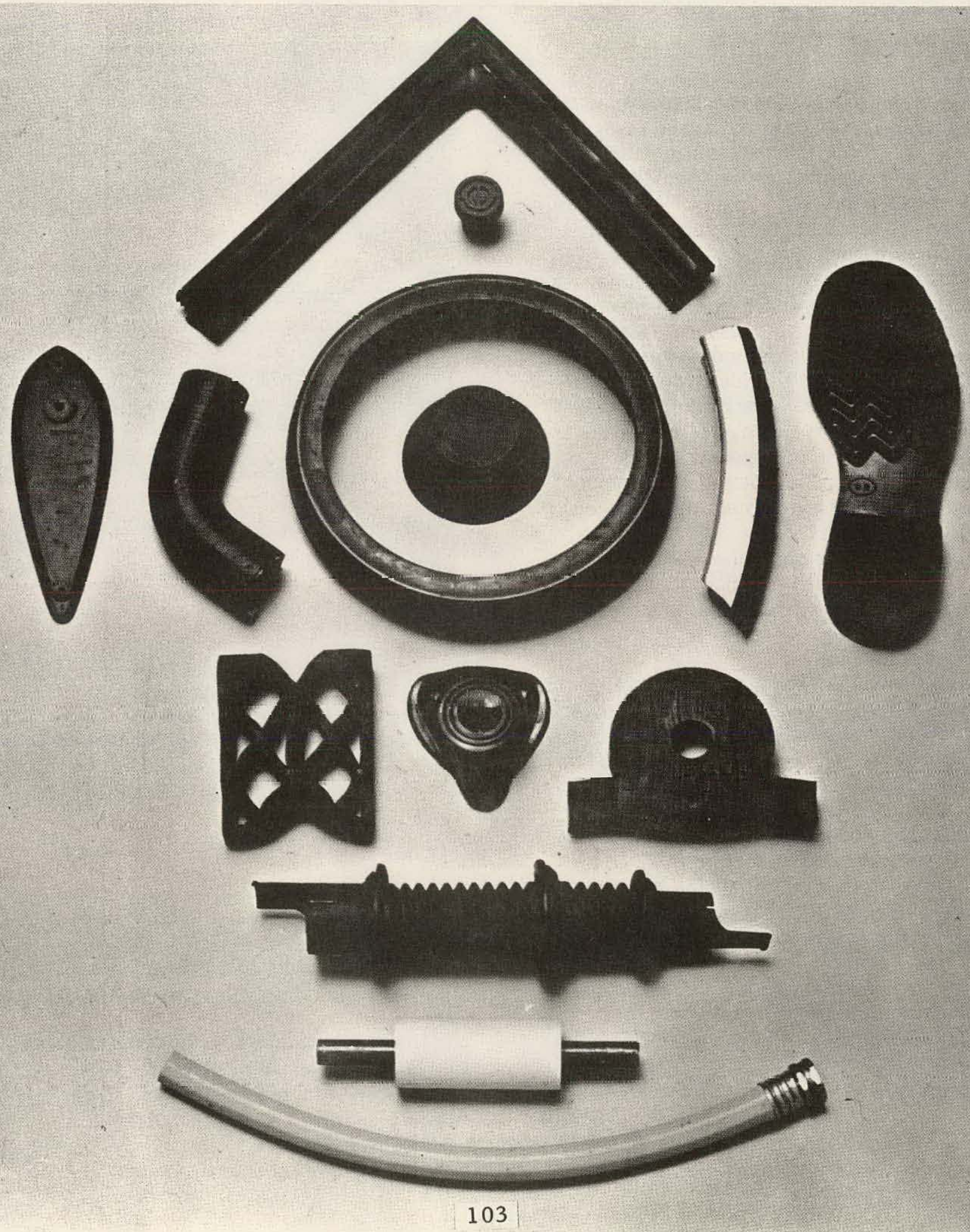


Royalene EPDM (a terpolymer of ethylene, propylene and a controlled amount of non-conjugated diene) has proved to be a materials break-through of significant proportions because it can be easily made into a variety of objects that resist weather and ozone degradation far longer than was ever possible before.

\section{Automotive applications.}

Royalene has demonstrated its superiority in many automotive applications presently using SBR, natural, butyl and other rubbers. Therefore, Royalene has gained wide acceptance for many engineering uses in the automotive industry: sealing weather strips (windshield, back lights, body shims, bumper guards), cellular sealing strips (door weather strip, deck lid seals), windshield wiper blades, windshield wiper tubing, hose tubes and covers (both heater and radiator), brake cups, shocks, pedals, specialty coated fabric auto topping, motor mounts, ignition cable insulations, wiring grommets, miscellaneous gaskets, dust seals and boots.

EPDM is also keeping tire whitewalls white. Practically all the EPDM sold for this purpose is Uniroyal's "Crackless Rubber" (sold under the registered tradename Royalene).

Appliance applications.

In the appliance field, ability to resist cracking after repeated flexing, its wide temperature range and resistance to acids and alkalis, ideally lends itself to use for many washer, dryer, refrigerator and other appliance parts including hoses, seals, door gasketings and appliance wire.

\section{Wire and cable applications.}

Since Royalene can be specially formulated for excellent physicals together with flame, abrasion, weathering and moisture resistance, wire and cable jacketing represents a sound application for this material in many cases.

An added feature of Royalene is that its unique combination of properties makes a true rubber-like integral $600 \mathrm{~V}$ insulation and jacket possible for the first time.

\section{Other applications.}

Royalene resists many chemicals. It is finding wide applications in tank liners, hoses, and other uses requiring resistance to phosphate esters, ketones,

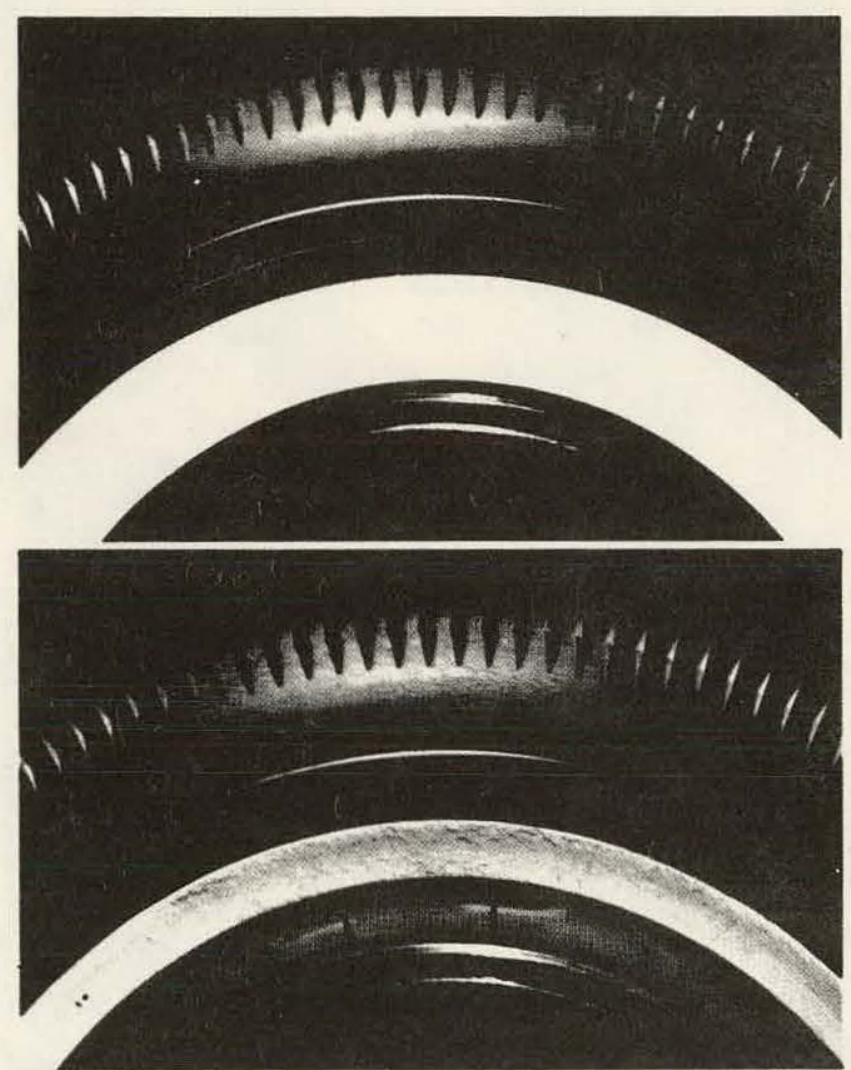

Both tires were aged 18 months. The one that didn't crack (top) contains Royalene, the "Crackless Rubber." Most whitewall and cover strips now contain Royalene.

glycols and alcohols. It is especially useful for long maintenance-free service in the storage of peroxides and caustic soda.

The excellent water resistance of Royalene has led to its widespread use for water conservation and for prevention of contamination and leakage. Such applications include the lining of reservoirs, irrigation ditches and brine storage pits and the waterproofing of underground structures. 


\section{Royalene EPDM \\ has physical properties superior to other general-purpose rubbers.}

Comparison of Royalene EPDM with other commonly used polymers.

\begin{tabular}{|c|c|c|c|c|c|c|c|}
\hline \multicolumn{2}{|c|}{ Property } & Royalene & Butyl & Neoprene & Polybutadiene & $\begin{array}{l}\text { Polyisoprene; } \\
\text { Natural rubber }\end{array}$ & SBR \\
\hline \multicolumn{2}{|c|}{ Hardness range; shore $\mathrm{A}$} & 40 to 90 & 40 to 75 & 30 to 95 & 40 to 90 & 30 to 90 & 40 to 90 \\
\hline \multicolumn{2}{|c|}{ Specific gravity } & 0.865 & 0.92 & 1.23 & 0.91 & 0.93 & 0.94 \\
\hline \multicolumn{2}{|c|}{ Tensile strength; black loaded (psi) } & 3500 & 3000 & 3500 & 2000 & 3500 & 2500 \\
\hline \multicolumn{2}{|c|}{ Tensile strength; pure gum (psi) } & 500 & 2000 & 3500 & 500 & 3000 & 400 \\
\hline \multicolumn{2}{|c|}{ Cold flow } & $E$ & $F$ & $E$ & $P$ & $\mathrm{P}^{*} ; \mathrm{E}^{\dagger}$ & $E$ \\
\hline \multicolumn{2}{|c|}{ Color stability } & $E$ & $G$ to $E$ & $\mathrm{P}$ & $G$ to $E$ & $G$ to $E$ & $G$ to $E$ \\
\hline \multicolumn{2}{|c|}{ Compression set } & G & $F$ & G & G & $E$ & $E$ \\
\hline \multicolumn{2}{|c|}{ Cord adhesion } & G & $\mathrm{P}$ to $\mathrm{F}$ & G & G & G & G \\
\hline \multicolumn{2}{|c|}{ Cure rate } & G & $S$ & M & $E$ & $E$ & $E$ \\
\hline \multicolumn{2}{|c|}{ Dynamic properties } & $G$ to $E$ & $P$ & G & $E$ & $E$ & $G$ \\
\hline \multicolumn{2}{|c|}{ Electrical properties } & $E$ & $E$ & $P$ & G & $G$ & G \\
\hline \multicolumn{2}{|c|}{ Loading; black } & $E$ & $\mathrm{P}$ & G & $\mathrm{G}$ & $G$ to $E$ & $\mathrm{G}$ \\
\hline \multicolumn{2}{|c|}{ Loading; oil } & $E$ & $\mathrm{P}$ & $\mathrm{F}$ & $F$ to $G$ & $\mathrm{G}$ & $F$ to $G$ \\
\hline \multicolumn{2}{|c|}{ Tack } & G & $F$ & G & $\mathrm{F}$ & $E$ & $F$ to $G$ \\
\hline \multirow{19}{*}{$\begin{array}{c}\text { Resistance } \\
\text { to: }\end{array}$} & Abrasion & G & $\mathrm{F}$ & $E$ & G & $\mathrm{G}$ to $\mathrm{E}$ & $\mathrm{G}$ \\
\hline & Acids & $G$ to $E$ & $E$ & G & G & $\mathrm{G}$ & G \\
\hline & Bases & $\mathrm{G}$ to $\mathrm{E}$ & $E$ & G & G & G & G \\
\hline & Cold & $E$ & $E$ & $\mathrm{~F}$ & G & $E$ & $F$ to $G$ \\
\hline & Flame & RSC & RSC & G & RSC & RSC & RSC \\
\hline & Gas permeation & $\mathrm{F}$ & $E$ & G & $F$ & $F$ & $\mathrm{~F}$ \\
\hline & Heat & $E$ & G & G & G & $\mathrm{F}$ & $\mathrm{F}$ \\
\hline & Oils; animal \& vegetable & G & $E$ & G & $\mathrm{F}$ & $F$ & $\mathrm{~F}$ \\
\hline & Oils; mineral & NS & NS & G & NS & NS & NS \\
\hline & Ozone & $E$ & $E$ & G & $P$ & $\mathrm{P}$ & $\mathrm{F}$ \\
\hline & Solvents; aliphatic & $\mathrm{P}$ & $\mathrm{P}$ & $G$ & $\mathrm{P}$ & $\mathrm{P}$ & $\mathrm{P}$ \\
\hline & Solvents; aromatic & $\mathrm{P}$ & $\mathrm{P}$ & $\mathrm{F}$ & $\mathrm{P}$ & $P$ & $P$ \\
\hline & Solvents; chlorinated & $\mathrm{P}$ & $\mathrm{P}$ & $\mathrm{P}$ & $\mathrm{P}$ & $P$ & $P$ \\
\hline & Solvents; lacquer & $\mathrm{P}$ & $\mathrm{P}$ & $\mathrm{P}$ & $P$ & $\mathrm{P}$ & $P$ \\
\hline & $\begin{array}{l}\text { Solvents; oxygenated } \\
\text { (i.e., ketones) }\end{array}$ & G & G & $\mathrm{P}$ & $P$ & G & $\mathrm{P}$ \\
\hline & Steam & E & $E$ & G & G & $\mathrm{G}$ & G \\
\hline & Tearing & G & G & G & $\mathrm{F}$ & $\mathrm{G}$ to $\mathrm{E}$ & $\mathrm{F}$ \\
\hline & Water & $E$ & $E$ & $\mathrm{~F}$ & $E$ & $E$ & $E$ \\
\hline & Weather & $\mathrm{E}$ & $E$ & $E$ & $\mathrm{P}$ & $\mathrm{F}$ & $\mathrm{F}$ \\
\hline
\end{tabular}


Royalene has many properties superior to other commonly used elastomers. The table at the left shows this comparison with SBR, natural rubber and other polymers.

Vulcanizates of Royalene exhibit many outstanding properties.

\section{Lower specific gravity.}

The specific gravity of Royalene is lower than all other rubbers. Consequently, Royalene offers a higher yield of fabricated parts per pound.

Final product cost also benefits by the ability of Royalene to be highly extended with inexpensive oils and blacks.

Petroleumroils suitable for the extension of Royalene are less expensive than the esters normally used to plasticize neoprene, butyl, or acrylic rubbers. In addition, Royalene can accept larger amounts of fillers than other rubbers with good retention of physical properties.

\section{Retains properties at high temperatures.}

Royalene is serviceable for extended periods of continuous use at temperatures in excess of 300 degrees $\mathrm{F}$ and has shown good results in intermittent uses as high as 400 degrees $F$.

Such vital properties as resilience, tensile strength, elongation and hardness are largely retained in aging tests at elevated temperatures. Royalene is far superior to any other general purpose synthetic rubber on high temperature resistance.

Retains properties at low temperatures.

Royalene retains its flexibility at extremes that shatter most rubber materials.

Royalene compounds remain serviceable at temperatures as low as minus 70 degrees $F$.

Other benefits.

Other benefits of Royalene are excellent processing, good to excellent physical properties, excellent weather and ozone resistance, excellent electrical properties, good abrasion resistance, good set properties and excellent resistance to polar liquids such as water, phosphate esters, ketones.

Royalene EPDM is commercially available from Uniroyal Chemical in numerous types to suit the varying demands of rubber compounders.

\begin{tabular}{|c|c|c|c|c|}
\hline \multicolumn{5}{|c|}{ Ultraviolet aging effects } \\
\hline \multirow{2}{*}{$\begin{array}{l}\text { U.V. aging } \\
\text { (hours) }\end{array}$} & \multicolumn{4}{|c|}{ Polymers } \\
\hline & Royalene & Butyl & Neoprene & SBR \\
\hline 2 & NC & NC & NC & EFC \\
\hline 24 & NC & EFC & NC & EFC \\
\hline 48 & NC & EFC & EFC & EFC \\
\hline 100 & NC & VVS & VVS & EFC \\
\hline 200 & NC & VS & VS & EFC \\
\hline 340 & NC & S & VS & EFC \\
\hline $\begin{array}{l}\text { Sample } \\
\text { curing }\end{array}$ & $\begin{array}{l}30 \mathrm{~min} . \\
\text { at } 320^{\circ} \mathrm{F}\end{array}$ & $\begin{array}{l}30 \mathrm{~min} \text {. } \\
\text { at } 307^{\circ} \mathrm{F}\end{array}$ & $\begin{array}{l}30 \min \text {. } \\
\text { at } 307^{\circ} \mathrm{F}\end{array}$ & $\begin{array}{l}15 \min \text {. } \\
\text { at } 307^{\circ} \mathrm{F}\end{array}$ \\
\hline \multirow{5}{*}{ Code } & \multicolumn{4}{|c|}{$\mathrm{NC}=$ no crazing visible at $20 \times$ magnification } \\
\hline & \multicolumn{4}{|c|}{$\begin{aligned} \mathrm{EFC}= & \text { extremely fine crazing visible at } 20 \times \\
& \text { magnification. }\end{aligned}$} \\
\hline & \multicolumn{4}{|c|}{$\begin{aligned} \text { VVS }= & \text { very, very slight cracking visible at } \\
& 20 \times \text { magnification. }\end{aligned}$} \\
\hline & \multicolumn{4}{|c|}{$\begin{aligned} & \mathrm{VS}= \text { very slight cracking visible at } 20 \times \\
& \text { magnification. }\end{aligned}$} \\
\hline & \multicolumn{4}{|c|}{$\begin{aligned} \mathrm{S}= & \text { slight cracking visible without } \\
& \text { magnification. }\end{aligned}$} \\
\hline
\end{tabular}

Table above shows outstanding ultraviolet aging of Royalene compared to other polymers. Test made on Atlas Weatherometer with 1 -inch sample bent double on self. 


\section{Royalene EPDM has many processing advantages and premium properties.}

Rheometer curves show outstanding cure rates of Royalene compared to SBR.

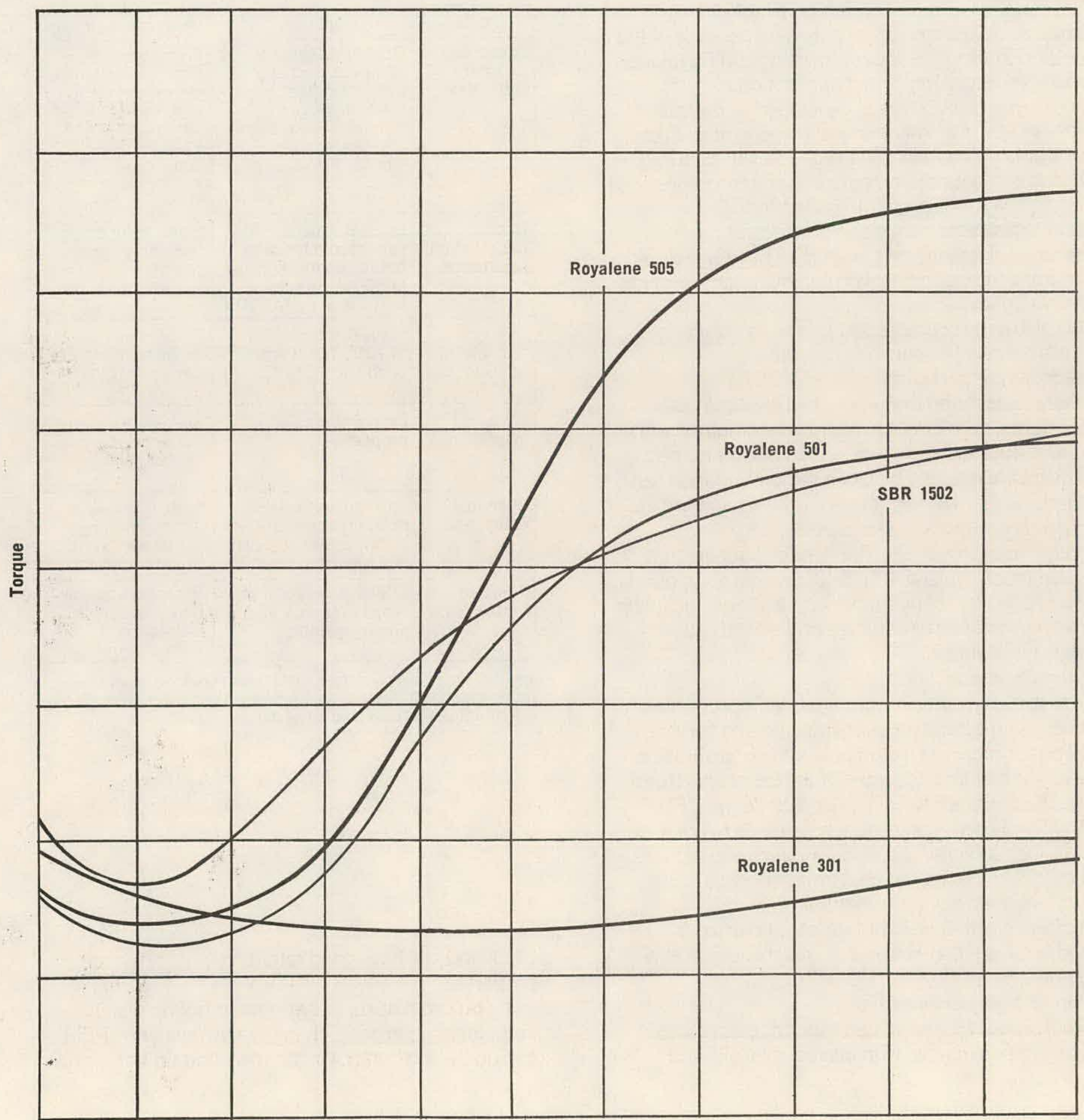


The various types of Royalene available from Uniroyal have replaced other polymers because of the superior performance and/or lower cost of Royalene in a wide variety of important applications.

The Royalene 500 series, developed by our poly. mer chemists, is a new chemical composition which retains all of the outstanding properties of existing Royalene compounds and yet gives you the fastest curing EPDM rubbers on the market today.

\section{Easy to process.}

Because of its inherent properties Royalene does not require compounding with expensive antioxidants in many applications.

It is also sulfur curable and free from objectionable odor, as well as peroxide curable.

\section{Reduces per part cost.}

Users have found that when the Royalene 500 series of fast cure EPDM rubbers are combined with Royalene 400 series of oil-extended polymers, per part costs are reduced because the combination can readily be vulcanized on conventional equipment with good control and a fast cure rate.

With increasing use of oil-extended rubbers, it is believed that Royalene $400 / 500$ low cost compounds could be used for many rubber applications, including many types of open cell sponge and closed cell sponge applications.

\section{Extends product life.}

Due to its remarkable combination of properties, Royalene can extend product shelf life and service life. Those properties include resistance to abrasion, ozone, weather and extremes of temperatures (from minus 70 degrees $F$ to as high as 400 degrees $F$ ).

And Royalene has excellent resistance to polar liquids such as water, phosphate esters and ketones.

In addition to superior performance, Royalene also offers great savings potential.

It offers a higher yield of fabricated parts per pound because of all rubbers, it has the lowest specific gravity: 0.865 .

\section{Can be highly extended.}

Final product cost also benefits since Royalene can be highly extended with inexpensive oils and

\begin{tabular}{|c|c|c|}
\hline Properties & Features & Advantages in use \\
\hline $\begin{array}{l}\text { Ozone and } \\
\text { weather } \\
\text { resistance. }\end{array}$ & $\begin{array}{l}\text { Ozone protective } \\
\text { additives normally } \\
\text { used for other } \\
\text { rubbers are not } \\
\text { required in black and } \\
\text { non-black EPDM } \\
\text { vulcanizates. }\end{array}$ & $\begin{array}{l}\text { Elimination of } \\
\text { strain limitations, } \\
\text { allows less costly } \\
\text { and restrictive } \\
\text { design. Better } \\
\text { appearance. } \\
\text { Longer product, } \\
\text { shelf and service } \\
\text { life. }\end{array}$ \\
\hline $\begin{array}{l}\text { Heat } \\
\text { degradation } \\
\text { resistance. }\end{array}$ & $\begin{array}{l}\text { Some Royalene EPDM } \\
\text { serviceable for ex- } \\
\text { tended continuous use } \\
\text { at } 300^{\circ} \mathrm{F} \text {, intermit. } \\
\text { tent use at up to } 400^{\circ} \mathrm{F} \text {. }\end{array}$ & $\begin{array}{l}\text { Suitable for engine } \\
\text { compartment } \\
\text { components. }\end{array}$ \\
\hline $\begin{array}{l}\text { Low- } \\
\text { temperature } \\
\text { utility. }\end{array}$ & $\begin{array}{l}\text { Stays flexible below } \\
-70^{\circ} \mathrm{F} \text {. Won't em. } \\
\text { brittle at }-100^{\circ} \mathrm{F} \text {. }\end{array}$ & $\begin{array}{l}\text { Permits use in } \\
\text { broad temperature } \\
\text { range: }-100^{\circ} \mathrm{F} \\
\text { to }+400^{\circ} \mathrm{F} \text {. }\end{array}$ \\
\hline $\begin{array}{l}\text { Electrical } \\
\text { insulation. }\end{array}$ & $\begin{array}{l}\text { Excellent insulating } \\
\text { properties. }\end{array}$ & $\begin{array}{l}\text { Suitable for many } \\
\text { power and control } \\
\text { applications. }\end{array}$ \\
\hline $\begin{array}{l}\text { Chemical } \\
\text { resistance. }\end{array}$ & $\begin{array}{l}\text { Particularly resists } \\
\text { polar liquids like } \\
\text { water, esters, glycols } \\
\text { and ketones. }\end{array}$ & $\begin{array}{l}\text { Suited for use in } \\
\text { heating.cooling } \\
\text { components and } \\
\text { brake systems. }\end{array}$ \\
\hline $\begin{array}{l}\text { Dynamic } \\
\text { properties. }\end{array}$ & $\begin{array}{l}\text { Effective over a broad } \\
\text { range of temperatures } \\
\text { and frequencies. }\end{array}$ & $\begin{array}{l}\text { Potential applica- } \\
\text { tion as vibration } \\
\text { isolators and } \\
\text { body mounts. }\end{array}$ \\
\hline
\end{tabular}

Various types of Royalene EPDM have replaced other poly. mers because of their superior properties, lower cost, outstanding features and advantages in use.

black and still have good retention of its physical properties.

If you use natural or synthetic rubbers of any kind, for any purpose, chances are Royalene EPDM can do the job better. Or cheaper. And probably both. 


\section{JNIROYAL}

Uniroyal Chemical, Division of Uniroyal, Inc., Naugatuck, Connecticut 06770.

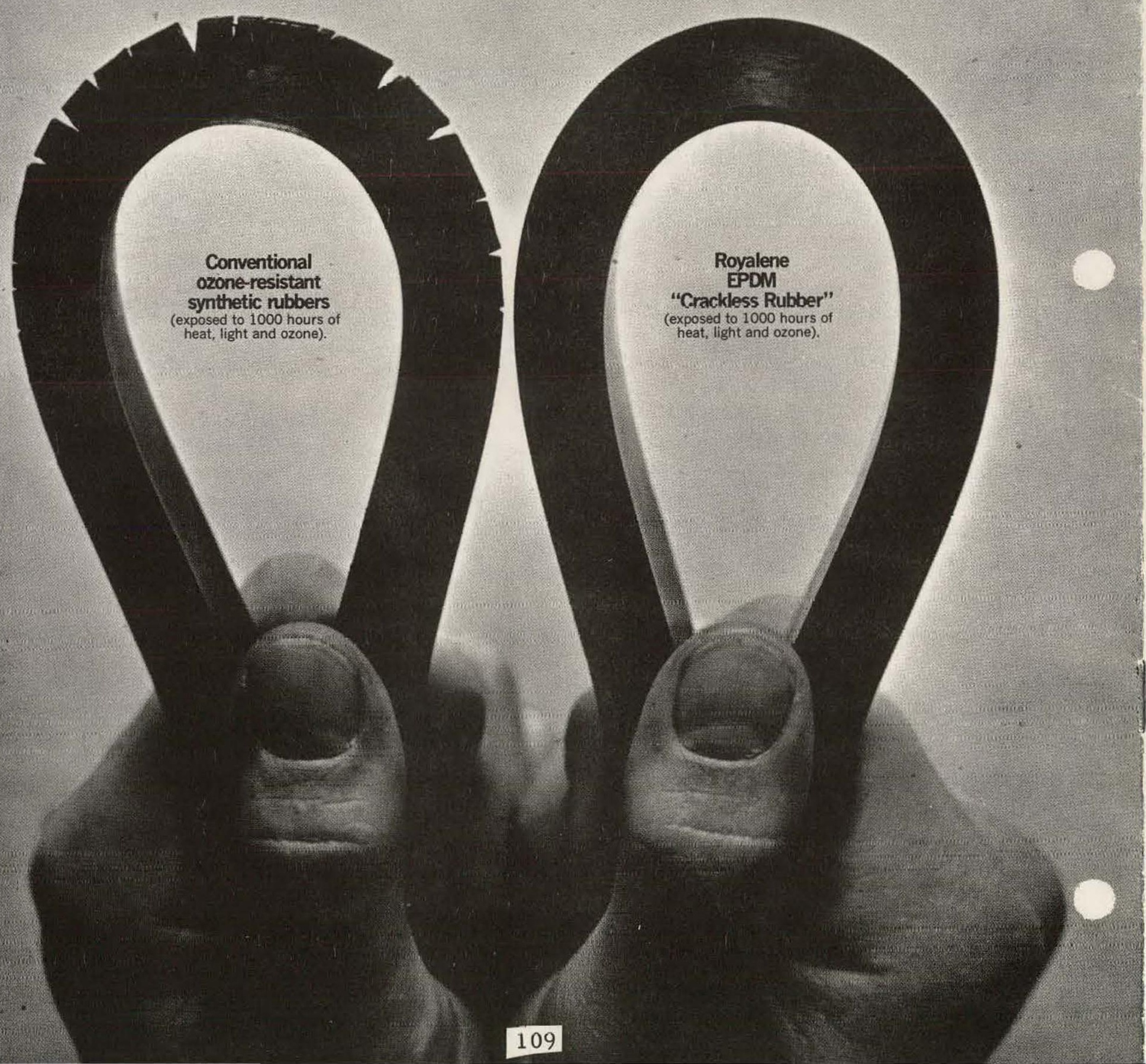




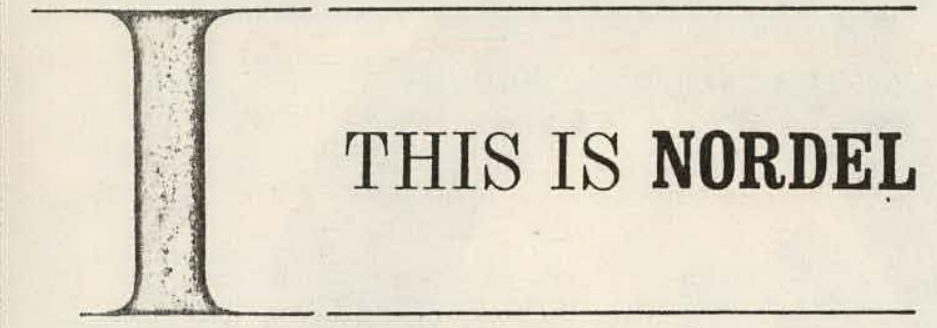

What is NORDEL? How does it differ from other synthetic rubbers? What new opportunities does it offer to the designer and user of rubber parts? Answers to these and other questions are explored in this profile of an important engineering material.
NORDEL

is a synthetic rubber developed by $\mathrm{Du}$ Pont and supplied to rubber goods manufacturers throughout North America and many other parts of the world. In chemical terms, it is a terpolymer of ethylene, propylene and a nonconjugated diene-a hydrocarbon-based elastomer that can be processed and vulcanized by standard rubberindustry techniques. Rubber chemists usually refer to this class of elastomer by the initials EPDM.

To the specifying engineer, NORDEL might be better defined as a general-purpose synthetic rubber with premiumperformance properties. It offers the broad utility and many of the good properties of such long-familiar materials as natural rubber and SBR (styrene-butadiene synthetic rubber); like them, it has found use in a wide range of industrial and consumer products.

The distinctive difference that sets NoRDEL apart from other general-purpose rubbers is performance in categories of properties (particularly resistance to environmental conditions) usually found only in special-purpose elastomers.

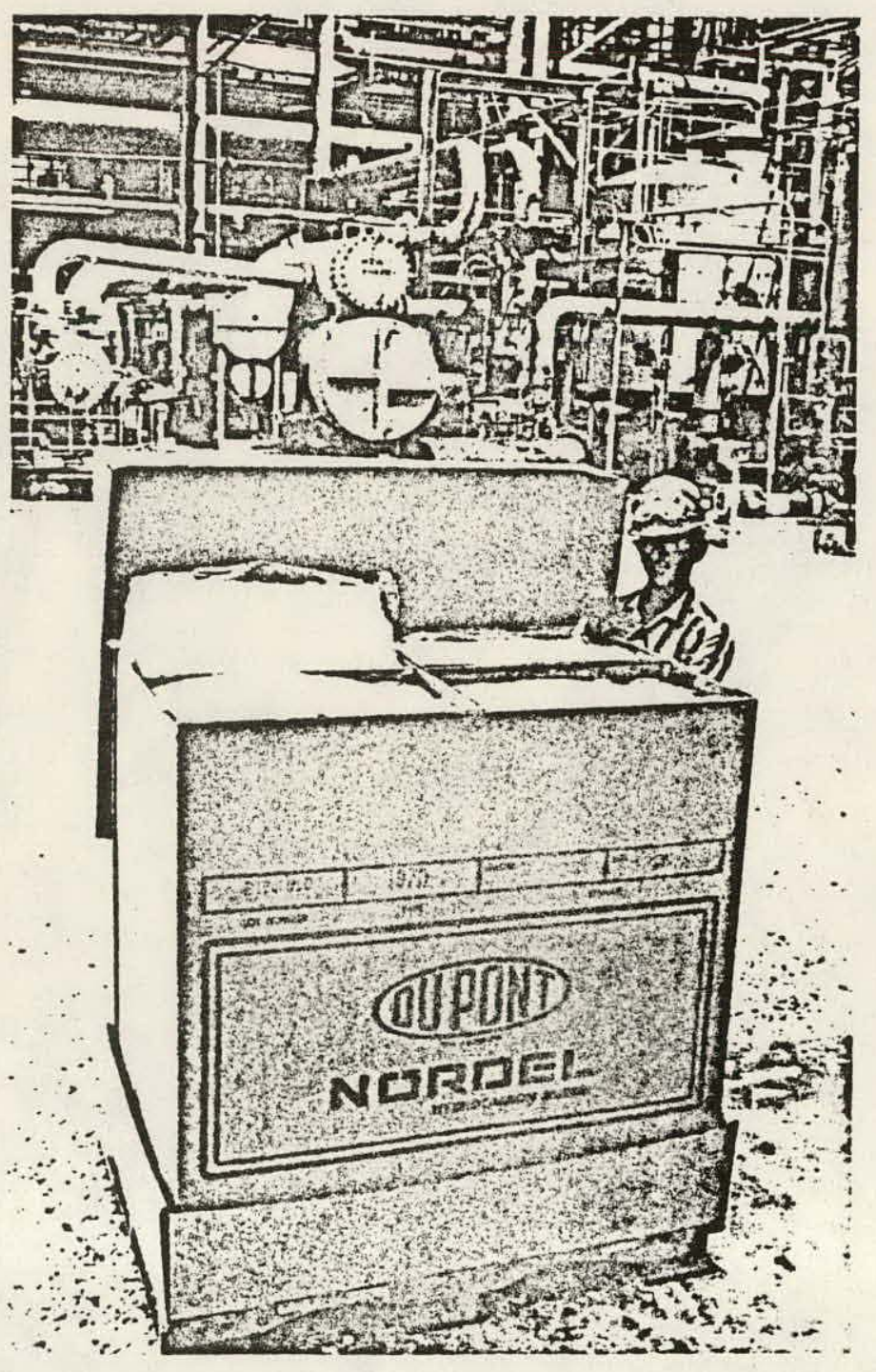

This is NoRdel hydrocarbon rubber as Du Pont produces it-a basic raw material which other manufacturers compound and process into finished products for a range of industrial and consumer uses. 


\section{HOW DU PONT NORDEL. COMPARES WITH} OTHER GENERAL.PURPOSE ELASTOMERS*

\begin{tabular}{|c|c|c|c|}
\hline Property & NORDEL & Natural Rubber & SBR \\
\hline Specific Gravity & 0.85 & $0.93^{\prime}$ & 0.94 \\
\hline Tensile Strength & good to excellent & excellent & good to excellen \\
\hline Dynamic Properties & excellent & excellent & good \\
\hline Color Stability & excellent & good to excellent & good to excellen \\
\hline Electrical Properties & excellent & good & good \\
\hline \multicolumn{4}{|l|}{ Resistance to: } \\
\hline Weather & excellent & fair & fair \\
\hline Ozone & excellent & poor & fair \\
\hline Heat & excellent & fair & fair to good \\
\hline Cold & good to excellent & good to excellent & fair to good \\
\hline \multicolumn{4}{|l|}{ Chemicals } \\
\hline Acids & good to excellent & good & good \\
\hline Bases & good to excellent & good & good \\
\hline Oils & poor & poor & poor \\
\hline Abrasion & good to excellent & good to excellent & good \\
\hline Tearing . & good & good to excellent & good \\
\hline Steam & excellent & good & good \\
\hline Compression Set & good & excellent & excellent \\
\hline Flame & poor & poor & poor \\
\hline
\end{tabular}

Ratings in this chart are based on performance of conventional compounds of NORDEL, natural rubber and SBR. For each elastomer, any given property can usually be improved by selective compounding.

\section{PERFORMANCE}

PROPERTIES The performance abilities of vulcanized NORDEL are superior to those of any other type generalpurpose rubber. In some characteristics (notably ozone, weather, heat and steam resistance), NoRDEL actually performs on a level with many specialty elastomers.

Just how "premium" are the performance characteristics of NORDEL? The table at left partially answers this question by comparing selected properties of NORDEL with those of natural rubber and SBR. From this quick comparison, the relative superiority of the Du Pont elastomer over conventional general-purpose rubbers is quite evident. To better illustrate degree of performance, here are some brief quantitative observations:*

NORDEL is virtually immune to attack by ozone. In laboratory tests at concentrations as high as 10,000 parts ozone per hundred million parts of air, technicians have never been able to damage a sample of vulcanized NORDEL. This is an inherent characteristic of the ethylene-propylenediene terpolymer; the ozone resistance of NORDEL is not dependent upon the use of chemical additives.

NORDEL has outstanding heat resistance. Products of NORDEL can be compounded for service at temperatures of $300-350^{\circ} \mathrm{F}$., well above the capabilities of either SBR or natural rubber. Intermittent service from $350-400^{\circ} \mathrm{F}$. can be obtained with these heat-resistant formulations, and even higher temperatures can be tolerated for brief exposure periods.

\footnotetext{
-Section 3 of this report (pages 15-19) discusses properties of NORDEL in more complete detail.
} 


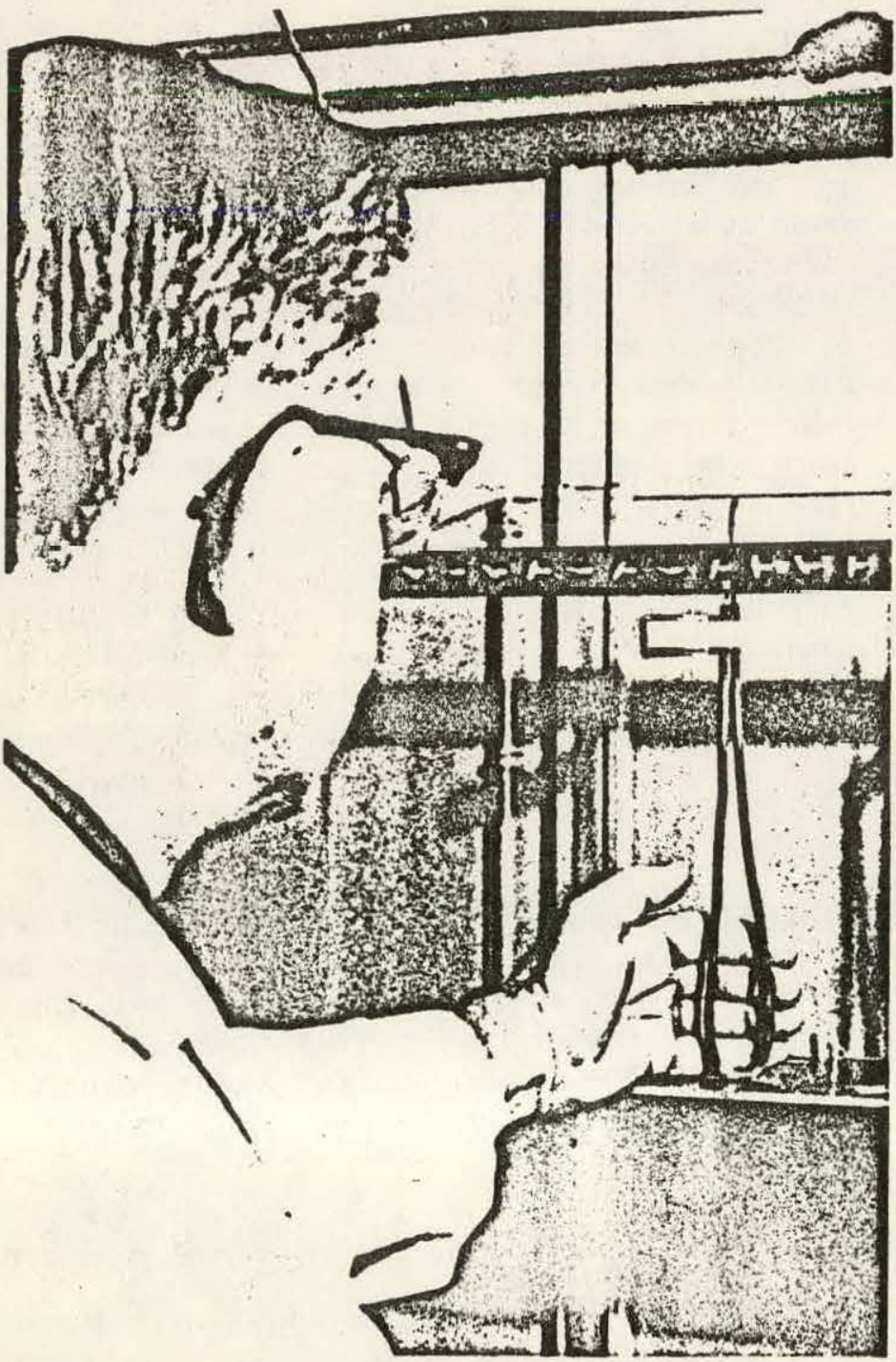

NORDEL stay:s flexible at low temperatures. Clash-Berg stiffness values of typical products usually fall between $-60^{\circ} \mathrm{F}$ and $-70^{\circ} \mathrm{F}$. Impact brittle points are usually $-90^{\circ} \mathrm{F}$. or below.

NORDEL has exceptional resistance to steam. Service testing has shown that commercially made steam hose of NORDEL in round-the-clock use has a life of one year (more than 8.000 hours) carrying 150 psig saturated steam $\left(366^{\circ} \mathrm{F}\right.$.), and three months (more than 2.000 hours) carrying 250 psig saturated stcam $\left(407^{\circ} \mathrm{F}\right.$.). This is several times the life of hoses made from other elastomers.

Other important performance characteristics of NORDEL include dynamic properties that remain constant over a wide temperature range: resistance to weather and sunlight aging (in colored as well as black products); excellent electrical properties: chemical resistance and good mechanical properties. Since NORDEL is basically a hydrocarbon, it is not resistant to flame or petroleum-based oils.

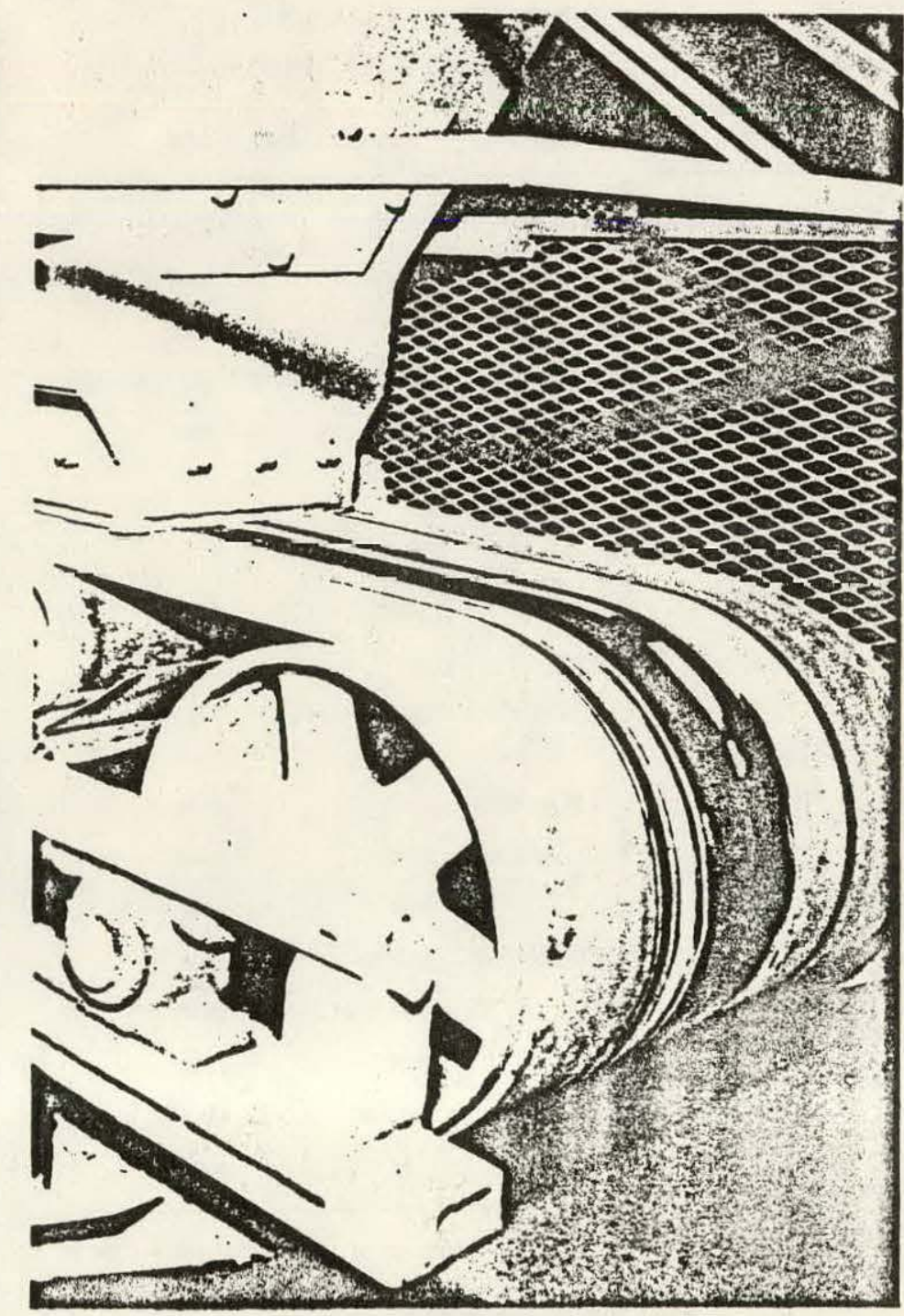

Both laboratory testing and actual use in commercial service have established the performance advantages of products made from NoRDEL. Left: Electrical wire insulation is undamaged after 10,000-volt corona test. Right: Hot-chemicals belt is still excellent after 4 years' service. 
NORDEL ${ }^{3}$ hydrocarbon rubber is processed and vulcanized into finished parts by the same techniques and with the same equipment "sed for other general-purpose rubbers. Compounded material is molded, extıuded or calendered in routine fashion; final products are vulcanized by curing methods standard in the rubber industry. Products made of NORDEL move through the production line as easily as products made of any other type of elastomer, natural or synthetic. Cellular products also are made by conventional methods and may be of either the open- or closed-cell variety.

This, then, is NORDEL hydrocarbon rubber-a general-purpose ethylene-propylene-diene terpolymer with premium performance abilities. NORDEL is made by Du Pont, fabricated into finished goods or component parts by rubber companies, and used by manufacturers of automobiles, appliances, electrical equipment and other industrial and consumer products. Areas of application for NORDEL are discussed in the next section of this report.

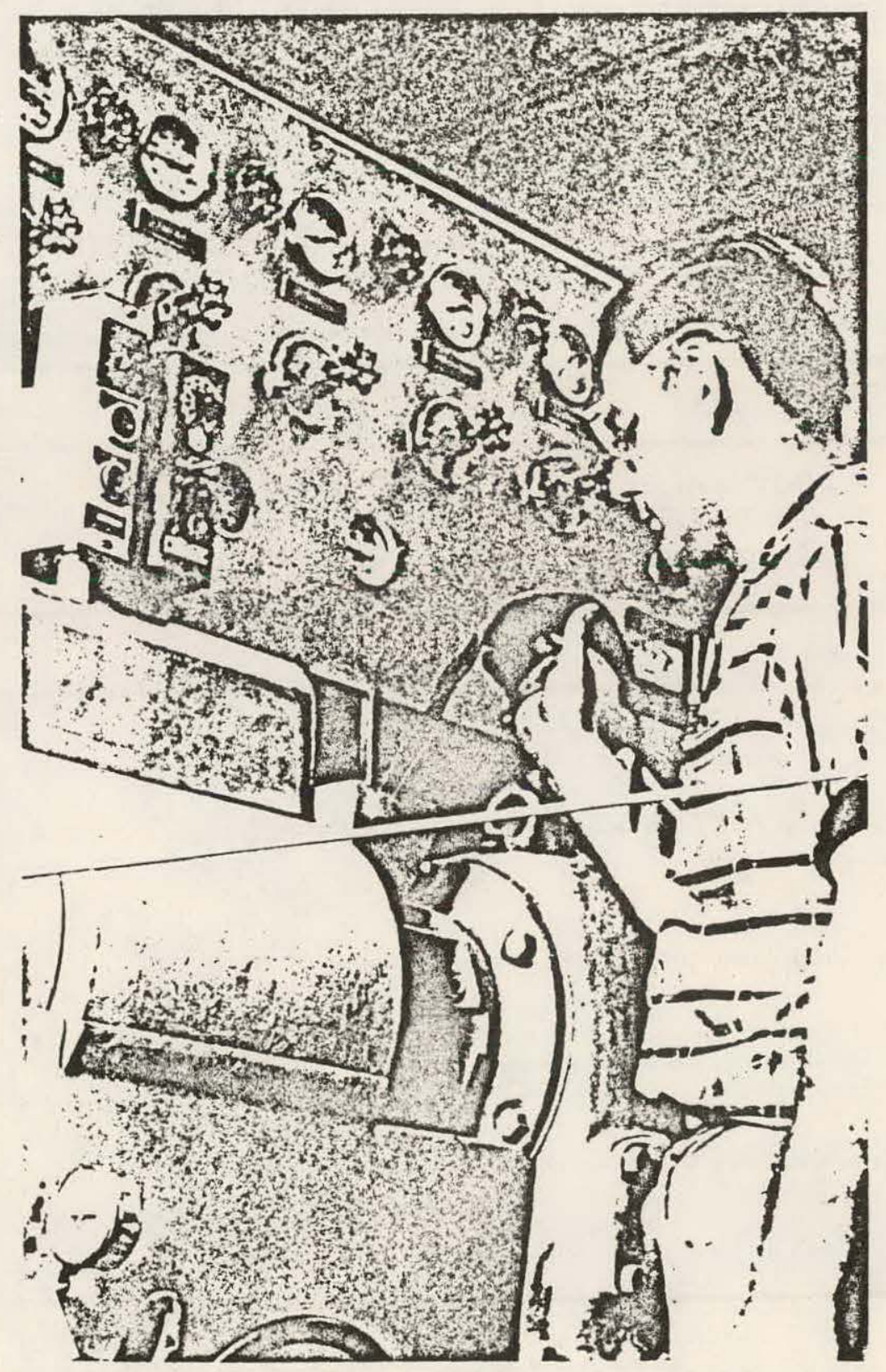

Extrusion of wire insulation is typical of the conventional rubber-industry manufacturing processes in which NORDEL is used. No specialized fabrication or curing techniques are needed. 


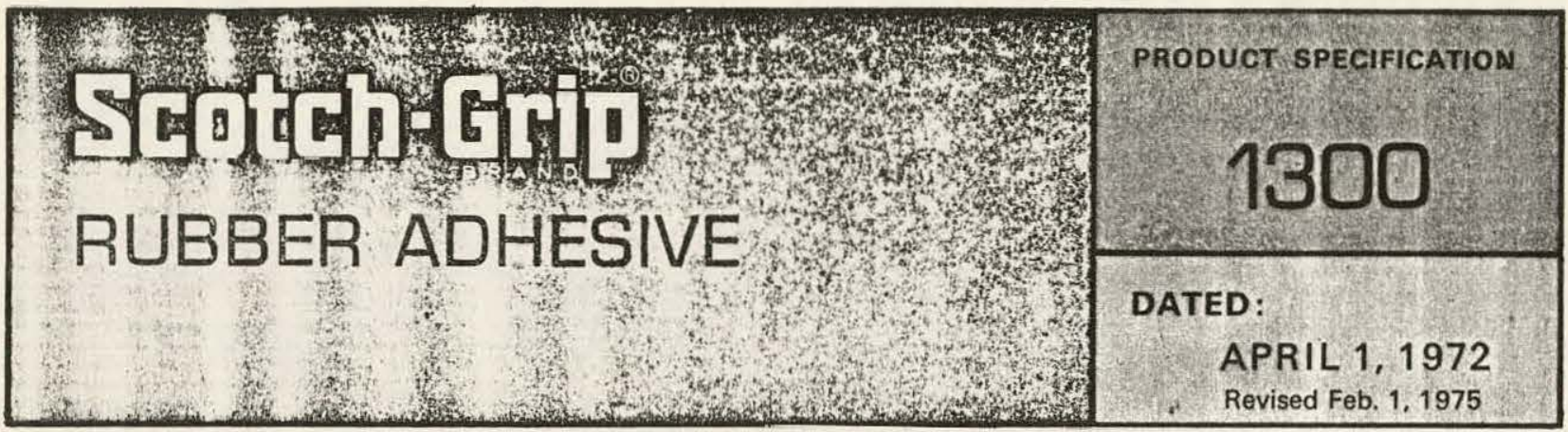

DESCRIPTION:

- A fast drying adhesive that develops high immediate strength. Has excellent heat resistance.

- Bonds Neoprene, reclaim, SB-R and Butyl rubber to metal, wood, most plastics and many other substrates.

PHYSICAL PROPERTIES

\begin{tabular}{|c|c|c|}
\hline $\begin{array}{c}\text { BASE } \\
\text { Synthetic Elastomer }\end{array}$ & $\begin{array}{c}\text { NET WEIGHT } \\
7.3 \pm .2 \mathrm{lbs} . / \mathrm{gal} .\end{array}$ & $\begin{array}{c}\text { CONSISTENCY } \\
\text { Medium Syrup }\end{array}$ \\
\hline $\begin{array}{c}\text { SOLVENT } \\
\text { Petroleum Distillate, MEK }\end{array}$ & $\begin{array}{c}\text { FLASH POINT } \\
-14^{\circ} \mathrm{F} .\end{array}$ & $\begin{array}{c}\text { VISCOSITY (APPROX.) } \\
2400 \mathrm{cps}\end{array}$ \\
\hline COLOR & $\begin{array}{c}\text { SOLIDS CONTENT } \\
\text { (APPROX.) } \\
\text { Yellow }\end{array}$ & $\begin{array}{c}\text { BROOKFIELD VISCOSIMETER } \\
\text { RVF.\#4 sp. (il } 20 \mathrm{rpm}\end{array}$ \\
\hline
\end{tabular}

APPLICATION CHARACTERISTICS

\begin{tabular}{|c|c|c|}
\hline $\begin{array}{c}\text { METHOD } \\
\text { Brush or Flow }\end{array}$ & $\begin{array}{c}\text { COVERAGE } \\
(1 \mathrm{MIL} \text { DRY FILM }) \\
396 \text { sq. ft./gal. }\end{array}$ & $\begin{array}{c}\text { BONDING RANGE } \\
\text { (10 Mil Wet Film, 2 Surfaces }) \\
\text { Up to 12 Minutes }\end{array}$ \\
\hline
\end{tabular}

\section{EQUIPMENT SUGGESTIONS}

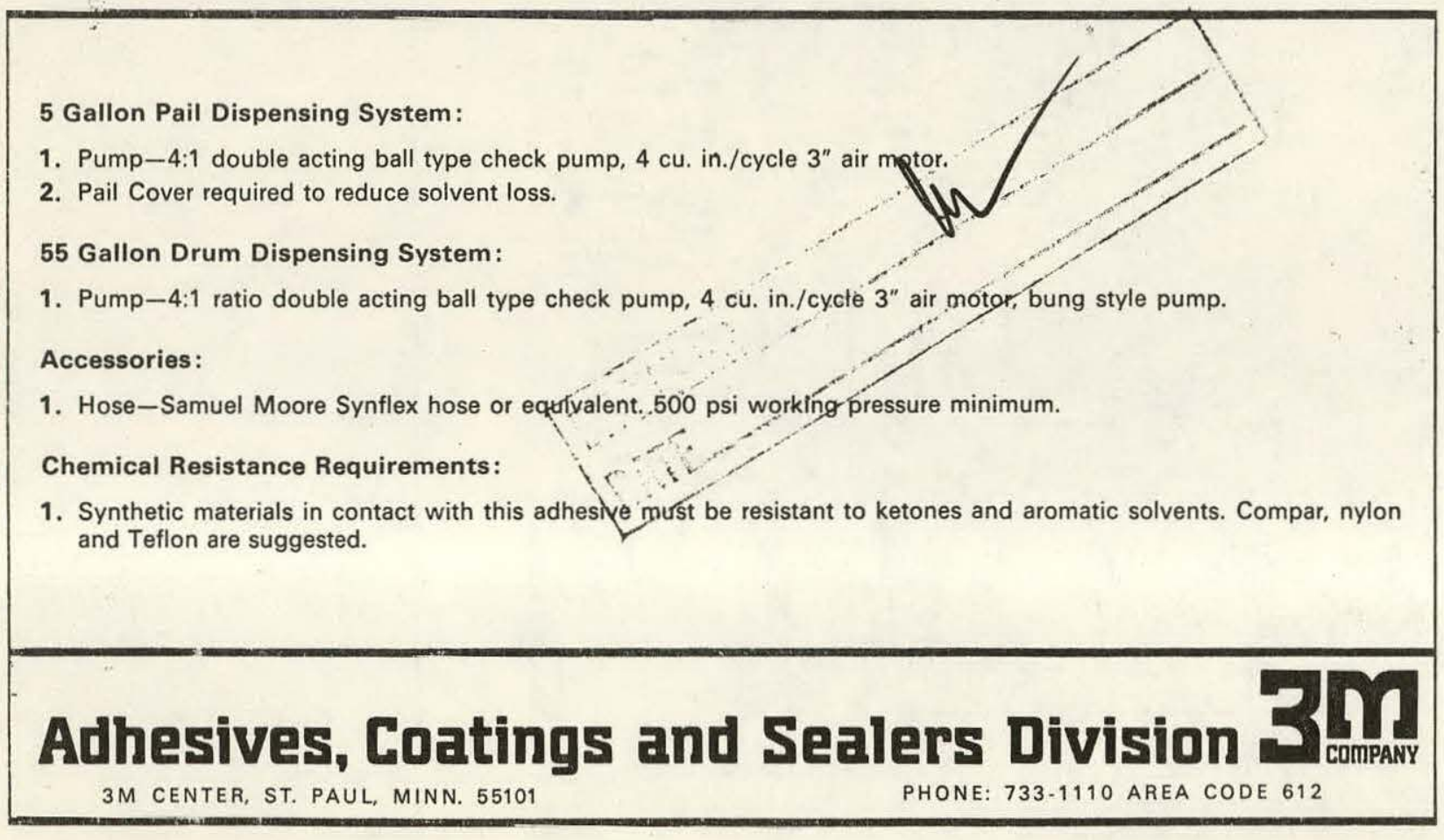




\begin{tabular}{|c|c|c|c|c|}
\hline \multicolumn{3}{|c|}{$\begin{array}{l}180^{\circ} \text { PEEL STRENGTH } \\
\text { Canvas/Steel }\end{array}$} & \multicolumn{2}{|c|}{$\begin{array}{c}\text { OVERLAP SHEAR STRENGTH } \\
1 /{ }^{\prime \prime} \text { Birch } / \% " \text { Birch }\end{array}$} \\
\hline Time (1) $75^{\circ} \mathrm{F}$. & Test Temp. & Value (lbs./in. width) & Test Temp. & Value (psi) \\
\hline $\begin{array}{l}1 \text { day } \\
3 \text { days } \\
5 \text { days } \\
7 \text { days } \\
2 \text { wk. } \\
3 \text { wk. } \\
\text { after } 3 \text { wk. } \\
\text { after } 3 \text { wk. } \\
\text { after } 3 \text { wk. }\end{array}$ & $\begin{array}{c}75^{\circ} \mathrm{F} \\
75^{\circ} \mathrm{F} \\
75^{\circ} \mathrm{F} \\
75^{\circ} \mathrm{F} \\
75^{\circ} \mathrm{F} \\
75^{\circ} \mathrm{F} \\
-30^{\circ} \mathrm{F} \\
150^{\circ} \mathrm{F} \\
180^{\circ} \mathrm{F}\end{array}$ & $\begin{array}{l}18 \\
48 \\
51 \\
52 \\
30 \\
20 \\
49 \\
32.5 \\
26\end{array}$ & $\begin{array}{r}-30^{\circ} \mathrm{F} \\
75^{\circ} \mathrm{F} \\
150^{\circ} \mathrm{F} \\
180^{\circ} \mathrm{F} \\
200^{\circ} \mathrm{F} \\
225^{\circ} \mathrm{F}\end{array}$ & $\begin{array}{r}343 \\
549 \\
195 \\
136 \\
85 \\
. \quad 85\end{array}$ \\
\hline
\end{tabular}

All test data reported represent the typical average obtained using the testing procedures described. The typical range, where applicable, represents the range in average values that can be expected on multiple lots of material.

The data reported portray typical product performance and are not intended to be used for specification limits. Establishment of specification limits, certification requirements, and the test procedures involved must be reviewed and approved by $3 \mathrm{M}$.

\section{DIRECTIONS FOR USE}

SURFACE PREPARATION : Surfaces must be clean, dry and dust free. Wiping with Scotch-Grip Brand Solvent No. $3^{\circ}$ will aid in removing oil and dirt. For best results, temperature of adhesive and surfaces should be at least $65^{\circ} \mathrm{F}$. If stored below $30^{\circ} \mathrm{F}$., warm up, followed by thorough agitation may be required.

APPLICATION : Stir well before using. Brush or flow a thin, uniform coat of adhesive on each surface. Allow adhesive to dry until tacky but so that it does not transfer to your knuckle (maximum dry time about 4 minutes). Assemble materials with sufficient pressure to insure contact.

DRYING TIME: Bonded parts have high immediate strength to facilitate normal handling.

CLEAN-UP: Excess adhesive may be removed with Methyl Ethyl Ketone, Toluol, or Scotch-Grip Solvent No. 2 or 3. REACTIVATION: Greater immediate strength may be obtained by solvent reactivation. To solvent reactivate, coat both surfaces with adhesive. Allow to dry tack-free. Lightly wipe one surface with Methyl Ethyl Ketone." Complete bond within 30 seconds.

-When using solvents for reactivation or clean-up, it is essential that proper precautionary measures for handling such materials be observed.

\section{STORAGE AND HANDLING}

Store product at $60-80^{\circ} \mathrm{F}$. for maximum storage life. Higher temperatures reduce normal storage life. Lower temperatures cause increased viscosity of a temporary nature. Rotate stock on a "first in-first out" basis. Upon request, your 3M Adhesives, Coatings and Sealers Sales Representative will be pleased to advise you of the anticipated shelf life of this product under the storage conditions in your plant.

Clean-up can be accomplished with Methyl Ethyl Ketone, Toluol or Scotch-Grip Brand Solvent No. 2 or 3. When using solvents for clean-up, it is essential that proper precautionary measures for handing such materials be observed.

ICC SHIPPING CLASSIFICATION : Adhesive Cements, NOI. Red label required.

\section{DANGER! EXTREMELY FLAMMABLE}

Keep product and its vapors away from heat, sparks and open flames. The vapors given off from this adhesive will burn. Contains petroleum distillate. Use only in well ventilated areas with enough air movement to remove vapors and prevent vapor buildup. Avoid breathing vapors. Avoid eye contact and prolonged or repeated contact with skin. Suggested first aid for eye contact; immediately flush with plenty of water and obtain medical attention. Keep out of reach of children. Keep container closed when not in use.

\section{IMPORTANT NOTICE TO PURCHASER}

All statements, technical information and recommendations contained herein are based on tests we believe to be reliable, but the accuracy or completeness thereof is not guaranteed, and the following is made in lieu of all warranties, express or implied:

Seller's and manufacturer's only obligation shall be to replace such quantity of the product proved to be defective. Neither seller nor manufacturer shall be liable for any injury, loss or damage, direct or consequential, arising out of the use of or the inability to use the product. Before using, user shall determine the suitability of the product for his intended use, and user assumes all risk and liability whatsoever in connection therewith.

No statement or recommendation not contained herein shall have any force.or effect unless in an agreement signed by officers of seller and manufacturer. 


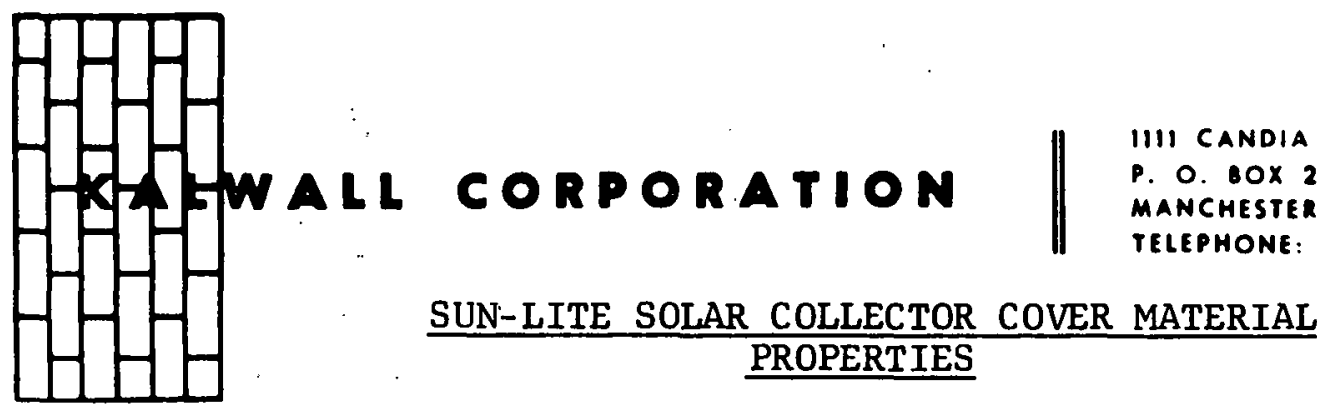

FEATURES :

* Solar Properties as Good as or Better Than Glass ** Superior Impact and Shatter Resistance

**Easy Maintenance and Repair

**Economical (Low Initial and Life Cycle Costs)

** Thermal Expansion Matches Aluminum
**UV and Weather Resistant

** Inert to Chemical Atmosphere **Large Sheet Size Eliminate Joints **Easily Cut with Hand Tools **Light Weight, Yet Rigid

\section{AVERAGE PHYSICAL PROPERTIES}

Solar Energy Transmittance Estimated Solar Lifetime (1) Thermal Senstitivity

(2)

Heat Transmittance Index of Refraction Tensile Strength Flexural Strength ral Modulus

She:" Strength Izod Impact Water Absorption Thermal Expansion Thermal Conductivity Specific Heat Specific Gravity We ight Thickness Sheet Size
METHOD . UNITS

E 424 Method B

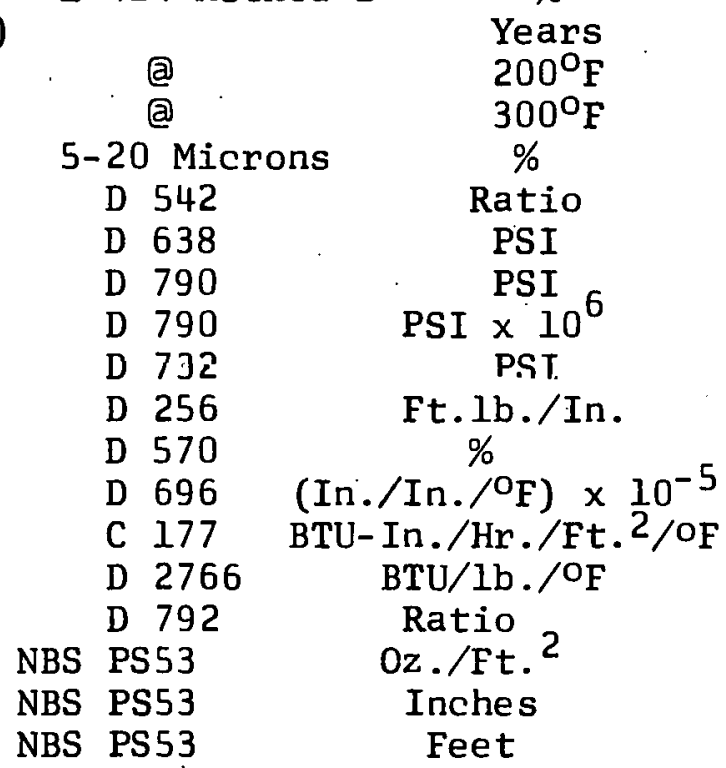

\begin{tabular}{|c|c|}
\hline $\begin{array}{l}\text { SUN-LITE } \\
\text { REGULAR }\end{array}$ & $\begin{array}{r}\text { SUN-LITE } \\
\text { PREMIUM }\end{array}$ \\
\hline $85 \%-90 \%$ & $85 \%-90 \%$ \\
\hline $\begin{array}{c}7 \\
\text { Excellent }\end{array}$ & $\begin{array}{c}20 \\
\text { Excellent }\end{array}$ \\
\hline Poor & Good \\
\hline $10 \%$ & $10 \%$ \\
\hline 1.54 & 1.54 \\
\hline 16,000 & 16,000 \\
\hline 24,500 & 24,500 \\
\hline 14,000 & 14,000 \\
\hline 18 & 18 \\
\hline $0.20-0.33$ & $0.20-0.33$ \\
\hline 1.4 & 1.4 \\
\hline .87 & .87 \\
\hline .35 & .35 \\
\hline 1.4 & 1.4 \\
\hline $2.8-4.7$ & $2.8-4.7$ \\
\hline 025 or .040 & .025 or .040 \\
\hline
\end{tabular}

NOTE:

1. Tests indicate that Regular Sun-lite will lose about 10\% solar transmission in 7 years while Sun-lite Premium should have no appreciable loss for 20 years (estimate).

2. Sun-lite products are generally not affected by higher temperatures. The resins will not melt or cold flow since they are thermosetting and reinforced with glass fibers. The ignition temperature exceeds 9000F. However, continuous exposure at temperatures exceeding $2000 \mathrm{~F}$ will cause a slight amber color to appear which will have only a modest effect (5\%) on Sun-lite's properties. Continuous exposure at $300^{\circ} \mathrm{F}$, causes about a $10 \%$ decline in solar transmittance in Sun-lite Premium and a more severe decline in Sun-lite Regular.

3. Special Sun-lites are now under development to meet additional fire code requirements and for moist heat applications. Sun-lite Regular and Premium are not recommended for moist heat applications.

The above information is presented in good faith, but no warranty is expressed o implied.

Form: SP-33 


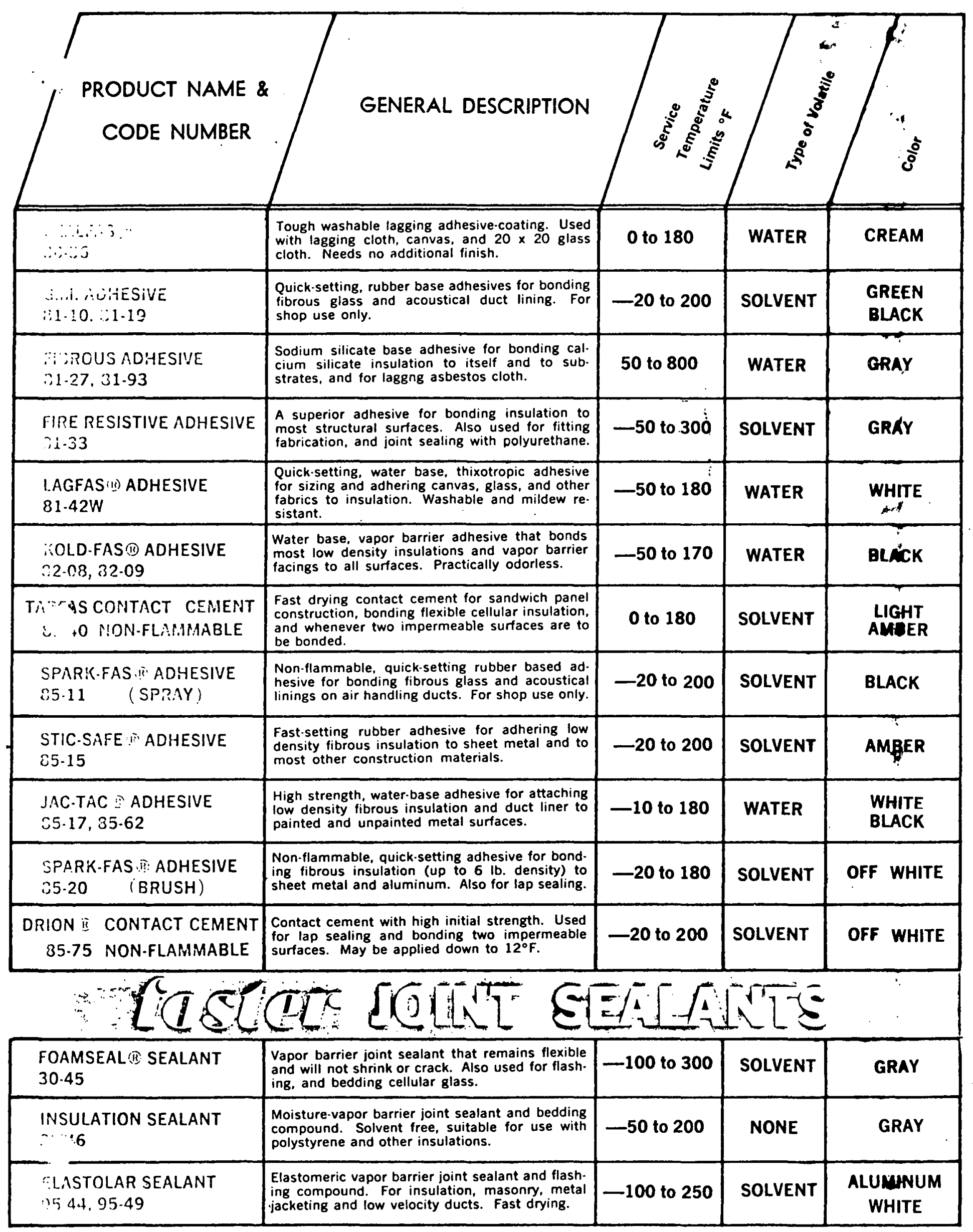




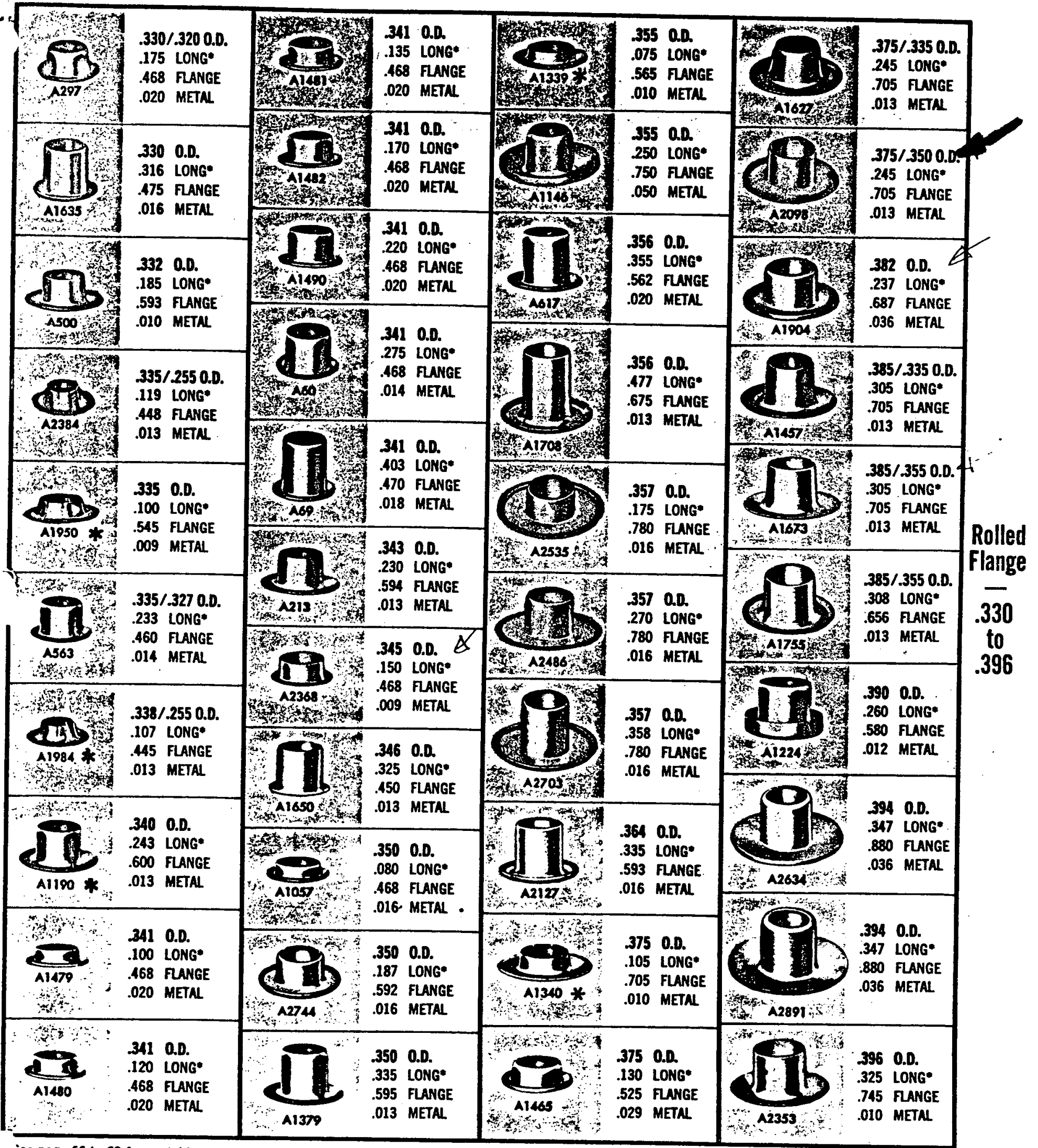

See page 66 to 69 for matching telescoping eyelet or neck washer.

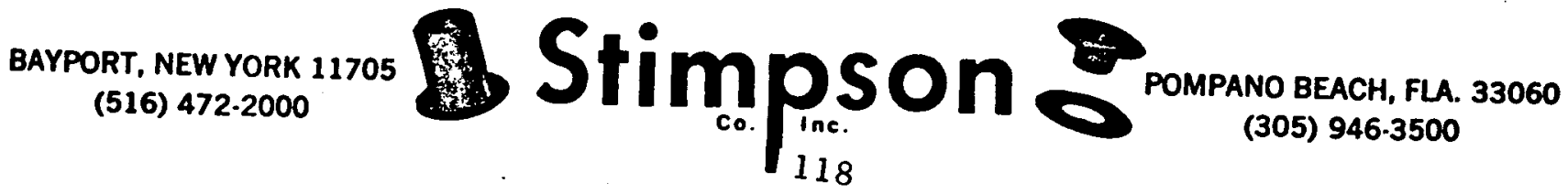




\section{K \& K CHEMICALS, INC.}

IO ROXBORO ROAD - LAWRENCEVILLE, N. J. 08648

TELEPHONE: (609) 396-0061

\section{TABLE I}

\section{Typical Propertics}

\begin{tabular}{|c|c|c|c|}
\hline & $\begin{array}{l}\text { (mlxed } 1: 1 \\
\text { by welght) }\end{array}$ & Component $305-1$ & Component $: 05-2$ \\
\hline Color & Blue & Clear Amber & Blue \\
\hline Consistency & Medium - Heavy Syrup & Medium Syrup & Heavy Syrup \\
\hline Viscosity $\left(77^{\circ} \mathrm{F}\right)\left(25^{\circ} \mathrm{C}\right)$ & - & $10,000-18.000$ & $20,000-45,000 \mathrm{cps}$ \\
\hline & & $\left(10-18 N S / M^{2}\right)$ & $\left(20-45 N \cdot S / M^{2}\right.$ \\
\hline Solids Content & 97 to 99 Percent & 99 to 100 percent & 96 to 99 Pércent \\
\hline Specịtic Gravity & 1.06 & $1.14 \cdot 1 .: 8$ & 0.97 \\
\hline $\begin{array}{c}\text { Weight (Lbs./Gal.) } \\
\qquad\left(\mathrm{Kg} / \mathrm{M}^{3}\right)\end{array}$ & $\begin{array}{l}8.8-8.9 \\
1054-1066\end{array}$ & $\begin{array}{l}9.6-9.8 \\
1150-1174\end{array}$ & $\begin{array}{l}7.9-8.1 \\
947-971\end{array}$ \\
\hline Flash Point $\because$ & Non-flammable & Non-flammable : & Non-flammable \\
\hline Shelf Life & - & More than 1 year & More than 1 year \\
\hline $\begin{array}{l}\text { Working Life } \\
\text { (1 lb. batch? }\end{array}$ & $11 / 2$ to 2 hours & $\longrightarrow$ & · \\
\hline
\end{tabular}

Mixing Ratjo

(By Weight)

Hardness (Shore D)

Rubber to Metal

Peel Strength (Lbs./In. at $77^{\circ} \mathrm{F}$.) $\left(25^{\circ} \mathrm{C}\right)$

SBR Elastomer to Steel

Neoprene to Steel

Metal to Metal

Shear Strength (psi at $\left.77^{\circ} \mathrm{F}\right)\left(25^{\circ} \mathrm{C}\right)$

Aluminum to Aluminum

Steel to Steel

Gardner Labs

Impact Strength

160 inch pounds at $77^{\circ} \mathrm{F} .\left(25^{\circ} \mathrm{J}.\right)$. Fail

160 inch pounds at $-22^{\circ} \mathrm{F} .\left(-29^{\circ} \mathrm{C}\right.$. $)$

\section{TABLE II \\ Test Results}

Alternate A

Ratio A

2 parts 305-1

1 part 305-2

87

\section{General Purpose \\ Ratio.}

1 part 305-1

1 part 3 )5-2

85

$188(3 c .9 \mathrm{~N} / \mathrm{mm})$

$99(17.3 \mathrm{~N} / \mathrm{mm})$

$107(18.7 \mathrm{~N} / \mathrm{mm})$

$2610(17995 \mathrm{~N} / \mathrm{mm})$

$2720(18753 \mathrm{~N} / \mathrm{mm})$

2366 (1E $313 \mathrm{~N} / \mathrm{mm}$ )

$1946(13417 \mathrm{~N} / \mathrm{mm})$
Ailternate Ratio B

1 part 305-?

2 parts 305-2

57

60 (10.5^imm)

93 (16.3Nimm)
$1932(1332 \cdot \mathrm{N} / \mathrm{mm})$

$1616(1114: \cdot \mathrm{v} / \mathrm{mm})$ 


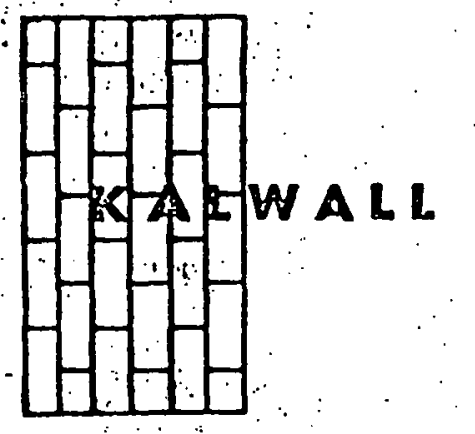

\section{conponarion: |}

IIII CANDIA ROAD

P. O. BOX. 237

MANCHESTER. N. H. O3105

TELEPHONE: A/C $603627-3861$

KAL - LAC

Kalonacis

Kal-lacils a transparent air drying coating material for fiberglass reinforced polyester mateíiol. Kal-lac will restore the original luster and finish of such material which may have become dulled or roughened by prolonged exposure to the weather.

\section{?}

Surface Preparation:

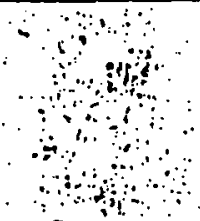

Application:

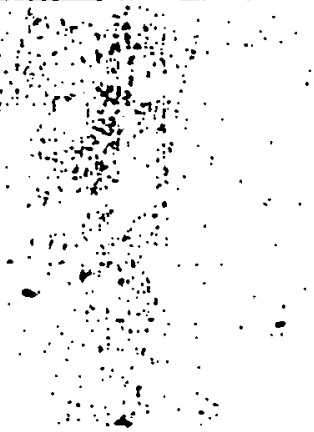

Drving Time:

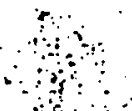

- Equipment Cleanup:

\section{Precautions:}

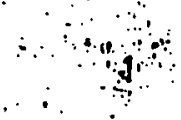

Cleaning Kal-lac Coated Panels

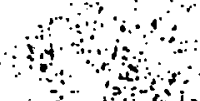

Using general grade, verý fine type a Scotch Brite, rub the exposed surface moderately, until the free expcsed fiber's ancl embedcled dirt are removed. Wet down the panel with clear water to rinse off loose surface [iber's and dirt. Allow to dry thoroughly.

Use Kal-lac as supplied without dilution. Application by roller coater is an inexpensive and efficient method. The core of the roller should be impregnated cardboard. Plastic cobes will soften in the Kal-lac. A minimum dried thickness of l.0_mil is recomnended. 'It will probably be necessary to apply two liberal coats; and. possibly a third coat to the more severly weathered sheets but im amy.-cast, wourh Kal-lac must be applied to give a cylossy finish to the entire surface when dry. Allow adequate drying time between coats.

Kal-lac will dry to tack-free condition within 5-10 millutes. Maximum harclness is attained $a=10$ to 15 hours at room teniperature.

Me thylethyl Ketone (NEK), Acetone, or lacquer thinner. will satisfactorily clean up the application equipment.

Kal-lac contains flammable liquids and stould be kept away Erom open flames. Provide gadequate ventilation. Prolonged breathinic of vapors should be avoided.

Commercially availabie detergents are satisfactory. Do not use Ketone badsed solvents, gasoline, lacquer thinner, or other petroleuim befsed materials.

The information contained herein is presented ingood faith No warranty pir guarantee expressed or implied is male regarding the performance or stability. of the product, since the manner of use and conditions of storage and handling arè beyond our control. 


\title{
CENTER FOR INDUSTRIAL AND INSTITUTIONAL DEVELOPMENT
}

\author{
TOXICITY OF SMOKE FRO I BUT'NINC: \\ KAL-LITE PANE .S
}

\author{
for \\ Kalwall Corporation \\ 88 Pine Street \\ Manchester, N. I. \\ 03101
}

\author{
By \\ Laurance E. Webber, P.'E. \\ Research Profes ior \\ June 19, 1973 \\ Kingsbury Hall \\ UNIVERSITY OF NEW HAMPSHIRE \\ Durham, New Hampshire 03824
}




\section{CENTER for [INDUSTRIAL and $]$ INSTITUTION $1 L$ DEV ELOPMENT}

Kingsbury Hall University of New Hampshire

Durham, New Hampshire 03824

(603) 862-1354

TOXICITY OF SMOKE EROM BURNING .AL-LITE PANEIS

\section{PURPOSE}

To conduct a toxicity test of the products of combustion of kallite as manufactured by Kalwall Corporation, Manchester, New Hampshire.

Since there is no standard test for measuring the toxicity of smoke from burning plastics, we followed a test which we believe is indicative of the hazard to be expected from burning fiberglass reinforced polyester (FPP) plastic. Obviously, the carbon monoxide usually generated by limited-oxygen burning can be lethal, and the smoke can displace the air (oxygen) from the area, but in this test we were concerned with the toxic effects of breathing the smoke generated by the burning FRP.

\section{PROCEDURE}

Six female albino rats of the $C D$ strain (Sprague-Dolly descendants) aged 65 days and weighing between 150 and 200 grams were the subjects of the experiment. The rats were placed in a clear plastic cylinder 14" in diemeter and 8" high. The cylinder was covered except for three 1/4" holes in the top. The bottom consisted of 1/4" mesh hardware cloth. Pieces of the plastic sheets were burned about 2 feet away from the test cylinder and the smoke was led into the chamber through a 3" galvanized pipe. (This was done to prevent and discomfort to the rats that might have resulted from hot wire in contact with their feet.) The density of smoke was quickly built up to a point at which the rats could only be hazily seen and the other side of the chrmber could not be seen. The solrce of smoke was cut off at this point and no more was added. The 
atmosphere remained hazy for over one-half an hour.

six other female albino rats of the same strair and ancestry, and of the same 65 days of age, were similarly subjected to smoke generated by burning a mixture of paper and wood.

\section{CONCLUSION}

The rats exposed to the FRP smoke showed no signs of distress and/or abnormality and were returned to their lab cages 1 hour after the start of the smoke exposure. When examined 120 hours later, none of the rats exhibited any signs of reaction to their e:posure to the smoke from this burning FRP.

The rats exposed to the combination paper and wood smoke likewise showed no signs of distress and/or abnormaility and were returned to their lab cages 1 hour after the start of the smoke exposure. When examined 72 hours later, none of the rats exhibited any signs of reaction to their exposure to the smoke from this burning wood and paper.

In these tests; the smoke from the $F$ FP caused no different reaction in the rats than was caused by the smoke from wood and paper.

Respectfully submitted,

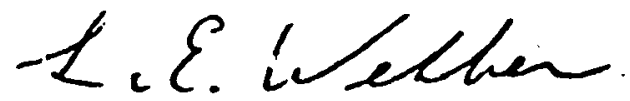

Laurance $E$. Webber, P.E. Associate Director Research Professor

University of New Hampshixe

Lab Peport No. $\mathrm{K}-101$

June 19, 1973

LEW : I 


\section{the fire-resistant properties of}

ry

\section{KALWALL ${ }^{\circledR}$ TRANSLUCENT WALLS}

Translucent Kalwall's sandwich construcition - two face sheets of fiberglass bonded to an alu.ninumingrid core - presents an outstanding practical firc barrier. Under direct exposure to flame, Kalwall will usually prevent the spread of fire to other parts of a building. Kalwall cannot shatter or otherwise endanger persons or property, and Kalwall's faces contribute a mini-

\section{4-hour fire test ....}

An independent laboratory tested samples of window glass and standard Kalwall which were individually mounted in the front opening of a chamber cnclosing an oil burner. A fire was maintained at a temperature of approximately $1,200^{\circ} \mathrm{F}$. While the glass samples cracked and burst out of the frame in less than live minutes, the fire had not burned through the outside of Kalwall after a perind exceeding four hours:

The table at right points out that the exterior face of the Kalwall sample never dttained a sufficient temperature to ignite." This is a direct result of Kalwall's sandwich construction. The plastic resin mum amount of fuel to a fire.

A summary of the results of exte:lsive testing by independent laboratories and by kalwall Corporation is presented below. as a guide to the fireresistant properties of Kalwall. in the face exposed to the flame was consumed; however, the fircproof fiberglass mat remained bonded to the grid, thus preventing the flame from reaching the exterior face.

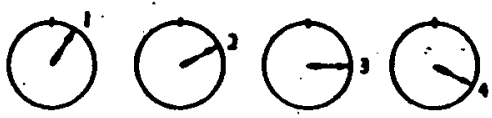

\begin{tabular}{|c|c|c|c|c|}
\hline & ine & In & In & I l mown \\
\hline 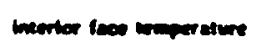 & $1000 \%$ & $\infty 000 \%$ & $000 \%$ & $0 \times 0 \%$ \\
\hline 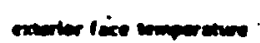 & als: & $m \cdot p$ & $405 \cdot F$ & $\cos ^{\circ} 1$ \\
\hline
\end{tabular}

\section{high ignition temperatures ....}

The temperature required 10 ignite the resin in Kalwall's face material is $650^{\circ} \mathrm{F}$, when tested in accordance to ASTMD 1929*. This significantly higher than that for many malcrials commonly found in . huilding. The graph shows thall Kalwall's ignition temperature is about $100 \%$ gredter than that of worsd, common plastics, curtain material and paper.

- Other Iests shuw I'mins as highl us 8.51PF:

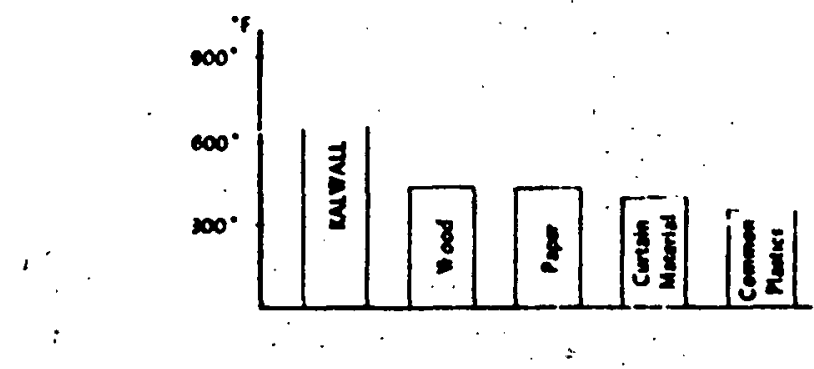

including 25 are possible. Standard pancls meet most building codes and are normally acceptable. Consult Technical Services Department if assistance is required. 
The fiece sheels of Kalwall pancels have a herri iale of less than ll: inches per minute hy ASIN D 6.35. This is a test designed to medsure the response of plastics to fire under laboratory conclitions and concel ution with flanmabilits Inder actual use con. ditions is not nece sarily implied. Hlowever, many ndtiosidil and model building codes use a burn rille ol less thatn $2 \frac{1}{2}$ inch ser minute by this test as minimum stindlurd for approved plastics.

\section{class "a" burning brand test....}

ASIM I: IOS is a test designed fo mestsule the lat.

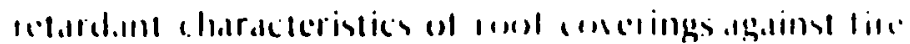
inginaling outside the building ent which the! .110 installed. Insulated Kalwall palleds will pass the aquitcoment of a Closs " $\wedge$ " Burmun: Brind.

1 burning wouden brand $12 . " 12 " 12.3 / 8^{\prime \prime}$ w.ds

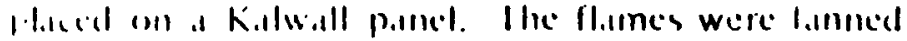
Iv. I?mph "ind. The brand vas allowed to burn umbl it complests burned sut.

Although the under side of the Katwall pancls umohid, ne ll.tmes or drippings were observed on lhe under side of the Kalwall panel.

\section{7\% non.combustible materials .. shatterproof}

In the case of a fire, the plistic resin in Kalwall's faces will contribute very little luel . . in fact. hardly more than several coats of paint on a masunry will, if the draperies commonly found behind windows. And unlike common gloring materịals,

\section{a case history....}

The enclosed mall of a shopping center lunder construction in London. Ontarion, Canada feollured translucent Kalwall in a clerestory upplicillion. During the final stages of construction, a welder's spark caused a lire in the build-up asphalt rout adjacent to the Kalwall. Spreading rapidly across the roof the flames theiltened in crealle exlensive dannoge withill the building. But the Kalu all colltained the fire, pre-

Jenting it lion nentering the huildints.

For complete nformation on Kalwall Translucent Walls, see our catalog in Sweet's Architectural File
K.llwall will not shatter or explnde from its frame .. does not present a possible has rd to nearby persons. We do lavor the use of sprinklers for tire protection whenever practical.

Both the irchites: and contractor attribute the rilatively li " loss is Kalwall's fire-resistant prope lies. The architecl states: "It is estimated th t dumugr' (o) 'd cusily have anuminted to $\$ 1,000,000$, Kulwall hal not hea"l used in the ubove mentioned "urcts.". I ess than 7\% of this amount was actually Iosit.

"(Nomle and address of building, architect and con(racior ivailable on request). 
One of the weathering factors that should be considered for mainten$r$ ance of long term performance is surface erosion. surface erosion is the actual physical wearing away and oxidation of the surface. The result is exposed fibers on the surface sometimes called "fiber bloom". In order to measure the amount of surface erosion, measurements were taken with a Clevite 1200 Surfanalyzer. Both average roughness and peak-to-valley roughness were measured.

First consider average surface roughness (the average magnitude of all surface irregularities reported in microinches or $1 / 1,000,000$ of an inch). The surface erosion for material \#l is not noticeable for the first three years of outdoor weathering in South Florida. However, at the end of four years, some surface roughness was noticeable, and after five years, there was about 55 microinches of average erosion. A standard grade of fiberglass can have more than 105 microinches of average erosion after only (two years of South Florida exposure. (Fig. 6). In order to halt this kind of surface erosion, a proprietary high temperature coating manufactured by Kalwall Corporation called Kalwall Weatherable Surface can be applied. After five years of weathering exposure, only 14 microinches (hardly noticeable to the human eye) of average erosion was measured on material \#1 with this coating. (Material \#IW). A more dramatic measurement is of peak-to-valley roughness. (Fig. 7)

Using peak-to-valley measurements instead of average measurements, material \#1 showed a maximum roughness of approximately 300 microinches change, while the coated sample showed only 100 microinches. Both samples had been weathered for five years in South Florida. A standard grade sheet can have more than 1,000 microinches of erosion after only two years to this same exposure. 

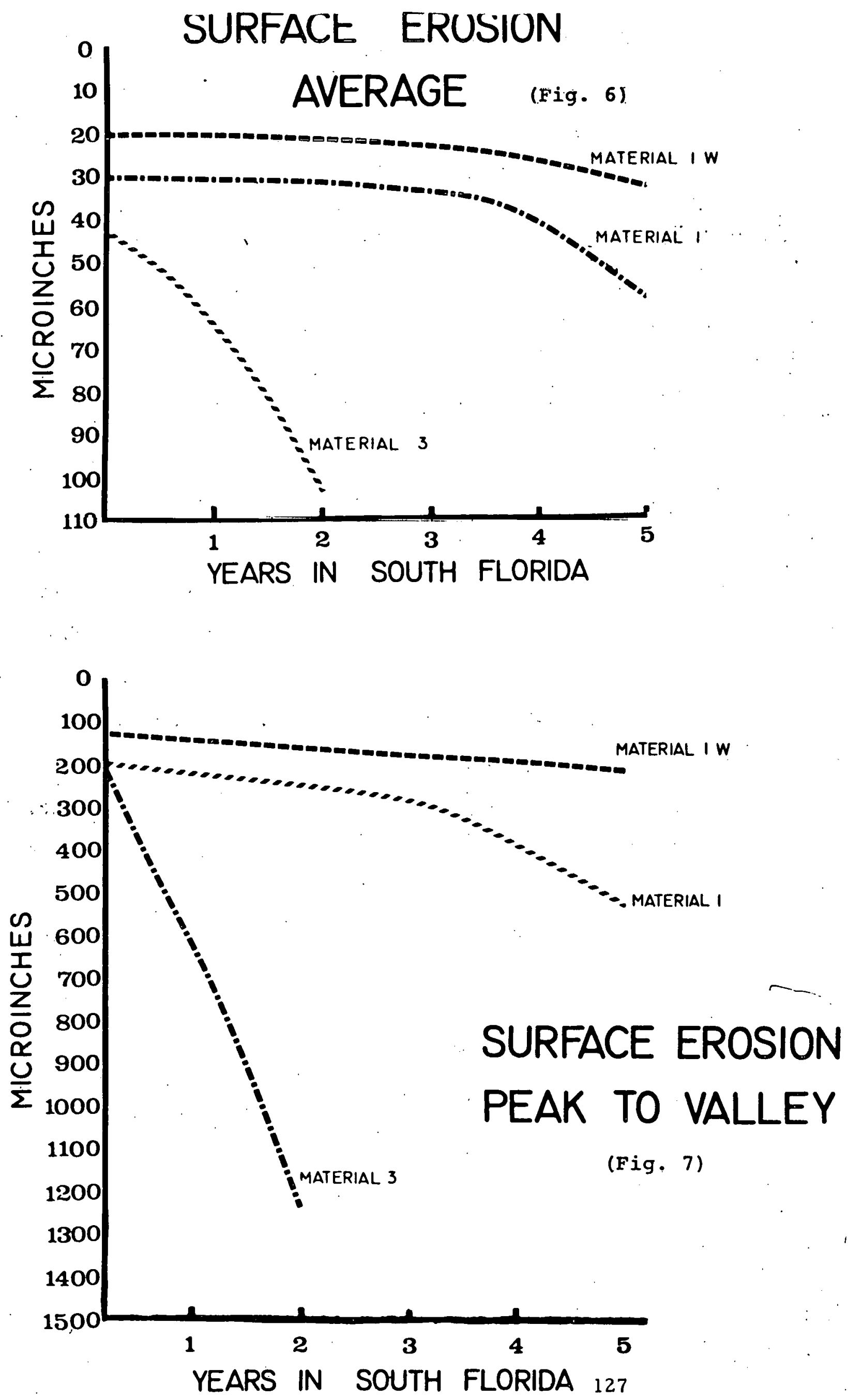


\section{THERMAL DEGRADATION}

In most efficiently operating flat plate collectors the cover temperature will not be above $200^{\circ} \mathrm{F}$; therefore, tests were conducted on samples continuously aged in a $200^{\circ} \mathrm{F}$ oven for 1 year. The drop in solar energy transmission for both material \#1 and material \#2 was approximately equal (about 108). However, the standard grade sheet lost more than 500 solar energy transmission in one year of continuous exposure. (Fig. 4)

Cover plate temperatures higher than $200^{\circ} \mathrm{F}$ may occur during stagnation in collectors with improperly designed venting systems. Stagnation temperatures occur when no fluid (water or air) is flowing through the collector. For example, with $300 \mathrm{BTU} / \mathrm{sq}$. ft. $/ \mathrm{hr}$. insolation, the absorber plate could reach $380^{\circ}$ and the inner cover of a double cover could reach jo if the outside temperature is $60^{\circ}$. For this reason, short term tests were conducted at $300^{\circ} \mathrm{F}$. (Fig. 5)

After 300 hours (equal to $10 \mathrm{hr}$./day for 30 days), material lost only 28 solar energy transmission, while material \#2 lost 48 . Extending the test to 5,000 hours, material \#1 lost approximately 108 solar energy transmission at $300^{\circ} \mathrm{F}$. Material \#2 lost 228 and standard grade material lost 408 under the same conditions. 

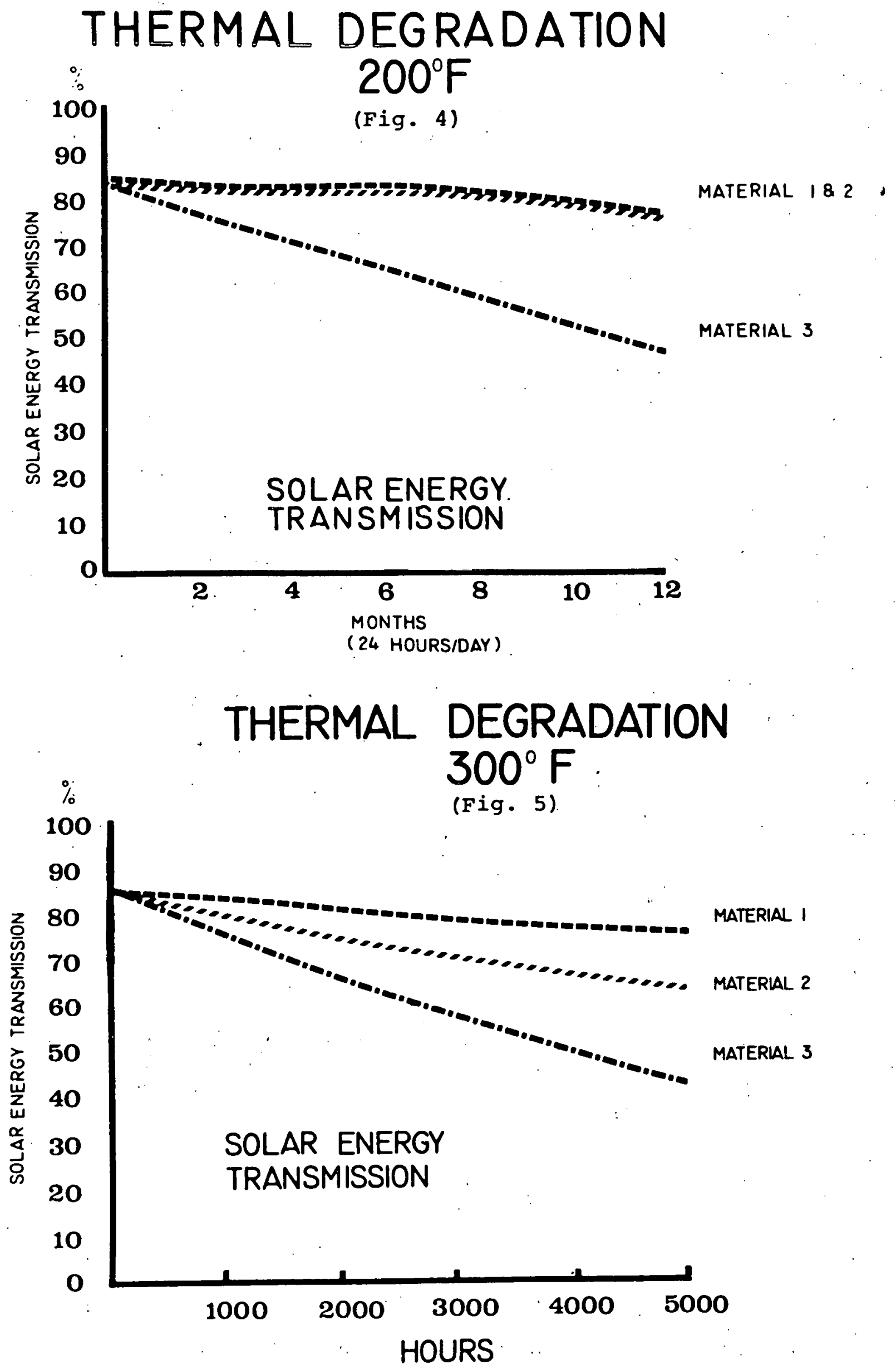
Degradation due to ultraviolet radiation has long been of great confern to those people designing or using products exposed to sunlight. Researchers in the FRP industry have come a long way in retarding ultraviolet degradation. A typical non-light stabilized general purpose polyester can lose more than 158 transmission in just 50 hours of exposure to a sun 1 amp. One of the earliest attempts to improve the UV resistance of polyester was to add ordinary aspirin as a light stabilizing additive. After 50 hours exposure to a sun lamp, a general purpose polyester will only lose 58 transmission if aspirin is added as a light stabilizer.

Obviously, today's researchers have gone much beyond aspirin in the field of light stabilization. Altering the polyester backbone (modifying the glycols and acids which make up polyester), adding acrylic, adding sophisticated light stabilizers, and applying special coatings or films are necessary to produce a quality solar collector cover.

In order to facilitate research into UV degradation, several different weatherometers were developed and are in general use today. The most common are the Fluorescent, Carbon Arc, and Xenon weatherometer. The Fluorescent weatherometer has a high concentration of UV and causes more severe changes than the Carbon Arc or Xenon weatherometer.

Although it is extremely difficult to correlate weatherometer hours to real time outdoors, many researchers use 250-400 weatherometer hours as approximately 1 year actual weathering. $(2,000 \mathrm{hr} .=a p p r o x .5$ yrs. real time.)

Samples were exposed in a fluorescent weatherometer for 2,000 hrs. Color change $(\triangle E)$ and light transmission readings were taken at $500 \mathrm{hr}$. intervals.

COLOR CHANGE - Measurements were taken in accordance with ASTM D 2244 material \#l had a color change of 3.5 after 2,000 hours. Material $\$ 2$ had a color change of 10. Depending on formulation, a standard grade FRP sheet could have a total color change of around 28. (Fig. 2) 
In order to verify the weatherometer results, color change measurements were taken on a sample of material \#l weathered in South Florida =or 5 years. The color change was found to be 4.4 . (A specially coated piece of material \#l had a color change of only $1.1 !)$

South facing exposures in South Florida are considered the most severe natural environment in the United States because of large quantities of sunlight, heat, and moisture.

\section{COLOR CHANGE}

FLUORESCENT WEATHEROMETER

(Fig. 2)

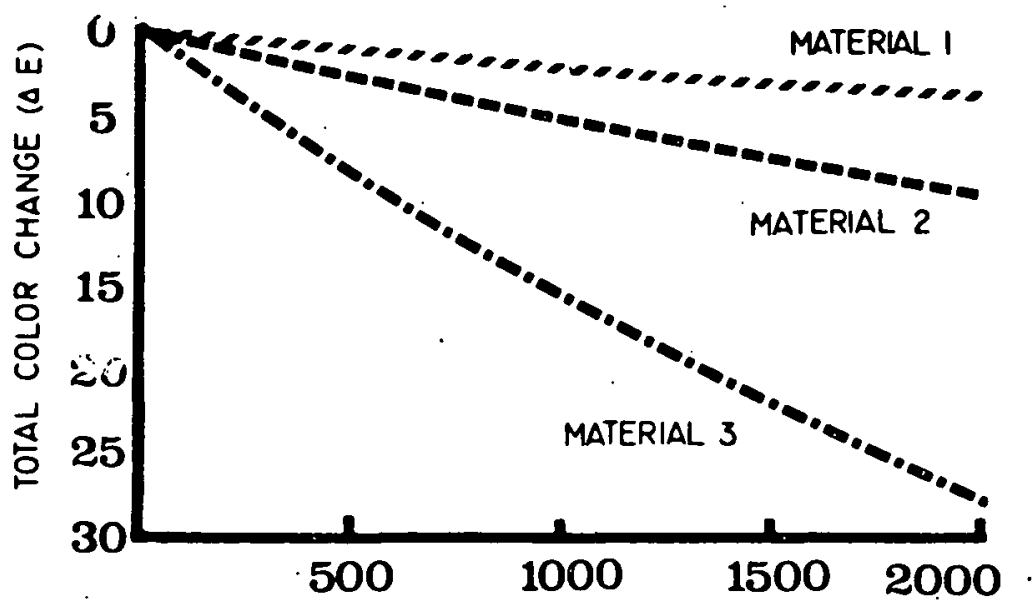

HOURS IN FL.UORESCENT WEATHEROMETER

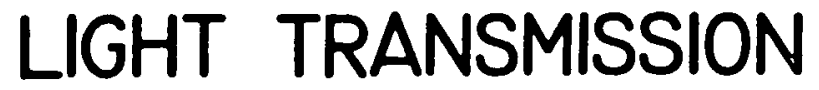
FLUORESCENT WEATHEROMETER $\%$ 100

90

80

70

60

50

40

30

20

10
(Fig. 3)

MATERIAL ।

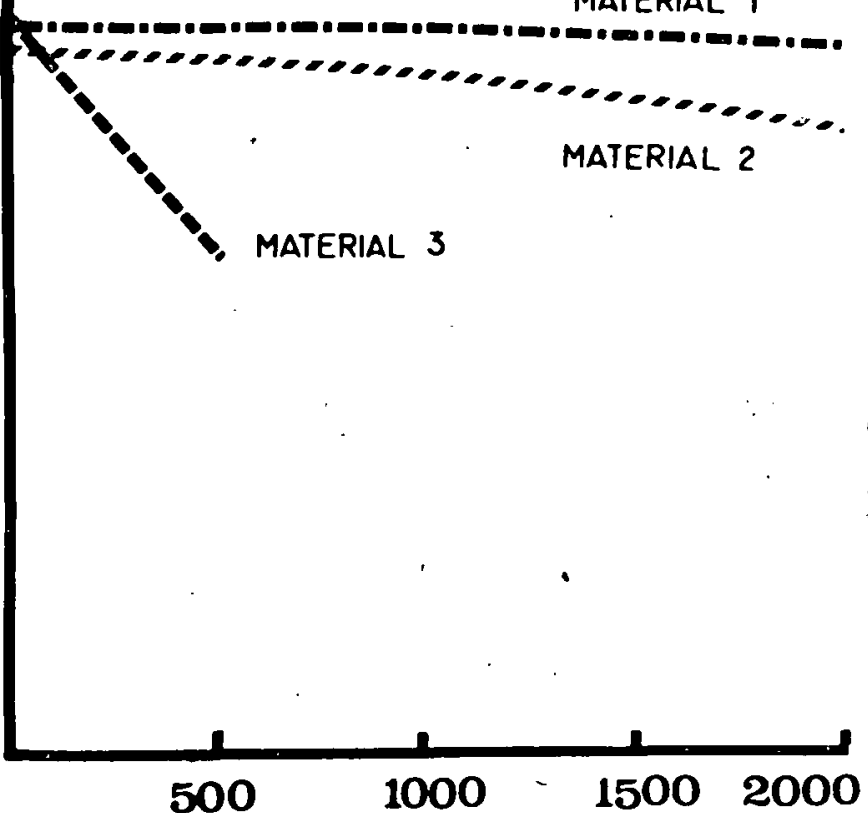

HOURS IN FLUORESCENT WEATHEROMETER

LIGHT TRANSMISSION - Light transmission measurements were taken on the same weatherometer specimens. Material \#l lost oniy 38 light transmission after 2,000 hours, while material \#2 1ost 118. A standard grade fiberglass reinforced polyester can lose up to 208 light transmission in only 500 hours exposure time. (Fig. 3)

It is apparent from the above data that it is extremely important to - onsider the grade of fiberglass reinforced polyester when trying to decriase ultraviolet degradation. Another area of extreme importance for solar collector covers is thermal degradation. 
Embrittlement is often of great concern to people using plastics. Ope of the major reasons fiberglass reinforced polyester is used as a jolar collector cover is its remarkable impact strength and shatter resistance. Unlike glass, which can be easily broken into dangerously sharp pieces, fiberglass reinforced polyester is completely shatter resistant. The best way to measure impact resistance for solar collector covers is to use the falling ball method.

To prove fiberglass does not lose its remarkable impact strength after many years of outdoor exposure, a. 14 year old sample was taken from a building and tested. The control (un-weathered) sample required 25 foot pounds, (6.4 pound steel ball dropped from 4 feet) to cause a rupture of the material while the 14 year old sample required 32 foot pounds (6.4 pounds from 5 feet) to cause rupture. (Fig. 8).

Low temperature impact does not cause a problem. Tests have been conducted on fiberglass reinforced polyester at $-40 \mathrm{~F}$, and the results showed almost a 508 increase in the dynamic load required to cause failure.

\section{IMPACT STRENGTH (SHATTER RESISTANCE)}

(Fig. 8)

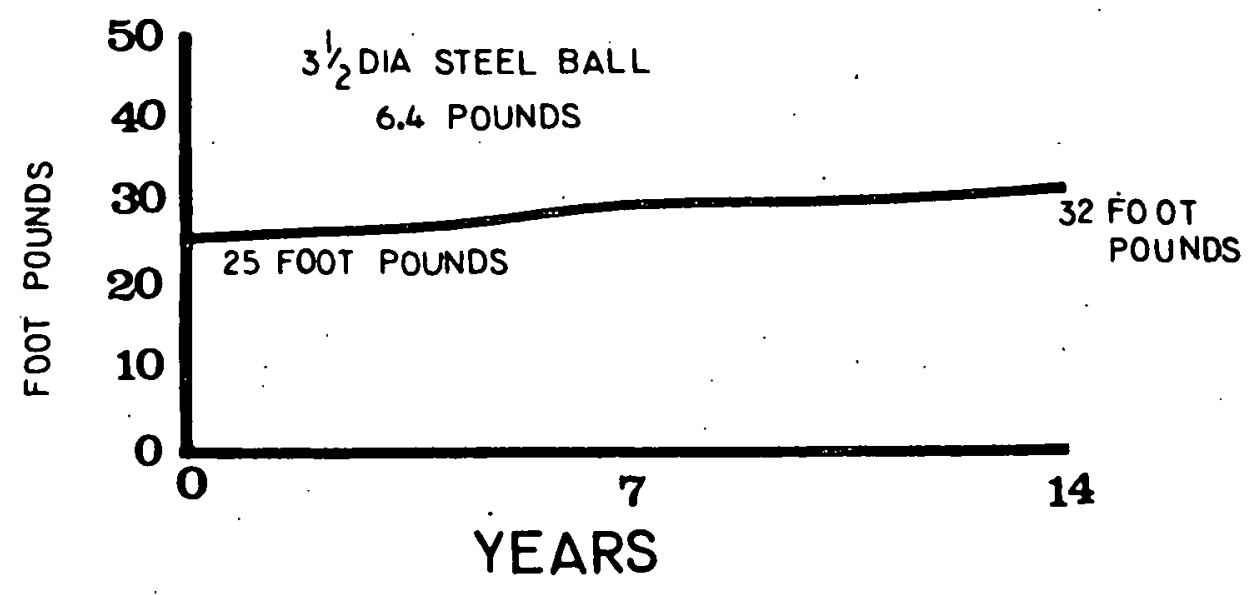


The final property to be considered for a solar collector cover to be able to withstand the effects of weathering is thermal shock. Many times during the life of a solar collector, a rain storm or other rapid change in temperature may cause a severe thermal shock to a heated collector. To test fiberglass reinforced polyester's resistance to thermal shock, a sample was heated to $300 \mathrm{~F}$ and then quickly submerged in cold water. The thermal shock did not cause any harmful effects or noticeable degradation.

\section{SUMMARY}

It has been shown that high grades of fiberglass reinforced polyester exhibit excellent weatherability. Critical properties for solar collector covers such as solar energy transmission, ultraviolet and thermal degradation resistance, erosion resistance, impact resistance, low temperatures, and thermal shock have been examined and shown to be highly acceptable fol. safe and efficient use in the solar industry.

Special thanks are extended to the American Cyanamid Company and Owens-Corning Fiberglas Corporation for their generous technical assistance and testing.

\section{BIOGRAPHY}

James S. White, Product Development Manager for Kalwall Corporation, one of the leaders in research and development of fiberglass reinforced plastics for over 25 years; has been involved in the development of special FRP products for the past 8 years, including the development of the accepted industry testing procedures for load/deflection, shatter resistance, and the visual rating system for weathered FRP.

Mr. White is a registered professional engineer and an active member of the Society of the Plastics Industries, the Soclety of Plastics Engineers, American Society for Testing and Materials, Solar Energy Industries Association, and the American Society of Heating, Refrigeration and Alr-Conditioning Engineers. 


\section{March 24, 1975}

To thow It May Concern:

The face sheets of Kalwall panels are inade of Orthophthalic !ulyoster rainforced !:i ih fiberglass. These are general purpose polyesters and coinpletely crossinked.

Polycster reinforced fiberglass sheets shrug off most harsh acids, alkalies and fumes. The enclo sed test report shous t!le specific reaction of polyester reinforced fiberglass sheets to fifty different cliemicals:

Jamc S. lihite

Tech ical Services 'anager

JS:4/.jr Enclosures 
RESISTANCE TO CHEMICAL REAGENTS

ASTM D $543 \cdot 67$

\section{Significance}

The limitations of the results obtairied from this test ihould be recognized.

The choice of $t$ pes and circentritions of reagents, duration of emersion, temperature of the test, and properties to be reported is necessarily arbitrary. Correlation of test results with actual performance or serviceability of plastics is dependent upon the similarity between the testing and in-use conditions. It should be noted that both :emperature and concentration have substintial effects on chemical resistance

\section{Procedure}

Specimens are emersed in the chemical reagents for seven days at room temperature. The reagents are stirred eve y 24 hours by moderate manual rotation of the containers. A visual exam:nation. is used to detect the effects of each of the chemical reagents.

\section{Test Specimens}

Three specimens $4^{\prime \prime} \times l^{\prime \prime}$ by varying thickne:;ses vere used for each matenial tested and for each reagent involied.

\section{Results}

See chart

\section{U.S. Testing Company}

Report No. LA 57135 
Chemical

Acetic Acid

(Glacial)

$F$

Acetic Acid 5\%

A

Acetone $C ; F ; K$

Ammonium Hydroxide 28\% $C ; D ; F$

Ammonium Hydroxide 10\% F

Aniline $x$

Benzene c

Carbon Tetrachloride A

Chromic Acid 40\% $B ; F$

Citric Acid 10\% A

Cottonseed. 0 il A

Detergent

Solution $1 / 4 \%$ A

Diethyl Ether C

Formamide $C: F ; G ; K$

Distilled Water $F ; K$

Ethyl Acetate $F$

Ethyl Alcohol

95\% F -

Ethyl Alcohol

50\% $\mathrm{F} ; \mathrm{K}$

Ethylene Dichloride $x$ Ethylhexyl Sebacate A 


\begin{tabular}{|c|c|}
\hline Chemical & Standar \\
\hline Heptanc & A \\
\hline $\begin{array}{l}\text { Hydrochloric } \\
\text { Acid } 37 \%\end{array}$ & $F ; K$ \\
\hline $\begin{array}{l}\text { Hydrochloric } \\
\text { Acid } 1.0 \%\end{array}$ & A \\
\hline $\begin{array}{l}\text { Hydrofluoric } \\
\text { Acid } 40 \%\end{array}$ & $C ; F ; H ; K$ \\
\hline $\begin{array}{l}\text { Hydrogen } \\
\text { Peroxide } 28 \% \\
\end{array}$ & A \\
\hline $\begin{array}{l}\text { Hydroyen } \\
\text { Peroxide 3\% }\end{array}$ & A \\
\hline Isooctane & A \\
\hline Kerosine & $A$ \\
\hline Methyl Al cohol & $F ; K$ \\
\hline Mineral & A \\
\hline Nitric Acid $70 \%$ & $D ; F ; K$ \\
\hline Nictric Acid $40 \%$ & A \\
\hline Nitric Acid 10\% & A \\
\hline Oleic Acid & A \\
\hline 0live $0 i 1$ & A \\
\hline Phenol 5\% & $F ; H:$ \\
\hline Soap Solution 1q & A \\
\hline $\begin{array}{l}\text { Sodium Car- } \\
\text { bonate } 20 \%\end{array}$ & A \\
\hline $\begin{array}{l}\text { Sodium Car- } \\
\text { bonate } 2 \% \\
\end{array}$ & A \\
\hline $\begin{array}{l}\text { Sodium Chloride } \\
10 \%\end{array}$ & A. \\
\hline
\end{tabular}
Legend: $\Lambda$ - No effect $\quad D$ - Yellowed $\quad G$ - Swelling $K$ - Blistered $B$ - Decreased opacity E - Stain H - Brittle X - Destroyed
C - Increased opacity F - Internal Fiberbloom J - Crazed


Sodium Hydroxide 60\% C

Sodium Hydroxide 10\% $C ; F$ Sodium Hydroxide 1\% A

Sodium $\mathrm{Hy}$ pochlorite $5 \%$

A

Sulfuric Acid

$97 \%$ $x$

Sulfuric lictd

$30 \%$

$B ; F$

Sulfuric Acid

$3 \%$

$C ; F$

Toluene

$C ; F ; K$

Transformer 0 oil

$F ; J ; K$

Turpentine

A

Legend: $\quad A-$ No effect

D - Yellowed

G. - Swelling K - Blistered

B - Decreased opacity

$E$ - Stain

$H$ - Brittle $X$ - Destroyed

C - Increased opacity F - Internal Fiberbloom J - Crazed 


\section{SPI \\ SHATTER RESISTANCE \\ BY THE FALLING BALL METHOD}

This test was conducted to determine the shatter resistance of fiberglass reinforced polyester panels. The test panels were mounted in a manner simulating use and a 3 1/2-inch diameter steel ball was used.

9.1.1 Method B of the SPI Shatter Resistance was followed.

9.1.2 There were five test specimens $16^{11} \times 16^{\prime \prime}$ of each type material. Type I material was clear and Type II material was clear:

9.1.2.1 No commercial designation. Company -- Kalwall Corporation--(D)

9.1.2.2 Type I material had an average thickness of .044 inches and an average weight of 5.0 ounces per square foot. Type II material had an average thickness of .061 inches and an average weight of 6.9 ounces per square foot. (See data sheet.)

9.1.4 The average distance the ball was dropped to produce failure for Type I material was 12 feet. The average distance the ball was dropped to produce failure for Type II material was 16.1/2 feet.

9.1.5 The average diameter of the hole for Type I material was approximately 5 inches. The average diameter of the hole for Type II material was approximately 5 inches. 
D A T.A SHEET

TEST: FALLING BALL

IMATERIAL : COMPANY D

\begin{tabular}{ccccc} 
Panel & Panel & Panel & Panel & Panel Avg. \\
1 & 2 & 3 & 4 & 5 \\
\hline
\end{tabular}

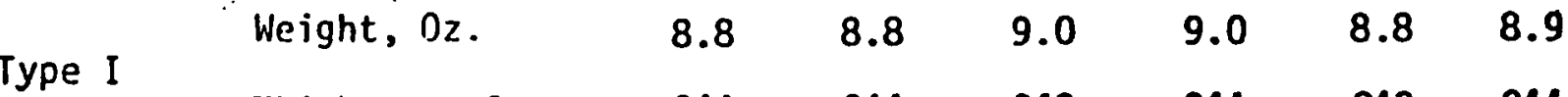
$\begin{array}{lllllll}\text { Thickness, In. } & .044 & .044 & .043 & .044 & .043 & .044\end{array}$

$\begin{array}{llllllll} & \text { Weight, 0z. } & 12.1 & 12.4 & 12.1 & 12.1 & 12.5 & 12.2 \\ \text { Type II } & \text { Thickness, In. } & .058 & .063 & .059 & .060 & .064 & .061\end{array}$

Type I Type II

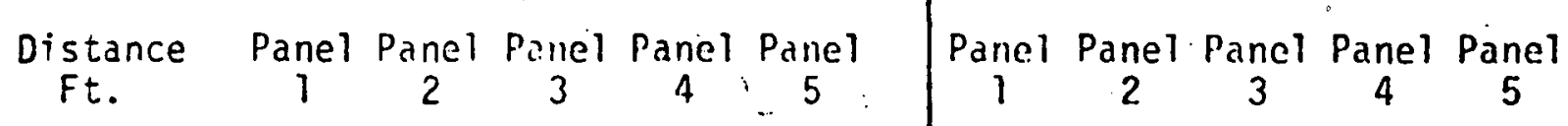

$20 \mathrm{~K}$

$2 \quad O K$

$3 \quad$ OK

4 OK

$5 \quad$ OK

$6 \quad$ OK

7 PULL PULL OK

8

OUT OUT OK

OK

9

10

11

12

13

OK

OK

OK

OK

OK

OK

OK

OK

RUP. OK
$5 "$

Long OK

PULL PULL

OUT OUT

14

15

16

17

FAIL

- Dia.

Avg.

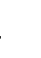

5

6

7 


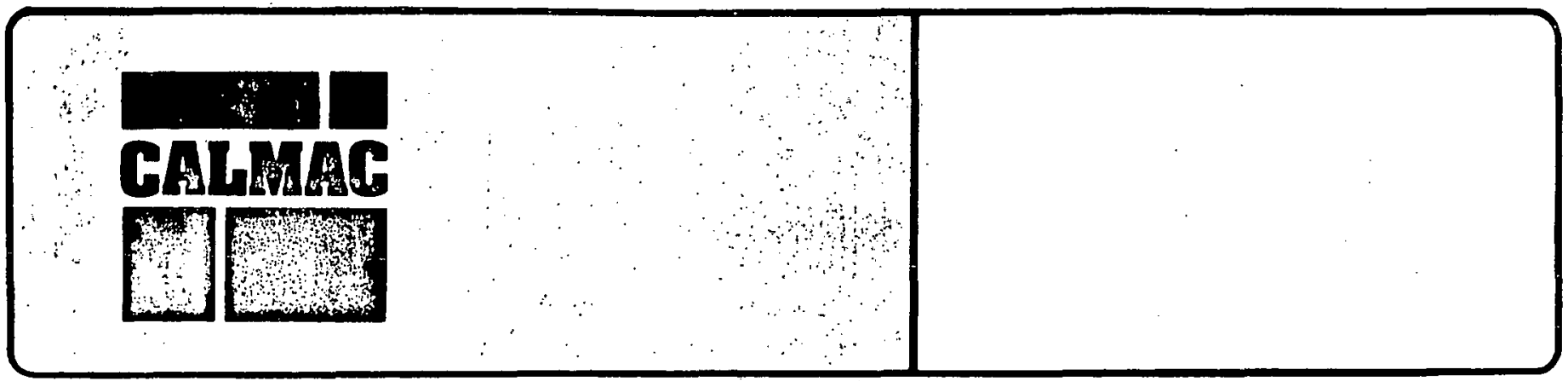

\section{CAL-ZORB 3968}

CAL-ZORB 3968 is a black, flexible, heat absorbing coating designed for use in solar heating equipment. It makes excellent bond to vinyl or vinyl containing materials such as ABS plastics. When catalyzed with CAL-ZORB 4562 its bond strength improves to a wide variety of substrates and its heat resistance is in excess of $200^{\circ} \mathrm{F}$.

\section{PHYSICAL CHARACTERISTICS}

1. Dires to a dull, black, tack-free heat absorbing coating.

2. High film strength.

3. Flexible through wide temperature extremes.

\section{TECHNICAL SPECIFICATION}

Base

BASE :

COLOR:

SOLVENTS :

SOLIDS:

VISCOSITY :

WE IGHT/GALLON :

SPECIFIC GRAVITY
Polyurethane

Black

MEK, MIBK, Toluene

$22.5 \%$

1800-2000 Cps, RVF Brookfield

\#5 Spindle e10 RPM

7. 39 Pounds

.886
Catalyst

Isocyanate

Clear

MEK Toluene

$55.75 \%$

$-$

8.76 Pounds

1.05

\section{PREPARATION OF SUBSTRATES:}

Surfaces should be free of dust and oil to obtain maximum bond strength. Solvent washing or abrading is recommended where feasible.

METHOD OF APPLICATION

Before using, mix thoroughly 10 parts of CAL-ZORB 3968 with 1 part of CAL-ZORB 4562 by volume. The blend should be stirred sufficiently long to insure a homogenous dispersion. The ratio of 3968 to 4562 can be varied to reduce the extent of cure and extend pot life and exact ratio is not critical. 
CAL-ZORB 4562

Page 2

Brush or coat the mixed system and allow to dry thoroughly. Drying is relatively slow to provide a bubble free film. Ultimate bond strength will be reached in approximately 24 hours, however, the bond or coating may be heated to affect a quick cure after solvent evaporation. Typical cycle is 30 minutes. $2200^{\circ} \mathrm{F}$.

CLEANING AND THINNER:

Methyl Ethyl Ketone

PRECAUTIONARY DATA:

These two products are extremely flammable. Vapors may cause flash fires. Vapors may ignite explosively under certain conditions. Keep away from fire, sparks, and sources of heat. Open all doors and windows. Extinguish all flames and pilot lights. Turn off electric motors, stoves, or heaters, or any source of ignition during use and until all vapors have been dispersed. Do not smoke. Close containers after use.

FLASH POINT: CAL-ZORB 3968- $22^{0} \mathrm{~F}$ T.C.C. CAL-ZORB $4562-22^{0}$ F T.C.C.

TOLERANCE LIMIT VALUE: 100 Parts per million in air.

USE WITH ADEQUATE VENTILATION

AVOID PROLONGED BREATHING OF VAPORS

AVOID PROLONGED AND REPEATED CONTACT WITH SKIN

KEEP OUT OF REACH OF CHILDREN

STORE AT TEMPERATURES OF $90^{\circ} \mathrm{F}$ OR BELOW FOR MAXIMUM SHELF LIFE 
APPENDIX B

Collector Installation, Operation and Service Manual 


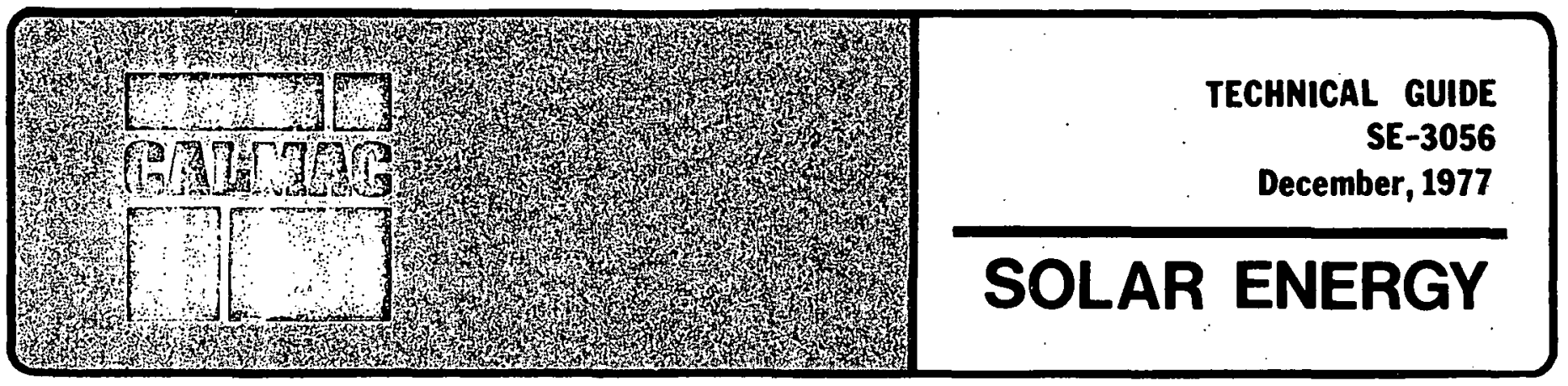

\section{SUNMAT Solar Collector}

\section{Installation, Operation and Service Manual}

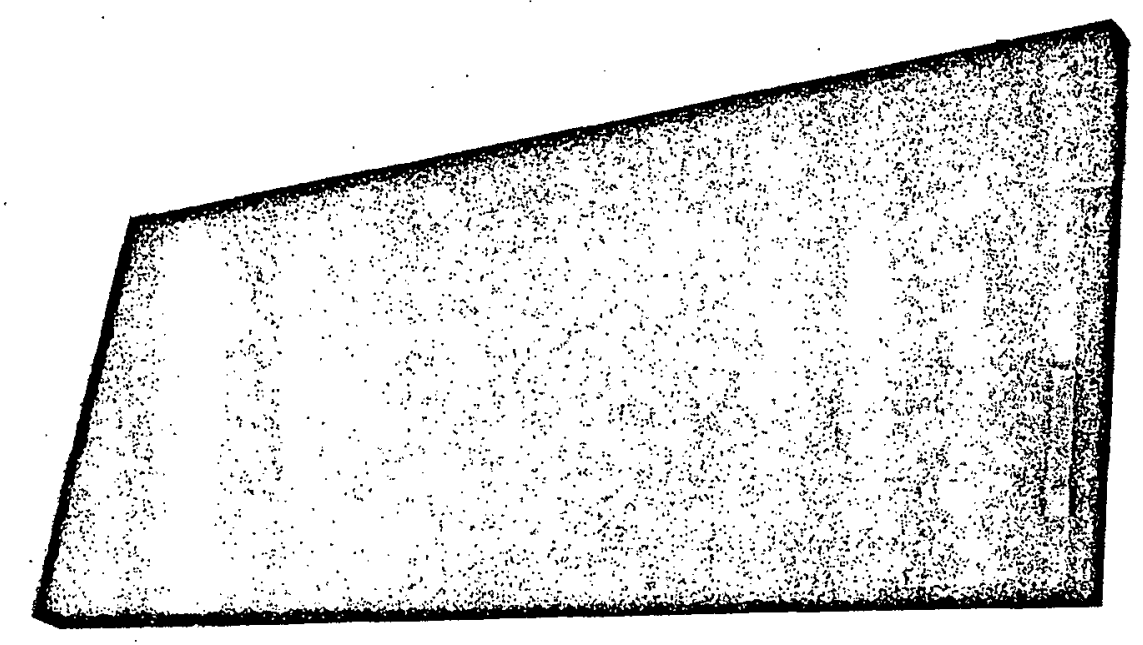

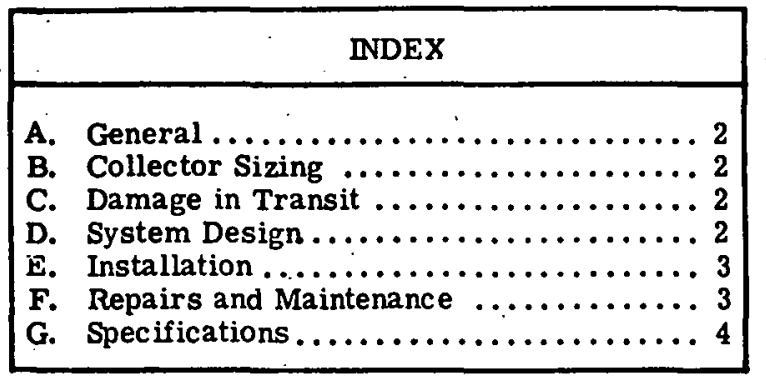

This Technical Guide is written to provide a complete and comprehensive procedure for the installation of the SUNMAT Solar Collector. It is not the intent of this guide to exclude sound and proven methods of installation by contractors who have, through experience and past performance, developed an efficient method of installation expertise.

ALL work must be performed in accordance with LOCAL, STATE and NATIONAL codes. 


\section{A. General}

1. The SUNMAT Solar Collector has been specially designed for space heating and other solar applications requiring large collector areas. The panels are custom-built to fit the dimensions of the roof $--\mathrm{a}$ feature that speeds installation and improves esthetics. The panels can also be built in very large sizes--up to $4^{\prime}$ by $25^{\prime}$. This means lower costs for plumbing and installation. The extensive use of synthetic materials makes them very lightweight and reduces corrosion problems. The special zipper lock feature allows easy access to the absorber in the event servicing is nec essary

\section{B. Collector Sizing}

1. The proper sizing of a collector systen is a complex process and a number of acceptable methods are available. For a proven, workable procedure refer to CALMAC Technical Guide SE-1223. The efficiency of the collector--a key input in the sizing calculations--is shown in Figure 1-1.

\section{Damage in Transit}

1. Upon receipt of shipment of this material, inspect all cartons for external damage. If external damage is noted, open the carton and inspect for damage to equipment. Mark the number of cartons received in this condition on the delivering carrier's waybill, and request the services of the inspector.

2. If upon opening a carton concealed damage is discovered, open the entire shipment and note all equipment so damaged. Contact the deliverinis carrier and request inspection of the damaged equipment. Do not destroy the carton as the inspector from the freight company will need this to determine the reason for damages.

\section{EFFICIENCY}

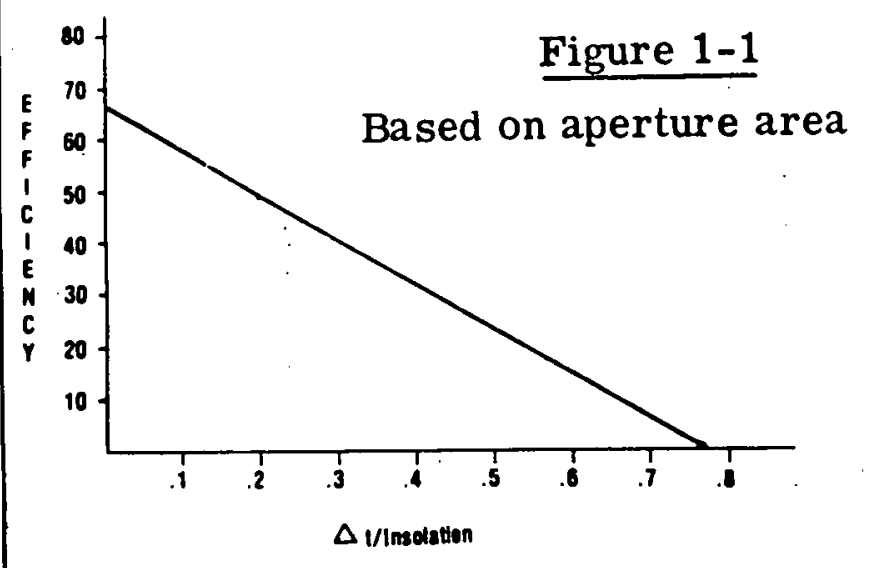

3. Normally, claims for any and all damages should be filed with the freight company within five working days after receipt of shipment.

4. Since all materials are sold $\mathrm{FOB}$ factory, it is the responsibility of the consignee to file claims with the delivering carrier for materials received in damaged condition.

\section{System Design}

1. Air Vent. An air vent should be installed at the highest point in the supply or return line in order to release air trapped in the piping.

2. Expansion Tank. An expansion tank is required in the supply or return line to allow for thermal expansion and contraction of the heat transfer fluid.

3. Pressure Drop. In sizing pumps for systems using water as the heat transfer fluid the pressure drop through the collector can be determined from Figure 1-3. For systems using anti-freeze heat transfer fluids, the pressure drops should be adjusted based on data provided by the supplier of the heat transfer fluid.

4. Relief Valves. A temperature relief valve set to open at $210^{\circ} \mathrm{F}$ and a pressure relief valve set to open at 20 PSI must be included in either the supply or return line. Ordinarily the pressure relief valve is located indoors and connected to a catch basin. The appearance of liquid in the catch basin provides evidence of a malfunction, and in closed loop systems the possible need to add more heat transfer fluid.

5. Strainers. A strainer should be installed in the supply line to the collector. This strainer should be checked one week after startup and annually thereafter.

6. Pressures and Flows. The maximum recommended operating pressure is 20 PSI. In practice this means that the collector should not be connected directly to a water main. Subjecting the system continuously to pressure above 20 PSI will cause the SUNMAT tubing to stretch over time and may lead to leaks in the system.

The minimum recommended flow rate throughaa collector is $2 \mathrm{GPM}$ to insure optimum efficiency. The maximum recommended flow rate through a collector is 5 GPM. Higher flows will create velocities through the headers which may cause whistling and/or erosion.

7. Gauges. In closed loop systems a pressure gauge reading the system pressure (usually 20 PSI) is recommended. A drop in system pressure usually indicates a leak in the system. 


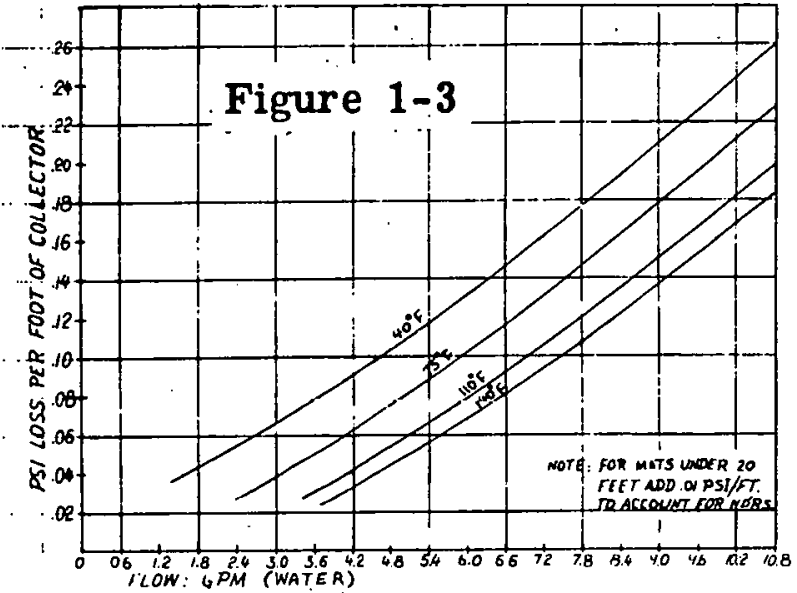

\section{E. Installing the SUNMAT Solar Collector}

1. The inlet and outlet plumbing connections to the SUNMAT collector are located at the same end of the collector. The $3 / 4$ " NPT connections are located either on the right or left side, both sides, or the back side of the collector. The configuratiun, which depends on where the pipes will best penetrate the roof, is specified at the time the order is placed with the factory.

2. The collector may be mounted vertically or horizontally with the plumbing connections at either the top or the bottom. Because the inside diameter of the collector tubing is small, trapped air is readily swept away when heat transfer fluid is circulated through the system, so the headers may be located at the bottom of a vertically mounted collector.
3. When two or more collectors are to be used side-by-side, it is permissible to make the inlet/outlet connections to one collector through one other collector. In this way four collectors can be hooked up to one supply and return line. See Figure 1-2.

4. For esthetic reasons care should be taken to insure that collector sides are parallel to adjacent roof lines. A chalk line is also helpful in getting the correct alignment. It is also helpful to have someone on the ground visually confirm the alignment:

5. If the roof structure underlayment is plywood and is in good condition, the collectors may be bolted to the plywood. The most secure connection is to bolt the collectors into the rafters. Holes in the collector mounting flange should be made to coincide with the location of the rafters. Holes in the flange shculd be $3 / 8^{\prime \prime}$ diameter. To allow for differential expansion they should also generally be elongated (up to l" for 25-foot long coll-ctors). To locate the rafters, use a stud finder or tap the roof with a hammer. The more solid sound indicates the rafter. Once the general location of the rafters has been determined, a nail can be driven through the roof to more precisely locate the rafters. These rafter location nails can be driven through a 2 " $\times 4$ " that will also serve as a temporary horizontal support at the bottom of the collectors while they are being bolted to the roof.

6. The collectors can now be brought up onto the roof. One way to bring the collectors onto the roof is to slide them up a ladder. With one person at the top of the ladder pulling and a second person pushing from below, the collector can be moved into place relatively easily.

7. Drill holes through the roof into the rafters. If $1 / 4$ " diameter lag bolts are used (min. recommended diameter) then the holes drilled into the roof should be several drill sizes smaller. After the holes are drilled into the rafter they should be filled with silicone sealant before the bolts are inserted. The bolts should be of sufficient length that they penetrate the plywood under layment, and engage a rafter by at least $2 "$.

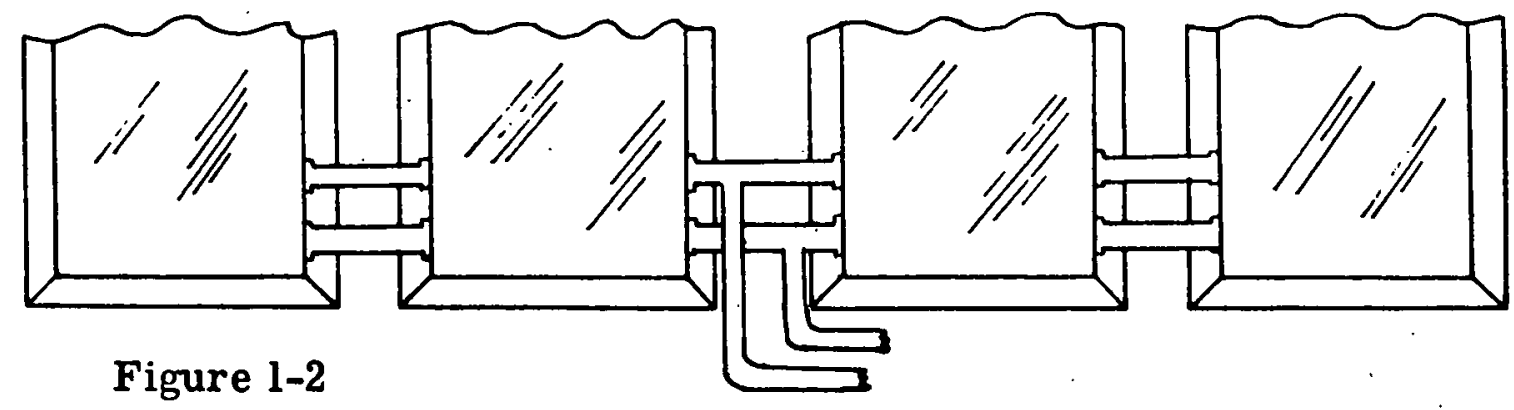


8. The collectors should be spaced a minimum of $1 / 4^{\prime \prime}$ apart so that thermal expansion and contraction of the frame does not disturb the mounting.

9. The manifold inlet and outlet connections are 3/4" NPT. Teflon tape is recommended as a sealant for all threaded connections. Do not insulate the piping or add flashing until the system is pressure-tested. Finding the leaks under flashing and insulation is quite difficult.

10. All roof penetrations should be sealed a second time to insure against leaks. Silicone sealant is a good choice.

11. Remove the nailer at the bottom of the collector that was used to hold the collectors on the roof and fill the nail holes with silicone sealant.

\section{F. REPAIRS AND MAINTENANCE}

1. No routine maintenance is required, but the system should be checked at least annually for breakdowns in the system.

2. Rain should keep the collector cover relatively dirt-free. However, if dirt or dust accumulates, it may be necessary to hose and wash the cover. Normal wind and water gradually abrade the cover panel, and to insure optimum performance every five to seven years the panel must be spray-coated with Kal-Lac, a fast-drying liquid applied by roller, spray or brush.

3. Any leaks that may develop in the tubing system can be repaired with copper splicer tubes and Stimpson clamps from the repair kit To make this type of repair a heavy, wide-bladed screwdriver should be used to pop the glazing frame piece off from the side wall. It is usually best to start at one corner. After the plastic zipper lock is undone, the cover can be rolled back to expose the tubing. To repair the tubing the damaged piece should be cut out and a splicer tube put in its place and fastened with Stimpson clamps at either end. Then the glazing should be repositioned in place and the side and top plastic frame pieces snapped back together with a rubber mallet starting at the corners and finishing midway between.

4. Because of the small diameter of the SUNMAT tubing, capillary action prevents complete draining of the tubing. In the event the collector must be completely drained, air pressure must be used to force fluid out of the tubing grid.

5. Every several years flushing the system may be advisable. Water run through the system at $40 \mathrm{PSI}$ is generally adequate. Connections for flushing should be included at the time of installation.

6. Heat Transfer Fluids. Heat transfer fluids should be maintained in accordance with specifications provided by the manufacturer. The SUNMAT system is compatible with glycol anti-freezes. Contact CALMAC before using other anti-freezes.

\section{SPECIFICATIONS}

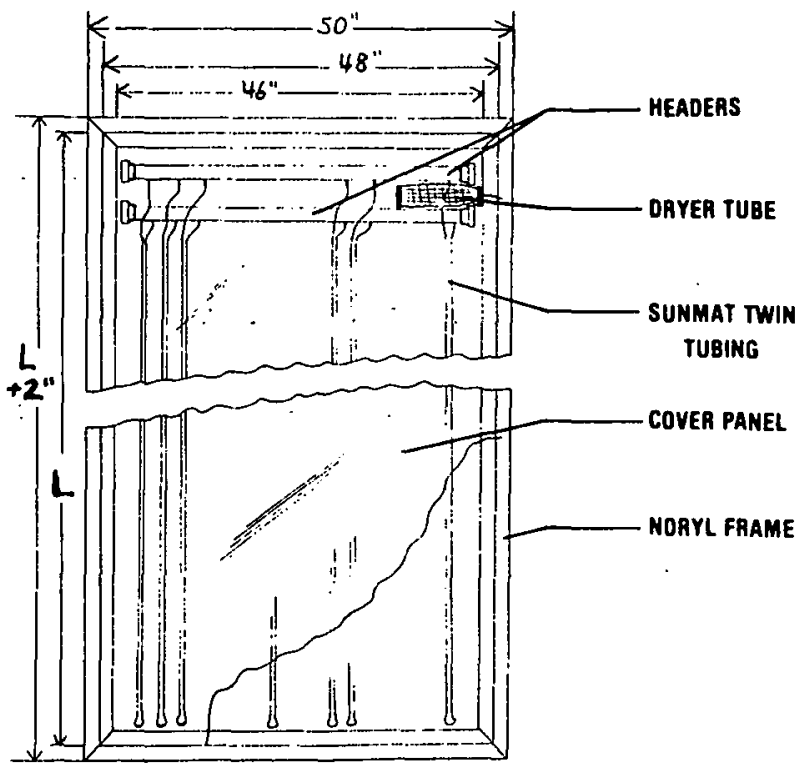

COVER PLATE:

Fiberglass-reinforced polyester, .040"

Transmissivity: $88 \%$ at $0^{\circ}, 78 \%$ at $45^{\circ}$

Wind Load Design: $100 \mathrm{MPH}$

ABSORBER:

Surface: Black, high temperature urethane coating

Aluminum Sheet: .002" thick

Tubing: 5/16" OD EPOM dual tubing

- Tube spacing $1 \frac{1 / 2}{2}$ " on center

- Manifold and outlet $3 / 4$ " OD type $L$ copper

-U-bends and manifold-to-tubing connections $1 / 4$ " copper

INSULATION:

High temperature $\left(350^{\circ} \mathrm{F}\right)$ rigid fiberglass

Density: $4.0 \mathrm{lbs} / \mathrm{ft}^{3}$

2" on bottom, $R=9 \quad 1^{\prime \prime}$ on sides, $R=4.5 @ 70^{\circ} \mathrm{F}$

DESICCANT:

Silica gel in 3/4" $\times 10 "$ wire mesh tube

COLLECTOR FRAME:

125" thick Noryl extrusion

MOUNTING PROVISIONS:

1 "flange around total perimeter

External plumbing connections $3 / 4$ " standard plpe thread

FLUID:

Capacity .03 gallons/ft'

MAXIMUM OPERATING TEMPERATURE: $210^{\circ} \mathrm{F}$

MAXIMUM ALLOWABLE TEMPERATURE: $300^{\circ} \mathrm{F}$

DESIGN LIFE OF COLLECTOR: 20 years

FLUID PRESSURES:

Maximum operating pressure: 20 PSI

Tubing test pressure: $80 \mathrm{PSI}$

FLOW RATES:

$.018 \mathrm{GPM} / \mathrm{square}$ foot of mat Minimum flow rate: $2.0 \mathrm{GPM}$

NOMINAL PRESSURE DROP:

$.16 \mathrm{PS}$ l per foot of length of mat 


\section{APPENDIX C}

Field-As sembled Solar Collector

Installation, Operation \& Service Manual 


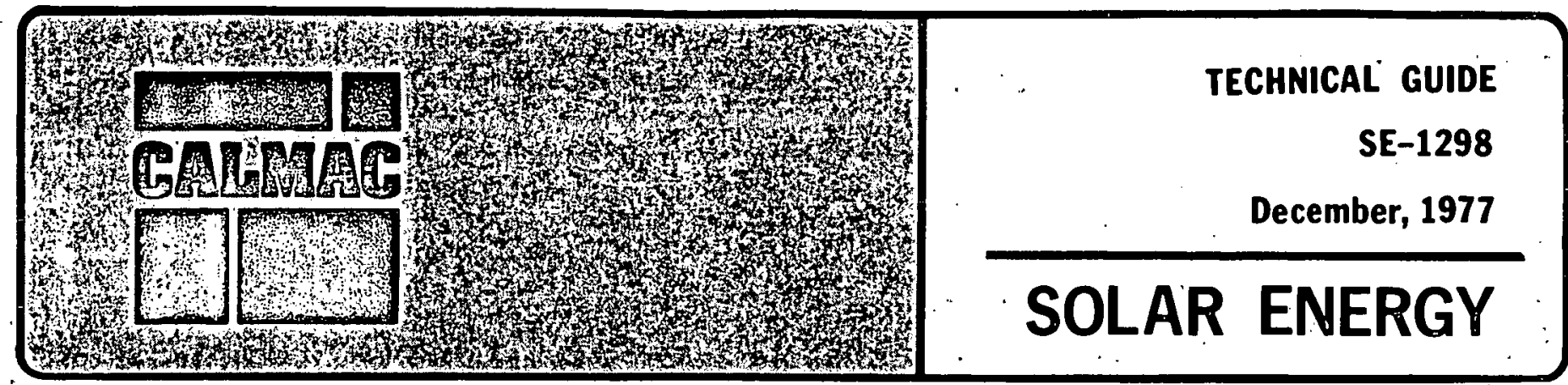

\section{SUNMAT Field-Assembled Solar Collector}

\section{Installation, Operation \& Service Manual}

\begin{tabular}{|c|c|}
\hline & INDEX \\
\hline & 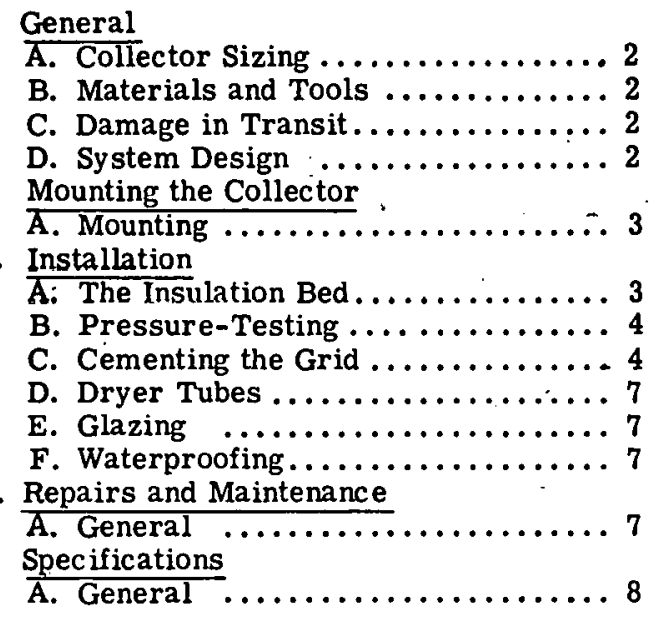 \\
\hline
\end{tabular}

The SUNMAT Field-Assembled Solar Collector System is a non-metallic single-glazed collector designed to be constructed on site in much larger sizes than conventional factory-assembled panels. The system allows the collector to be tailored to fit the dimensions of any installation and provides economies of scale in construction and plumbing.

The SUNMAT consists of a flexible grid of 30 closely spaced elastomer twin tubes cemented to an insulation board base and covered with a flexible reinforced plastic cover. The grid substitutes for the metal absorber plate used in conventional panel-type collectors.

ALL aspects of this installation must comply with NATIONAL, STATE and LOCAL codes.

The information in this manual has been prepared to save time, obtain the best possible installation and insure continuous trouble-free operation of the collector system.

All materials obtained locally or from suppliers other than CALMAC Manufacturing Corporation must be in accordance with specifications set forth in the Section on Specifications. 


\section{GENERAL}

\section{A. Collector Sizing}

The proper sizing of a collector system is a complex process and a number of acceptable methods are available. For a proven, workable procedure refer to CALMAC Technical Guide SE-1223. The efficiency of the collector--a key input in the sizing calculations-is shown in Figure.1.

\section{B. Materials and Tools}

1. The following materials are required to build the collector:
Item

Absorber tubing system (EPDM tubing grid with copper U-bends and headers)

Absorber cement

Plastic Cover Panel

Contact Cement

Insulation Cement

EPDM Hose

Roofing Mastic

Condensation Dryers

Foil-Faced Tape

For further specification on the materials refer to the Specifications Section.

2. The following tools are required to build the collector:

12" adjustable wrench

12" pipe wrench

knife

pair of hand gloves

bicycle pump or other source of

compressed air

pair of pliers

measuring tape

straight edge

masking tape or fraction thereof
Insulation Board

\author{
Quantity \\ 4 ' $x$ desired length
}

One gallon for every 40 square feet

$4^{\prime} \mathrm{x}$ desired length

$220 \%$ of collector area

One gallon for every 130 square feet

One gallon for every 60 square feet

$1 / 2$ " per square foot of collector

One gallon for every square feet

One for every 200 square feet of collector

Four feèt for every four feet of collector length

\section{Damage in Transit}

1. Upon receipt of shipment of this material, inspect all cartons for external damage. If external damage is noted, open the carton and inspect for damage to equipment. Mark the number of cartons received in this condition on the delivering carrier's waybill, and request the services of the inspector.

2. If upon opening a carton concealed damage is discovered, open the entire shipment and note all equipment so damaged. Contact the delivering carrier and request inspection of the damaged equipment. Do not destroy the carton as the inspector from the freight company will need this to determine the reason for damages.

3. Normally, claims for any and all damages should be filed with the freight company within five working days after receipt of shipment.

4. Since all materials are sold FOB factory, it is the responsibility of the consignee to file claims with the delivering carrier for materials received in damaged condition.

\section{System Design}

1. Headering. When two or more collectors are to be used and assembled side by side, it is permissible to connect the header system of one collector to the in and out piping through one other header system. Using a $T$-connection it is possible to hook four header systems to the same in and out piping. See Figure 2. 


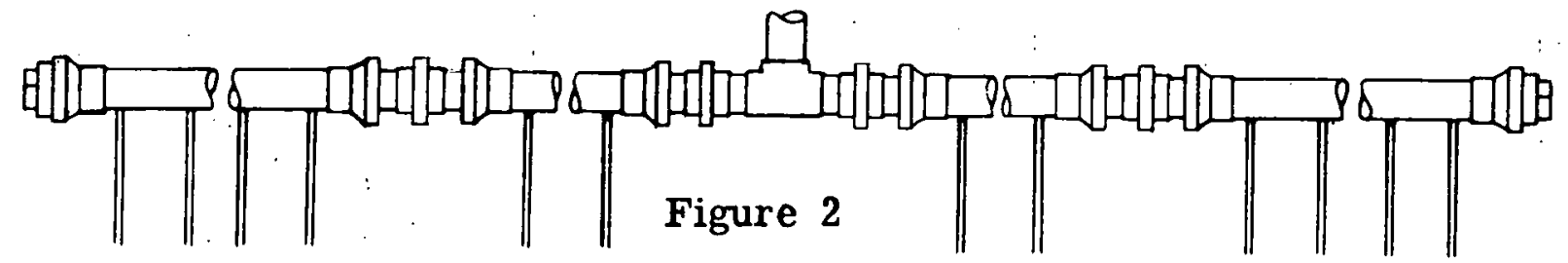

2. Air Vent. An air vént should be installed at the highest point in the supply or return line in order to release air trapped in the piping.

3. Expansion Tank. An expansion tank is required in the supply or return line to allow for thermal expansion and contraction of the heat transfer fluid.

3. Pressure Drop. In sizing pumps for systems using water as the heat transfer fluid the pressure drop through the collector can be determined from Figure 3. For systems using anti-freeze heat transfer fluids, the pressure drops should be adjusted based on data provided by the supplier of the heat transfer fluid.

4. Relief Valves. A temperature relief valve set to open at $210^{\circ} \mathrm{F}$ and a pressure relief valve set to open at 20 PSI must be included in either the supply or return line. Ordinarily the pressure relief valve is located indoors and connected to a catch basin. The appearance of liquid in the catch bisin provides evidence of a malfunction, and in closed loop systems the possible need to add more heat transfer fluid.

5. Strainers. A strainer should be installed in the supply line to the collector. This strainer should be checked one week after startup and annually thereafter.

6. Pressures and Flows. The maximum recommended operating pressure is 20 PSI. In practice this means that the collector should not be connected directly to a water main. Subjecting the system continuously to pressure above 20 PSI will cause the SUNMAT tubing to stretch over time and may lead to leaks in the system.

The minimum recommended flow rate throughaa collector is 2 GPM to insure optimum efficiency. The maximum recommended flow rate through a collector is 5 GPM. Higher flows will create velocities through the headers which may cause whistling and/or erosion.

7. Gauges. In closed loop systems a pressure gauge reading the system pressure (usually 20 PSI) is recommended. A drop in system pressure usually indicates a leak in the system.

\section{MOUNTING THE COLLECTOR}

\section{A. Mounting the Collector}

1. When the system is built on a steeply slanting roof, a scaffolding should always be used. A scaffolding makes the installation much easier and is the safest method.

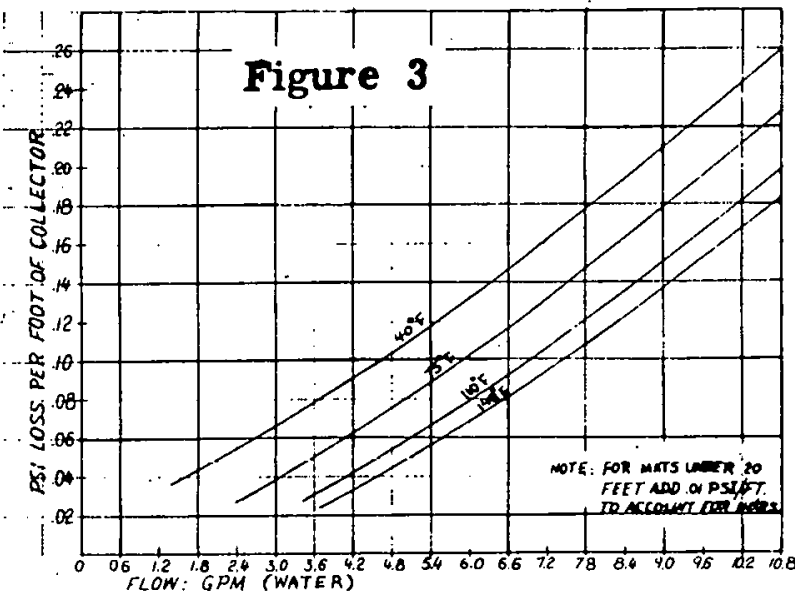

2. The surface on which the SUNMAT system is to be built must be sturdy and flat. As a rule, any normal roofing surface is acceptable as long as the fiberglass insulation which forms the collector bed can be bonded firmly to it with roofing mastic. Since the SUNMAT is quite lightweight, installation on an existing roof does not add appreciably to the load on the roof and is usually quite safe.

3. The layout of the collector installation must take into consideration the size and shape of the space available for the collectors. Each grid of the SUNMAT system is $4^{\prime}$ wide. The length of the SUNMAT collector can be any size up to $50^{\prime}$ and is therefore cut to fit the available space. In laying out the length, however, it is important to keep in mind that an additional 4" must be allowed beyond the desired length of the absorber system for connecting the headers and U-bends. It is also advisable to keep the length of the SUNMAT as long as practicable since this reduces the cost per square foot.

4. The collectors should not be mounted absolutely horizontal since in this position water will pond on the glazing and dirt will accumulate. The minimum recommended slope is 1 in 12 .

\section{INSTALLATION}

\section{A. Constructing the Insulation Bed}

1. Cut and build the bed of insulation board. This bed is made of $l$ " thick foil-faced fiberglass insulation boards cemented face to face. The bottom boards are 2 ' $\times 4^{\prime}$ '. The top boards are 4' $x 10^{\prime}$ boards that have been factory-outgassed at $350^{\circ} \mathrm{F}$ for an hour. l" must be trimmed off these boards to allow for the perimeter walls. 


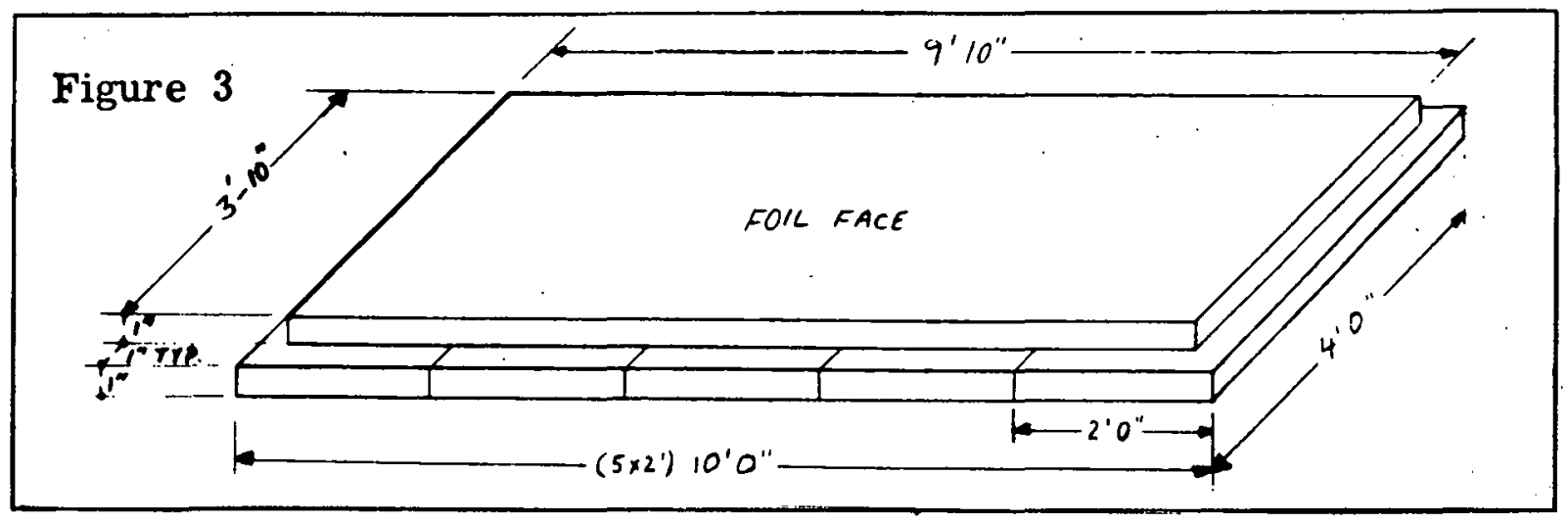

The boards must also be trimmed to the proper length, which is a function of the size of the collector. The top board must be 2 " shorter than the bottom board--again, to allow for the perimeter walls. The unfaced sides of the boards are cemented together using the insulation cement to make a 2 " board foil-faced on both sides. In order to make one unified section the top and bottom boards are overlapped. The top boards are centered on the bottom board to allow for the perimeter walls. See Figure 3.

\section{Cut and cement the fiberglass} insulation perimeter strips to the bed. This wall provides the surface to which the cover panel is cemented. The strips are $21 / 2^{\prime \prime}$ wide. The length depends on the size of the collector. Contact cement is used to adhere the strips to the insulation bed. See Figure 4.

3. Mount the insulation loard bed on its supporting surface. The bed can be affixed directly to smooth supporting surfaces with ordinary roofing mastic. On surfaces that are irregular, such as shingled roofs, laying down a plywood frame and adhering the bed to the frame with roofing mastic is recommended.

\section{B. Pressure-Testing the SUNMAT for Leaks}

1. Pressure-test the tubing system for leaks using a portable air compressor, bicycle pump or canister of compressed air to pressurize the tubing to $40 \mathrm{PSI}$. One of the headers is supplied with a tank valve to facilitate testing for leaks.

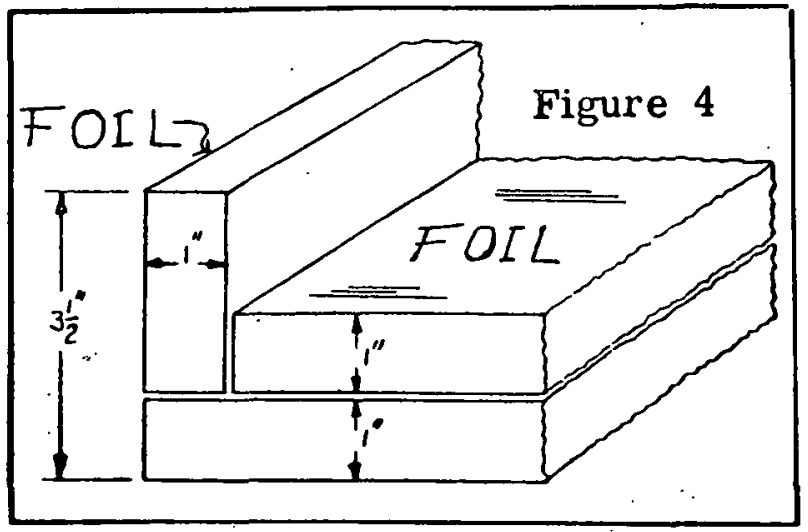

Any leaks should make a hissing sound. Leaks are rare and are usually caused by improper connections between the SUNMAT tubing and the $\mathrm{U}$-bends or headers. Leaks can be detected by applying soapy water and looking for bubbles. Leaks can be repaired by adjusting or replacing the Stimpson clamps. The tubing itself does not renerally leak unless it has been damaged in shipment or handling. Leaks in the tubi ig are repaired with splicers from the repair kit in accordance with instructions in the section on Repairs and Maintenance.

\section{Cementing the SUNMAT Grid to the Insulation Bed}

1. Position the SUNMAT grid in place. The header end of the mat should be butted against the end border of the bed. If the mat is fairly short, it can be placed directly on the insulation. If it is long, it may be easier to roll it off the shipping roll and onto the insulation bed. The header and $U$-bend ends of the mat should be secured in place with a piece of foil-faced tape pressed down between each tube onto the foilfaced insulation board. Similarly, foil-faced tape should be used to hold the mat itself in place every four feet. See Figure 5 .

2. Put three spacer blocks in place 12 " apart every two feet. These blocks are made of $11 / 2$ " lengths of l" EPDM hose. They are set in place between slightly spread tubes and held in place by the absorber cement (next step). See Figure 6.

3. Spray or brush the two-part absorber cement over the entire surface until the aluminum foil is completely blacked out. To insure a good bond the joint where the tubes and foil meet must be filled with adhesive. In mixing the two-part cement, directions on the can should be followed carefully.

4. At the side of the collector where the external plumbing connections are to be made, passageways for the connections should be cut through the perimeter strips and pipe nipples for the connections should be cut through the perimeter strips and pipe nipples extending through the perimeter wall should be installed. At this point in the construction process it is usually advantageous to hook up the sensor that measures the outlet temperature for the differential thermostat and any other valves or vents indicated. See Figure 7. 


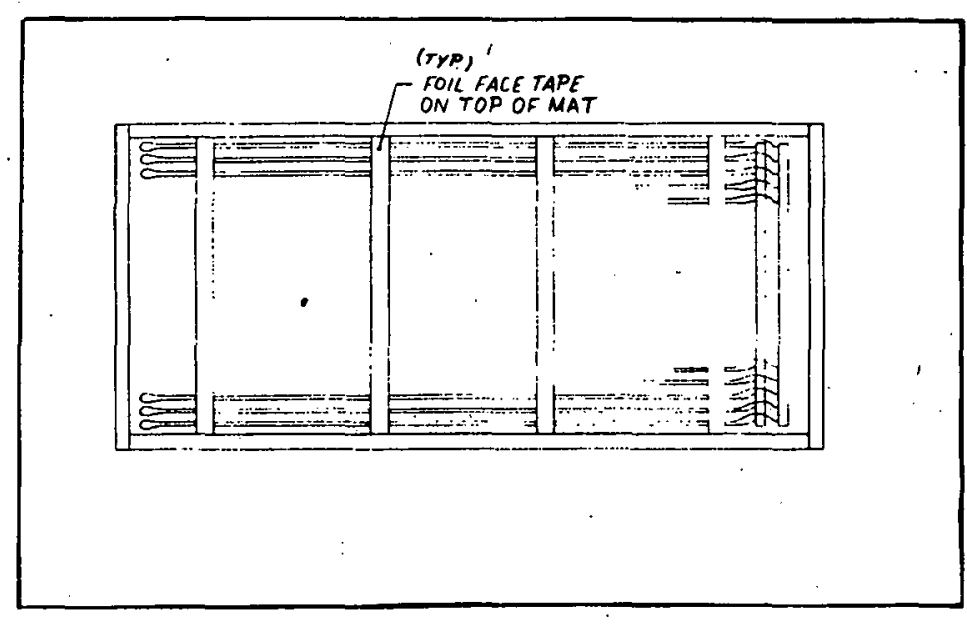

Figure 5

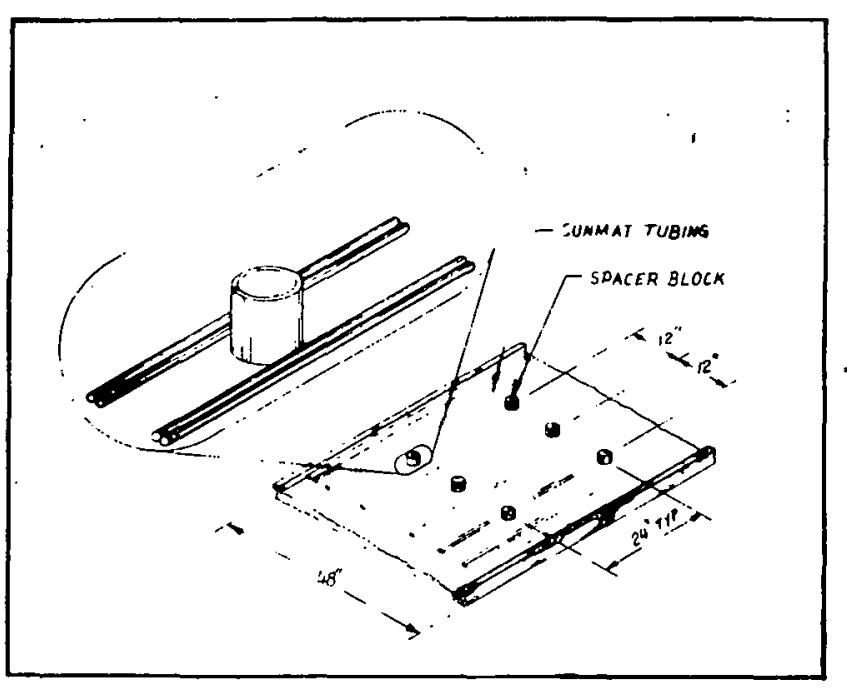

Figure 6

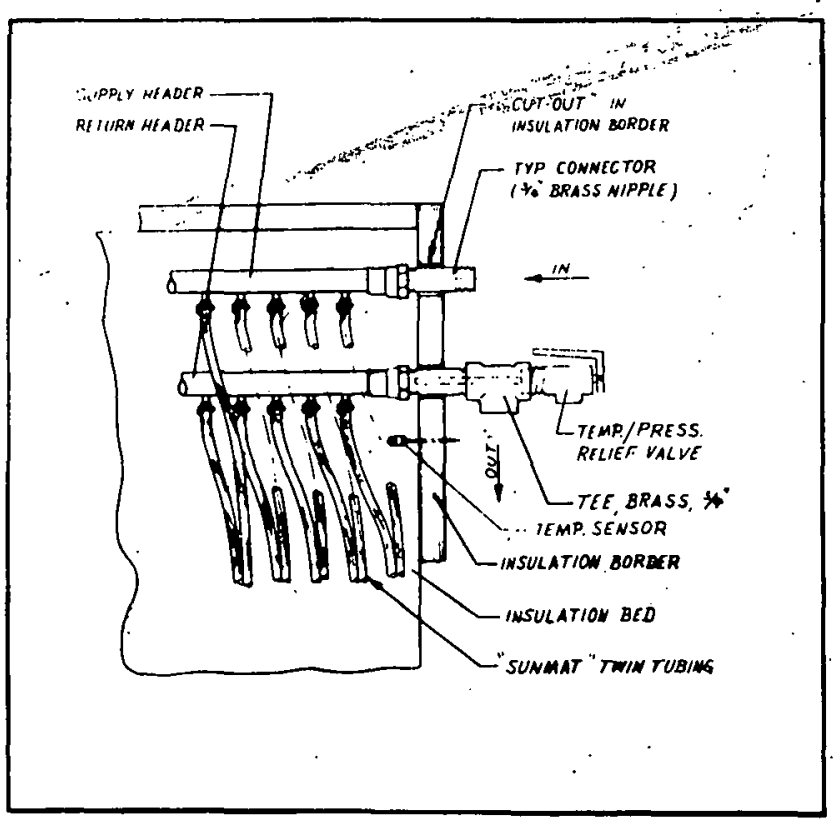

Figure 7

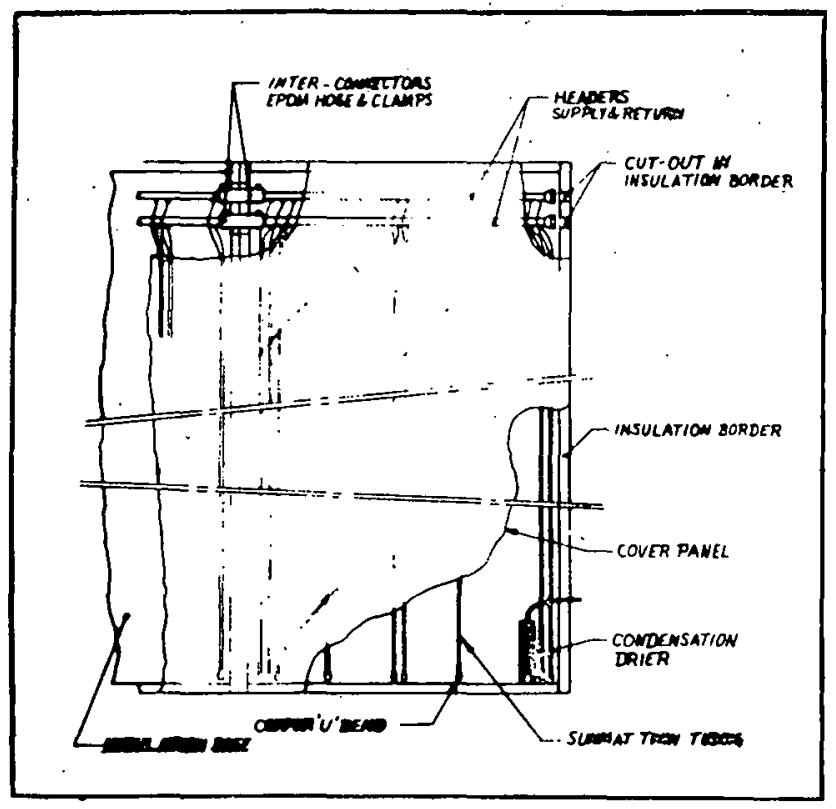

Figure 8 


\section{Dryer Tubes}

1. Install one dryer tube for every 200 square feet of collector or fraction thereof. Dryer tubes are used to prevent the build-up of moisture condensation under the collector glazing. The dryer tube is installed along the outside perimeter by punching an outlet in the border strip with a screwdriver. See Figure 8.

\section{E. Installing the Plastic Glazing}

1. Apply a coat of contact cement to the top edge of the perimeter strip. Start from one end, then move to the sides and down the borders toward the opposite end, catching the spacer blocks as well. If the length of the collector is less than 12 feet, the contact cement can be applied in one step but if the length exceeds 12 feet, more than one step may be necessary since the cement dries quickly.

2. Place the end of the rolled up plastic glazing over the end of the collector coated first, and unroll the glazing. The glazing should be unrolled gradually, making sure that it is running square to the border. After it is completely unrolled, press it lightly against the border and spacer blocks to insure good bonding.

\section{F. Waterproofing the Complete Collector}

L. Waterproof the entire system by applying roofing mastic to all the exposed insulation, and to the l" edge of the plastic glazing that overlaps the insulation board perimeter. Cement should be used liberally to make a sical around the header pipes and dryer tube where they come through the insulation board. Use masking tape on the glazing so as to make a straight edge between mastic and glazing.

\section{REPAIRS AND MAINTENANCE}

\section{A. General}

1. No routine maintenance is required, but the collector should be checked at least annually for breakdowns in the system.

2. Rain should keep the collector cover relatively dirt-free. However, if dirt or dust accumulates, it may be necessary to hose and wash the cover. Normal wind and water gradually abrade the cover panel, and to insure optimum performance every five to seven years the panel must be spray-coated with Kal-Lac, a fast-drying liquid applied by roller, spray or brush.

3. Over time cracks may develop in the waterproofing, particularly in areas where the roofini mastic was put on too thin. These cracks can be easily repaired with fresh mastic.
4. Any leaks that may develop in the tubing system can be repaired with copper splicer tubes and Stimpson clamps from the repair kit. To make this type of repair a knife should be used to cut through the fiberglass border strips. After the cut is made, the cover can be lifted to expose the tubing. To repair the tubing the damaged piece should be cut out and a splicer tube put in its place and fastened with Stimpson clamps at either end. See Figure 11. Contact cement can then be used to cement the fiberglass back together. Finally a new coat of mastic should be applied to seal the collector.

5. Because of the small diameter of the SUNMAT tubing, capillary action prevents easy draining of the tubing. In the event the collector must be completely drained, air pressure must be used to force fluid out of the tubing grid.

6. Every several years flushing of the system may be advisable. Water run through the system at 40 PSI is generally adequate. Connections for flushing should be included at the time of installation.

7. Heat Transfer Fluids. Heat transfer fluids should be maintained in accordance with specifications provided by the manufacturer. The SUNMAT system is compatible with glycol anti-freezes. Contact CALMAC before using other anti-freezes.

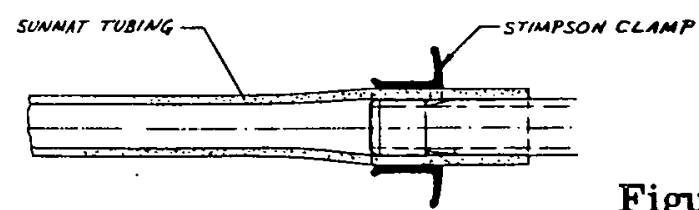

Figure ll 

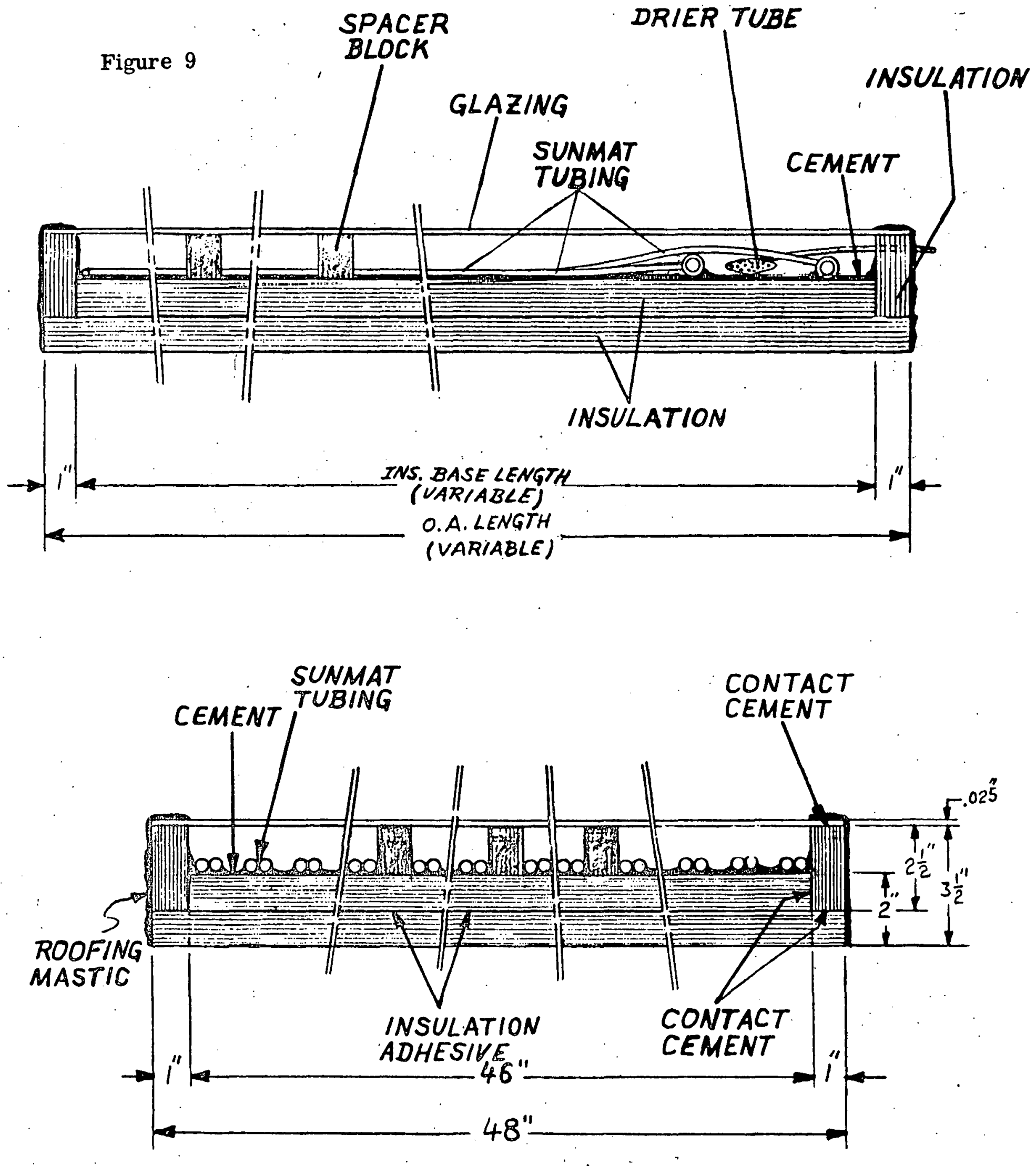

Figure 10 


\section{SPECIFICATIONS}

\section{PHYSICAL DATA:}

Width: 4'

Length: Up to $50^{\prime}$

Depth: $31 / 2$ "

Weight (unfilled): 2.0 pounds $/ \mathrm{ft}^{2}$

Coolant Weight: .2 pounds $/ \mathrm{ft}^{2}$

\section{MATERIALS:}

Gla zing: .025" guage fiberglass-reinforced polyester. $88 \%$ solar transmittance at $0^{\circ}$, $78 \%$ at $45^{\circ}$. Kalwall SUN-LITE Premium II or equivalent.

Absorber: 5/16" OD, 3/16" ID EPDM dual tubing spaced $11 / 2$ " on center bonded to insulation board with CAL-ZORB urethane cement. One gallon covers 40 square feet.

Headers: 3/4" X 42 1/2" type L copper pipe. External connections are 3/4" threaded pipe connections soldered to the pipe. Connections to the absorber tubing are $1 / 4$ " nipples soldered to the pipe every $13 / 8^{\prime \prime}$. Two headers per mat.

Desiccant: Silica gel in aluminum wire mesh tube. One dryer required for every 200 square feet of collector or fraction thereof.

Insulation: Fiberglass duct board, high temperature $(3500 F)$, three pounds per cubic foot density, foil-faced, l" thick. Owens-Corning Fiberglass 703 or equivalent.

Adhesives: Contact cement used to bond cover panel and perimeter walls to insulation bed, 3M 1300 Rubber Adhesive or equivalent. One gallon for every 130 square feet of collectur. Adhesive used to waterproof the collector, roofing mastic. Adhesive used to bond insulation together, Foster 85-15 Stic-Safe Adhesive.

Coolant: Water or mixture of glycol and water. .03 gallons per square foot.

\section{OPERATING DATA:}

Flow Rates: .018 GPM per square foot of mat, minimum of $2.0 \mathrm{GPM}$.

Pressure Drop: . 16 PSI per foot of length of mat, water. .2 PSI per foot of length of mat, $40 \%$ ethylene glycol at $100^{\circ} \mathrm{F}$.

Temperature: Maximum operating temperature, $210^{\circ} \mathrm{F}$. Maximum allowable tubing temperature, $350^{\circ} \mathrm{F}$.

Fluid Pressure: Maximum operating pressure, 20PSL Tubing burst pressure, 80PSI.

$\mathrm{F}_{\mathrm{R}} \mathrm{U}_{\mathrm{L}}: \cdot .86$

$\mathrm{F}_{\mathrm{R}}(\mathrm{Ta})_{\mathrm{n}}: .67$ 